PLEASE dO NOT DESTROY OR THROW AWAY THIS PUBLICATION. If you hate no further use for it, write to the Geological Survey at Washington and ask for a frank to returalt

UNITED STATES DEPARTMENT OF THE INTERIOR

\title{
THE BOOK CLIFFS COAL FIELD IN GARFIELD AND MESA COUNTIES COLORADO
}

GEOLOGICAL SURVEY BULLETIN 851

QE 75

126

110.851 
UNITED STATES DEPARTMENT OF THE INTERIOR

Harold L. Ickes, Secretary

GEOLOGICAL SURVEY

W. C. Mendenhall, Director

Bulletin 851

\title{
THEBBOOK GLIFFS COAL FIELD IN \\ GARFIELD AND MESA COUNTIES GOLORADO
}

\author{
BY \\ CHARLES E. ERDMANN
}

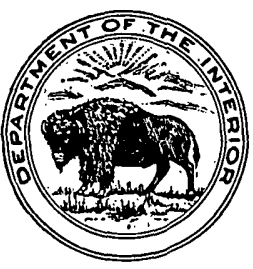

UNITED STATES

GOVERNMENT PRINTING OFFICE

WASHINGTON : 1934

or sale by the Superintendent of Documents, Washington, D.C. - - - - - Price 35 cents 


\section{CONTENTS}

Page

Abstract

Introduction

Location and extent.

Accessibility ... 3

Condition of land surveys. 4

Previous geologic investigations.... 5

Present investigation

Acknowledgments

Geography _... 10

Geomorphology

Grand Valley...... 11

Book Cliffs........... 13

Plateau between the Book and Roan Cliffs

Roan Cliffs.......... 16

Roan Plateau. 16

Drainage and water supply

Climate...

Vegetation

Culture._... 20

Stratigraphy

General features

Concealed rocks............. 24

Pre-Cambrian.

Upper Triassic

Chinle formation

Jurassic (?) and Upper Jurassic rocks

Cretaceous (?) system _. 26

Morrison formation. 26

Cretaceous system

Dakota (?) sandstone..... 27

Exposed rocks

Cretaceous system

Upper Cretaceous series.

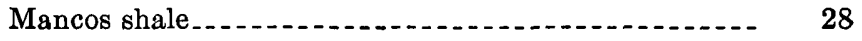

Mesaverde group 31

General relations...... 31

Sego sandstone.

Lower member of Sego sandstone.

Anchor Mine tongue of Mancos shale...... 36

Upper member of Sego sandstone......... 38

Mount Garfield formation.................. 40

Lower part, or "coal measures" 41

Upper part, or "barren measures"......... 44

Relations of Mount Garfield formation to

Bowie and Paonia shale members of Grand

Mesa field............................. 44

Type section _....... 45

Hunter Canyon formation............ 48 
Stratigraphy-Continued.

Exposed rocks-Continued. Page

Tertiary (?) sandstone... 53

Tertiary system... 55

Eocene series.

Wasatch formation....... 55

Green River formation.... 57

Quaternary system .............. 59

Terrace gravel_......... 59

Recent alluvium........ 60

Structure

Regional setting 60

Structural history 62

Representation of structure.... 64

Local structure... 65

Monoclines... 65

Folds_... 66

Garmesa anticline........... 67

High Line dome....... 68

Faults_._.

Natural gas _....... 69

Development_...... 69

Garmesa dome. 69

Book Cliffs dome..... 72

Camp Canyon dome.... 72

Carbonera dome. 72

Correlation of the gas sands

Production.

Character.

Coal deposits

General occurrence. 76

Names and intervals of coal zones... 78

Relations of coal zones to sandstones 78

Conditions of deposition

Coal zones.

Anchor coal zone.... 80

Palisade coal zone... 81

Cameo coal zone......... 83

Carbonera coal zone..... 86

Burning of coal beds..... 86

Chemical composition of the coal

Quantity of coal _. 92

Mining development and production of coal

Suggestions for prospecting 107

Township descriptions _. 109

T. 11 S., R. 98 W. 109

T. 11 S., R. 99 W.

T. 10 S., R. 98 W. 112

T. 10 S., R. 99 W. 113

T. 1 N., R. 1 E. 117

T. 10 S., R. 100 W. 120

T. 9 S., R. 100 W. 121

T. 9 S., R. 101 W.

T. 8 S., R. 101 W. 124 
Township descriptions-Continued. Page

T. 8 S., R. 102 W. 127

T. 8 S., R. 103 W._. 132

T. 8 S., R. 104 W. 133

T. 7 S., R. 102 W.

T. 7 S., R. 103 W. 136

T. 7 S., R. 104 W. 137

T. 6 S., R. 103 W. 142

T. 6 S., R. 104 W. 143

Tps. 7 and 8 S., R. 105 W.

Index....

\section{ILLUSTRATIONS}

Prate 1. Geologic map and structure sections of the Book Cliffs coal field in Colorado.......... In pocket

2. $A$, Profile of Book Cliffs on south face of Mount Garfield; $B$, View westward from northwest corner of T. 11 S., R. 98 W.-

3. $A$, Profile of Book Cliffs east of mouth of Hunter Canyon; $B$, Beheaded remnant of high terrace standing on lower terrace plain at foot of Book Cliffs

4. Upper Cretaceous stratigraphy in Book Cliffs coal field _. .... 26

5. Mesozoic stratigraphy in Book Cliffs coal field........... 26

6. $A$, Indurated sand and gravel capping lower destructional terrace carved on Mancos shale; $B$, Sego sandstone on east wall of mouth of East Salt Creek Canyon . ...............

7. $A$, Type section of Mount Garfield formation on west wall of canyon at Book Cliff mine; $B$, Outcrop of Anchor coal on cliff face in sec. 13, T. 8 S., R. 102 W. . . . . . . . . .

8. $A$, Valley of West Salt Creek between Carbonera and Atchee; $B$, Massive sandstone of Hunter Canyon formation........

9. $A$, Normal fault forming the east side of the graben through which West Salt Creek flows; $B$, Erosional unconformity and conglomerate at base of Tertiary (") sandstone............

10. A, View northward up Hunter Canyon from point 1,200 feet above Hidden Treasure mine; $B$, Outcrop of Tertiary (?) sandstone and Wasatch and Green River formations on Roan Cliffs at head of Hunter Canyon............

11. Structure contour map of Book Cliffs coal field .........

12. Diagrammatic sections of coal zones in Book Cliffs field......

13. Comparative statistics of coal production................

14. $A$, Surface plant at Williams mine; $B$, Outcrop of Cameo coal

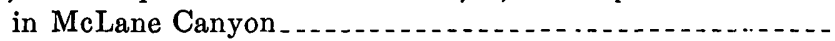

15. Sections of principal coals exposed in T. $11 \mathrm{~S} .$, R. $98 \mathrm{~W}$., and T. 1 N., R. 1 E. . . . . .

16. Sections of principal coals exposed in Tps. 10 and 11 S., R. 99 W., and T. 10 S., R. 100 W.

17. Sections of principal coals exposed in T. 9 S., R. $100 \mathrm{~W}$

18. Sections of principal coals exposed in Tps. 8 and 9 S., R. 101 W., and T. 8 S., R. 102 W

19. Sections of principal coals exposed in T. 8 S., R. $103 \mathrm{~W}$., and T. 7 S., R. 102 W 
Plate 20. Sections of principal coals exposed in Tps. 6 and 7 S., R. $103 \mathrm{~W}$ -

21. Sections of principal coals exposed in Tps. 6 and 7 S., R. 104 W.

Figure 1. Principal geographic features of Book Cliffs region........

2. Index map showing location of Book Cliffs coal field in Colorado

3. Lithologic composition of Mount Garfield and Hunter Canyon

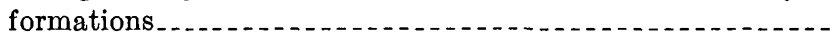

4. Sketch map of southern rim of Uinta Basin

5. Diagrammatic restoration of probable structural relationship between Uncompahgre Plateau and Book Cliffs

6. Heating value of Book Cliffs coals "as received" and of coals from adjacent regions with which they may come into com-

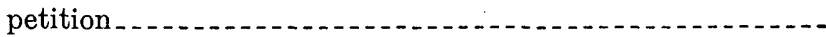

7. Seasonal fluctuations in production, Book Cliff mine, 18991901 


\title{
THE BOOK CLIFFS COAL FIELD IN GARFIELD AND MESA COUNTIES, COLORADO
}

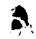

\author{
By Charles E. Erdmann
}

\begin{abstract}
The Colorado portion of the Book Cliffs coal field, which has an area of about 500 square miles, lies in Garfield and Mesa Counties, in central western Colorado. This field takes its name from the conspicuous escarpment flanking the north side of Grand Valley. Naturally the coal is most actively exploited in the more accessible area along the face of the cliffs and in the more open canyons. There are four producing areas-the Carbonera district, near the west boundary of the State, and the Grand Junction, Palisade, and Cameo districts. The coals are of bituminous rank and occur in four zones, three in the Mount Garfield formation of the Mesaverde group and one in the Mancos shale, all of Upper Cretaceous age. The total deposits of each zone, in short tons, are estimated to be, in the Anchor coal zone, 78,400,000; Palisade coal zone, $1,148,500,000$; Cameo coal zone, 3,529,000,000; Carbonera coal zone, $344,170,000$; local beds, $2,840,000$; total, about $5,103,000,000$.

The coal field is on the southern rim of the Uinta Basin, and in consequence the Mesaverde group, as well as the underlying Mancos shale and the overlying Wasatch and Green River formations (Eocene Tertiary), have a northward dip, which is usually low. There are, however, two prominent and some minor structural features that affect the regional inclination of the strata. One of these is a fairly steep monoclinal fold that increases the northward dip of the strata in a portion of the field, and the other is the Garmesa anticline. Deep wells that have been drilled on the anticline have discovered gas in the Dakota (?), Morrison, and Wingate formations.
\end{abstract}

\section{INTRODUCTION}

\section{LOCATION AND EXTENT}

The area described in this report has an extent of about 600 square miles in central western Colorado. The north half lies in the southwest corner of Garfield County, and the rest in the northwestern part of Mesa County. The natural geographic boundaries are the Roan Cliffs on the north and the Colorado River on the south and east. (See fig. 1.) The Colorado-Utah line marks the western limit.

The Book Cliffs coal field takes its name from the conspicuous Book Cliffs escarpment, which flanks the north side of Grand Valley. 
It is a part of the vastly greater Uinta Basin coal region, which, in Colorado, includes also the Grand Mesa, Crested Butte, Floresta, Mount Carbon, and Grand Hogback fields. The portion of the Book Cliffs coal field in Colorado, described in this report, is the narrow, irregular strip of country extending in a northwesterly direction from the towns of Cameo and Palisade to the State line, in Tps. 6, 7 , and 8 S., R. $105 \mathrm{~W}$. The southern limit of the field is the face of the Book Cliffs, and the northern limit is the base of the Green

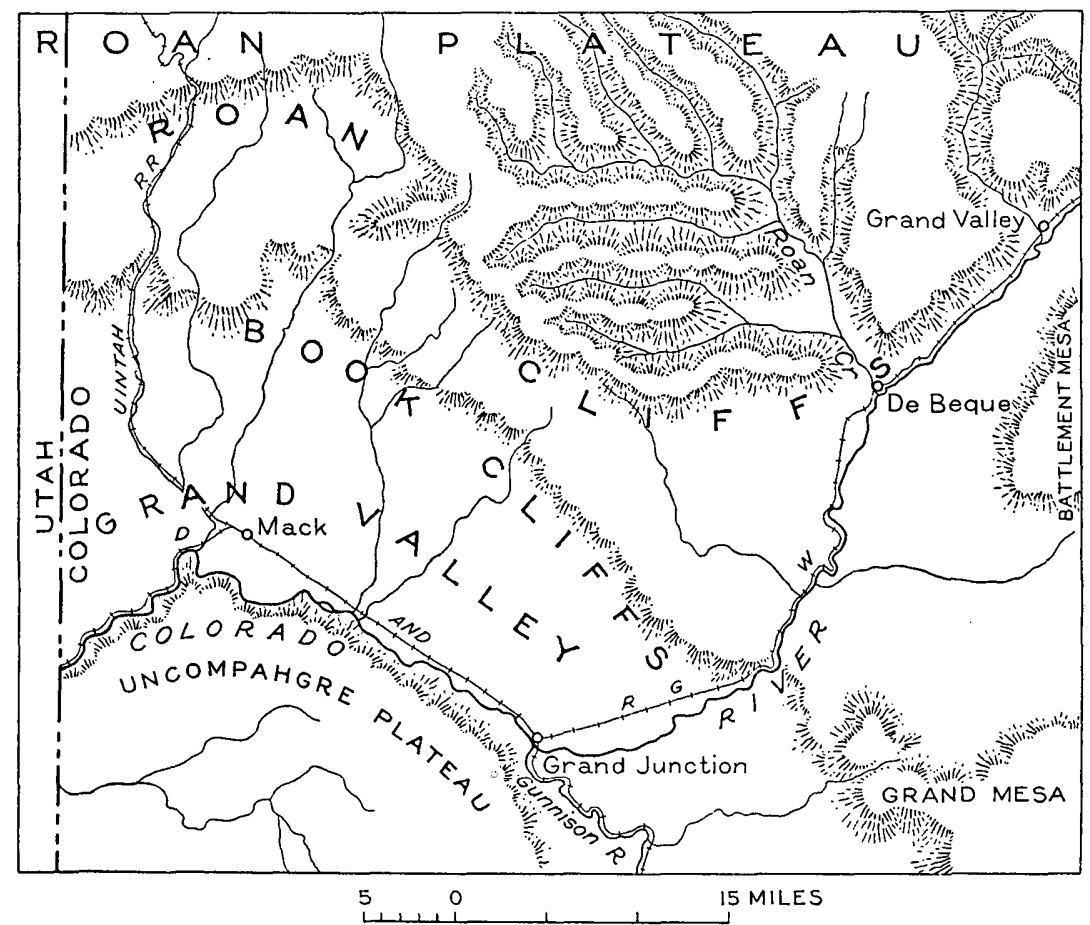

Figure 1.-Principal geographic features of Book Cliffs region.

River formation along the Roan Cliffs. This boundary in general marks the down-dip limits of the classifiable coals. The coal field thus has an area of about 500 square miles. Naturally the coal is most actively exploited in the more accessible area along the face of the cliffs and in the more open canyons. Four producing districts may be recognized-the Carbonera district, near the west boundary of the State; the Grand Junction district, which includes the mines along the cliffs from Salt Wash eastward to the old Book Cliff mine; and the Palisade and Cameo districts, at the east end of the Book Cliffs area.

The detailed mapping by the writer covers the area from Palisade westward. The area east of Palisade was studied by W. W. Boyer in 1924, and part of his work is incorporated in this report. 
The geographic and economic relations of this field to the larger competing fields in Colorado and Utah are shown on figure 2.

\section{ACCESSIBILITY}

The Denver \& Rio Grande Western Railroad, the only transcontinental route between the Union Pacific Railroad on the north and the Atchison, Topeka \& Santa Fe Railway on the south, serves the Book Cliffs coal field. The main line closely follows the north bank of the Colorado River. This route lies 10 to 18 miles from the most accessible outcrops of valuable coal along the face of the

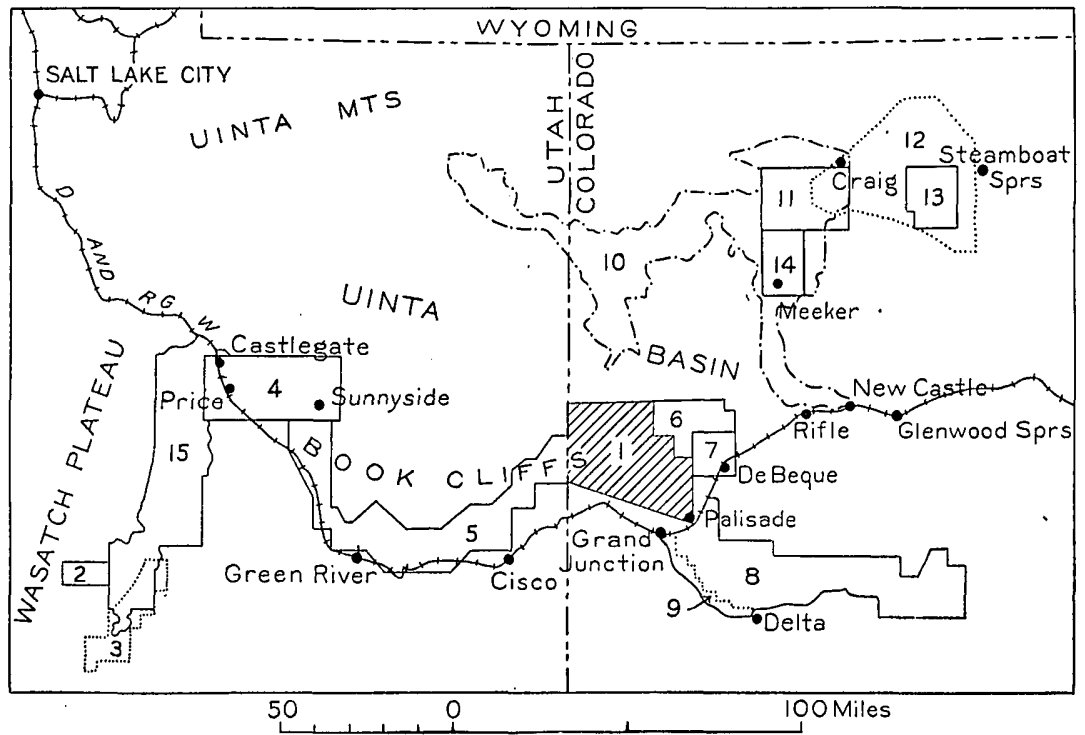

Frgure 2.-Index map showing location of Book Cliffs coal field in Colorado. 1, Thls report; 2, Salina Canyon, Bull. 796-C; 3, Castle Valley, Bull. 628; 4, CastlegateWellington, Bull. 793; 5, Book Cliffs, Utah, Bull. 852; 6, Book Cliffs, Colorado, Bull. $371 ; 7$, DeBeque, Bull. 531-C; 8, Grand Mesa, Bull. 510; 9, Gunnison Valley, Bull. 471-H ; 10, Northwest Colorado, Bull. 415 ; 11, Axial and Monument Butte quadrangles, Bull. 757 ; 12, Yampa, Bull. 297; 13, Twentymile Park, Bull. 748 ; 14, Meeker, Bull. 812 ; 15, Wasatch Plateau, Bull. 819.

cliffs in the central and western part of the field, and the only convenient shipping points are Palisade and Cameo, in the eastern part of the field.

The Uintah Railway, a narrow-gage line, runs north from the town of Mack, on the Denver \& Rio Grande Western Railroad, crosses the western part of the field, then follows the valley and canyon of West Salt Creek to the foot of the Roan Cliffs at Atchee. From Atchee it ascends the Roan Cliffs on a 7 percent grade and passes over them at Baxter Pass, where the descent into the Uinta Basin begins. This railway was built about 1904 for the purpose of more easily transporting gilsonite from the mines in the vicinity 
of Watson and Dragon, Utah, to the standard-gage railroad at Mack. In addition, there is considerable local traffic in the handling of passengers, mining supplies, coal from the Carbonera district, water, and stock.

The Midland Trail and the Pikes Peak Ocean to Ocean Highway, both national highways, follow the Denver \& Rio Grande Western Railroad across the east end of the area and then along its south side. Over the greater part of this distance the routes of the two highways coincide. They are graded throughout and graveled; short stretches near the city of Grand Junction are hard surfaced. Colorado State Highway 139, commonly called the Rangely Road: runs north from the town of Loma to the mouth of East Salt Creek Canyon in the Book Cliffs, thence up the canyon to the foot of the Roan Cliffs and over them at Douglas Creek Pass. This highway is the only road outlet to the south from the Uinta Basin between Price, Utah, and Meeker, Colo., a distance of 250 miles.

Though many dirt roads in the area lead up to coal mines along the cliffs, only two in addition to the Rangely Road extend as far as the Roan Cliffs. The better known is that which parallels the Uintah Railway from Mack to Atchee; the other runs up Salt Wash beyond the upper reservoir. These roads afford passage over the cliffs only for wagons or pack trains. A horse trail forks off from the road to the Anchor no. 1 mine, on the face of the Book Cliffs 5 miles east of Salt Wash, leads up the canyon that opens in sec. 35, T. 8 S., R. 101 W., and connects with the trail to the DeBeque Road in the McKay Fork of Dry Creek. The plateau in the eastern part of the area may be reached best by the DeBeque Road or by the Corcoran Wash Road.

Because of the rugged badland topography along the front of the Book Cliffs, there are no cross roads between the various coal mines. Narrow, tortuous horse trails exist, but to go from place to place by road long detours must be made. One of the most used roads in the region is that on the spoil bank of the United States Bureau of Reclamation High Line Canal. The narrow road roughly parallels the cliff front at a distance of 4 to 6 miles, except in the vicinity of Palisade, where it is at the foot of the cliffs.

With few exceptions, all roads in the region are built upon the Mancos shale, which has a broad expanse in Grand Valley. Where not graveled or paved they are very soft and sticky in wet weather and may be impassable for automobiles for a day or so after a heavy rain.

CONDITION OF LAND SURVEYS

Prior to 1881 this region was in possession of the Ute Indians. On September 4 of that year settlers were permitted to enter Grand 
Valley for the first time. Land surveys soon followed, the boundaries of most of the townships being established by control surveys from 1882 to 1885 . Most of the townships were subdivided in 1900; additional boundary surveys were made at the same time, and the corners were marked by set stones. As most of the stones have now disappeared, resurveys have been necessary in many places some of which were still in progress in 1927. All corners relocated since 1909 are marked by iron posts.

One of the most important resurveys and one upon which much dependence was placed during the geologic survey is that projected from the Ute base line and meridian in 1915. The iron posts of this survey extend on the north side of Grand Valley from the vicinity of Palisade to Mack and can be found without difficulty.

\section{PREVIOUS GEOLOGIC INVESTIGATIONS}

Probably the first white man to have more than a superficial knowledge of the Book Cliffs region was Antoine Roubidoux, a trader, who in 1840 established a small post just west of the present town of Delta, on the stream now known as the Gunnison River. $\mathrm{He}$ was soon dispossessed by the Ute Indians. Thirteen years later, in 1853, Capt. J. W. Gunnison, in search of a railroad route from the Mississippi Valley to the Pacific Ocean, led his party down the north side of the stream afterward named for him into Grand Valley. They crossed the Colorado River (then called the Grand) about $21 / 2$ miles above the mouth of the Gunnison and traveled westward, 1 to 4 miles north of the river. The "Roan or Book Mountains "are shown upon the resulting map ${ }^{1}$ by hachures in essentially their proper position, but the separate escarpments were not distinguished. Captain Gunnison reported coal from Salt Creek Canyon (probably the present West Salt Creek), describing the deposit as being " 100 feet long by 20 feet broad and about 1 foot thick. It is exposed to the weather but appears to be a good bituminous specimen." 2 The coal bed referred to is evidently one of the lignite beds in the Dakota (?) formation.

The pioneer geologist to visit the Book Cliffs was Peale, ${ }^{3}$ of the Hayden Survey. In 1875 he visited the Uncompahgre Plateau region, south of the Colorado River, and in September and October 1876 he carried his work to the north. His report gives a brief but fairly comprehensive description of the physical features and

${ }^{1}$ Beckwith, E. G., U. S. Pacific R.R. Expl., vol. 11 : 33d Cong., 2d sess., S. Ex. Doc. 78, pt. 11, map 4 [dated 1855, to accompany 2d paper in pt. 2], 1859.

2 Beckwith, E. G., U.S. Pacific R.R. Expl., vol. 2 : 33d Cong., 1st sess., H. Ex. Doc. 129, pt. 2 (2d paper), p. $61,1854$.

${ }^{3}$ Peale, A. C., Geological report on the Grand River district,. area B, Grand River Valley, Roan or Book Cliffs, Little Book Cliffs: U.S. Geol. and Geog. Survey Terr. 10th Ann. Rept., pp. 170-185, pls. 10-12, 1878. 
stratigraphy of the region. He does not mention the valuable coal beds along the Book Cliffs, though he noted the so-called "Dakota lignites" on the bluffs at the mouth of the Gunnison. ${ }^{4}$ Peale's colored geological map of the region is shown in the "Atlas of Colorado " of the Hayden Survey. ${ }^{5}$.

During the next 25 years the field was mentioned only in general descriptive articles. One of the first of these, more historical in scope than the others, is that by Thiele, ${ }^{6}$ in 1882 . Thiele noted that the early settlers burned oil-shale cobbles from the bed of the Colorado River, but that they later sent to the Crested Butte or Elk Mountain district for their coal rather than use the local supply. At the same time, however, promoters of the new town of Grand Junction or West Denver, as it was called for a while, "in their various and florid advertisements lay particular stress upon the coal." Thiele corroborates Hayden's opinion that, though traces of coal are found in the sandstones at the summit of the hogbacks along the Grand River, it is poor in quality and of no economic importance. The coal thus noted was probably the so-called "Dakota lignite."

In 1888 Hewett, ${ }^{7}$ in a discussion of the northwestern Colorado region, mentioned the Book Cliffs field specifically and reported favorably on the coals. Both Hills, ${ }^{8}$ in 1892, and Storrs, ${ }^{9}$ in 1901, in their papers on coal in Colorado, mentioned the deposits. A short time later Lakes, ${ }^{10}$ in 1904, described the Book Cliff coal mine in an interesting article, and in 1905 he mentioned the western Colorado coals in a more general paper. ${ }^{11}$

At this time a part of the Utah extension of the field was being examined in detail by J. A. Taff. Richardson ${ }^{12}$ made a reconnaissance study of the field in Colorado and Utah in 1906, which is worthy of note in that his report is the first devoted almost exclusively to coal in the Book Cliffs; considering the means available and the great area covered within the season, it is excellent. In 1906 and

\footnotetext{
4 Peale, A. C., Geological report on the Grand River district: U.S. Geol. and Geog. Survey Terr. 9th Ann. Rept., for 1875, pp. 91, 99, 1876.

5 Hayden, F. V., Geological and geographical atlas of Colorado and parts of adjacent territory, U.S. Geol. and Geog. Survey Terr., 1877.

- Thiele, L. W., The Grand River, Colo., coal measures: Eng. and Min. Jour., vol. 34, p. $345,1882$.

${ }^{7}$ Hewett, G. C., The northwestern Colorado coal region: Am. Inst. Min. Eng. Trans., vol. 17 , pp. $375-380,1889$.

${ }^{8}$ Hills, R. C., Coal flelds of Colorado: U.S. Geol. Survey Mineral Resources 1892, p. $353,1893$.

- Storrs, L. S., The Rocky Mountain coal fields: U.S. Geol. Survey 22d Ann. Rept., pt. 3, p. $436,1901$.

${ }^{10}$ Lakes, Arthur, The Book Cliffs coal mine: Mines and Minerals, vol. 24, pp. 289-291, January 1904.

11 Lakes, Arthur, The Grand River coal fleld: Mining Reporter, vol. 51, pp. 379-381, 1905.

Richardson, G. B., Reconnaissance of the Book Cliffs coal field: U.S. Geol. Survey Bull. 371, 1909.
} 
1907 Gale ${ }^{13}$ was working in the more northerly fields of the Uinta coal region; the southern limit of the area described by him, in the vicinity of Douglas Creek Pass, is within 10 miles of the northern limit of the area described in this report. From 1907 to 1909 the region adjoining the Book Cliffs field on the east was mapped by Lee. ${ }^{14}$ About the same time Woodruff ${ }^{15}$ examined the Dakota(?) i. coals cropping out along the lower Gunnison River. Campbell ${ }^{16}$ has given an interesting summary of the physical features, resources, and culture of the southern part of the field. In 1923 Winchester's report on oil shale ${ }^{17}$ appeared. The northern part of the area included in the present report overlaps the southern part of the area covered by his work, and some of his mapping is modified by the more recent field work.

The coals in the eastern part of the Book Cliffs field and the Grand Mesa field were studied by W. W. Boyer in 1924, and part of his work is incorporated in the present report. The Book Cliffs coal field in Utah, from the Sunnyside quadrangle eastward to the Colorado line, was mapped in detail in 1925 and 1926 by Fisher. ${ }^{18}$

\section{PRESENT INVESTIGATION}

The Book Cliffs coal field in Colorado was examined by the writer for the purpose of classifying the public lands. Field work was begun in the middle of June 1926 and continued to early October of that year. In September and October 1927 the area was again visited for 3 weeks, and additional information concerning the coals and stratigraphy was obtained. This objective made it necessary to map the outcropping coal beds with considerable detail on a scale of 2 inches to the mile, to determine the stratigraphic interval between the highest classifiable coal and the Wasatch-Green River boundary, and also to map this boundary. The nature of the field work therefore was varied to meet the different degrees of accuracy required. Although the strata are well exposed over the whole region, in most localities topographic conditions are unfavorable to detailed work without an undue expenditure of time and effort.

\footnotetext{
${ }^{13}$ Gale, H. S., Coal flelds of northwestern Colorado and northeastern Utah: U.S. Geol Survey Bull. 415, 1910.

14 Lee, W. T., Coal flelds of Grand Mesa and the West Elk Mountains, Colo.: U.S. Geol. Survey Bull. 510, 1912.

${ }^{25}$ Woodruff, E. G., The coal resources of Gunnison Valley, Mesa and Delta Countfes. Colo. : U.S. Geol. Survey Bull. 471, pp. 565-573, 1912.

10 Campbell, M. R., Guidebook of the western United States, Part E, The Denver \& Rio Grande Western Route: U.S. Geol. Survey Bull. 707, pp. 152-158, 184-195. sheet 7, 1922 .

${ }^{17}$ Winchester, D. E., Oil shale of the Rocky Mountain region: U.S. Geol. Survey Bull $729,1923$.

${ }^{18}$ Fisher, D. J., Preliminary map of the Book Cliffs coal field, Utaih (6 heets), U.S. Geol. Survey, 1928; The Book Cliffs coal field In Emery and Grand Counties, Uitab: U.S. Geol. Survey Bull. 852, 1934.
} 
No good topographic map of the area is available. That in the atlas of the Hayden Survey is inadequate. An effort, probably from this same source, has been made to indicate relief upon the Mack, Grand Junction, and Palisade sheets of the "Progressive military maps", but the result is not satisfactory. Excellent detailed topographic maps of the irrigable lands along the cliffs have been prepared by the engineers of the United States Bureau of Reclamation, but unfortunately they do not extend far enough north to be of service in coal mapping.

Under these conditions field work was naturally resolved into three principal classes of surveys-land, topographic, and geologiceach more or less distinct from the others, yet all interdependent. Each class of work was carried on separately, but some overlapping was unavoidable. A system of primary control was established and maintained, by which the coal outcrops in townships where no land corners could be found were accurately tied to the land net of the more recent surveys. Altitudes were carried from United States Geological Survey bench marks on this system in the eastern and central parts of the field and from the Uintah Railway in the western part. The scale of this work was 1 inch to the mile.

Because of the diverse topographic conditions several methods of mapping the coal were found necessary. The outcrops along the foot of the cliffs were mapped with a plane table by triangulation. In the deeper reentrants and canyons that break the regularity of the cliff front the coal beds and geologic boundaries were mapped by plane-table traverse run from a point from which the control points were visible. Pace and compass traverses were used to expedite the work in the more inaccessible tributary canyons and in areas where the poor quality or absence of coal justified these less accurate methods. The top of the Sego sandstone was chosen as the datum upon which the geologic structure of the field was worked out. This sandstone is the most persistent, most easily recognizable, and most accessible key bed in the field. In addition to the coal beds and geologic boundaries, field sketching included faults, axes of folds, and other structural data, drainage, culture, and geomorphic features.

Where possible, measurements and descriptions of the coal beds were taken at close and fairly regular intervals along the outcrops, but in most localities the inaccessibility, local burning, or slumping made measurement difficult and uncertain. It was thus most expedient to examine the beds thoroughly near their exposures on the canyon floors and in operating mines and other openings. Samples of fresh coal for chemical analysis were taken by standard methods from the working faces in all the operating mines or prospects. 
Detailed sections of the coal-bearing strata were taken at intervals of about 5 miles along the face of the cliffs. At intervals of about 9 miles detailed stratigraphic sections were taken from the top of the Mancos shale to the base of the Green River formation. In all of this work measurements were usually made by hand leveling, but at some places the major stratigraphic units were measured by stadia methods, the details between being filled in by hand leveling.

The boundary between the Wasatch and Green River formations is very distinct along the Roan Cliffs. It is marked by a pronounced change in color and in some places by a bench formed by a massive sandstone at the top of the Wasatch formation. It thus readily lends itself to mapping by intersection and sketching from triangulation stations along the crest of the Book Cliffs and from secondary points on the plateau. The boundary at the top of the Hunter Canyon formation was drawn at the same time by similar methods. It is less distinct and in some places can be recognized only with difficulty. For this reason the sketching is somewhat more generalized. Both of these boundaries were mapped on the primary-control sheets on a scale of 1 inch to the mile and are thus tied to the land net along the front of the cliffs.

\section{ACKNOWLEDGMENTS}

The writer takes this opportunity to express his many obligations to those with whom he was associated in the field. The work was carried on under the general supervision of C. E. Dobbin, of the United States Geological Survey. J. B. Reeside, Jr., furnished much valuable information concerning the stratigraphy of the region, C. H. Dane furnished information on the geologic section of the Uncompahgre Plateau, and G. H. Westby contributed data concerning the stratigraphy in the western part of the field. E. W. Scudder, F. P. Rushmore, and H. F. Davies supplied general information on the Garmesa dome. G. G. Law, of the Geological Survey, also contributed information on Garmesa dome and has read the portion of the manuscript pertaining to oil and gas. W. D. Johnston, Jr., and W. S. Glock served as the writer's assistants and mapped most of the coal. E. H. Watson assisted the writer for a short time in the fall of 1927. The coal-mine operators of the field afforded every facility for the advancement of the work, and much is due to their interest. Special acknowledgment is made of the numerous favors rendered by Mr. J. B. Bennett, of Carbonera. The writer is also under obligations to Mr. and Mrs. Charles W. Wilson, of the Garmesa ranch, for their many courtesies. 


\section{GEOGRAPHY}

\section{GEOMORPHOLOGY}

The Book Cliffs coal field forms a wide segment of the southern rim of the Uinta Basin as defined in the broadest structural and geomorphic sense. The sedimentary rocks of the region consist of an immense thickness of alternating hard and soft layers of sandstone and shale, which structurally may be pictured as a nested series of gigantic plates and saucers, the smallest at the top. In some places there is more or less irregularity or crumpling along the edges of the stack. The harder strata have marked topographic prominence as rims or cliffs, and the softer formations have been carved by discriminative erosion into asymmetric valleys, which have long dip slopes that terminate abruptly basinward at the succeeding cliffs. The topographic form developed upon each resistant formation or stratum is a cuesta, which consists of two elements-the high, steep erosional escarpment that forms the cliff face and the dip slope that forms the inclined structural plain. The term "cuesta" is sometimes applied to the inclined plain. Low-lying plains are commonly referred to as valleys, but high plains, especially those above a very high cliff, are usually called plateaus.

This general topographic form is remarkably well developed in eastern Utah from the Colorado River northward into the Uinta Basin. From south to north across the region there are three major series of cliffs. The lowest and most southerly series (the "Orange Cliffs" of Powell ${ }^{19}$ ) is in large part developed upon the Wingate sandstone and associated formations; the middle series (Book Cliffs) is developed upon the upper part of the Mancos shale and the rocks of the Mesaverde group; and the highest (Roan Cliffs) is developed upon the upper part of the Wasatch formation and basal part of the Green River formation. In the same order, above the cliffs, lie Grand Valley, which is eroded into the lower and middle portions of the Mancos shale; the plateau above the Book Cliffs, which is supported by the rocks of the Hunter Canyon and Wasatch formations; and the Roan Plateau, which rests upon the Green River formation. All these great features are included within the region herein described, each occupying roughly one-fourth of the area. In Colorado, however, because of the sharp flexure or fault bordering the Uncompahgre Plateau on the north, typical expression of the lower cliffs of the Wingate sandstone and associated formations is prevented.

Enclosing Grand Valley on the southeast and south are Grand Mesa and the Uncompahgre Plateau. Grand Mesa is the dominating

${ }^{10}$ Powell, J. W., Exploration of the Colorado River of the Kest, pp. 167-168, 1875. 


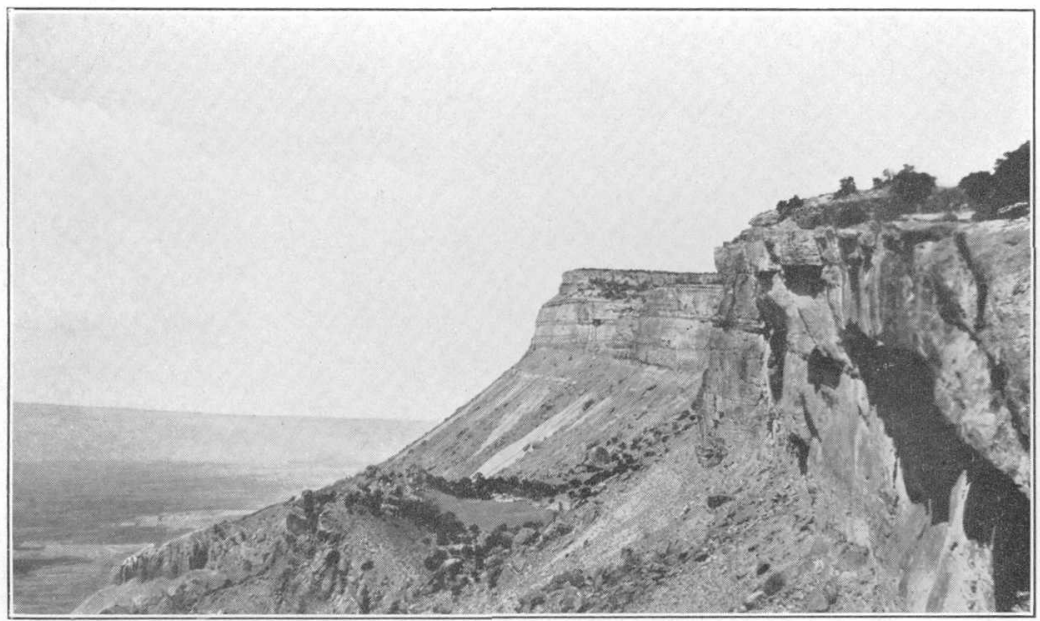

$A$, PROFILE OF BOOK CLIFFS ON SOUTH FACE OF MOUNT GARFIELD.

The slope is developed on the Mancos shale; the vertical cliff is developed on the lower part of the Mount Garfield formation. In the foreground is a large landslide block.

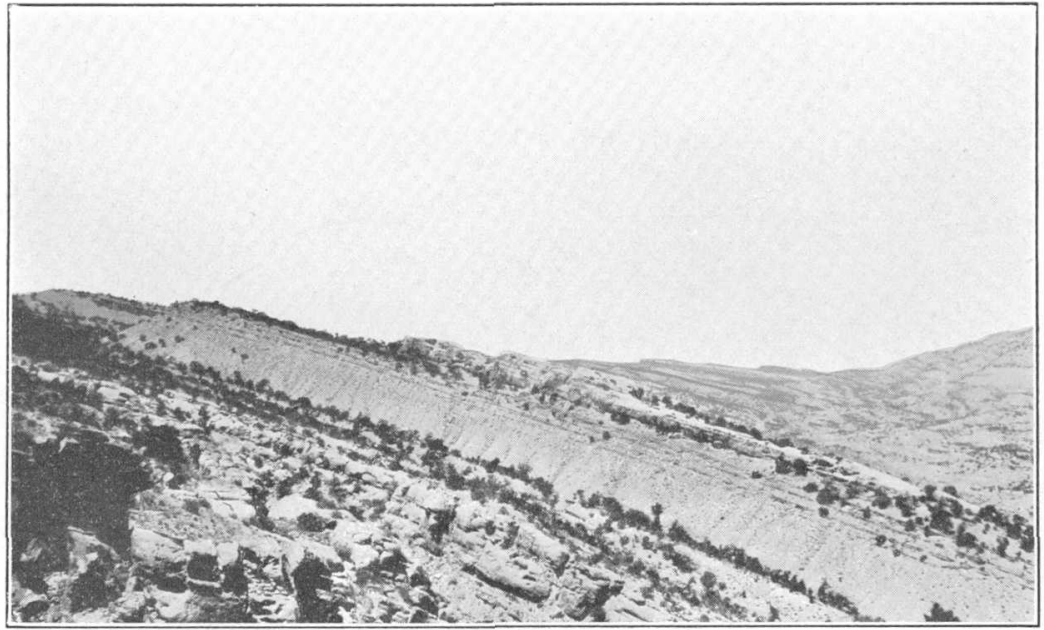

$B$, VIEW WESTWARD FROM NORTHWEST CORNER OF T. 11 S., R. 98 W.

The white Rollins sandstone forms an extensive dip-slope above the lower line of cliffs: the escarpment face of the higher cliffs appears in profile in the distance. The strata that crop out in the foreground consist of that portion of the Mount Garfield formation immediately below the Rollins sandstone. 


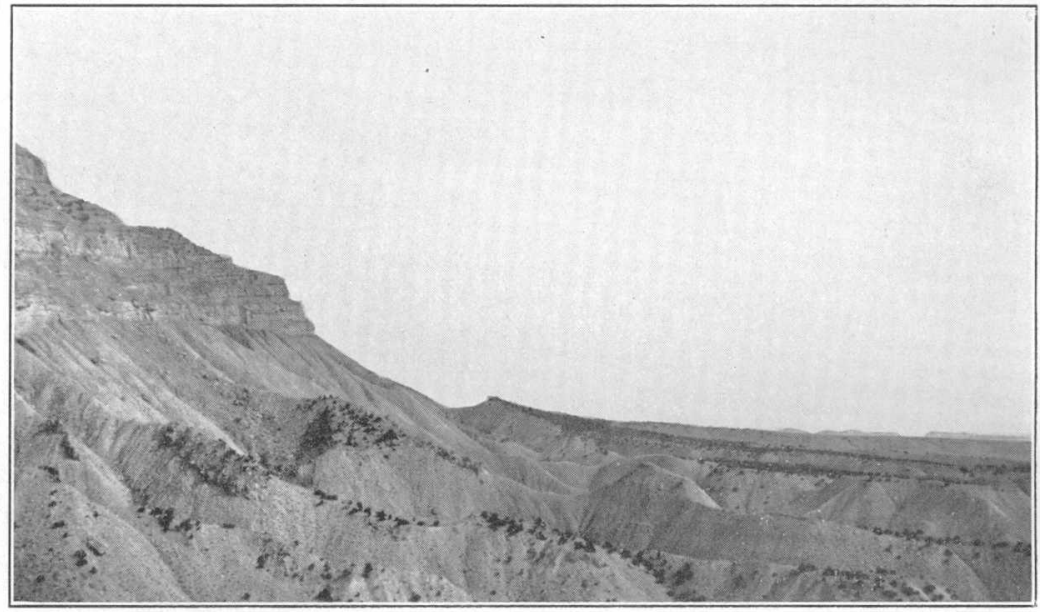

A, PROFILE OF BOOK CLIFFS EAST OF MOUTH OF HUNTER CANYON.

The dissected upper portion of the lower terrace is shown sweeping up to the base of the vertical cliff to which it once extended.

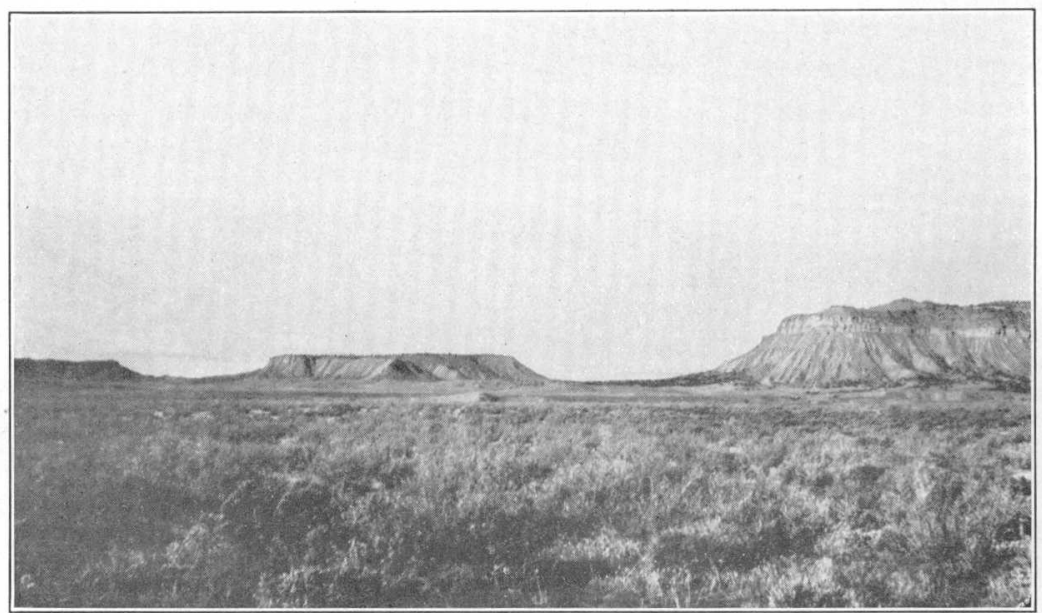

$B$, BEHEADED REMNANT OF THE HIGH TERRACE STANDING ON LOWER TERRACE PLAIN AT FOOT OF BOOK CLIFFS.

View westward from NE1/4 sec. 9, T. 8 S., R. 104 W. 
topographic feature of the entire region. Its flat summit, capped by basaltic lavas, is higher than the Roan Cliffs. The Uncompahgre Plateau, not so impressive as Grand Mesa or the Book Cliffs, effectively obscures the view to the south and is also a serious obstacle to. travel. From the western part of the coal field can be seen the long. extension of the Book Cliffs into Utah and, also, far to the southwest, the high serrate peaks of the La Sal Mountains.

\section{GRAND VALLEY}

Grand Valley is a great structural and erosional valley carved out. of the Mancos shale and flanked on the south by the Uncompahgre. uplift and on the north by the Book Cliffs. Its name was derived from the Grand River (now the Colorado River). The valley persists westward into Utah toward the mouth of the Dolores River and toward Cisco, but farther west its identity is lost; its total length is. thus 70 to 75 miles. The Colorado River flows through Grand Valley from Palisade, Colo., to a point a few miles southeast of Mack, beyond which it flows south of this structural valley through deep. canyons in the older, harder rocks.

Grand Valley is narrowest at Palisade, where it is about 3 miles. wide. It is 10 miles wide at the mouth of the Gunnison River, 15. miles near West Salt Creek, and about 20 miles near Cisco. Viewed from the heights of the Book Cliffs the valley floor appears to be flat, though there is a difference in altitude of 900 to 1,000 feet between. the river level and the cliff base. The long, gentle slope to the river is diversified by a relief of about 150 feet near the cliffs, but the relief becomes less riverward. In Colorado the central part of the floor is. irrigated and constitutes one of the leading agricultural areas in the western part of the State.

Two rock-cut benches have been developed upon the north side of Grand Valley, but no similar benches have been recognized in the harder rocks on the south side. Their trend is parallel to the cliff face, to which they once extended, and the interval between the two. ranges from 50 to 90 feet, becoming greater toward the cliffs.

The older and higher bench has been largely destroyed by erosion; its remnants, indicated on the map (pl. 1) by the roman numeral I, stand upon the lower, younger bench, which is indicated by the roman. numeral II. Northeast of Palisade the higher bench has been almost entirely destroyed, and even the lower one has been so thoroughly dissected that a typical badland topography has developed. Fartherwest along the cliffs the narrow, elongate remnants of the high bench are more numerous and extensive. They stand as small, isolated flat-topped buttes upon the headward portions of the lower bench. Few are within half a mile of the cliffs, but in the northwest corner- 
of sec. 30 , T. 9 S., R. 100 W., a remnant stands at an aititude of 5,465 feet, only 1,500 feet south of the cliffs. Evidently the cliffs have receded but little since the development of this bench. A reconstructed composite gradient of the surface of the higher bench, as determined from remnants lying within 4 miles of the cliffs in the central and western parts of the valley, is about 120 feet to the mile.

Within the area described in the present report the lower bench has not been greatly dissected along its northern margin, and it is usually separated from the rain-washed cliff face by a narrow gap. (See pl. 3, A.) It is cut by many broad, flat-floored trenches, whose depth may be as much as 70 feet near the cliff front but decreases to 45 or 35 feet a few miles south of the front. Present intermittent streams have incised narrow, vertical-walled gullies into these floors to a depth of 10 to 15 feet.

Adjacent to the Book Cliffs the gradient of the lower bench is $212^{\circ}$ to $3^{\circ}$, but it becomes less riverward, and the lower slopes have an inclination of about 45 feet to the mile. The difference in altitude between the lower margin of the bench and the Colorado River has not yet been determined. In general, from east to west the slope flattens as the distance from the river becomes greater. The profile immediately below Farmer's mine, in T. 8 S., R. 101 W., is essentially a parabolic curve. Locally reverse slopes have developed where the softer shales have been stripped from the harder limy or sandstone ledges in the Mancos shale, producing minor dip slopes.

The lower bench rises into the reentrants of the Book Cliffs, and the larger streams that break the front have only partly succeeded in removing it from the mouths of their canyons. This indicates that its development was relatively recent, probably during late Pleistocene time, after the major sculpturing of the cliffs. The high bench is so nearly destroyed that its relation to the large canyons trenching the Book Cliffs cannot be determined.

The general processes by which rock-cut benches are formed is well known, and the term "pediment" has been applied to similar forms in other regions. ${ }^{20}$ However, one and possibly both of the benches along the Book Cliffs east of Hunter Canyon have been modified during some earlier stage by river action or in part owe their origin to it. The Gunnison and the Colorado have developed broad terraces in the valley southwest of Grand Mesa, and the Gunnison may have flowed across Grand Valley and have been deflected to the southwest by the cliffs north of Grand Junction. Near the heads of some of the reentrants in the Book Cliffs, such as those at the Book Cliff mine (altitude 5,900 feet) and the Anchor no. 1 mine

\footnotetext{
${ }^{20}$ Paige, Sidney, Rock-cut surfaces in the desert ranges: Jour. Geology, vol. 20, pp. 443-450, 1920. Bryan, Kirk, Erosion and sedimentation in the Papago country, Ariz. : U.S. Geol. Survey Bull. 730, pp. 52-65, 1923.
} 
(altitude 5,450 feet), there are small residual patches of river gravel that consist of rounded cobbles of schist, gneiss, granite, and other igneous rocks, some quartzite, and more rarely limestone. These materials could not have come from a conglomerate in the overlying strata, as no such bed exists within the area. Such gravel is very rare upon the preserved surfaces of the benches. Near the cliffs the benches are mantled by a layer of rock debris, mostly fragments of sandstone (pl. 6, $A$ ), and near some of the larger stream pieces of algal limestone from the Green River formation are present. Most of the material is in an advanced state of disintegration, and the pieces become progressively smaller away from the cliffs. Locally the mass has been cemented into a surface breccia (fanglomerate). Over considerable areas the surface is covered with a thin coating of wind-blown silt and dust.

\section{BOOK CLIFFS}

Uses of the term "Book Cliffs."-The term "Book Cliffs" has been in loose though current usage for a great many years. It probably first appeared in print in 1854, in the narrative of Captain Gunnison's explorations. ${ }^{21}$ In 1861, as "Roan and Book Cliffs": it was applied in a general way to both the Mesaverde and Green River escarpments, as shown on the War Department map of these operations. $^{22}$ No doubt local usage antedates this, but no record of it is available. The name is said to have been derived from the regular way in which beds of alternating shale and sandstone are piled upon one another like books lying on a table. ${ }^{23}$ Gannett ${ }^{24}$ and Campbell ${ }^{25}$ state that the name was given because of the fancied resemblance of the sandstone cap and curved shale slope below to the edge of a bound book.

Powell ${ }^{26}$ in 1869 , when he passed through the cliffs on the Green River, restricted the use of "Book Cliffs" to the Mesaverde escarpment and "Brown" (Roan) to the Tertiary (Green River) cliffs. It is regrettable that this usage has not been followed more strictly.

In 1875 Peale $^{27}$ used the terms in a general way, and in 1876 he applied the term "Roan or Book Cliffs" to the Mesaverde escarpment in Utah and in Colorado west of East Salt Creek, "Little Book Cliffs" to the same escarpment from East Salt Creek to Palisade,

\footnotetext{
${ }^{21}$ Beckwith, E. G., op. cit., p. 57.

2 Idem, map 4.

${ }^{23}$ Lal:es, Arthur, Mines and Minerals, vol. 24, pp. 289-291, January 1904.

${ }^{24}$ Gannett, Henry, Report of topographer of the Grand River division: U.S. Geol. and Geog. Survey Terr. 9th Ann. Rept., p. 346, 1877.

${ }^{25}$ Campbell, M. R., Guidebook of the western United States, Part E, The Denver \& Rio Grande Western Route: U.S. Geol. Survey Bull. 707, p. 186, 1922.

${ }^{30}$ Powell, J. W., Exploration of the Colorado River of the West and its tributaries, pp. 170-174, 1875 .

${ }^{27}$ Peale, A. C., Geological report on the Grand River district: U.S. Geol. and Geog. Survey Terr. 10th Ann. Rept., pp. 173-176, 1878.
} 
and "Roan or Book Plateau" to the Roan Plateau as defined in this report. This nomenclature is confusing, as there is overlapping in the application of the names to features which are entirely distinct. However, it is this usage which has been established by the Hayden Atlas of Colorado and has been followed by most writers; deviations from this usage have tended still farther away from any system. Thus the Roan or Parachute Cliffs in the vicinity of Rifle have recently been called the "Book Cliffs"; near DeBeque they are known locally as the "White Cliffs"; and Winchester ${ }^{28}$ has referred to the part in Tps. 6 and 7 S., R. 101 W., as the "Little Book Cliffs."

There is no adequate reason for naming a subdivision of the Book Cliffs. Throughout their extent they are a complete geologic and topographic unit. West of East Salt Creek they are no higher and in some respects not so impressive as they are to the east. Only in the sector east of the Book Cliff mine, where the cliffs form a double line, was there any justification for the use of the term "Little Book Cliffs." This name will now be discarded.

Surface features.-The Book Cliffs have already been referred to as the escarpment slope of a huge cuesta. The distance along this front from Palisade, Colo., where it unites with Grand Mesa, to Castlegate, Utah, where it terminates in the Wasatch Plateau, is: about 180 miles. The trace of the escarpment over this distance is a long, sinuous $\mathbf{S}$ curve, and it marks, with only minor modifications, an unbroken geologic and topographic unit. The major deflections making the $\mathbf{S}$ curve and also some of the minor ones are due to structural causes.

In Colorado the Book Cliffs form the north wall of Grand Valley. When viewed from a distance the mountainous front appears unbroken, but considered in detail it consists of a long succession of reentrants and spurs and ribs, with a few broader and deeper embayments where it is breached by large streams. (See pls. 2, 3.)

The imposing appearance of the lower part of the cliffs is due to the protective effect of a massive sandstone on the Mancos shale and the erosional sculpturing of the shale. Along the foot of the cliffs, between the heads of the benches already described and the steep Mancos slope, there is a narrow belt of badland topography. Its extreme ruggedness is broken here and there by a smooth, even extension of a shale abutment or by the northward projection of a terrace. The complex dissection.disappears as the slopes of the cliffs are followed upward and changes abruptly into the massive abutments of the converging fluted shale columns, which rise rapidly to the sheer sandstone cliff 200 to 350 feet high.

${ }^{28}$ Winchester, D. E., Oil shale in the Rocky Mountain region: U.S. Geol. Survey Bull. 729 , pl. 8,1923 . 
The cliff face immediately above the sandstone wall presents an aspect much different from that below. In general it is a rather steep slope, rarely more than $30^{\circ}$, broken by numerous projecting edges of the massive sandstone beds. Locally these are obscured by the loose debris from the more shaly beds. This portion of the cliff face contains the valuable coal beds, and where these are burned the prevailing gray-brown color becomes pinkish and the wash from the colored beds sometimes paints the strata below. This slope gradually steps upward to a massive brown sandstone, which usually forms the crest line of the cliffs. In Colorado this stands at altitudes ranging from 6,500 to 7,000 feet, but the maximum height is reached a mile or so back from the top of the Mancos shale and may be as much as 7,400 feet. The base of the cliffs has an average altitude of about 5,500 feet; thus the total relief of the Book Cliffs front ranges from 1,400 to 2,000 feet. The total relief from the crest to the bottom of Grand Valley is about 3,000 feet.

\section{PLATEAU BETWEEN THE BOOK AND ROAN CLIFFS}

The dip slope of the cuesta whose escarpment slope constitutes the Book Cliffs is a long, irregular strip of plateau that extends northwestward from Grand Mesa. The surface is supported by the massive sandstones of the Mesaverde group and by a considerable part of the Wasatch formation. The southern margin is, of course, the crest line of the Book Cliffs, and the northern boundary grades into the toe of the Roan Cliffs. The width of the plateau ranges from a maximum of about 15 miles in the eastern part of the field to 6 miles in the central part. There is a gradual widening again in the west, where, owing to the structure, the resistant supporting beds are upheld over a greater area and the normal width of the plateau is about doubled.

Viewed in profile the surface shows a remarkably even summit level. There is usually a short dip slope just north of the crest line of the Book Cliffs, and then beds higher and higher in the geologic column come in, and the surface tends to rise gradually toward the Roan Cliffs. The altitude of the inner margin is about 7,500 feet, and the outer margin, at the crest of the Book Cliffs, averages at least 7,000 feet. Long promontories of younger rocks extend out upon the plateau from the north. Locally these have been detached from the main bodies by erosion and now stand upon the surface as outliers. The most prominent outlier is Corcoran Peak, but there are several other conspicuous points near the Douglas Creek Pass. The plateau is so much dissected by the streams that head in the Roan Cliffs or on the Roan Plateau and by their numerous youthful tributaries that probably not more than 15 per- 
cent now remains of the entire surface that was uncovered by the recession of the base of the Roan Cliffs.

\section{ROAN CLIFFS}

The Roan Cliffs are the escarpment slope of the huge cuesta of the Green River formation, whose dip slope forms the Roan Plateau. The basal portion of the cliffs is developed upon the Wasatch formation, and the name is said to be derived from the characteristic variegated red, gray, brown, and bluish colors of the clay shales of this formation. $^{29}$ However, the greater portion of the escarpment is carved upon the resistant limestones, sandstones, and shales of the Green River formation.

Because the Roan Cliffs are situated so far back of the Book Cliffs they are in large part invisible from Grand Valley, hence their great height, ruggedness, and inaccessibility are not fully appreciated. The long, steep, barren escarpment extends far into Utah on the west and beyond DeBeque on the east, forming an effective barrier to entrance into the Uinta Basin from the south. The Roan Cliffs are fully as high from base to top as the Book Cliffs, and more precipitous; the altitude of the crest line ranges from 8,400 to nearly 9,000 feet. Rapid headward erosion of the many small streams that flow from them is facilitated by the more abundant rainfall at the higher altitude. This has produced the semicircular embayments or amphitheaterlike forms, the serrate spurs that project sharply out upon the minor stream divides, and the vertical white landslide scars or "slides", all of which characterize the cliff face in some localities.

ROAN PLATEAU

The Roan Plateau is developed wholly upon the Green River formation within the area mapped, but in the Uinta Basin the surface may rest upon the Uinta formation. Its drainage is largely basinward into the White River. Because of the gentler slope of the streams and uniformity of the supporting rocks, the surface is more uniform and better preserved than that of the plateau between the Roan and Book Cliffs. The crest line, as marked by the Roan Cliffs, is also very even. The gently rolling surface was formerly well forested, but the trees have been burned off over considerable areas, and the plateau now affords excellent summer grazing.

\section{DRAINAGE AND WATER SUPPLY}

The region is drained by the Colorado River, which rises near the Continental Divide, to the east. South of Grand Junction the Colorado is joined by the Gunnison River, and these are the only peren-

${ }^{29}$ Beckwith, E. G., op. cit., p. 61. Peale, A. C., U.S. Geol. and Geog. Survey Terr. 9 th Ann. Rept., p. 346, 1877. 
nial streams in the region. The drainage patterns are relatively simple. A modified rectangular or trellis pattern is shown by the Colorado and its tributaries from the north, but the individual tributaries have usually a normal dendritic pattern. The principal stream divide in the region is that between the White and Colorado Rivers. It closely follows the crest line of the Roan Cliffs. The central and western portions of the region herein described are drained by four large intermittent washes, which head in these cliffs and are considerably augmented by numerous tributaries that dissect the plateau above. The northeastern part of the field lies in the Roan Creek and Asbury Creek drainage areas. The actual face of the Book Cliffs is furrowed with innumerable small washes. Many of these unite with the larger ones, but others maintain their own short courses to the Colorado.

East and West Salt Creeks are the largest washes that pass through the cliff front, but Salt Wash and Hunter Wash are nearly as large. During the hot summer these creeks are commonly dry in their lower courses, except for local pools of alkaline water; upstream the pools become more abundant, and in their canyon portions slight flows may be found. Back of the cliff front the steep-walled trunk valleys, with the exception of Hunter Canyon, are long, open, but narrow, and without conspicuous projecting spurs. They contain alluvium and have flat graded floors into which the stream channels are , trenched 10 or 20 feet. Their tributary valleys are narrow, tortuous, rock-floored, and in general ungraded. Where some of the tributaries cross massive sandstone ledges they form small box canyons. East and West Salt Creek Canyons flare out abruptly at the cliff front; the opening of Salt Wash flares less, and Hunter Canyon preserves the canyon character up to the cliff face. Hunter Canyon also differs from the others in being deep, narrow, rock-floored, and ungraded, but near its head it widens out into the soft Wasatch clays more noticeably than the others. All these washes are subject to violent and destructive cloudbursts and should be avoided if there is prospect of a storm.

Good drinking water does not occur along the Book Cliffs. The accessible portion of the coal field is a desert, and most of the townships along the front have no water of any kind. The working mines are supplied with water for domestic purposes from Grand Junction, Fruita, or Atchee. No water is used in treatment of the coal. At the old Book Cliff mine there is a small spring of alkaline though usable water, which has a flow of about $11 / 2$ gallons a minute; this is the largest spring of usable water on the cliffs. Several hundred feet higher, at the base of the Cameo coal zone, there is another small spring. Small springs or seeps of alkaline water run from the outcrop of the Cameo coal zone in sec. 27, T. 8 S., R. $101 \mathrm{~W}$., and 
other springs issue near the creek in sec. 22. A series of springs and rock tanks occurs along the toe of Rollins sandstone dip slope in T. 1 N., R. 1 E., but this small area is very difficult of access, and the supply of water is small and would be inadequate in the summer.

The Uintah Railway is supplied with water from a group of springs near Atchee, from which the water is hauled in tank cars to reservoirs at Carbonera and Mack. The company generously supplies the traveler or worker in the region with small quantities of water, but if considerable amounts are required they can be purchased in tank-car lots at about a quarter of a cent a gallon, f.o.b. Atchee.

Flooding by ground water has caused the abandonment of the Anchor no. 1 mine. The water probably enters along the coal zone which crops out in the canyon floor nearby. Salt water was encountered in the Gypsy Oil Co.'s well in sec. 9, T. 9 S., R. 101 W., at depths of 265 feet and lower.

Small amounts of water are available in East and West Salt Creeks during the summer, but it is so strongly alkaline that it is dangerous to use for stock, and the quantity is hardly sufficient for irrigation. Many other washes contain shallow pools of water, and a small supply could probably be obtained in many places by digging shallow wells. Pools and springs become more numerous toward the Roan Cliffs, but the quality of the water does not improve until the White River drainage basin is reached.

The larger creeks have fair-sized streams in the spring, when the snows on the higher cliffs are melting, or after rainy periods. Dur. ing these times the water is fresh, and as much as possible is stored in reservoirs for use later in the season. The Ruby Lee Reservoir, in secs. 14 and 23, T. 8 S., R. 102 W., is the largest. However, the winter snows are as uncertain as the summer rains, and consequently in some years there is very little water. The recent burning of the forests along the Roan Cliffs and Roan Plateau has apparently accentuated this condition, and the problem of water from local creeks for irrigation and stock raising is yearly becoming more serious.

The life of both dams and reservoirs is short in the region. The reservoirs silt up rapidly and the dams are usually burst by floods, even before the artificial ponds are silted up.

The Grand Valley project of the United States Bureau of Reclamation, usually referred to as the High Line Canal, parallels the accessible part of the coal field at a distance of 4 to 5 miles from Clifton to West Salt Creek; east of Clifton it runs along the foot of the cliffs. About 35,000 acres lies below the main canal and is supplied by gravity, and about 20,000 acres of this is now included in cultivated farms. The water is diverted from the Colorado River 
about 8 miles above Palisade and flows in an open ditch for more than 60 miles. This project is the greatest potential source of water for the coal field and has been utilized by some of the oil companies that have drilled wells in search of petroleum along the cliffs. The water is potable, but near the end of the canal it may be slightly alkaline; at times it is muddy but soon clears upon standing.

\section{CLIMATE}

The climate in Grand Valley is arid, and the aridity affects the accessible portion of the coal field. Though small thunderstorms are frequent during the summer, the rainfall is slight; and over a period of 33 years the mean annual rainfall at Grand Junction has been only 8.3 inches. Strong local winds may blow along the flats below the cliffs, and an occasional dust storm may cover the whole valley. During the summer the daytime temperatures in the desert may be rather high, but the nights are always cool. In the daytime the winds blow up the valleys in the cliffs; shortly after sunset they reverse and blow down the valleys until a few hours after sunrise. No meteorologic data are available for the plateau areas above the Book and Roan Cliffs, but their altitude (about 7,000 and 8,500 feet, respectively) induces a climatic change that ranges from semiarid to nearly humid. The winters are long and severe on the plateaus, in marked contrast to the mild, open winters of the valley, which has the advantage of lower altitude and of the protection afforded by the surrounding highlands. The mild winters are an important factor in reducing the length of season in which coal must be burned, and thus they affect the local market. The table below presents a climatic summary for Grand Junction. ${ }^{30}$

Average and comparative meteorologic data for Grand Junction, Colo.

\begin{tabular}{|c|c|c|c|c|c|c|c|c|c|c|c|c|c|c|}
\hline \multirow[t]{3}{*}{. } & \multicolumn{7}{|c|}{ Temperature } & \multirow{2}{*}{\multicolumn{3}{|c|}{$\begin{array}{r}\text { Relative } \\
\text { humidity } \\
\text { (percent) }\end{array}$}} & \multicolumn{4}{|c|}{ Precipitation } \\
\hline & \multirow[b]{2}{*}{ 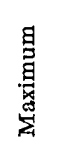 } & \multirow[b]{2}{*}{ 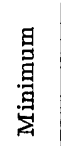 } & \multirow[b]{2}{*}{ 㖁 } & \multirow{2}{*}{ 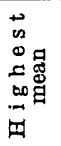 } & \multirow{2}{*}{ 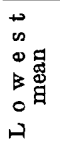 } & \multirow{2}{*}{ 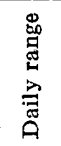 } & \multirow{2}{*}{ 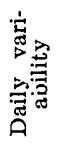 } & & & & \multirow[b]{2}{*}{ 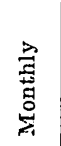 } & \multirow{2}{*}{ 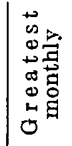 } & \multirow{2}{*}{ 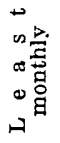 } & \multirow[b]{2}{*}{ 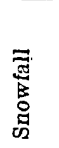 } \\
\hline & & & & & & & & $\underset{\dot{g}}{\dot{g}}$ & $\begin{array}{l}\square \\
: \\
z\end{array}$ & $\begin{array}{l}\dot{a} \\
\dot{0} \\
0\end{array}$ & & & & \\
\hline Years of record & 33 & 33 & 33 & 33 & 33 & 33 & 33 & 27 & 10 & 27 & 33 & 33 & 33 & 33 \\
\hline $\begin{array}{l}\text { January } \\
\text { February.- } \\
\text { March } \\
\text { April. } \\
\text { May. } \\
\text { June... } \\
\text { July.... } \\
\text { August } \\
\text { September.- } \\
\text { October } \\
\text { November.- } \\
\text { December.. }\end{array}$ & $\begin{array}{l}36.0 \\
43.7 \\
54.8 \\
64.9 \\
74.6 \\
86.2 \\
91.2 \\
88.3 \\
79.6 \\
65.8 \\
52.1 \\
38.0\end{array}$ & $\begin{array}{l}14.3 \\
22.6 \\
31.7 \\
39.4 \\
47.8 \\
57.0 \\
63.8 \\
62.0 \\
52.9 \\
40.1 \\
28.4 \\
17.2\end{array}$ & $\begin{array}{l}25.1 \\
33.0 \\
43.3 \\
52.2 \\
61.2 \\
71.6 \\
77.5 \\
75.2 \\
66.2 \\
53.0 \\
40.2 \\
27.6\end{array}$ & $\begin{array}{l}35.0 \\
43.4 \\
51.2 \\
56.8 \\
66.8 \\
77.0 \\
82.0 \\
77.6 \\
70.2 \\
58.1 \\
45.1 \\
36.4\end{array}$ & $\begin{array}{l}14.2 \\
15.3 \\
36.2 \\
45.6 \\
55.1 \\
66.8 \\
74.7 \\
72.2 \\
60.1 \\
48.4 \\
35.8 \\
15.6\end{array}$ & $\begin{array}{l}21.7 \\
21.1 \\
23.1 \\
25.4 \\
26.7 \\
29.2 \\
27.4 \\
26.6 \\
26.7 \\
25.6 \\
23.7 \\
20.8\end{array}$ & $\begin{array}{l}4.0 \\
3.4 \\
4.0 \\
4.4 \\
4.1 \\
3.4 \\
2.3 \\
2.5 \\
3.2 \\
3.1 \\
3.2 \\
3.2\end{array}$ & $\begin{array}{l}83 \\
77 \\
66 \\
61 \\
53 \\
44 \\
50 \\
55 \\
56 \\
63 \\
70 \\
80\end{array}$ & \begin{tabular}{l|}
66 \\
51 \\
38 \\
33 \\
25 \\
20 \\
29 \\
33 \\
33 \\
36 \\
78 \\
60
\end{tabular} & $\begin{array}{l}66 \\
54 \\
39 \\
31 \\
25 \\
20 \\
25 \\
29 \\
30 \\
38 \\
47 \\
62\end{array}$ & $\begin{array}{r}0.55 \\
.56 \\
.77 \\
.76 \\
.79 \\
.38 \\
.57 \\
1.13 \\
.84 \\
.97 \\
.59 \\
.54\end{array}$ & $\begin{array}{l}1.24 \\
1.77 \\
2.36 \\
1.78 \\
2.74 \\
1.74 \\
1.43 \\
3.65 \\
3.78 \\
3.43 \\
2.39 \\
1.54\end{array}$ & $\begin{array}{l}0.05 \\
\text { Tr. } \\
.02 \\
.13 \\
.03 \\
\text { Tr. } \\
\text { Tr. } \\
.02 \\
\text { Tr. } \\
\text { Tr. } \\
0 \\
\text { Tr. }\end{array}$ & $\begin{array}{l}5.4 \\
4.8 \\
2.7 \\
.8 \\
.1 \\
0 \\
0 \\
0 \\
\mathrm{Tr} . \\
.3 \\
2.1 \\
5.4\end{array}$ \\
\hline Annual. . & 64.6 & 39.7 & 52.2 & 54.5 & 49.9 & 24.8 & 3. 3 & 63 & 42 & 39 & 8.45 & 11.61 & 3.64 & 21.7 \\
\hline
\end{tabular}

so Annual meteorological summary with comparative data, Grand Junction, Colo., U.S. Weather Bureau, 1925. 


\section{VEGETATION}

Over the greater part of the region the scant vegetation is of the desert type. These forms are especially well established on the terraces along the foot of the cliffs. The heads of some of the terraces support a meager growth of stunted junipers and a considerable amount of sagebrush. Farther out the vegetation is more sparse, the sagebrush is smaller, greasewood appears, and stunted Russian thistle is abundant. All the slopes on the Mancos shale are characteristically barren. The alluvium in the longer washes supports a few cottonwood trees and a fairly rank growth of sagebrush. Prickly pear is the only variety of cactus found. Some varieties of yucca are present but are not plentiful. ${ }^{31}$

The contrast in vegetation between the desert valley, green only where irrigated, and the plateau above the Book Cliffs is striking. On the plateau juniper and piñon abound, together with a few longleaf pines. Thickets of scrub oak border some of the washes, and greasewood and black sage are everywhere plentiful. Bunch grass grows rather thickly, and some parts of the plateau are utilized for grazing. All the timber is second growth, and very few of the trees are suitable for mine timber. The pines and spruce so characteristic of the higher slopes of the Roan Cliffs and Roan Plateau begin to appear at an altitude of about 7,000 feet and locally are abundant. Quaking aspen first appears slightly higher. Landslides have destroyed a great part of the forests along the face of the Roan Cliffs, and large areas on the Roan Plateau have been destroyed by forest fires.

Much of this timber is suitable for mine props, but it is all more or less inaccessible and no sawmill is available for shaping it. The mines that require timbers import them from other regions.

\section{CULTURE}

Grand Junction, the county seat of Mesa County, is the largest town in the region. It had a population of 10,247 in 1930 and is the geographic and economic center of the western slope of Colorado and of eastern Utah. It is situated in Grand Valley at the junction of the Colorado and Gunnison Rivers, on the main line of the Denver \& Rio Grande Western Railroad, and is also on the Pikes Peak Ocean to Ocean Highway and the Midland and Rainbow Trails. The city is supported by fruit growing, gardening, dairying, and stock raising, by manufacturing and jobbing, and by the trade that comes to it as a railroad center. Its field of influence covers about 50,000 square miles. Palisade is on the railroad 10 miles east of

\footnotetext{
${ }^{31}$ Brooks, L. R., and others, Land classification in western Colorado, U.S. Geol. Survey, 1933.
} 
Grand Junction. It is especially noted for its fruit orchards, though some coal is shipped from there as well. In 1930 its population was 851. Fruita, which lies 10 miles northwest of Grand Junction on the railroad, is predominantly an agricultural town, with a population of 1,053 in 1930 . Loma (population 672 in 1930) is a small agricultural town 4 miles west of Fruita, at the point where the Rangely Road turns north across the desert. Mack (population 451), the most westerly town in the area, is the southern terminus of the Uintah Railway, which maintains a good hotel there. Cameo is a small coal-mining town on the main line north of Palisade, in the eastern part of the field. Carbonera is a small coal-mining town on the Uintah Railway, about 20 miles north of Mack, populated by the coal miners, their families, and the section crew. Atchee is a division point on the Uintah Railway at the foot of the Roan Cliffs and is exclusively a railroad town.

Practically the whole population of the region lives in Grand Valley within the irrigated area. Except for a few people at a coal mine or a ranch here and there the Book Cliffs region is unpopulated.

\section{STRATIGRAPHY}

\section{GENERAL FEATURES}

The geologic formations of the Book Cliffs coal field and the Grand Valley region range in age from the red beds of the Upper Triassic to the Quaternary. The total thickness of this great sequence of sedimentary rocks is roughly 10,000 feet, and the beds are remarkably well exposed across the gently upturned southern margin of the Uinta Basin. The coal beds occur just above the middle of this section, and as they were the principal object of investigation, they and their associated rocks were studied in much greater detail than either the younger or the older strata. The cover on the coals consists of the younger formations, and as the thickness of cover is a fundamental factor in determining the area of the classifiable coals it has been measured with considerable care. Measurements at several places within the field afforded the opportunity for study of these younger rocks. From an economic point of view the base of the coal-bearing rocks marks the outer boundary of any coal region or individual field, and it is but natural that little attention should be paid to the strata below the coals. However, it is known that some of these older formations are possible sources of oil and gas and that in some localities in the Book Cliffs field structural conditions are favorable for the accumulation of these substances. At such places the strata have been explored by deep wells, and much additional stratigraphic information concerning the concealed rocks has been obtained. 
About half of the total thickness of the strata is made up of beds laid down in shallow lakes and on broad river flood plains; this is especially true of the younger formations. Other beds were deposited in estuaries along the ancient seacoasts; at many places they show an alternation of marine and continental conditions; but the greater portion was laid down in the sea. No igneous rocks are exposed in this area, but such rocks are found not far distant in the Uncompahgre Plateau, in the laccoliths of the La Sal Mountains, and in the massive basaltic lava flows that cap Grand Mesa.

A summarized description of the exposed rocks of the Book Cliffs region of Colorado is given below in tabular form for convenient reference and direct comparison.

Summary of exposed rock formations in the Book Cliffs region, Colorado

\begin{tabular}{|c|c|c|c|c|c|}
\hline Age & \multicolumn{2}{|c|}{$\begin{array}{l}\text { Group, formation, } \\
\text { and member }\end{array}$} & Character & $\begin{array}{l}\text { Thick- } \\
\text { ness } \\
\text { (feet) }\end{array}$ & Economic value \\
\hline Quaternary. & \multirow{2}{*}{\multicolumn{2}{|c|}{ 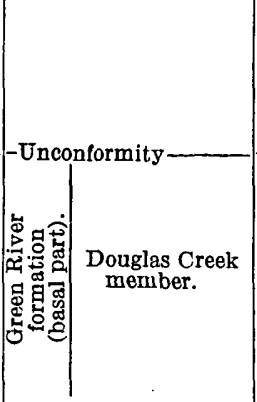 }} & $\begin{array}{l}\text { Alluvial material covering ter- } \\
\text { race remnants in front of cliffs; } \\
\text { sandstone, sand, and algal } \\
\text { limestone; locally stream grav- } \\
\text { el containing pebbles of igne- } \\
\text { ous and metamorphic rocks. }\end{array}$ & $0-30^{\prime}$ & None: \\
\hline \multirow[t]{2}{*}{$\begin{array}{l}\text { Tertiary } \\
\text { (Eocene). }\end{array}$} & & & $\begin{array}{l}\text { An aggregation of gray-green } \\
\text { shale, papery gray shales, algal } \\
\text { and ostracode limestone, and } \\
\text { buff calcareous sandstone; few } \\
\text { very thin layers of oil shale. } \\
\text { The predominant color is gray. } \\
\text { This member underlies the } \\
\text { oil shale zone of the Green } \\
\text { River formation and com- } \\
\text { prises all of the Green River } \\
\text { present in this area. }\end{array}$ & $\begin{array}{l}600 \\
1,000\end{array}$ & $\begin{array}{l}\text { No recognized min- } \\
\text { eral value. Water } \\
\text { from this horizon } \\
\text { sweeter than from. } \\
\text { beds below. }\end{array}$ \\
\hline & \multicolumn{2}{|c|}{ Wasatch formation. } & $\begin{array}{l}\text { Variegated clay shale, some } \\
\text { sandy, containing occasional } \\
\text { beds of massive sandstone and } \\
\text { numerous thin sandy lenses; } \\
\text { some fresh-water limestone; } \\
\text { locally conglomeratic at base. }\end{array}$ & $280 \div 790$ & $\begin{array}{l}\text { No recognized min- } \\
\text { eral value. }\end{array}$ \\
\hline $\begin{array}{l}\text { Tertiary(?) } \\
\text { (Eocene?). }\end{array}$ & \multicolumn{2}{|c|}{-Unconformity } & $\begin{array}{l}\text { Mainly gray-white sandstone } \\
\text { intercalated with clay shales, } \\
\text { some of which are variegated. } \\
\text { Major erosional unconformity } \\
\text { at base, marked by conglomer- } \\
\text { atic sandstone } 10 \text { to } 40 \text { feet } \\
\text { thick. }{ }^{\circ}\end{array}$ & $155-370$ & $\begin{array}{l}\text { No recognized min- } \\
\text { eral. value }\end{array}$ \\
\hline \multirow{2}{*}{$\begin{array}{l}\text { Upper } \\
\text { Cretaceous. }\end{array}$} & \multirow{2}{*}{ 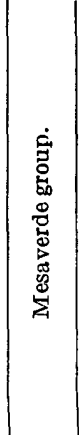 } & $\begin{array}{c}\text { Hunter Can- } \\
\text { yon forma- } \\
\text { tion. }\end{array}$ & $\begin{array}{l}\text { Assemblage of massive brown, } \\
\text { buff, and gray cliff-making } \\
\text { fluviatile sandstone and gray } \\
\text { clay shale. About } 60 \text { percent } \\
\text { sandstone and } 40 \text { percent } \\
\text { shale. }\end{array}$ & 1,400 & $\begin{array}{l}\text { Thin seams of coal } \\
\text { in carbonaceous. } \\
\text { shale near top. No } \\
\text { economic value. } \\
\text { Sandstone proba- } \\
\text { bly too soft for } \\
\text { building stone. } \\
\text { Rather inaccessi- } \\
\text { ble. }\end{array}$ \\
\hline & & $\begin{array}{l}\text { Mount Garfield } \\
\text { formation. }\end{array}$ & $\begin{array}{l}\text { "Barren measures." An assem- } \\
\text { blage of sandstone, shale, and } \\
\text { carbonaceous shale in which } \\
\text { sandstone averages about } 33 \\
\text { percent, shale 51 percent, sandy } \\
\text { shale and shaly sandstone } \\
10 \text { percent, carbonaceous shale } \\
\text { 6 percent. The sandstones are } \\
\text { much like those above but not } \\
\text { so thick or coarse. }\end{array}$ & $405-665$ & $\begin{array}{l}\text { A few thin beds of } \\
\text { coal. are present, } \\
\text { none of minable } \\
\text { thickness. There } \\
\text { are considerable } \\
\text { beds of carbona- } \\
\text { ceous shale. }\end{array}$ \\
\hline
\end{tabular}

a The writer favors placing this sandstone in the Wasatch formation; he believes it is equivalent to the: Ohio Creek conglomerate. 
Summary of exposed rock formations in the Book Cliffs region, Colorado-Con.

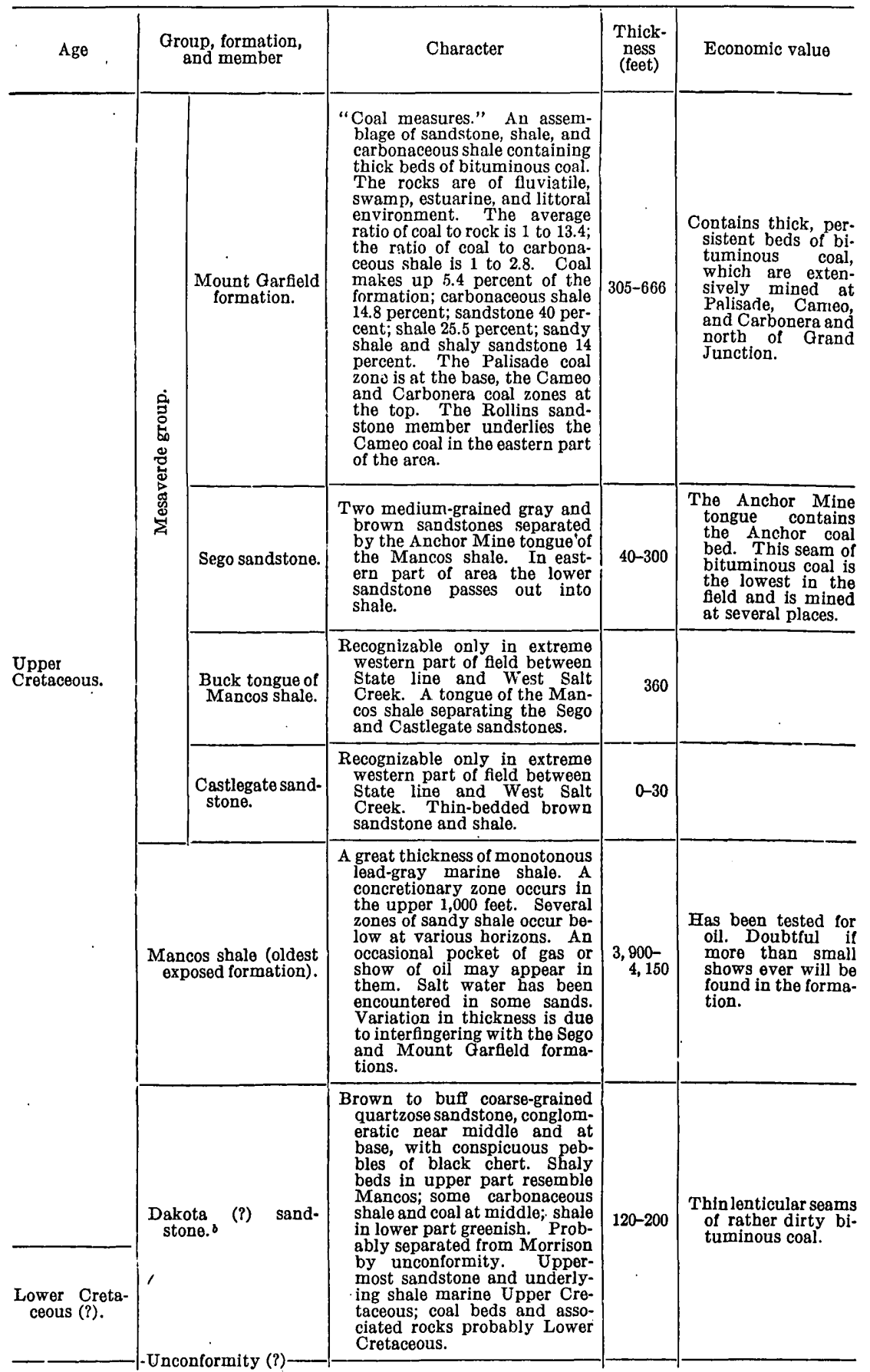

b Rocks not exposed in the Book Cliffs region but exposed in nearby areas or penetrated by wells. 
Summary of exposed rock formations in the Book Cliffs region, Colorado-Con.

\begin{tabular}{|c|c|c|c|c|}
\hline Age & $\begin{array}{l}\text { Group, formation, } \\
\text { and member }\end{array}$ & Character & $\begin{array}{c}\text { Thick- } \\
\text { ness } \\
\text { (feet) }\end{array}$ & Economic value \\
\hline $\begin{array}{l}\text { Cretaceous (?) } \\
\text { (Lower Cre- } \\
\text { taceous?). }\end{array}$ & \multirow{2}{*}{$\begin{array}{l}\text { Morrison formation. }{ }^{b} \\
\text {-Unconformity- } \\
\text { Summerville forma- } \\
\text { tion. }{ }^{b}\end{array}$} & $\begin{array}{l}\text { Mainly light bluish-green and } \\
\text { purplish-red sandy clay shale, } \\
\text { containing thin layers of con- } \\
\text { glomerate, grit, and gray- } \\
\text { white sandstone. Locally, } \\
\text { lenses of limestone. Dinosaur } \\
\text { bones occur in the shale. } \\
\text { Massive sandstones at the } \\
\text { base in some places. }\end{array}$ & 520 & $\begin{array}{l}\text { Gas has been en- } \\
\text { countered by the } \\
\text { wells which have } \\
\text { penetrated upper } \\
\text { and lower sands. }\end{array}$ \\
\hline \multirow[t]{2}{*}{ Upper Jurassic. } & & $\begin{array}{l}\text { Reddish and chocolate-brown } \\
\text { shale. Resembles Morrison } \\
\text { but is more regularly bedded. } \\
\text { Usually included with over- } \\
\text { lying beds by previous authors. }\end{array}$ & 60 & \\
\hline & \multirow{3}{*}{$\begin{array}{l}\text { Entrada sandstone. } \\
\text {-Unconformity (?)-- } \\
\text { Kayenta formation } \\
\text { and Wingate sand- } \\
\text { stone. } \\
\text {-Unconformity- }\end{array}$} & $\begin{array}{l}\text { Orange, brown, and reddish } \\
\text { massive, cross-bedded sand- } \\
\text { stone. May be lighter at top. }\end{array}$ & 125 & \\
\hline Jurassic (?). & & $\begin{array}{l}\text { Tan to brownish-red massive, } \\
\text { cross - bedded cliff - making } \\
\text { sandstone. Portion of Kayenta } \\
\text { formation probably present at } \\
\text { top. }\end{array}$ & 410 & \\
\hline $\begin{array}{l}\text { Upper Trias- } \\
\text { sic. }\end{array}$ & & $\begin{array}{l}\text { Red and maroon sandstone, silt- } \\
\text { stone, and shale, with some } \\
\text { limy lenses. Irregularly bed- } \\
\text { ded. Rests unconformably on } \\
\text { pre-Cambrian complex. }\end{array}$ & 65 & \\
\hline $\begin{array}{r}\text { Pre-Cambrian } \\
\text { (Algonkian?). }\end{array}$ & (b) & $\begin{array}{l}\text { Granite, gneiss, amphibolite, } \\
\text { etc., cut by pegmatites, quartz } \\
\text { veins, and dikes. }\end{array}$ & (?) & . \\
\hline
\end{tabular}

${ }^{\circ}$ Rocks not exposed in the Book Cliffs region but exposed in nearby areas or penetrated by wells.

The columnar sections (pl. 4) measured at various intervals along the cliff front indicate the general nature of the beds exposed from the top of the Mancos shale to the base of the Green River formation and show the number and position of the coal beds. Another section (pl. 5) prepared from well logs and direct measurements shows the general relations and thickness of the concealed rocks. These diagrams show the character of the rocks and the intervals between coal beds or formations only at the localities where the sections were measured but are fairly representative of the rocks elsewhere within the indicated limits. They are supplemented by written descriptions of representative sections and of sections at type localities. A summary of the rock formations is given below.

\section{CONCEALED ROCKS}

\section{PRE-CAMBRIAN}

The floor or basement upon which the sedimentary rocks rest is the peneplaned surface of an extensive igneous and metamorphic complex of pre-Cambrian age. Many rock types are represented in the complex. Among the more common are several varieties of gneissoid granites and porphyritic granites, amphibolites, pegmatites, 
and schist. They are well exposed on the south side of Grand Valley between Shackelton Canyon and No Thoroughfare Canyon, a few miles southwest of Grand Junction. If the red shale in which the Gypsy Oil Co.'s Marie no. 1 well (SE1/4 sec. 9, T. 9 S., R. 101 W.) was bottomed at 3,785 feet is Chinle, then this hole must have come within a very short distance of the pre-Cambrian rocks.

\section{UPPER TRIASSIC \\ CHINLE FORMATION}

The Chinle formation rests unconformably upon the pre-Cambrian rocks. In earlier publications it has been included in the Dolores formation. It consists of some 65 feet of thin, irregularly bedded siltstone, fine-grained silty sandstone, sandstone, shale, and shaly red limestone. The basal part is gritty and locally conglomeratic. The color of the whole is red, but in detail the colors vary from dull brick-red to reddish brown. Locally there may be thin greenish layers or splotches and some grayish beds. The formation crops out in the middle portion of the cliffs on the south side of Grand Valley, a few miles southwest of Grand Junction. The Marie no. 1 well of the Gypsy Oil Co., was bottomed in a red shale, probably Chinle, after penetrating it for 60 feet.

\section{JURASSIC (P) AND UPPER JURASSIC ROCKS}

A group of massive white, red, and light reddish-brown sandstones crop out conspicuously above the Chinle shales on the north flank of Pinyon Mesa, a portion of the Uncompahgre Plateau. In earlier publications they have been considered to represent the $\nmid \mathrm{La}$ Plata ${ }^{32}$ and part of the Dolores formation, but recently they have been identified by C. H. Dane ${ }^{33}$ as the Entrada, Kayenta (?), and Wingate formations of southeastern Utah. The Entrada (middle Upper Jurassic) and the Wingate (base of Jurassic?) are certainly present. The Navajo sandstone (top of Jurassic?) is not present, and the Kayenta, if present is reduced in thickness. This group of sandstones was encountered in the Gypsy Oil Co.'s Marie no. 1 well (NE $1 / 4$ SW $1 / 4$ SE $1 / 4$ sec. 9 , T. 9 S., R. 101 W.), on the Book Cliffs dome, at a depth of 3,190 feet; and in the same company's Garmesa no. 1 well (SW1/4 SW $1 / 4 \mathrm{SE}_{1} / 4$ sec. 5 , T. 8 S., R. 102 W.), on the Garmesa dome at a depth of 3,185 feet. Their total thickness is about 530 feet. It is not possible to differentiate the various units

\footnotetext{
A dagger $(\dagger)$ preceding a geologic name indicates that the name has been abandoned or rejected for use in classification in publications of the U.S. Geological Survey. Quotation marks, formerly used to indicate abandoned or rejected names, are now used only in the ordinary sense.

${ }^{33}$ Personal communication.
} 
from the logged descriptions, but the upper 125 feet appears to loe typical Entrada.

The Upper Jurassic Summerville formation of southeastern Utah is an assemblage of red to reddish-brown shales with some thin intercalated sandstones and limestones. The formation has in past publications been included, with the overlying Morrison, in the $\nmid$ McElmo formation. However, in southeastern Utah, C. H. Dane, of the Geological Survey, in 1927 traced the Summerville eastward to Westwater station on the Denver \& Rio Grande Western Railroad and found that it continues into western Colorado. The 60 feet of red shales, limy shales, and thin limestones encountered by the drill in the Gypsy Oil Co.'s Marie no. 1 well between the depths of 3,130 and 3,190 feet is identified as the Summerville formation. About 40 feet of similar strata were found in the Gypsy Oil Co.'s Garmesa no. 1 well. Though the lithology closely resembles that of the Morrison beds, the strata are thinner and more regular.

\section{CRETACEOUS (?) SYSTEM}

\section{MORRISON FORMATION}

The Morrison formation is exposed as a narrow strip along the foot of the cliffs that bound Pinyon Mesa on the north. It roughly parallels both the course of the Colorado River, which it crosses a few miles south of Loma, and the trend of the Book Cliffs. The Gypsy Oil Co.'s Garmesa no. 1 well entered the formation at a depth of 3,194 feet and continued in it for 395 feet; the same company's Marie no. 1 well penetrated the entire formation, whose thickness on the Book Cliffs dome appears to be about 520 feet.

The upper portion consists of an alternation of light bluish-green and purplish-red sandy shales. Though resistant to the pick they yield easily to the forces of erosion; thus where unprotected by the resistant ledges of Dakota(?) sandstone they are expressed topographically as badlands. Thin layers of conglomerate, grit, and gray-white sandstone are also present. In some localities fragments of dinosaur bones are numerous, and near Grand Junction several more or less complete specimens have been collected..$^{34}$ Invertebrate fossils are rare, only a species of Viviparus having been found. The basal part of the formation is characterized by a greater abundance of sandstone and by limy strata. In favorable localities the sandstones at the top of the formation and to some extent those lower down have yielded considerable quantities of natural gas. The brown sandstones 30 to 50 feet thick which occur at the base of the formation in the Gypsy Oil Co.'s Garmesa no. 1 well may be the

\footnotetext{
${ }^{84}$ Rigg.s, E. S., The dinosaur beds of the Grand River valley, Colo.: Field Columbian Mus. Geol. Ser., vol. 1, no. 9, pp. 267-274, 1901.
} 


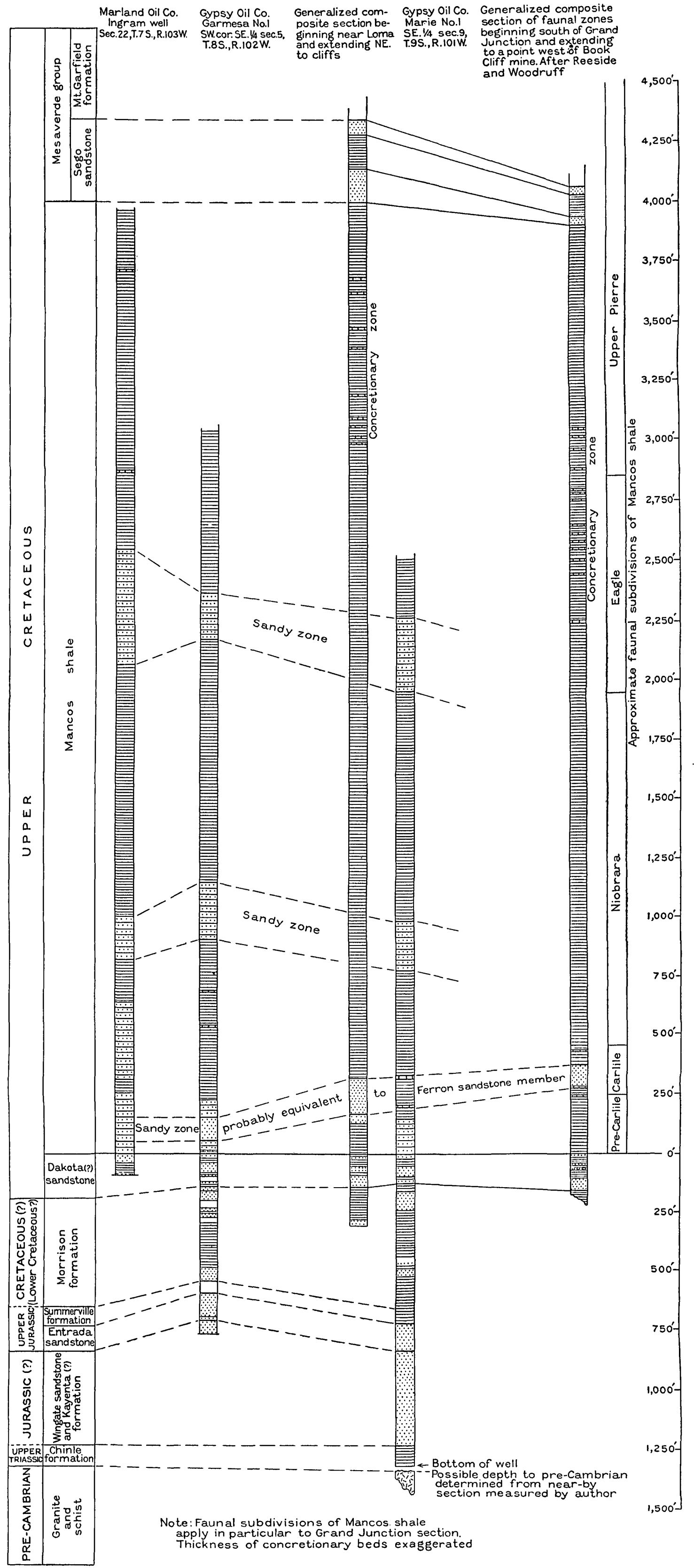

EXPLANATION 
equivalent of the Salt Wash sandstone member of southeastern Utah. The sandstones thin to the east and are not present in the Gypsy well on the Book Cliff dome.

\section{CRETACEOUS SYSTEM}

\section{DAKOTA (?) SANDSTONE}

The Dakota (?) sandstone forms low cuesta ridges which roughly parallel the Book Cliffs at a distance of about 12 miles to the south. These are particularly conspicuous in the vicinity of Mack. The formation is characterized by variability as a unit and in the individual strata. Its thickness at the surface ranges from 25 feet to about 200 feet, and where penetrated by drill holes from 120 to 200 feet, but this maximum may include some of the higher Morrison sandstones.

In most localities a threefold lithologic division is apparent. The upper division consists of a massive brown to buff medium-grained quartzose sandstone 20 to 45 feet thick. It is of marine origin and is transitional into the Mancos shale through a series of thin sandstones and shales, which may be highly carbonaceous. Locally, as in the Midwest Refining Co.'s Hayden no. 1 well, in the SE1/4 SE1/4 SW1 14 sec. 36, T. 7 S., R. 103 W., it is not present. Fossils are extremely rare, and those found are of Upper Cretaceous age. Inoceramus aff. I. belvuensis Reeside and Acanthoceras aff. $A$. rhotomagense Defrance have been reported from this part. This sandstone is underlain by gray shale, which is much like the overlying Mancas and contains some thin coarse sandstone and more rarely basal conglomerate. The shale is 20 to 30 feet thick and contains the same fossils as the sandstone.

Under this upper unit usually lies the middle zone of carbonaceous shale, which contains coals of low rank and grade, associated with some layers of sandstone, over much of the region. The lower part of this unit has yielded fossil plants that are interpreted as of Lower Cretaceous age. ${ }^{95}$ The lowermost lithologic division of the Dakota (?) is not everywhere present. It is characterized by greenish sandy shales which closely resemble those of the underlying Morrison and a massive basal sandstone which is much like that at the top of the formation but includes many lenses of chert-pebble conglomerate.

As the vertebrate fossils in the upper unit are of early Upper Cretaceous age,$^{36}$ and the plant fossils in the middle unit are interpreted as Lower Cretaceous, there are thus two chronologically dis-

${ }^{85}$ Berry, E. W., A new Matonidium from Colorado, with remarks on the distribution of the Matoniaceae: Torrey Bot. Club Bull., vol. 46, pp. 285-294, 1919.

${ }^{30}$ Reeside, J. B., Jr., An Acanthoceras rhotomagense fauna in the Cretaceous of the Western Interior: Washington Acad. Sci. Jour., vol. 17, pp. 453-454, 1927.

50646-34-3 
tinct elements in the Dakota (?) sandstone. The lower, nonmarine element is probably considerably older; the upper element is interpreted as comprising the basal deposits of an advancing sea, which are progressively younger to the west.

The coals in the Dakota (?) formation; though of bituminous rank, are not of commercial importance at the present time. They are thin, many have a high ash content, and they grade laterally into bone and carbonaceous shale. In some localities they are not present, Their general character is. so unfavorable that, in comparison with the coals in the Book Cliffs, they hardly deserve mention. Nevertheless, because of their accessibility, some abortive efforts have been made to mine them.

The Dakota (?) sandstones have been the objective of all the drilling campaigns that have been carried on in this region in the search for oil. Five of the six deep holes that have been drilled enter it, and two have passed through it to the underlying formations. Considerable amounts of natural gas have been obtained at different horizons within the Dakota (?), but very few shows of oil have been found. Nevertheless, this formation is still of economic interest as a possible reservoir rock where it is favorably situated with respect to structure and source rocks.

\section{EXPOSED ROCKS}

\section{CRETACEOUS SYSTEM}

\section{UPPER CRETACEOUS SERIES}

\section{MANCOS SHALE}

The Mancos shale is a thick but rather simple lithologic unit. No persistent stratum or distinctive lithologic group exists which can be used for the subdivision of the formation or for regional areal mapping. The best estimates of the thickness are those obtained from the logs of the deeper oil wells, supplemented by measured sections; they range from 3,908 to 4,150 feet. The average of four careful estimates and measurements is 4.020 feet, and this figure is believed to be correct within 50 feet. The previously published estimate of the thickness in this region is 3,000 feet. $^{37}$

The Mancos shale is exposed in a wide belt in the Book Cliffs coal field and in the broad terraced floor of Grand Valley. As a whole, the exposures are characteristically barren of vegetation and somber in color. The portion of the shale that is revealed in the cliffs is light ash-gray, and locally it may have a slight bluish tone. Where covered with wash from the overlying sandstones the shale assumes a gray-buff color. The lower portion of the Mancos

\footnotetext{
${ }^{87}$ Lee, W. T., Coal fields of Grand Mesa and the West Elk Mountains, Colo.: U.S. Geol. Survey Bull. 510, p. 25, 1912.
} 
usually appears dull lead-colored to gray-black. The weathered surface of the shale is much fretted and pitted by rain erosion and consists of a cracked and fissured layer of tough structureless clay a few inches to several feet thick. When wet this surficial material becomes very sticky and slippery and is almost impervious to water. Over some small areas the surface is coated with white efflorescent patches of "alkali." The unweathered rock is a sandy and in places even gritty, irregularly bedded, more or less fissile marine shale.

The general monotony of this great thickness of shale is broken by a series of minor variations in the form of sandy zones. Several hundred feet above the base and extending to a height of at least 500 feet above the base in some places is an irregular group of thin-bedded and platy brown sandstones and sandy shales which is roughly equivalent to the Ferron sandstone member of Castle Valley and adjacent regions in eastern Utah, ${ }^{38}$ but the application of that name here is of little utility. Small showings of gas and oil have been obtained at this horizon in some of the wells, and petroleum geologists have referred to it as the Frontier sand. Topographically this part of the formation is expressed as a low ridge north of and parallel to the Dakota (?) cuesta.

Three other similar sandy zones occur in the lower 2,800 feet of the formation. The lowest of these is 50 to 200 feet thick and lies 800 to 900 feet above the top of the Dakota (?) sandstone. The base of the next higher occurs approximately in the middle of the Mancos shale, 2,000 to 2,100 feet above the base; its thickness ranges from 300 to 400 feet. The highest sandy zone is 600 feet above the top of the middle zone, and its thickness ranges from 100 to 200 feet. All are more or less inconspicuous topographically. Owing to weathering and disintegration of the sandy layers the surface of the enclosing shale is usually tan or buff. Fossils seem more abundant in the sandy beds than in the finer-grained shaly layers.

The upper 1,000 feet of the Mancos shale is characterized by the presence of groups of thin, irregular layers and overlapping lenses of calcareous sandstone, concretionary beds, and limestones. The thickness of the small groups ranges from 4 or 5 feet to 15 feet, and the interval between them from 25 to 200 feet. The average interval approaches 90 feet, and that between adjacent beds is usually regular. These beds are much more resistant than the enclosing shales and crop out as low brown ledges, or more rarely as short, steep cliffs facing away from short dip slopes. The concretions range in size from small septaria the size of the hand to

${ }^{8 s}$ Clark, F. R., Economic geology of the Castlegate, Wellington, and Sunnyside quad. rangles, Carbon County, Utah: U.S. Geol. Survey Bull. 793, p. 13, 1928. Spieker, E. M., and Reeside, J. B., Jr., Cretaceous and Tertiary formations of the Wasatch Plateau, Utah: Geol. Soc. America Bull., vol. 36, p. 438, 1925. 
large ovoid masses 8 or 9 feet in diameter and 5 or 6 feet thick. Some beds are merely aggregates of these concretions, with the intervening spaces occupied by calcareous sandstone and shale. The fresh material in most concretions and lenses is a hard, dense dark bluish-gray impure limestone. A few are ferruginous. Some faces exhibit networks of small calcite veins. Weathered rock becomes $\tan$ to reddish brown and disintegrates. The surface of the shale in many places is littered with small angular fragments of concretionary material. Many of the larger concretions show spheroidal weathering.

Although by nature not widely persistent, these concretionary layers make excellent local key beds for use in determining details of structure, because of their regularity of interval and the ease with which they may be traced. The structure of the High Line dome and of the part of the Garmesa dome south of the outcrop line of the Sego sandstone was worked out through the use of these beds. (See fig. 4 and pl. 11.)

Both upper and lower boundaries of the Mancos shale are gradational. The lower is regular and has been referred to in connection with the Dakota (?) sandstone. The upper boundary is of particular interest in that it marks the beginning of the change from a marine to an estuarine and continental environment; it well illustrates the nature of the intertonguing of marine shales and sandstones, here probably littoral rather than offshore marine, and has a pronounced stratigraphic rise toward the east. From the UtahColorado boundary eastward for 38 miles the top of the Mancos shale is marked by the base of the lower member of the Sego sandstone. Although the Mancos shale and the sandstone are perfectly conformable over the entire distance, the contact between them is undulating, and a maximum relief of 90 feet has been noted. In the northwest corner of T. 10 S., R. 99 W., the lower sandstone of the Sego feathers out into the Mancos shale, and the lithologic boundary used as the top of the Mancos shale thus moves upward about 250 feet to the base of the upper member of the Sego. Westward from this place the two sandstones are separated by a wedge-shaped body of shale, for the most part marine, which is here termed the Anchor Mine tongue of the Mancos shale. It contains the Anchor coal zone, which is exposed at the Anchor mines. The contact at the base of the upper sandstone of the Sego is also gradational and much like that of the lower sandstone. It can be observed in sec. $28, \mathrm{~T} .12 \mathrm{~S}$., R. $97 \mathrm{~W}$., about 23 miles to the southeast, where, according to Boyer, ${ }^{39}$ the upper sandstone feathers out into the Mancos shale, and the top of the Mancos shale again steps upward 350 feet to the base of the

${ }^{89}$ Boyer, W. W., unpublished report. 
massive white Rollins sandstone member. The boundary continues eastward at this horizon into the Crested Butte-Anthracite region. Thus in two steps over the relatively short distance of 61 miles the top of the Mancos rises 600 feet stratigraphically. This behavior need not be considered unusual if the character of the boundary farther west is recalled. From the base of the Star Point sandstone in the Wasatch Plateau to the southwest end of Grand Mesa, a distance of about 180 miles, the boundary rises 2,350 feet stratigraphically by a series of six great steps.

The Mancos shale of the eastern Book Cliffs field is equivalent in age to the Benton and Niobrara of the Colorado group and to beds well up in the middle of the Montana group. The stratigraphic range upward and the thickness are thus considerably greater in this field than in the type locality. ${ }^{40}$

\section{MESA VERDE GROUP}

\section{GENERAL RELATIONS}

The term "Mesaverde" was applied originally in southwestern Colorado to a series of coal-bearing sandstones and shales enclosed between marine shales and constituting the middle of the Montana group. In its present extended usage over the southern Rocky Mountain region it has at many localities been applied to coal-bearing strata that are not strictly equivalent to the original Mesaverde group of southwestern Colorado, and the name has retained only a rather loose time significance. In the Book Cliffs of Colorado and Utah it is used to designate a lithologic group of buff to yellow-brown sandstone intercalated with soft gray shales, which contain beds of bituminous coal at one or more horizons and are underlain by thick beds of massive littoral sandstone that rest upon the marine Mancos shale and are in part contemporaneous with a part of the Mancos. There are no overlying marine shales. In eastern Utah, near the west end of the Book Cliffs, the name "Mesaverde" has been applied to a group of three formations-namely, ${ }^{41}$

Price River formation:

Shale and sandstone member (non-coal-bearing).

Castlegate sandstone member.

Blackhawk formation:

Coal-bearing member.

Aberdeen sandstone member.

Star Point sandstone.

\footnotetext{
${ }^{40}$ Cross, Whitman, and Purington, C. W., U.S. Geol. Survey Geol. Atlas, Telluride follo (no. 57), p. 4, 1899 .

11 Clark, F. R., Economic geology of the Castlegate, Wellington, and Sunnyside quadrangles, Carbon County, Utah: U.S. Geol. Survey Bull. 793, pp. 11-12, 1928.
} 
In the Grand Mesa region of central western Colorado the Mesaverde rocks have been treated as a formation with the following members : ${ }^{42}$

Mesaverde formation:

Undifferentiated deposits constituting bulk of Mesaverde.

Paonia shale member.

Bowie shale member.

Rollins sandstone member.

Reeside ${ }^{43}$ has indicated that neither set of names applies satisfactorily to the area of the eastern Book Cliffs between Green River, Utah, and Palisade, Colo.; and Boyer ${ }^{44}$ has recently shown that only one of Lee's names is useful in the western portion of Grand Mesa. At least the lower Mesaverde strata in the Book Cliffs of Colorado are known to be the direct equivalent of the Price River formation of central Utah. ${ }^{45}$ The upper strata more probably are somewhat younger and thus homogenetic rather than chronologic equivalents. Both structural and paleontologic evidence indicate that in Utah the Price River beds are all or chiefly later than the typical Mesaverde.

The basal division of the Price River formation in Utah is the Castlegate sandstone member. This unit is practically nonexistent in Colorado. At the State line it is represented by some 30 feet of thin sandstone, and at the mouth of West Salt Creek a layer of calcareous concretionary sandstones occurs at the Castlegate horizon-the extreme eastern featheredge of the massive sandstones that characterize the unit in Utah. The name "Buck tongue" has been applied by Fisher ${ }^{45}$ in Utah to the tongue of Mancos shale which separates the Castlegate sandstone from the Sego sandstone, but the name cannot possibly be applied east of West Salt Creek in Colorado.

The lowest mappable division of the Mesaverde group in Colorado is termed the "Sego sandstone", this name having been applied to these beds in Utah by Fisher, who treats them as a member of the Price River formation. The coal-bearing rocks and associated strata above the Sego sandstone are here named "Mount Garfield formation", as Mount Garfield, a conspicuous topographic feature near the east end of the area here described, has been carved from them. The formation is essentially equivalent to the strata near Palisade which were misidentified by Lee as the Bowie and Paonia shale members of the Mesaverde formation, and to the

${ }^{42}$ Lee, W. T., Coal fields of Grand Mesa and the West Elk Mountains, Colo.: U.S. Geol. Survey Bull. 510, p. 19, 1912.

${ }_{43}$ Reeside, J. B., Jr., personal communication.

44 Boyer, W! W., op. cit.

45 Fisher, D. J., The Book Cliffs coal field in Emery and Grand Counties, Utah : U.S. Geol. Survey Bull. 852 (in preparation). 
Neslen member and the lower part of the Farrer member of the Price River formation in eastern Utah as defined by Fisher. The upper division of the rocks mapped as Mesaverde group in this report is herein termed the "Hunter Canyon formation," from the type locality. The Price River age of this formation is, however, a matter of doubt, and it has therefore been considered unwise to extend the name "Price River formation" into western Colorado. The Hunter Canyon rocks are certainly younger than the greater part of the Price River formation and older than the Wasatch; thus they may possibly represent part of Lance and Fort Union time.

All three of these formations are perfectly conformable. The Hunter Canyon and Mount Garfield formations grade into each other so insensibly that no definite line of separation, as valid at one locality as at another, can be chosen. Thus the boundary that has been placed between them is purely arbitrary and has been assigned more for the convenience of lithologic description than for precise stratigraphic subdivision. In eastern Utah Fisher has applied the name "Tuscher formation" to another group of strata that are not satisfactorily identified in western Colorado. If present here, the Tuscher strata form the upper portion of the Hunter Canyon formation. It is admitted that there are certain slight differences in lithology, weathering, and color between the upper and lower sandstones of the Hunter Canyon formation, but the distinction is one of gross ensemble and becomes less evident at close view. As the separation of the two sandstones would involve the placement of an unmappable, arbitrary, and difficultly recognizable boundary in a portion of the Colorado section still famed because of earlier disputes, it is thought best to make no effort toward further subdivision of the Hunter Canyon formation in that State.

The lithologic composition diagrams of figure 3 indicate some of the gross differences between the Mount Garfield and Hunter Canyon formations. The Sego sandstone is not included, as it is so distinctive that it cannot be mistaken. The Hunter Canyon is first compared with the Mount Garfield formation as a whole; then the subdivisions of the Mount Garfield are likewise compared. The horizontal distance to which the data pertain, about 50 miles, is not great enough to show the eastward transition from fluviatile to coastalswamp to littoral-marine deposits. The degree of contrast between the various diagrams indicates the varying success with which the mappable differences were noted in the field.

Because the Mesaverde rocks are of littoral, estuarine (brackish water), and continental (fluviatile and coastal swamp) origin, fossils are most uncommon. Fortunately the upper and lower boundaries are quite distinct. The upper boundary is an erosional uncon- 
formity of considerable magnitude, which in most places is marked by an overlying basal conglomerate or conglomeratic sandstone. The lower boundary is the top of the Mancos shale, which can usually be
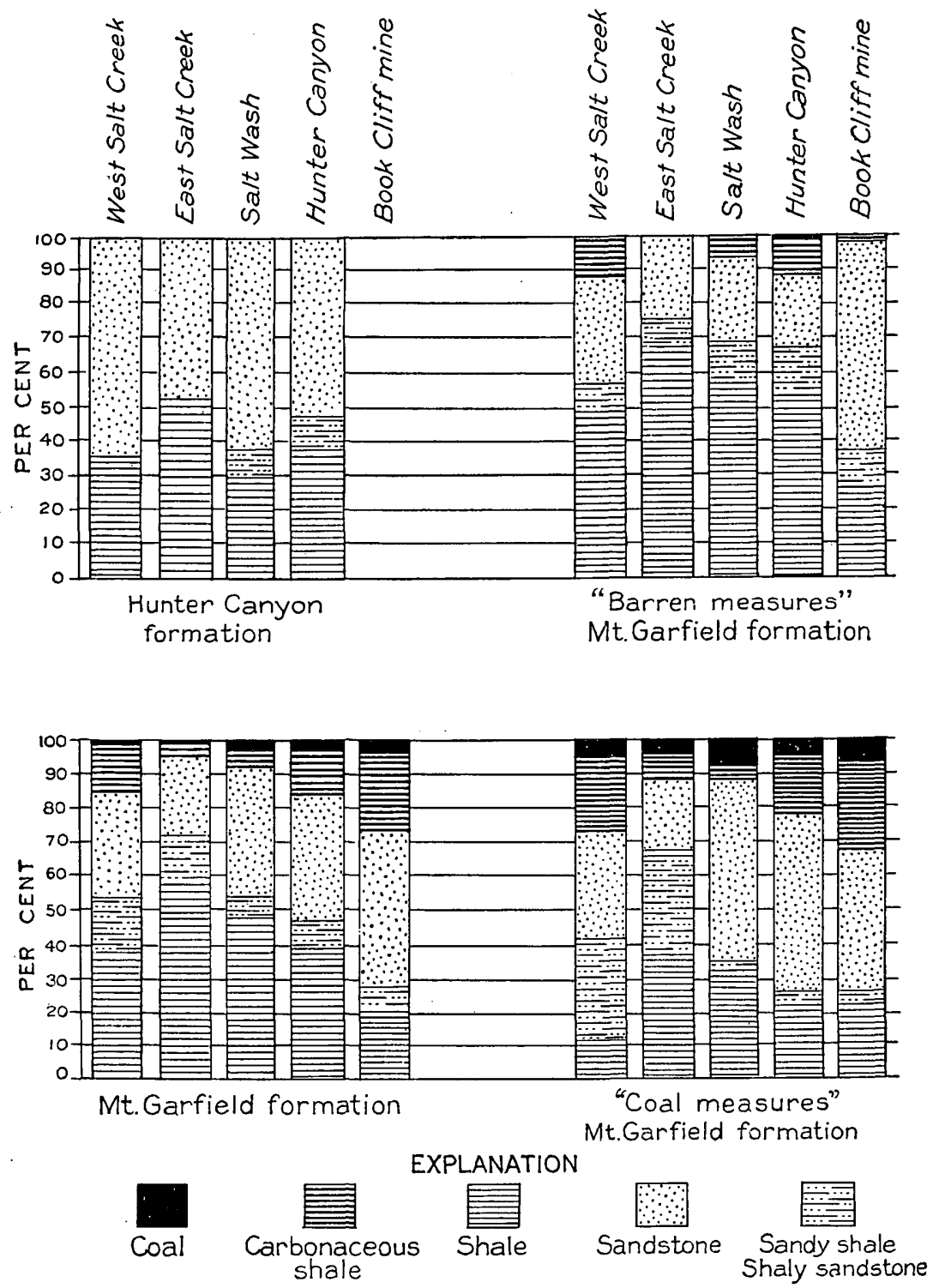

Frgure 3.-Lithologic composition of Mount Garfield and Hunter Canyon formations.

placed within a few feet. These strata range in thickness from 1,520 to 2,530 feet.

\section{SEGO SANDSTONE}

The boundary between the Mancos shale and the overlying Sego sandstone marks the transition from a marine shale to deposits of 


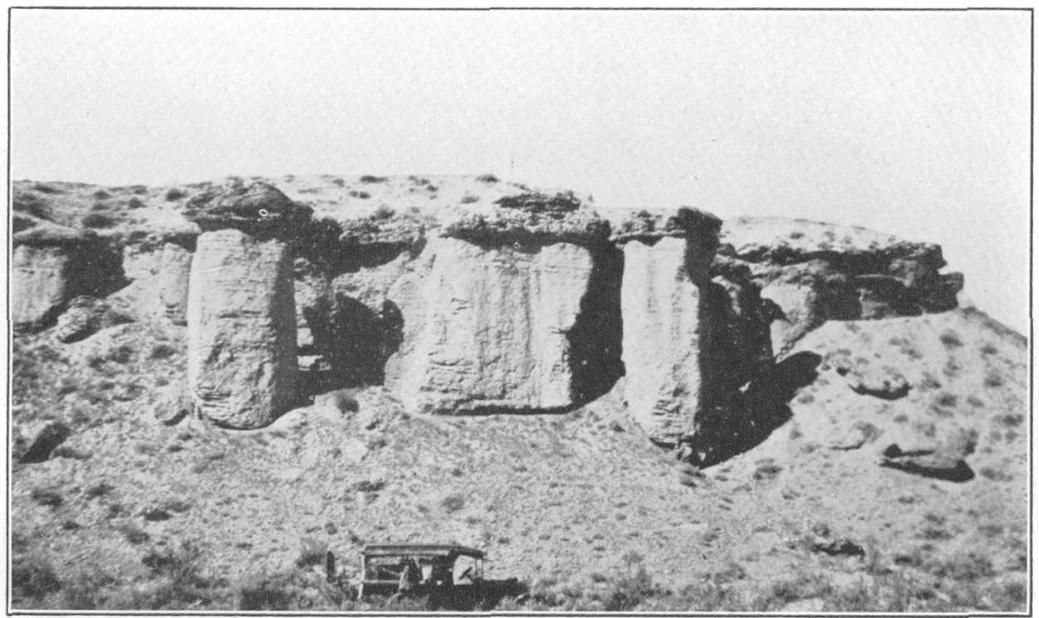

A, INDURATED SAND AND GRAVEL CAPPING LOWER DESTRUCTIONAL TERRACE CARVED ON MANCOS SHALE IN SW1/4 SEC. 10, T. 8 S., R. 104 W.

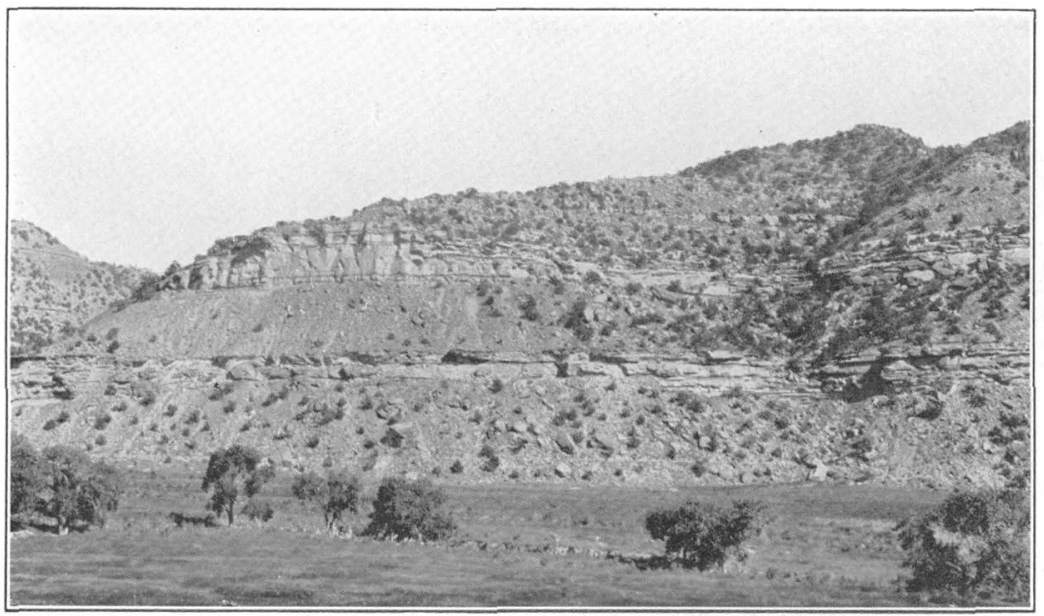

$B$, EXPOSURE OF SEGO SANDSTONE ON EAST WALL OF MOUTH OF EAST SALT CREEK CANYON.

From the bottom up the strata consist of the top of the Mancos shale, the lower member of the Sego sandstone, the Anchor Mine tongue of the Mancos shale, the upper member of the Sego sandstone, and the Mount Garfield formation. 


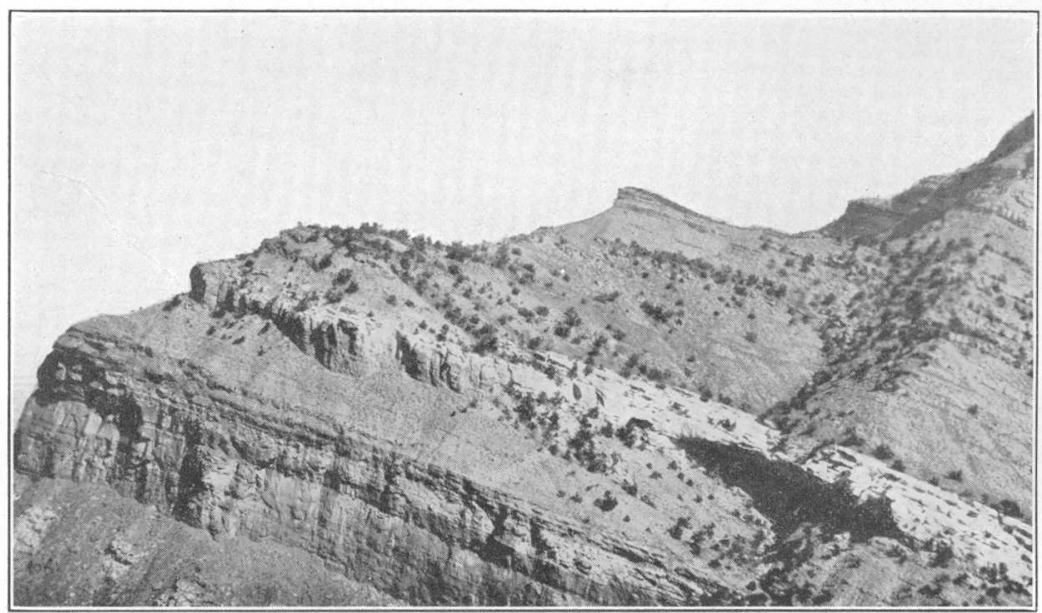

A, TYPE SECTION OF MOUNT GARFIELD FORMATION ON WEST WALL OF CANYON AT BOOK CLIFF MINE IN SEC. 4, T. 1 N., R. 1 E.

The sandstone in the lower left corner is the upper member of the Sego. The Palisade coal crops out just above it, at the base of the vertical sandstone wall. The massive white Rollins sandstone is conspicuous. The outerop of the Cameo coal, which overlies it, is burned.

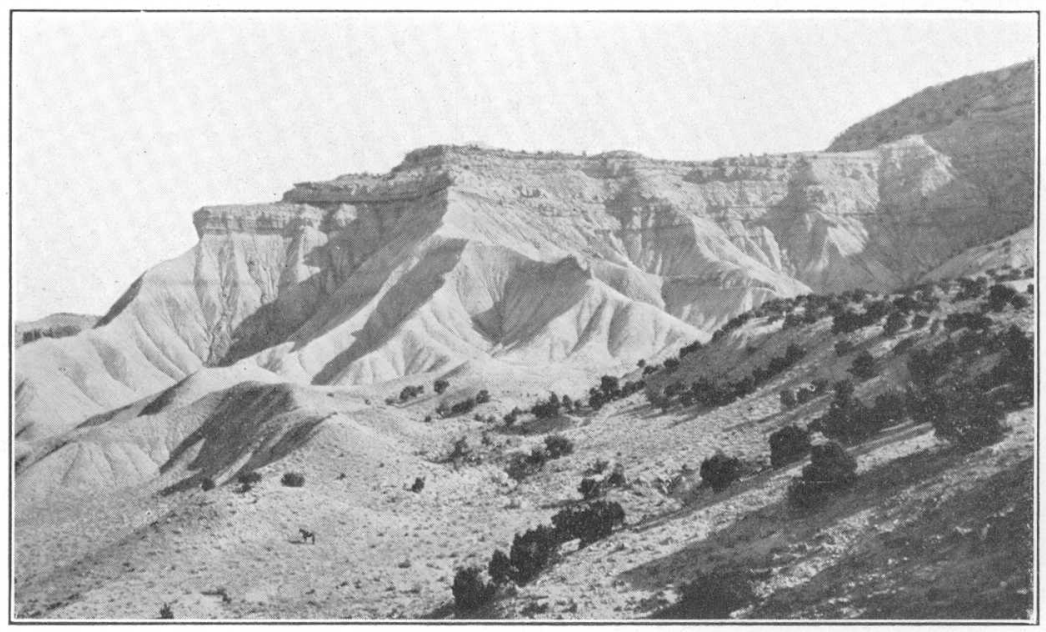

$B$, OUTCROP OF ANCHOR COAL ON THE CLIFF FACE IN SEC. 13, T. 8 S., R. 102 W.

The lower member of the Sego sandstone appears in profile. The sculpturing of the Mancos slope is typical. The horse in the foreground shows the scale. 
the littoral zone. The sandstone in part rests conformably upon the shale and in part intertongues with it. The upper surface of the sandstone is relatively smooth and is the most persistent, easily recognizable stratigraphic horizon in the region. Over the greater part of the field the outcrop is usually a bold vertical cliff, which renders the overlying Palisade coal zone inaccessible except at the heads of reentrants where streams have breached the wall. East of sec. 30, T. 8 S., R. 101 W., the outcrop can best be represented on the map by a line. West of this locality the outcrop widens, especially upon the noses of spurs. The top of the sandstone is represented on the map by the line that marks the outcrop of the Palisade coal zone.

The type locality of the Sego sandstone is the village of Sego, in the Book Cliffs of Utah, where it consists of a single unit of sandstone, but in the Book Cliffs of Colorado the Sego is split by the Anchor Mine tongue of Mancos shale, and the sandstone above is designated the "upper sandstone" or "upper member", and the sandstone below, the "lower sandstone" or "lower member."

LOWER MEMBER OF SHGO SANDSTONE

The top or eastern featheredge of the lower member of the Sego sandstone lies in contact with the base of the Anchor Mine tongue in sec. 12 , T. 10 S., R. 100 W. Westward this lower sandstone thickens rapidly, attaining a thickness of 90 feet at Hunter Canyon. Near the mouth of East Salt Creek (pl. 6, B) it reaches its maximum thickness of 110 feet and is typically developed; there it is a little less massive than to the west and more massive than to the east. Both upper and lower boundaries are markedly transitional and are more irregular than those of the upper member of the Sego. The nature of the lower boundary has been mentioned in detail in connection with the Mancos, as has also the base of that portion of the upper member of the Sego which overlaps the lower member. The general lithology of the lower member is given in the following stratigraphic section:

\section{Section at East Salt Creek}

Lower member of Sego sandstone:

Ft. in.

Sandstone, massive, medium grained, buff. Solution pits and cavities on weathered surfaces_--

Sandstone, less massive, beds somewhat thinner and separated by 2 to 6 inch partings. Grain coarser than that of enclosing beds $15-20$

Sandstone, massive, fine to medium grained, yellowbrown on fresh surfaces; weathers buff. Locally cross-bedded. An impure (arkosic) quartz sand_ 10-12 
Lower member of Sego sandstone-Continued.

Ft. in

Sandstone, sandy shale, and clay shale, in thin beds, intercalated. Sandstone gray, fine to medium grained, grading toward sandy shale; built up of thin laminae; cross-bedding on a very small scale; bedding surfaces dotted with small fragments of carbonaceous matter; contains mud lumps and pellets; thickness ranges from 4 inches to $2 \frac{1}{2}$ feet; conspicuous lenses some of which are hard, dense, yellow-brown, and calcareous. Sandy shale and clay shale part the sandstone; both thinly laminated. Sandy shale cross-bedded on small scale; sandy portion fine to medium grained. Clay shale bluish gray but may develop yellow-brown and red concretionary bodies by weathering; most abundant at the top of this zone; fissile carbonaceous films on bedding surfaces

Transitional zone to Mancos shale:

Shale, sandy, bluish to greenish gray

Sandstone, hard, massive, medium grained, gray--

Sandstone, in thin layers $1 / 4$ to $1 / 2$ inch thick------

Shale, sandy, bluish to greenish gray

Sandstone, hard, massive, medium grained, gray---

Typical Mancos shale.

\section{ANCHOR MINE TONGUE OF MANCOS SHALE}

The Anchor Mine tongue is one of the three westward-projecting tongues of Mancos shale that interfinger with the basal Mesaverde strata. Its base or east end lies in sec. 12, T. 10 S., R. 100 W., and in that vicinity it has typical Mancos lithology. Westward it changes from dark-gray sandy marine shale into a facies of thin-bedded sandstone and carbonaceous materials representing deposition in shallower waters near shore. Near the mouth of Hunter Canyon, where it separates the upper and lower members of the Sego sandstone, its tonguelike character becomes evident. This tongue of the Mancos shale has an unusual form. It thins westward from the vicinity of Hunter Canyon to the vicinity of Salt Wash, where it reaches a minimum. Westward from the constriction at this locality it thickens rather abruptly, reaches a maximum in sec. 10, T. 8 S., R. 102 W., and then thins again rather gradually as it extends westward into Utah, where it loses its identity. (See pl. 4.)

\section{Section of Anchor Mine tongue of Mancos shale at Hunter Canyon}

Sandstone.

Calcareous concretionary layer, dense, blue-gray ; weathers reddish brown

Ft. in.

Shale, carbonaceous, chocolate-brown, with thin lenses of a brilliant black coaly substance 


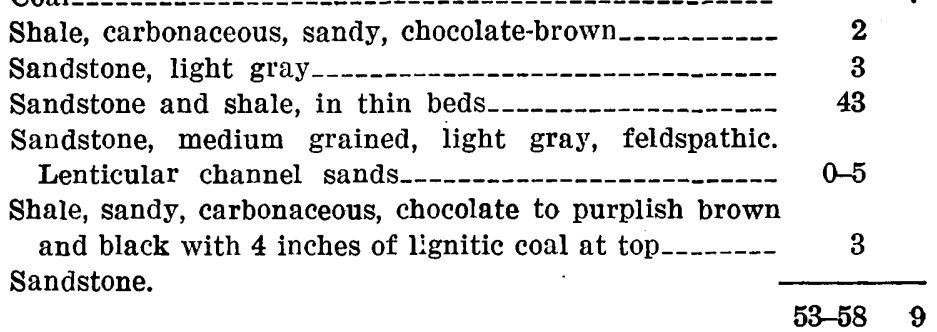

The sandy facies become accentuated as the tongue thins westward. 'The thinning is apparently due to nondeposition of the basal portion. The basal beds are replaced by the lower member of the Sego sandstone, whose upper surface rises stratigraphically westward as the Anchor Mine tongue of the Mancos thins. A lenticular bed of bituminous coal (pl. $7, B$ ) occurs near the top of the tongue over the same area. This has been named the Anchor coal bed, from the Anchor mines opened in it. The shale tongue is exposed at the Anchor mines.

The character of the Anchor Mine tongue where it is thinnest is shown by the stratigraphic section given below.

Section at northwest corner of sec. $30, T .8$ S., R. 101 W.

Upper member of Sego sandstone.

Anchor Mine tongue of Mancos shale:

Shale, highly carbonaceous, chocolate-brown.-----

Shale, carbonaceous, light chocolate-brown-------

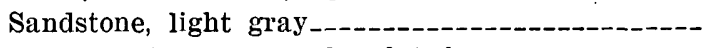

Shale, carbonaceous, chocolate-brown -.--_--.---

Concretionary layer, calcareous and ferruginous.--

Shale, carbonaceous, chocolate-brown

Sandstone lens, gray, massive

Shale, carbonaceous, gray to brown; mineral charcoal-_-_-

Clay, with sandstone nodules at top

Anchor coal :

Bone

Coal

Shale, carbonaceous, chocolate-brown

Ft. in.

8

5

1

58

1

11

Bone

Coal

Shale, carbonaceous, chocolate-brown; weathers gray ; hard and dense, highly jointed; grades laterally into sandy layer 
West of the mouth of Salt Wash Canyon the thickness of the Anchor Mine tongue increases so rapidly that it is nearly trebled within 4 miles.

In the mouth of East Salt Wash Canyon (pl. 6, B) the relation of the Anchor Mine tongue to the upper and lower members of the Sego sandstone is as definite and well exposed as anywhere else along the cliffs. The character is completely different from that a few miles to the east, as is indicated by the stratigraphic section:

Section of Anchor Mine tongue of Mancos shale in East Salt Wash Canyon

Shale, gray clay, sandy, containing at short intervals thin beds (maximum 18 inches) of fine to medium grained gray sandstone, some of which is thinly laminated and cross-bedded.-

Shale, gray sandy clay 30

Shale, gray clay, sandy, containing thin beds of fine to medium grained gray sandstone.

Feet

Toward the State line the Anchor Mine tongue becomes thinner and more sandy and loses its shaly character, and a few miles beyond the State line it disappears altogether. Where it loses its identity the upper and lower members of the Sego sandstone unite and form a single massive unit about 225 feet thick.

UPPER MEMBER OF SEGO SANDSTONE

In the eastern part of the Book Cliffs coal field the upper member of the Sego sandstone at a distance appears as a massive gray cliff somewhat lighter than the Mancos shale below. Closer inspection shows that it consists of a great number of thin, irregular, or platy beds of sandstone, usually laminated and in many places crossbedded. It becomes more and more massive toward the west. The rock is medium-grained, has a sugary texture, and is soft and friable. It is composed largely of quartz, but in some localities an abundance of. ferromagnesian minerals gives it a grayish tone. Some red jasper-like grains are also present. Throughout most of its extent the upper 10 or 15 feet is lighter in color than the underlying buff and brown strata. The variations in thickness that are so apparent are due to lateral changes in lithology at the base and to lack of definition of the top of the Mancos.

In passing from east to west along the Book Cliffs the upper sandstone first appears at the top of the Mancos shale in the vicinity of sec. 28 , T. 12 S., R. $97 \mathrm{~W}$. It is hardly recognizable as a unit and consists of a succession of platy beds of calcareous sandstone a few inches to 2 or 3 feet in thickness, which contains numerous fucoid remains and Inoceramus shells. At the Riverside-Farmers mine, a 
few miles to the northwest, the sandstones have thickened to a rather definite unit about 40 feet thick. Boyer gives the thickness as 100 feet below the Garfield mine, but a few miles to the west, below Mount Garfield, the thickness is again only 35 feet. The lithologic character at Mount Garfield is shown by the following section:

\section{Section at Mount Garfield}

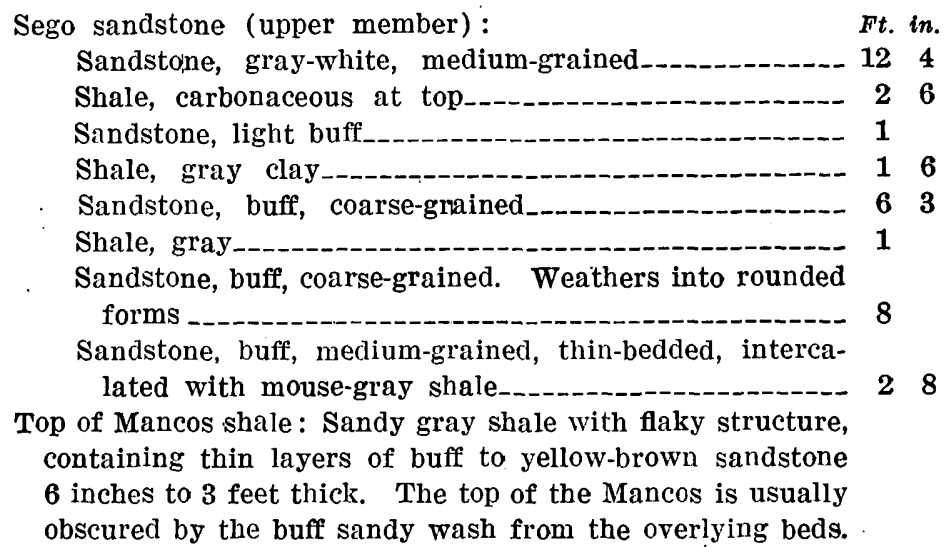

Near the Book Cliff mine the unit is more massive in appearance but still is relatively thin, comprising 31 feet of gray-white sandstone. A mile north of this locality, at the northwest corner of sec. 7, T. 10 S., R. 99 W., a detailed section shows a surprising increase in thickness. The same massive gray-white sandstone unit that was noted at the Book Cliff mine is present, and below it there is an additional 73 feet of sandstones and sandy shales, with the sandstones predominating. These beds are underlain by a shaly zone about 30 feet thick, characterized by the rounded, lumpy structure of the shale and by an abundance of carbonaceous material. At the base of the shale there is $\mathbf{1 1}$ feet of thinly laminated, medium-grained massive gray sandstone, which may perhaps be a featheredge of the lower member of the Sego sandstone.

From this place westward along the face of the cliffs to Hunter Canyon the upper sandstone shows but little variation in thickness and becomes more massive and of greater prominence as a basal element in the Mesaverde cliffs. The upper 25 feet resembles the equivalent portion at the localities previously mentioned. The lower part consists of an alternation of thin-bedded sandstones and shales, which are carbonaceous at several horizons and contain thin lenses of coal. In the vicinity of the Anchor no. 1 mine, $51 / 2$ miles west of Hunter Canyon, the upper Sego is also characterized by numerous variations both in thickness and in lithology. A bed of coal 4 inches thick in a stratum of carbonaceous shale occurs near the middle. At 
both top and bottom are massive beds of sandstone. Near the mouth of Salt Wash Canyon the lower bed is about 20 feet thick and consists of a cliff-making brown medium-grained thin-bedded sandstone. The upper Sego has the same general character in sec. 10, T. 8 S., R. $102 \mathrm{~W}$., where it is 43 feet thick. Westward from this locality the thickness increases to 75 feet and the sandstone becomes more massive and conspicuous on the face of the cliffs. A medium to coarse grained gray-white sandstone makes the upper 15 feet. The middle 40 feet is especially massive, individual beds attaining a thickness of 10 feet, and contains Halymenites major. The basal portion is thinner-bedded and more shaly and is transitional into the shale of the Anchor Mine tongue below. Ten miles farther west, in West Salt Creek, the upper Sego has the same character, with perhaps a tendency toward greater massiveness.

\section{MOUNT GARFIELD FORMATION}

The beds here named "Mount Garfield formation" occupy the middle portion of the Mesaverde group in the Book Cliffs coal field of Colorado. They form a lithologic unit ranging in thickness from 970 feet in West Salt Creek to 1,070 feet at the Book Cliff mine (pl. 7, A). With the exception of the Anchor coal zone in the Anchor Mine tongue of the Mancos shale and a very thin unnamed coal bed in the upper part of the overlying Hunter Canyon formation, the lower portion of the Mount Garfield formation contains all the coals in the Book Cliffs field of Colorado. From west to east, or basinward, across the field to Plateau Creek, in the vicinity of Grand Mesa, where the beds below the Rollins sandstone member merge into the Mancos shale, the lower member or "coal measures" ranges in thickness from 305 to 666 feet. The variations in thickness appear to occur chiefly between the Palisade and Cameo coal zones.

The upper member of the Mount Garfield formation, locally known as the "barren measures", ranges in thickness from 405 to 665 feet in the Book Cliffs area of Colorado. It thins gradually toward the east as it approaches the Paonia shale member of the Mesaverde formation in the Grand Mesa field.

Throughout the field the Mount Garfield formation is conformable with the enclosing formations. From Plateau Creek westward the base is marked by the top of the Sego sandstone. The upper boundary, being less distinct, is more or less arbitrary and is based on various lithologic differences. The overlying Hunter Canyon formation is differentiated from the Mount Garfield formation chiefly by the difference in character of its sandstones, which are more numerous and also coarser, grayer, and more massive than those below. The carbonaceous shale of the Mount Garfield formation practically 
disappears in the Hunter Canyon formation, which also shows a diminution in the total amount of shale, some of which has a greenish cast. Other differences between these two formations have been mentioned on pages 33 and 34 .

\section{LOWER PART, OR " COAL MEASURES"}

The lower part of the Mount Garfield formation, locally known as the " coal measures", consists of sandstone, shale, sandy shale, carbonaceous shale, and coal. Continental deposits predominate, but their aggregate thickness does not greatly exceed the thickness of the brackish-water strata. Beds of sandstone are most abundant and are rather evenly distributed through the section. Three principal kinds of sandstone are easily recognized- $(a)$ the thick, massive, white littoral Rollins sandstone member and thinner but similar sandstones; $(b)$ massive fluviatile sandstones in beds 2 to 25 feet thick; (c) thin, irregular, in places gnarly sandstones, intercalated with beds of gray shale. The upper portions of some of the thinner, less conspicuous brown littoral sandstone beds are characterized by zones of white quartz sand.

The beds of fluviatile sandstone of the "coal measures" of the Mount Garfield formation are either single massive layers or groups of massive layers, separated by thinner partings of shale and shaly sandstone. Their individual laminae are generally a quarter of an inch or less thick. The beds pinch and swell along the strike and in general are lenticular. Individual beds in the eastern part of the field have a tendency toward greater thickness and massiveness than those in the west.

The outcrop of the "coal measures" is a broken and cliffy slope west of the Book Cliff mine; east of that locality it is a sheer wall. The debris from the softer layers mantles all but the more massive layers, whose upper parts project from the slopes. The soft, friable rocks yield readily to solution and their forms are usually rounded. Pits and cavities are common. The thinner-bedded strata give rise to more broken, jagged forms. Weathered surfaces are commonly yellow, gray-buff, and light brown; locally they are splotched and streaked with limonitic stains. Fresh surfaces are invariably lighter, and their prevailing colors are gray-white, cream, and buff.

The thicker layers of sandstone, whose sand grains average about 0.01 inch in diameter, have a sugary texture. Coarser-grained sands are rare. Quartz is the most common mineral and makes up from 60 to 95 percent of the rock. Of the other constituents, cream-colored weathered feldspars make up 15 to 30 percent, and dark-colored ferromagnesian minerals, 5 to 15 percent. The sandstones thus grade from nearly pure quartzose types toward impure arkosic types. Some beds contain a few small spherical ferruginous concretions, but 
neither these nor clay blebs and pellets are as common as in the massive beds in the upper part of the member.

The thinner-bedded sandstones associated with the shales are hard, dense, and fine-grained, and their weathered surfaces are usually light-reddish brown. They are characterized by ripple and current markings, and their bedding surfaces show thin films of clastic mica and carbonaceous material.

The gray clay shales are a little less abundant than the sandstones with which they are interbedded. They range from thin partings to beds 10 to 30 feet or more thick. Beds of shale containing thin lenses of gray and brown sandstone locally attain a thickness of 100 feet. Much of the sand in these lenses is uncemented. The contacts with overlying and underlying beds of massive sandstone are slightly irregular, and in some places there is evidence of minor channeling. The fresh shale is fissile and consists of many very thin laminae. Its prevailing gray color ranges from light pearl-gray to dull leadgray. The weathered layer at the outcrop is generally 1 or 2 feet thick and has a varied structure. In some beds this weathered layer is flaky, in others rather finely granular, and in a few rudely spheroidal. Some of the thicker shale beds have lenses of dense yellowishgray to brown calcareous concretionary material in the lower part, and some are carbonaceous near the top.

The carbonaceous shales are usually associated with the coal beds of which they are in places an integral part. The Palisade coal zone consists of a unit of carbonaceous shale 30 to 50 feet thick containing at most localities one or more lenses of coal. The Cameo and Carbonera coal zones are also characterized by a rather large proportion of carbonaceous shale. Some of the beds of carbonaceous shale are as much as 45 feet thick. The common colors range from light yellow and reddish brown through the grays to black. The term "chocolate" is in common use to describe the color of much of the shale. Shades of purple, due to the oxidation of the carbonaceous matter, are frequently seen. Most of the shale is more or less fis= sile, an irregular lamination being evident. Occasionally dark-gray or black paper shales are found. The carbonaceous material occurs as mere films separating beds, disseminated bits of carbonized vegetal remains, mineral charcoal, thin lentils of bony and jetlike coal, and, more rarely, small blebs of resin. Sand is a common impurity in the shales, occurring as thin beds of carbonaceous sandstone, as small lenticular channel sandstones, and as free material.

The consideration of the carbonaceous rocks should logically include the description and discussion of the coal beds. However, because of their.importance and value, they are treated in detail in the section on economic geology. 
At the Book Cliff mine the Rollins sandstone is 71 feet thick. The weathered surfaces are light yellow-gray and brown. Below the clinker of the Cameo coal it is locally stained red or purple. Fresh surfaces are grayish white to white. On dip slopes the member is generally eroded into a series of rounded mushroomlike forms because the drainage is controlled by the joint systems of the rock. Some rock tanks among these rounded forms contain fresh water. Bedding is thickest toward the top; but individual laminae an eighth of an inch thick or less were observed. Cross-bedding is present throughout, the scale varying with the thickness of the layers. The rock is coarse-grained and has a sugary texture. The mineralogic composition is estimated to be quartz 80 to 90 percent and dark minerals 10 to 20 percent. At both top and bottom at some localities there are thin bands and lenses of purplish-brown carbonaceous shale containing fragments of carbonized wood and mud pellets. In some places the upper part contains semispherical concretions from 10 to 30 inches in diameter. These weather a rusty brown, but inside they are gray-white like the sandstone. Associated with them at some localities are numerous casts of Halymenites major. No other marine fossils were found.

The Rollins sandstone is of littoral origin and marks the transition from the shallow but open marine environment of the Mancos shale to the estuarine and continental conditions under which the Cameo and Carbonera coals were laid down during the withdrawal of the sea. The eastern portion is slightly younger than the western, for the sea was retiring to the east. The Cameo coal zone lies directly upon the top of the Rollins sandstone or is separated from it by thin bands of carbonaceous shale. Near the Book Cliff mine and in the Hunter mine the bed is cut by "sandstone dikes", which appear to have been injected upward from the Rollins sandstone.

The most conspicuous lithologic unit of the "coal measures" in the eastern part of the Book Cliffs field of Colorado is the massive white cliff-forming Rollins sandstone member. It is similar in character to the Sego sandstone, for which it has been mistaken. East of Platea Creek it is underlain by the Mancos shale, and to the west by coal-bearing rocks belonging to the Mount Garfield formation. The most westerly locality at which this sandstone was found is in the vicinity of the Book Cliff mine. West of the mine it seems to descend stratigraphically, and in sec. 36, T. 9 S., R. 100 W., it is probably represented by a massive white sandstone 65 feet thick, whose top lies 56 feet below the Cameo coal zone. West of this locality its identity is uncertain. The Cameo coal zone persists, however, and just below it at many points or separated from it by 8 to 10 feet of shale are massive purplish gray to white, slightly 50646-34-4 
carbonaceous sandstones of Rollins lithology. These range in thickness from 4 to 10 feet and are not persistent. The name "Rollins" cannot be applied appropriately to any sandstone immediately underlying the Cameo coal zone west of the Book Cliff mine. The maximum extent of typical Rollins from west to east is 85 or 90 miles.

UPPER PART, OR " BARREN MEASURFS"

The lithology of the "barren measures" of the Mount Garfield formation closely resembles that of the "coal measures." The "barren measures" contain very little coal, and the total amount of carbonaceous shale has been reduced from 15 to 6 percent. Though there is somewhat less sandstone, the beds are in general slightly more arkosic and more massive. They also show more decided characteristics of fluviatile origin, especially the cross-bedding. In color, structure, and size of grain (averaging 0.01 inch) the sandstones are similar to those of the "coal measures." The shaly beds in the "barren measures" are like those below, but locally they are much thicker. These deposits are considered to be of continental origin.

RRIATIONS OF MOUNT GARFIELD FORMATION TO BOWIE AND PAONIA SHALE MEMBERS OF GRAND MESA FIEILD

In the Grand Mesa region the basal member of the Mesaverde formation is the Rollins sandstone, except in a small area in the western part of the region, where the upper bench of the Sego sandstone forms the base. Resting upon it are the Bowie and Paonia shale members, and upon the Paonia the undifferentiated Mesaverde, which is equivalent to the Hunter Canyon formation of this report. The Bowie shale as defined by Lee "includes the coal-bearing rocks near the base of the Mesaverde formation, which are distinctly of marine and brackish-water origin."

The Paonia shale member, according to Lee, ${ }^{47}$ " is the coal-bearing portion of the fresh-water division of the Mesaverde formation. Its lower limit can be definitely drawn at the contact with rocks containing marine fossils, but the upper limit is not sharply defined, the rocks differing from the overlying beds, which also contain freshwater fossils, only in the predominance of shale and in the presence of coal." These member names were defined by Lee in the eastern part of the Grand Mesa field. The type locality of the Bowie shale is near the town of Bowie, in sec. 15, T. 13 S., R. 91 W., and the type locality of the Paonia shale is north of the town of Paonia, in the

\footnotetext{
${ }^{47}$ Lee, W. T., Coal fields of Grand Mesa and the West Elk Mountains, Colo.: D.S. Geol. Survey Bull. 510, p. 38, 1912.
} 
northwest quarter of T. 13 S., R. 91 W. Lee was able to trace the Bowie shale from the type locality westward nearly to the Rollins mine, in sec. 35, T. 13 S., R. 96 W., ${ }^{48}$ but does not show it on his geologic map west of sec. 28 , T. 13 S., R. 92 E., probably because of the difficulty of representing so thin a wedge of shale in a nearly vertical outcrop on a small-scale map. From the Rollins mine west and north to Palisade the Paonia shale rests on the top of the Cameo coal zone, which is equivalent to the coal zone at the base of the Bowie shale member east of the Rollins mine. The Bowie shale thus thins toward the west.

The coal-bearing fresh-water beds of the Paonia member on Grand Mesa appear to be the correlative of the non-coal-bearing fluviatile beds of the upper part of the Mount Garfield formation of the Book Cliffs; and the coal-bearing brackish-water shales of the Bowie member are the correlative of the continental deposits (carbonaceous shales) that overlie the Cameo coal zone.

TYPE SECTION

The Mount Garfield formation is thickest in the vicinity of the Book Cliff mine. (See pl. 7, A.) Its character is shown by the section below:

Section of Mount Garfield formation at Book Cliff mine, in the SW1/4 sec. 8, T. 10 S., R. 99 W.

Ft. in.

Non-coal-bearing rocks ("barren measures"): An alternating series of sandstone, sandy shale, and clay shale, with two thin layers of brown carbonaceous shale near the middle and one near the top. The principal beds of sandstone form massive ledges and are five in number. They are about equally spaced, and the lowest is at the base of the unit. In detail they are relatively thin-bedded, the layers being separated by thinner, softer beds or by shaly partings. There is some cross-bedding. Weathered surfaces are reddish brown and have many solution pockets. Fresh surfaces are gray to buff. The grain is medium throughout; the grains are chiefly quartz, but there are some weathered feldspar and some ferromagnesian minerals. There is occasionally a layer of arkosic sand. The shales are predominantly mousegray. They contain more or less sand and carbonaceous material, but only three beds contain much carbonaceous material. Many of the shale beds have a sharply defined base where they rest upon sandstone but grade upward into the overlying sandstone

\&.ee; W. T., op. cit., pp. 50, 79, pl. 1. 
Coal-bearing rocks ("coal measures") :

Ft. in.

56

12

Sandstone, sandy shale, and shale, gray

Shale, carbonaceous, with thin seam of bony coal 4 inches below top

Sandstone, massive, medium-grained, ledge-forming. Weathered surface buff, fresh surface gray. Small spherical ferruginous concretions. Some carbonaceous material. Cross-bedding, in beds 2 to 4 feet thick, separated by thinner layers

Shale, clay, gray

Shale, carbonaceous, with some bony coal__._-_._-

Shale, gray. Limy concretions at base, and large channel sandstone lenses toward top.

Shale, carbonaceous, with bony coal in middle----_---

Sandstone, massive at base, thinner bedded and softer at top, light gray, fine-grained._-_._-_-_-

Shale, carbonaceous _-

Coal, bony

Shale, carbonaceous.--

Sandstone, soft, buff, thin-bedded, medium-grained. Grades up into light-gray sandy shale________ 12

Shale, carbonaceous, brown _._. 1

Coal, bony

Shale, carbonaceous, brown

Coal

Shale, carbonaceous, brown

Coal, bony

Shale, carbonaceous, purplish brown and chocolatebrown. Contains some gray shale and thin Ienses of sandstone

Concretionary layer, calcareous, red-brown on weathered surface, bluish gray on fresh surface. Hard, dense, conchoidal fracture. Rests unevenly on shale surface below

Shale, clay, gray-

Sandstone, massive, reddish brown on weathered surface, lighter on fresh surface; medium-grained. Contact with underlying shale uneven

Shale, carbonaceous, purplish brown. Sandy lenses at top 14

Sandstone, in thin, irregular beds, brown, mediumgrained, cross-bedded on small scale_.

Cameo coal zone:

Coal, bony, with a few thin layers of carbonaceous shale

Shale, carbonaceous, with carbonaceous sandstone at top

Coal, bony, with few thin seams of good coal

Shale, carbonaceous_-_-_-_-_-_-

Coal, bony

$\begin{array}{ll}9 & 5\end{array}$

$\begin{array}{ll}6 & 8\end{array}$

1

Shale, carbonaceous, dark brown to black.--...---

coal, bony

Shale, carbonaceous, purplish gray 
Coal-bearing rocks. ("coal measures") -Continued.

Rollins sandstone member, massive, cliff-forming. Fresh surfaces grayish white to white; weathered surfaces light yellow-gray and brown, locally stained red or purplish by wash from Cameo clinker. Coarse-grained and sugary in texture. Mineralogic composition 80 to 90 percent quartz and 10 to 20 percent dark minerals. Bedding thickest toward top. Cross-bedding present throughout. Locally, at both top and bottom, are thin bands and lenses of purplish-brown carbonaceous shale containing fragments of carbonized wood and mud pellets. Upper part may also contain semispherical concretions of white sandstone 10 to 30 inches in diameter. Associated with them are numerous casts of Halymerites major.

Slope, strata concealed. Probably shale or soft thinbedded sandstone

Sandstone, massive, thin-bedded near base, mediumgrained, cross-bedded.

Shale, gray, interbedded with soft thin-bedded sandstone.

Sandstone, light reddish brown, thin-bedded, flaggy. Plant remains

Shale, gray, carbonaceous. Some thin-bedded brown sandstone near base

Coal, subbituminous

Sandstone, grading up into purplish-gray carbonaceous sandstone

Shale, carbonaceous, purplish gray. Grades into bed above

Sandstone, micaceous. Grades upward into thinbedded purplish-gray sandy carbonaceous shale

Sandstone, upper part cream-colored, lower part buff. Gray-white on fresh surfaces. Thin-bedded, somewhat irregular. Cross-bedding in upper part, which is separated from lower part by false bedding surface. Medium-grained, sugary texture. Solution pits, rounded forms on weathered surface

Sandstone, carbonaceous, dull purplish brown, in thin, irregular, gnarly beds, with some calcareous concretions near base. Thin lenses and stringers of gray cross-bedded sandstone appear near the top, and finally lenses of channel sandstones predominate. Thickness of lenses is half an inch to 3 feet, width in proportion

Sandstone, massive, cliff-making, buff to tan on weathered surfaces, which have a corroded appearance. Medium-grained, arkosic. Evenly bedded, but a cross-bedded layer appears 14 feet above base. Numerous irregular ferruginous concretions at top. Grades into overlying bed 
Coal-bearing rocks ("coal measures")-Continued.
Sandstone, gray on fresh surfaces, in beds ranging from 10 inches to 5 feet in thickness, with shaly parting $5 \pm$ inches thick. Much of shale is carbonaceous. Sandstone laminae may be a quarter of an inch thick or more; shale laminae much thinner. All layers swell and pinch along outerop. Topmost bed consists of intertongued sandstone and shale, locally channeled and filled by sand of overlying bed.

Shale, sandy; grades into bed above.

Shale, carbonaceous, purplish. Contains sandy lenses, which become thicker and more numerous near top.

Palisade coal zone:

Coal, subbituminous

Shale, carbonaceous, chocolate-brown

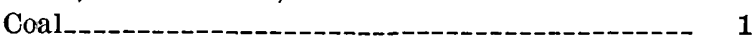

Shale, gray. Limy lens near bottom

Sandstone, gray, weathering $\tan$; thin, irregularly bedded with shale, more massive toward top. Medium-grained, soft, friable, cross-bedded_ 13

Shale, light gray, flaky

Soal, subbituminous, carbonaceous, sandy, yellow-brown, platy. Plant remains. Locally nodular. Becomes less sandy and more carbonaceous toward top

Ft. in. 3

Coal, subbituminous

Shale, carbonaceous, dark brown to black. Contains carbonized vegetal remains, resin. Peppered with many small white grains of quartz sand.

Sego sandstone.

\section{HUNTER CANYON FORMATION}

The Hunter Canyon formation is the highest unit of the Mesaverde group in the Book Cliffs of Colorado. It consists of massive brown-buff and gray sandstone (pl. 8, B) and soft gray shale and ranges in thickness from 375 feet in the western part of the field to 1,400 feet in the eastern part. The general relations of this formation to the underlying Mount Garfield formation and the principal criteria by which the two are distinguished have been mentioned in the discussion of the Mount Garfield. The upper boundary of the Hunter Canyon formation is marked by an evident disconformity, which separates it from an unnamed sandstone of Tertiary (?) age that underlies the Wasatch formation. (See pl. $9, B$.) The maximum erosional relief on the upper surface of the Hunter Canyon formation observable from West Salt Creek to Hunter Canyon is 1,000 feet or more. Details are obscured at most localities, but where exposed a relief of only a few feet is apparent at the base of the channels. A chert-pebble conglomerate or conglomeratic sandstone ranging in thickness from 10 to 40 feet rests upon the eroded surface. 
Sandstone makes up about 60 percent of the Hunter Canyon formation; the proportion in the four detailed sections ranges from 47.5 to 68 percent. The remainder of the formation consists of gray shale, some of which contains thin sandstone layers. Carbonaceous shale makes up about 1 percent. The sandstone beds are conspicuous, more because of their cliff-making habit than because of their abundance. The massive medium to coarse grained beds are 10 to 40 feet thick. At some horizons, however, the groups of sandstone strata are as much as 100 to 300 feet thick. Similar aggregations of shaly strata locally attain a thickness of 100 feet. In places even the thickest sandstone beds split up and finger out abruptly into shale. An unusually good example of this kind of change occurs on the east wall of West Salt Creek Canyon about 4 miles below Atchee.

The bedding of the sandstone is generally regular, and much of it is thinly laminated. False bedding is rather common. The torrential type of cross-bedding appears to be more prevalent in rocks of coarser grain. Some of the strata are channeled upon their upper surfaces. The depressions in such channeled surfaces are commonly shallow and are occupied by a variety of material, including coarse gray sand, sand filmed with carbonaceous matter, and shale or mixtures of grit, sand, and clay. Locally a massive bed shows an erosional unconformity within itself. Many layers contain small spherical ferruginous concretions, few of which exceed 4 inches in diameter. Originally these concretions were probably pyritic, but now those visible at the surface have been altered to limonite. Locally some of the thicker beds contain near their base zones of large, semispherical concretions of dense gray sandstone. The basal portion of many of the beds is characterized by accumulations of mud pellets and lumps. Most of these are flattened parallel to the bedding. The sizes noted range from a quarter of an inch to 2 by 4 inches but those about three-quarters of an inch seem most common.

The predominant color of the Hunter Canyon formation is gray, owing to the abundance of shale and the gray sandstone. The solidity of this color is broken, however, by each individual ledge. Only in Hunter Canyon can a relatively sharp color distinction be made between parts of the formation. There the lower third of the formation is characterized by brownish shale and buff sandstone, whereas the upper part is gray. The entire West Salt Creek section is brownish and buff rather than gray. The East Salt Creek section is predominantly gray, though there is a thick brownish-buff sandstone at the base and a group of gray-brown beds near the middle. There appears to be a lateral gradation of gray into the buffs and browns of the adjacent sections to the east and west. In the Salt Wash section a group of brownish beds well above the prin- 
cipal basal "brown" zone grades laterally into grays. The colors of some of the carbonaceous beds introduce very slight variations which do not affect the predominant shades. Color changes do not seem to be appreciably affected by the mineral composition and grain size of the sandstones.

Weathering is conditioned by the size of grain as well as by the structure and thickness of the sandstone ledges. Rounded forms, including pedestals and turrets, develop on the coarser-grained strata; and more angular and irregular features on the finer-grained rocks. A peculiar result of the differential weathering of some of these sandstones is the sculpturing out on the exposed surfaces of small round "pimply" concretions. Moreover, a variable distribution within the formation of the rocks so affected is evident. Practically every massive bed in the West Salt Creek section is covered with these concretions. In Salt Wash only the basal and middle strata have them. So far as known, none have ever been found upon the sandstones of the Mount Garfield formation. Thus they have been used with the other criteria mentioned as an aid in separating the two formations.

Shale and sandy shale resembling those of the Mount Garfield formation constitute much of the Hunter Canyon formation. The prevailing colors are dull gray and greenish gray. The upper portions of some beds are slightly carbonaceous, which gives them a grayish-purple tone. Black and chocolate-brown carbonaceous shales are rare. Locally, as in the basal part of the East Salt Creek section, there are thin lenses of crimson clay shale in gray-green shale. Most beds contain thin sandy layers which are locally calcareous. Ferruginous concretions occur sparingly. Fossils are few, except for plant remains, and represent a fresh-water environment. Thin beds of coal occur near the top of the Hunter Canyon and Salt Wash sections. It is not possible to correlate the occurrences. The beds are only a few inches thick, but one bed that crops out near the head of Salt Wash Canyon is reported to be about 3 feet thick and to be worked occasionally by local ranchers.

The beds of sandstone and shale of the Hunter Canyon formation are believed to have been deposited in streams and on flood plains and in lakes and swamps tributary to the margin of the retiring late Cretaceous sea. Eastward the rocks of the Hunter Canyon formation pass into sediments of the "barren measures" type, in which shale predominates and carbonaceous shale occurs, though rather sparingly. Still farther east the beds equivalent to the Hunter Canyon formation pass into " coal measures." ${ }^{49}$ Thus in the Book Cliffs rield the rocks of the Hunter Canyon formation are relatively nearer

\footnotetext{
${ }^{29}$ Lee, W. T., Relation of the Cretaceous formations to the Rocl:y Mountains in Colorado and New Mexico: U.S. Geol. Survey Prof. Paper 95, fig. 21, 1916.
} 


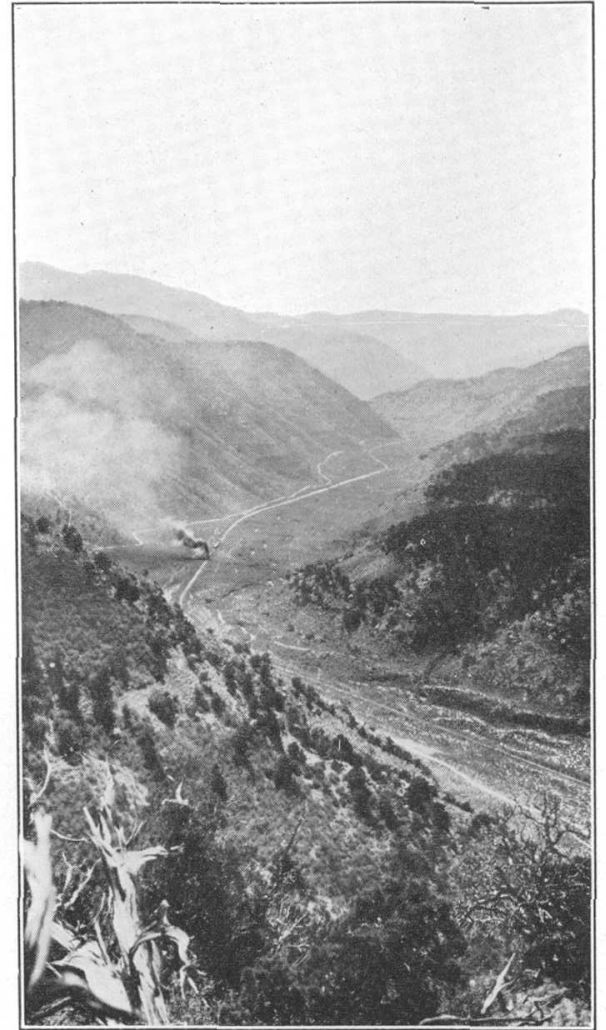

A, VALLEY OF WEST SALT CREEK BETWEEN CARBONERA AND ATCHEE.

Illustrates dissection of Book Plateau, whose summit level appears in profile in the distance. The smoke
is from a locomotive on the Uintah Railway (narrow gage)

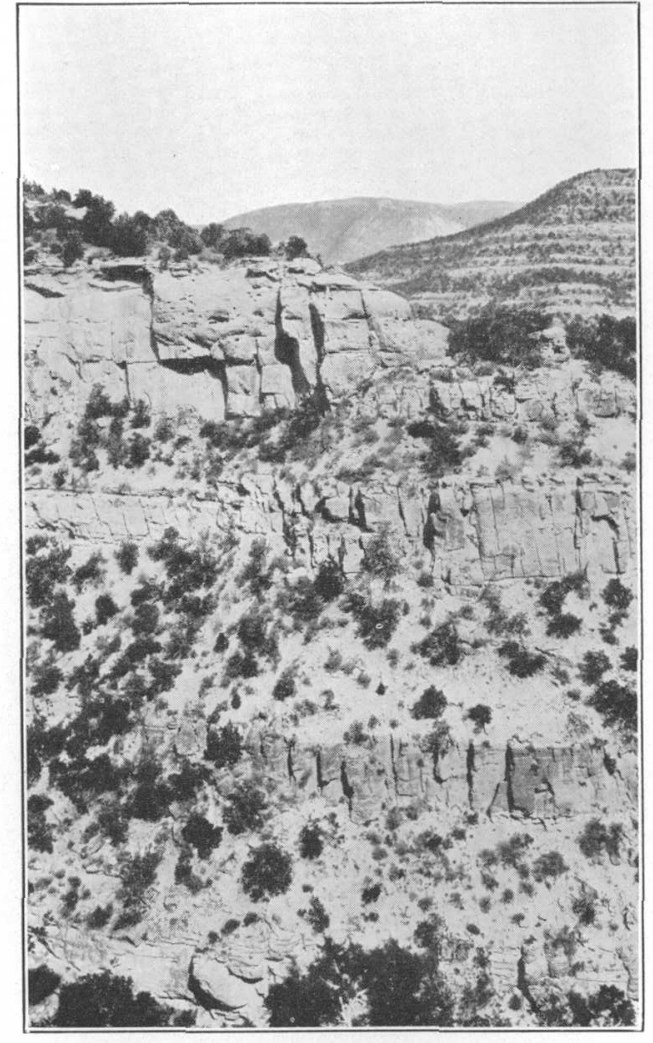

$B$, MASSIVE SANDSTONE OF THE HUNTER CANYON FORMATION IN SEC. 30, T. 7 S., R. $101 \mathrm{~W}$.

A typical distant view of the formation appears to the right. The Roan Cliff's appear in the distance. 


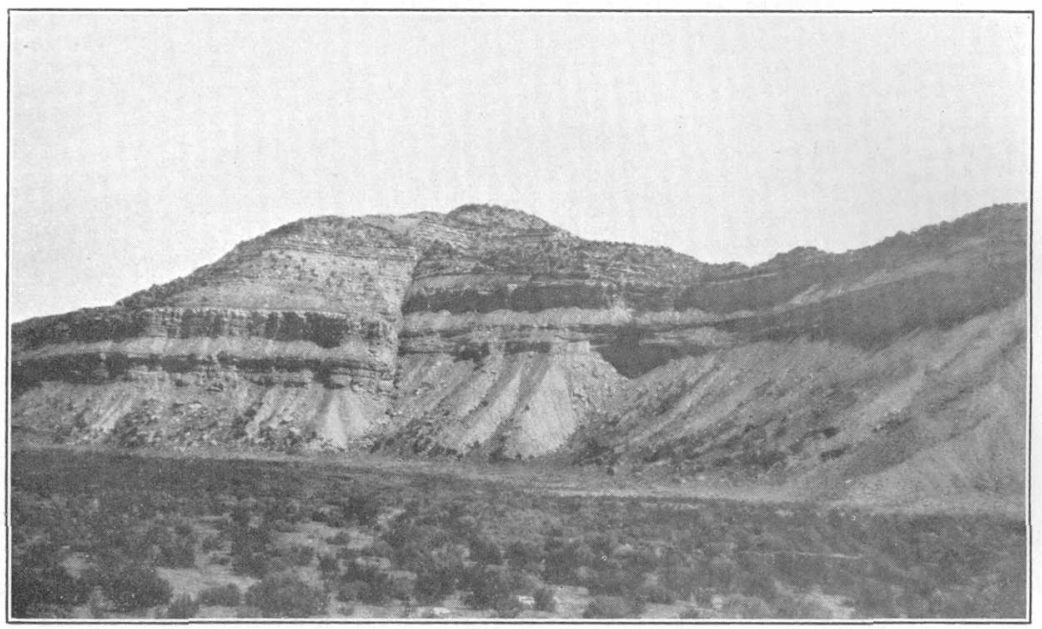

A, NORMAL FAULT, FORMING THE EAST SIDE OF THE GRABEN THROUGH WHICH WEST SALT CREEK FLOWS, IN SW 144 SEC. 26, T. 7 S., R. 104 W.

Downthrow on north is about 150 feet. Threefold nature of Sego sandstone very distinct.

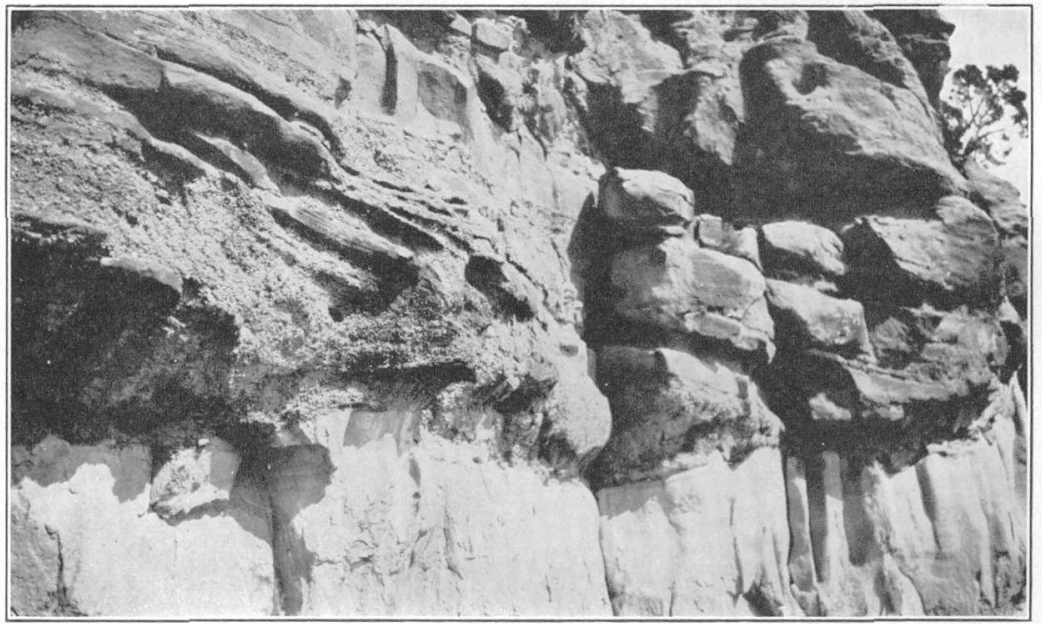

$B$, EROSIONAL UNCONFORMITY AND CONGLOMERATE AT BASE OF TERTIARY (?) SANDSTONE IN N1/2 SEC. 30, T. 7 S., R. 101 W.

The light-colored sandstone is Hunter Canyon; the dark conglomerate is the basal bed of the Tertiary (?) sandstone. 
their source, which is to the west, than the underlying beds. This accounts for the dominance of river-laid deposits in this formation and the less thorough sorting of the sands.

The Hunter Canyon formation is the direct equivalent of the "undifferentiated Mesaverde" of Lee in the Grand Mesa region. To the west in Utah the Hunter Canyon beds are represented by the upper portion of the Farrer member of the Price River formation and by a part or all of the Tuscher formation as defined by Fisher. ${ }^{50}$

\section{Type section of Hunter Canyon formation in Hunter Canyon}

Shale, sandy, soft, mouse-gray, containing thin beds ( 1 to 2 feet) of sandstone, which become thicker toward the base_ 143

Sandstone, massive, medium-grained, gray _..............- $10+$

Shale, sandy, platy, but irregularly bedded, gray, slightly calcareous. Bedding surfaces show current markings. Contains thin lenticular beds of sand, which have same general character

Sandstone, massive, medium-grained, gray-white. Bedding is fairly uniform, but locally it is cut by thin lenses of a more brownish sandstone.

Sandstone (similar to the bed next above) and lead-gray shale containing thinner lenses of sandstone, in alternating beds which vary in thickness from 25 to 40 feet. Just below the highest sandstone bed the shale is dull greenish gray and contains a thin layer of chocolate-brown to black carbonaceous shale and about 4 inches of coal

Sandstone, massive, cliff-forming, medium-grained, gray ("salt and pepper")

Shale, clay, gray

Sandstone, coarse-grained, gray ("salt and pepper")

Shale, clay, gray. Contains thin beds ( 1 to 3 feet) of coarsegrained gray sandstone. About 120 feet above the base there is a massive cliff-forming bed of medium-grained gray ("salt and pepper") sandstone, 20 to 25 feet thick, which lenses out rapidly. Just below the sandstone bed the shale is somewhat carbonaceous, but most of it has the typical gray color

Sandstone in thin beds (maximum 2 feet) interbedded with thin, platy sandy shale

Sandstone, massive. The upper 30 feet is lighter in color and slightly coarser than the lower part, thinly laminated ; cross-bedding well developed. The lower 10 feet is composed of medium-grained gray-buff quartz-feldspar sand with an admixture of ferruginous minerals; characterized by small mud pellets and also contains many small spherical ferruginous concretions, whose maximum diameter is about 2 inches. Near the top there are lenses or channels of varying shapes filled with a coarser, grayer sand

${ }^{50}$ Fisher, D. J., The Book Cliffs coal field in Emery and Grand Counties, Utah : U.S. Geol. Survey Bull. 852 (in preparation). 
Shale, sandy, lead-gray, with a layer of black carbonaceous shale containing fragments of mineral charcoal on the top

Sandstone, thin-bedded, gray. These beds strike N. $45^{\circ} \mathrm{W}$. and $\operatorname{dip} 5^{\circ} \mathrm{NE}$. The beds immediately below them strike N. $75^{\circ} \mathrm{W}$. and $\operatorname{dip} 3^{\circ} \mathrm{N}$. This discordance is probably local and due to large-scale cross-bedding-

Sandstone, massive, gray to buff, composed of an impure quartz-feldspar sand. Some clastic mica over 0.02 inch in diameter. At base average size grain is about 0.01 inch. Bedding is uniform in general, though there is local crossbedding. Basal part contains large irregular fragments of poorly laminated sandy shale.

Shale, sandy, gray, carbonaceous at top. Lenses out rapidly

Sandstone, thin-bedded, and sandy shale, intercalated. The rapid interchange of sandstone and shale is characteristic. Toward the base the beds of sandstone become thinner and more regular.

Sandstone, massive, cliff-forming, light gray, impure, feldspathic. Near middle is thin layer of finely laminated dark-brown carbonaceous sandstone, with thin lenses of normal sandstone. Base is intricately cross-bedded

Shale, thin, platy, lead-gray, carbonaceous. Contains woody remains and thin lenses of sandstone. Passes downward

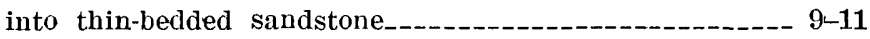

Shale, gray, clay.

Sandstone, coarse-grained, gray. Shows an occasional thin limy layer, cross-bedded, thin-bedded (1 inch) at top_-_--

Shale, sandy, gray, containing many small irregular channels filled with a medium-grained impure feldspathic sand, which is seamed with thin films of carbonaceous material

Sandstone, massive, cliff-forming, coarse-grained, buff. Contains thin layers of gray-green and crimson shale. Weathers into rounded forms, smooth pedestals, and turrets

Shale, sandy, gray to gray-black. Nodular structure. Contains ferruginous concretions

Sandstone, coarse-grained, gray with rusty specks; weathers brownish black. Beds 12 to 16 inches thick, each uniformly cross-bedded, tangential type, dipping north

Shale, grayish to black, containing numerous thin irregular and lenticular layers of medium-grained grayish sandstone. Some are finer-grained, dense, calcareous____-_-_

Sandstone, medium- to coarse-grained, gray, specked with black and brown; weathered surfaces black to brown. Contains thin layers and lenses of greenish-gray sandy shale

Shale, gray to greenish gray, containing thin lenticular gray sandstone which weathers brown. Just above the base 6 to 8 feet of greenish-gray shale is parted by a thin lens of crimson clay shale. 
Sandstone, gray to buff, medium-grained, in massive lenticular beds 30 to 50 feet thick, separated by partings of gray to gray-gleen sandy shale 2 to 6 feet thick. Some of these shale beds contain plant remains. Gross-bedding is infrequent in basal portion but common in upper third, where beds are less massive and are most intricately interbedded with the shale in channels, lenses, and pockets. In many parts isolated lumps of shaly material appear to be enclosed in sandstone. Lateral irregularity of beds very marked. The weathered surfaces of cross-bedded portions are alveolated. The base of the strata of probable postI aramie age is placed at the base of this sandstone 300

\section{TERTIARY (?) SANDSTONE}

A sandstone unit lying unconformably upon the Hunter Canyon formation has been provisionally included in the Wasatch formation on the geologic map.(pl. 1), because the writer believes that it is equivalent to the Ohio Creek conglomerate of the G'rand Mesa region, which was classed by Lee as Tertiary. The field relations of this sandstone unit to the Ohio Creek conglomerate have not been definitely determined, however, nor has the sandstone yielded fossil evidence on which an age assignment can be based.

The unconformity at the base of the sandstone (pl. 9, B) is marked at most localities by a conglomerate or conglomeratic sandstone, which ranges in thickness from 10 to 40 feet. The conglomerate is characterized by an abundance of smooth, well-rounded pebbles of black and gray chert. Pebbles of blue, green, white, and banded chert have been noticed; quartz pebbles are common; jasper and flat pebbles of white limestone are rare. The pebbles range from a quarter of an inch to 2 inches in diameter. A very few cobbles of quartzite as much as 6 inches across are present. Small rounded, flattened pellets of greenish-gray shale (mud) are common. Locally the rock is a mud-pellet conglomerate. The nature of the matrix varies considerably. At some places it is a coarse-grained gray sandstone whose surface locally bears small spherical pimply concretions. Elsewhere it is a mottled yellow and gray fine-grained ferruginous sandstone. Grains of quartz everywhere predominate, but rarely chert grains may constitute 30 percent of the matrix. True conglomerate makes up less than 3.5 percent of the basal unit, and most of this occurs at the base, though in some places conglomeratic sandstone occurs at the top. The basal conglomerate grades upward into coarse gray sandstone which contains thin stringers and lenses of pebbles. One of the striking features of this conglomerate is the great similarity of its pebbles to those of the Dakota (?) conglomerates. 
The sandstone ranges in thickness from 155 to 370 feet and in this region tends to thin eastward. Its lithology differs from place to place. In some sections sandstone is more abundant than shale. The average composition, however, as determined by four detailed sections, is shale 50 percent and sandstone 38 percent. This unit contrasts strikingly with the variegated shale of the overlying Wasatch, in which shale averages 95 percent and sandstone 3 percent. Because of their white and light-gray colors and cliff-forming habit, the sandstone beds of this unit are especially conspicuous. The lightcolored sandstone occurs in massive layers 5 to 10 feet thick. The lowest of these rests directly upon the basal conglomeratic unit. Groups of these beds locally attain a thickness of 60 or 70 feet, but most of the ledges are 15 to 30 feet thick. The sandstone, which weathers to smooth and rounded surfaces, is soft and friable, the grain is medium to coarse, and the mineral composition is rather uniform. Numerous field estimates of composition fall between the following limits: Quartz, 60 to 65 percent; weathered feldspar, 20 to 30 percent; dark minerals, 10 to 15 percent. Lenses and small pellets of greenish-gray clay and thin stringers and pockets of rounded chert pebbles are common. Small pimply concretions similar to those noticed upon the beds of sandstone in the Hunter Canyon formation are plentiful upon the weathered surfaces. Hard, dense, fine-grained sandstone concretions are found in some massive layers. Small ferruginous concretions are conspicuous in some places, and many weathered surfaces are mottled by a light ferruginous stain. False bedding, much of which is of the torrential type, occurs within the individual layers. Some beds of massive sandstone grade laterally into sandy gray clay shale with surprising abruptness.

The sandstones are separated by beds of shale, which range in thickness from 10 to 50 feet. The separation between many of the shale and sandstone beds is not sharp, the transition occurring both vertically and horizontally through an increase in the amount of sand in the shale or by the introduction of a series of thin beds of coarse-grained platy sandstone separated by thin clayey partings. Local sandstone lenses as much as 3 feet in thickness occur in some of the thicker shale beds. Beds of clay shale predominate and have a variety of structure and color. Some of these contain small irregular masses of sand, which appear on the surface as yellow splotches. Other thinner beds have a platy structure, and some contain small amounts of carbonaceous material. Much of the shale weathers down into small hackly fragments a quarter of an inch to half an inch in diameter. The predominant color is gray, though the shade varies considerably, and in nearly all the beds there is a marked greenish 
tone, which was observed but rarely in the Upper Cretaceous shale. This greenish tone persists upward into the Green River formation. Purplish grays and various shades of brown are found in the carbonaceous layers. Thin layers of dull-maroon clay have also been noted.

The mud-ball conglomerates are an interesting though not abundant rock type. They consist of clay pellets and balls ranging in diameter from a quarter of an inch to 1 inch, embedded in a hard, compact matrix of light brown to gray sandy clay. The pellets make up 20 percent or more of the mass. In addition to the clay pellets there are also a few well-rounded pebbles of chert or freshwater limestone; numerous spherical ferruginous concretions colored red and yellow; and casts of unios, which occur in all positions and at all angles with respect to the horizontal.

\section{TERTIARY SYSTEMI}

\section{EOCENE SERIES}

\section{WASATCH FORMATION}

The Wasatch formation consists of variegated clay shales of fluviatile and lacustrine origin, together with a few beds of sandstone. (See pl. 10, B.) The formation is well exposed along the base of the Roan Cliffs, which probably take their name from the coloration of the rocks. The upper half of the formation makes very steep slopes because it is protected by the resistant Green River formation. The lower part lies upon the inner or northern margin of the plateau below the Roan Cliffs. The valleys of the larger washes that head in the cliffs flare open along their courses through these soft rocks. As the shale is particularly susceptible to rain sculpture, many curious pinnacles and fretted turrets have formed where partial protection has been given by sandstone ledges.

The thickness of the formation increases rather regularly eastward from 280 feet at the head of West Salt Creek to 790 feet at the head of Hunter Canyon. The great bulk of the strata consists of sandy and silty clay shales. Some beds are more or less marly. Minor facies are made up of beds with small spherical calcareous concretions, nodular ferruginous concretions, and films of purplish-brown carbonaceous material on some of the bedding surfaces. Sandstone constitutes less than 3 percent of the rocks in this formation, and beds of limestone and limestone conglomerate are rare.

The variegated shale of the Wasatch is separated from the underlying Tertiary (?) sandstone on the basis of lithology, the boundary being placed at the top of the highest massive gray-white cliff-forming sandstone. In all sections but that on East Salt Creek these upper sandstone beds of the underlying unit have conglomeratic phases but 
no thick beds of conglomerate. The variegated shales appear to rest conformably upon the sandstone.

The chief characteristic of the Wasatch formation is the bright. color banding. Belts of shale of dull brick-red and maroon and more rarely lilac and pinkish gray alternate with thoșe showing more somber hues. Shades of red are the most conspicuous and abundant, but the quantity of red shale is exaggerated because of the painting of the underlying rocks by a wash of red clay. Actually the red rocks are subordinate in amount to those with duller hues. Less conspicuous variegations are caused by alternations of yellowbrown and shades of green, and by gray-green and olive-green. Occasional bands of orange color or of black or very light gray occur. In places thick belts of dull gray or greenish shale interrupt the succession of variegated beds. The variegated rocks comprise from 25 to 100 percent of those exposed. The colors appear vivid! from distant viewpoints, but their intensity is strangely lessened to a person standing upon the outcrop.

The sandstone in the variegated shale commonly occurs as thin, slabby masses and as irregular lentils. Massive ledges are rare. The lithology has a considerable range of variation. Some beds are fine-grained and micaceous, with their surfaces covered with pseudomorphs of limonite after pyrite. Thin layers of green sandstone are associated with beds of gray sandstone and locally cap them. The hard brown and reddish-brown beds are more numerous and widely distributed than the softer gray beds.

Layers of fresh-water limestone ranging in thickness from 6 to 18 inches occur. Their weathered surfaces are generally brown. The fresh interior is bluish gray but is speckled by the white fragments of Unio shells and coiled gastropods. The rock is dense, crystalline, and tough and contains an abundance of fossils. A more unusual rock type is the limestone-pebble conglomerate, which has been found only in the West Salt Creek section. It consists of well-rounded pebbles an eighth of an inch to 1 inch in diameter, of dense, structureless light-gray limestone, embedded in a matrix of calcareous sandstone. The occurrence is of interest in that the pebbles may possibly have been derived from the Flagstaff limestone member of the Wasatch formation of the Wasatch Plateau region.

No doubt can exist as to the varicolored shales being part of the Wasatch formation; but the underlying sandstone unit previously described and tentatively mapped with the Wasatch, although here classified as Tertiary (?), may possibly be older than Wasatch. Its stratigraphic position and lithology, except for the included shales, correspond to those of the Ohio Creek conglomerate of Grand' 
Mesa ${ }^{51}$ though direct correlation between the two units has not yet been made. The absence of a thick conglomerate at the base of the variegated shales and the close resemblance of these shales to those of the underlying sandstone influenced the writer's decision to map the sandstone with the Wasatch formation. The possibility also exists that the sandstone may be the equivalent of the Tertiary(?) Tuscher formation of the Book Cliffs of eastern Utah, as defined by Fisher.

The upper boundary of the Wasatch formation is marked by the base of the Green River formation. No stratigraphic break occurs between them, the contact being transitional and indicating a gradual change from a fluvial to a lacustrine environment. Several criteria have been used to make the separation. In the eastern part of the field the boundary is placed where there is an abrupt change from dull brownish-red and maroon shale to very light grays that appear white at a distance. The lighter shales are more thinly laminated, fissile, and less clayey and sandy than the colored shales; however, without the change in color the distinction would often be difficult to make. Slight irregularities in bedding sometimes occur where the boundary has been placed. Locally, the highest unit of the Wasatch is a coarse-grained gray-white sandstone upon which rest thin, papery calcareous shales containing thin beds of ostracode-bearing limestone and somewhat thicker beds of algal limestone. The presence of this calcareous material and the papery shale seems to offer the surest distinction between the two formations, and in the absence of supporting criteria the top of the Wasatch formation may be placed safely below the lowest ledge of organic limestone. Here and there thin lenses of colored fluviatile clay may be found above such a horizon. Owing to the prevalence of sandstone along the contact, the boundary is expressed topographically as a bench in the soft overlying shale. Traced to the west the boundary becomes more uncertain, owing to the interfingering of the two formations.

\section{GREEN RIVER FORMATION}

The Green River formation (see pl. 10, B) occupies the middle position in the Eocene series of western Colorado. On lithologic grounds it has recently been subdivided into four members ${ }^{52}$-in ascending order the Douglas Creek member, Garden Gulch member, Parachute Creek member, and Evacuation Creek member. Of these only the lowest or Douglas Creek member is present in the region. The Parachute Creek member, which contains most of the oil shale

${ }^{61}$ Lee, W. T., Coal fields of Grand Mesa and the West Elk Mountains, Colo.: U.S. Geol. Survey Bull. 510, pp. 48-49, pl. 6, A, 1912. Eldridge, G. H., U.S. Geol. Survey Geol. Atlas, Anthracite-Crested Butte folio (no. 9), 1894.

${ }^{52}$ Bradley, W. H., Origin and microfossils of oil shale in the Green River formation of Colorado and Utah: U.S. Geol. Survey Prof. Paper 168, pp. 9-14, 1931. 
for which the formation is famous, crops out farther to the north and east. The Douglas Creek member forms the upper and most conspicuous portion of the Roan Cliffs. Because of the possibility that beds of oil shale might appear below their usual horizon, the outcrops on the face of the cliffs were examined with considerable care. A layer of oil shale 2 to 3 inches thick and estimated to yield 20 to 25 gallons a ton was discovered 590 feet above the base of the Baxter Pass section, which has a total thickness of 980 feet. A detailed section containing only a few beds of very low grade oil shale was measured by Bradley ${ }^{53}$ at the head of Trail Creek, on the south side of Douglas Creek Pass. A thin layer of oil shale only a quarter of an inch to half an inch thick, estimated to yield about 20 gallons a ton, was found 81 feet above the base of the 624 -foot section which was measured about 11 miles southeast of Douglas Creek Pass in the southeast corner of sec. 10, T. 7 S., R. 102 W. The writer did not examine the Green River formation in detail farther east along the cliffs. However, even in the vicinity of Parachute Creek, north of Grand Valley, Colo., where the Green River formation contains the greatest quantity of oil shale, the Douglas Creek member contains only a few thin beds of oil shale. Therefore the conclusion appears to be justified that the basal member of the Green River formation, though not entirely barren of oil shale, contains a few layers that are either too thin or too low in quality to be of economic value at the present time.

The Douglas Creek member is an assemblage of sandstone, freshwater marlstone, and shale, which reaches a maximum thickness of about 1,200 feet. Many varieties of each rock type are present. The shale makes up 70 to 75 percent of the total. The marlstone makes up 10 to 15 percent and is rather uniformly distributed throughout the section. Sandstone is about twice as abundant in the upper part of the section as in the lower, where it makes up about 10 to 12 percent. An abundance of calcareous material is the dominant characteristic of the member as a whole. Many of the massive, resistant light-colored ledges of marlstone show organic structure. Layers formed from the limy tests of numberless ostracodes make up about half of these rocks, and, roughly, equal amounts of oolitic and algal facies the remainder. A few soft marly beds are also present. The thickness of the beds ranges from a few inches to many feet. Every gradation exists between the ostracode-bearing limestone and the ostracode-bearing shale. The less limy shale beds also contain ostracodes and algal deposits. Clay shale of Wasatch lithology, which locally is varicolored, is rather common. Sandy, platy graygreen shales are perhaps most common. True paper shales are

${ }^{53}$ Bradley, W. H., op. cit., pl. 8. 


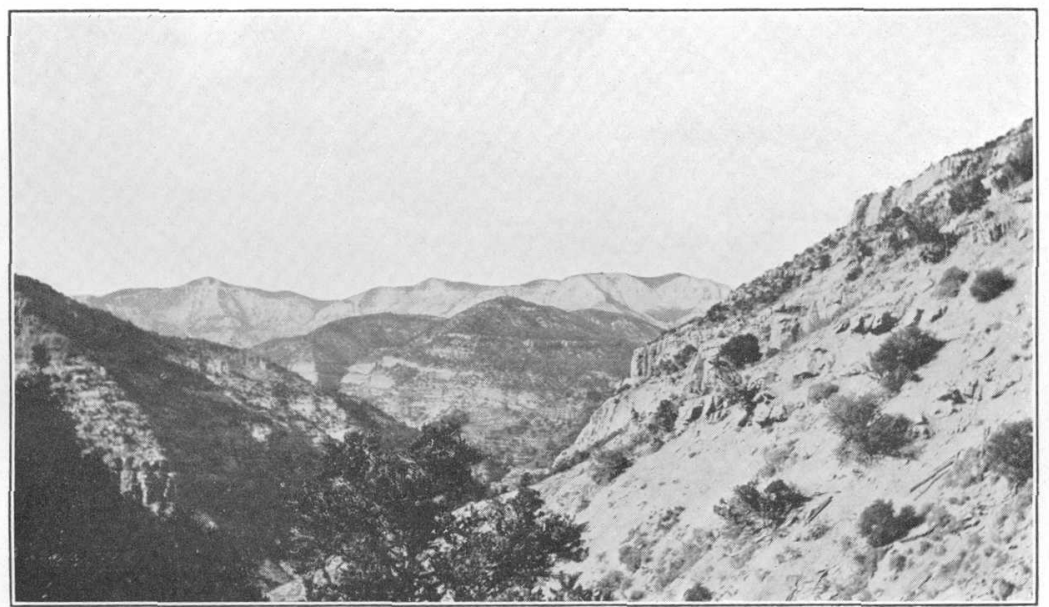

$A$, VIEW NORTHWARD UP HUNTER CANYON FROM POINT 1,200 FEET ABOVE HIDDEN TREASURE MINE.

Illustrates the dissection of the Book Plateau which is here supported upon Hunter Canyon and Wasatch strata. In the distance are the Roan Cliffs (Green River formation).

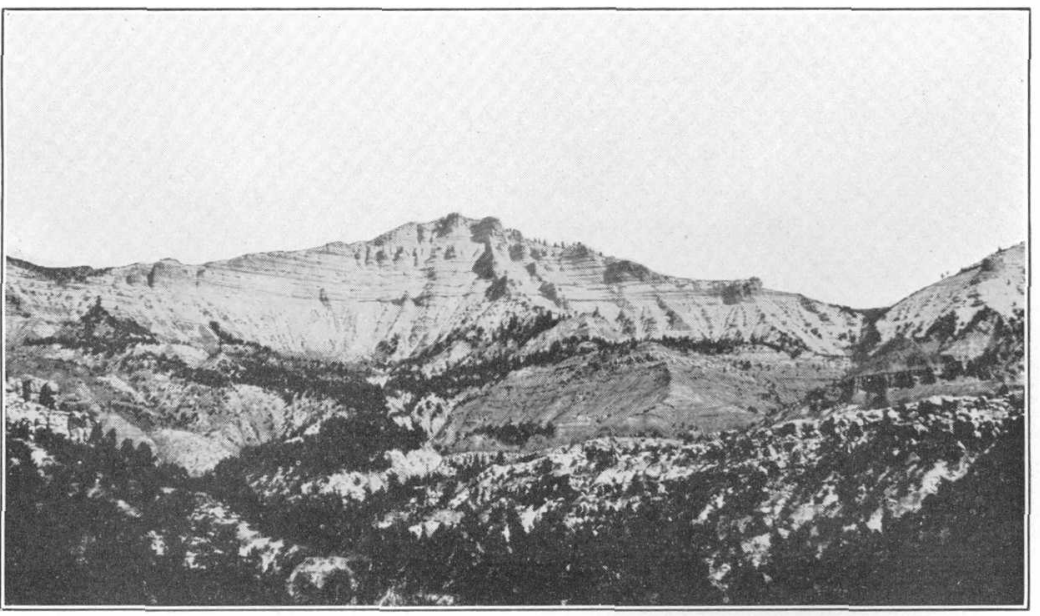

$B$, OUTCROP OF TERTIARY (9) SANDSTONE AND WASATCH AND GREEN RIVER FORMATIONS ON THE ROAN CLIFFS AT HEAD OF HUNTER CANYON.

In the foreground are the Tertiary (?) sandstone, making low broken cliffs; above them is the dark variegated Wasatch shale. The Wasatch-Green River boundary passes through the highest group of spruce on the spur in the mid ground. The appearance of the Green River formation is typical. 
plentiful. They are slightly carbonaceous and are light shades of bluish gray on the weathered surfaces. These, combined with the generally light tones produced by the weathering and leaching of the limy strata, give the member a whitish appearance. The sandstone, is medium-grained and yellow to brown or, if particularly limy, a light gray-buff. The sandstone beds in the upper part of the section usually form massive ledges 10 to 50 feet thick. They grade upward into the overlying shale through zones of thin platy sandstone separated by about equal thicknesses of shale.

\section{QUATERNARY SYSTEM}

\section{TERRACE GRA VEL}

The greater portion of the part of the Mancos shale that floors Grand Valley was at one time or another coated with sheets of gravel and sand. Two general types of deposits may be recognized. One consists of local material, the other of material transported from remote sources by streams. At certain times both kinds were deposited simultaneously over the same area. The gravels found in greatest amounts today are of the first type and were derived from the erosion of the Cretaceous and Tertiary formations in the cliffs. They cap both the high and the low terraces but are almost completely removed from the high terraces. All of the information concerning their nature has been obtained from the deposits on the lower terrace. Their relative thickness at different places suggests that they were probably laid down on the rock-cut bench or pediment at the foot of the cliffs as very low and broad alluvial fans at the mouths of the larger canyons. The major fans did not coalesce for some distance out from the front, owing to the distance between the larger streams. The interfan areas were supplied with minor amounts of material by the smaller streams and by the normal retreat of the cliffs. Owing to its nature most of this material soon crumbled to sand; and where not cemented it was soon scattered by the wind. Contrasted to this is the greater permanence of the algal limestone pebbles from the Green River formation. The distribution of this resistant material, commonly as residual remnants, indicates the former extent of the gravel. Even today, though there are many large angular joint blocks lying on the steep Mancos slopes below the sandstone cliffs, the lack of a well-developed talus mantle is conspicuous, and there is a corresponding absence of coarse detritus along the foot of the cliffs. The surface of these deposits is frequently covered with a fine wind-blown soil. An area where they have been unusually well preserved by cementation lies 3 to 5 miles out from the cliff front in the vicinity of West and East Salt Creeks (pl. 6, $A$ ). 
The other type of deposit is the typical stream gravel composed of hard, resistant igneous and metamorphic rocks now distant from their source. Deposits or remnants of these materials are very rare on the terraces. They are believed to have been laid down by the ancient Colorado River.

The terrace remnants adjacent to the cliffs are indicated on the map, and their relative age is shown by the roman numerals I and II. 'They are very extensive but are more widespread at the foot of the Book Cliffs in Utah, the Wasatch Plateau region, and elsewhere. Their detailed study would certainly yield many interesting and significant geologic and geomorphic data bearing on the late history of the upper Colorado River and its basin, but local detailed studies without the aid of topographic maps and over areas so small as the Book Cliffs region in Colorado, though perhaps of value to some future compilation, would contribute little to these broader problems.

\section{RECENT ALLUVIUM}

Most of the larger streams of the Book Cliffs region contain considerable deposits of recent alluvium. The surface of these deposits is usually flat, and they have been trenched by the present streams to depths of 30 feet or more. The deposits of the narrow upper parts of the stream valleys reflect to a considerable degree the lithology of the immediate tributary slopes. In the smaller tributary valleys and in those which head in local reentrants in the cliff front there is a good deal of loose sand and coarse material. Occasionally a cloudburst torrent has transported considerable masses of very large, angular blocks of sandstone beyond the cliff front for a mile or two. The depasits of the larger stream valleys, such as East Salt Creek, show stratified alluvium, usually of dark color. It consists principally of sand and clay with a scattering of chert pebbles and algal limestone. Fragments of coal and carbonaceous shale are not uncommon. There is a marked absence of coarse material. Away from cliffs on the Mancos shale the amount of shale or mud is greatly increased. When dry the alluvium makes a hard, tough rock that is frequently coated white by efflorescent salts. The alluvium of the Colorado River is much more complex and consists of a great variety of resistant sedimentary rocks such as oil shale and limestone, as well as igneous and metamorphic rocks.

\section{STRUCTURE}

\section{REGIONAL SETTING}

The Book Cliffs coal field is situated on the southern rim of the Uinta Basin and structurally lies within the basin, as the structural rim properly falls along the crest line of the Uncompahgre uplift, some 30 miles to the sonth. (See fig. 4.) The strata rise abruptly 
from the gently northward-dipping floor of the basin into the monoclinal flexure which is the predominant structural feature of the Book Cliffs, especially in the sector between East Salt Creek and Palisade, and a similar but sharper flexure along the north flank of the Uncompahgre uplift.

'The intimate relationship between the steep monoclinal flexures and faults that flank the Uncompahgre and Uinta uplifts is in strict accordance with one of the chief characteristics of "Plateau structure." According to Dutton, ${ }^{54}$

So close is the homology, that we are justified in calling a monoclinal in some of its aspects a modified fault. The only difference for structural purposes is that in the case of a typical fault of the simplest form the shearing is along

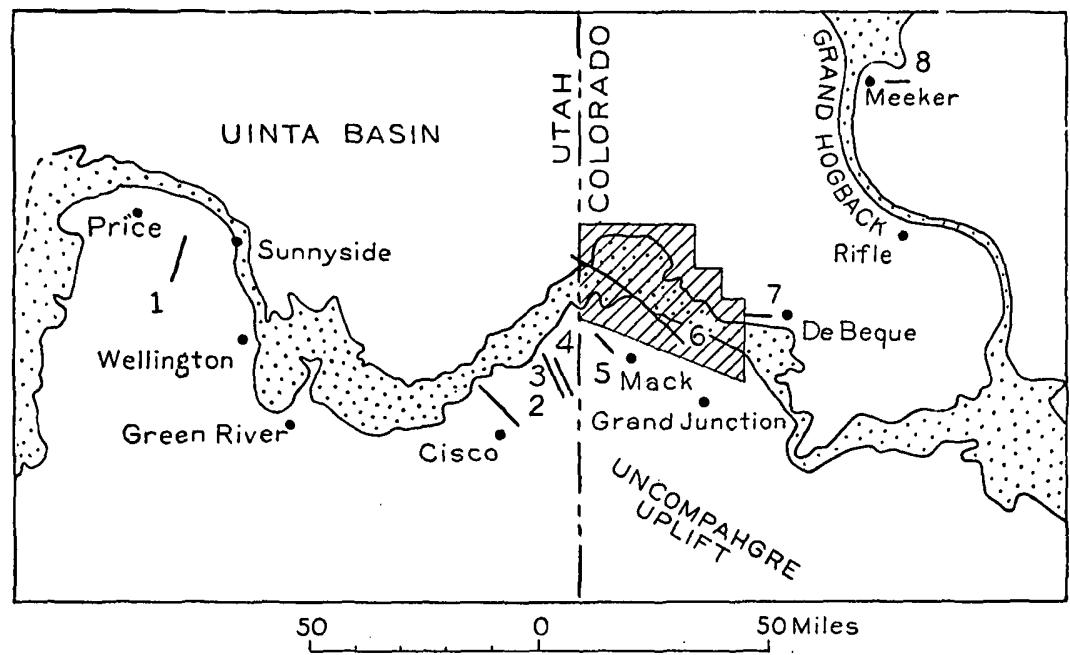

FIGURE 4.- -Sketch map of southern rim of Uinta Basin showing regional structural setting of Book Cliffs coal field. 1, Farnham anticline; 2, Cisco anticline; 3, Harley dome axis ; 4, Bitter Creek axis; 5, High Line dome; 6, Garmesa anticline; 7, DeBeque anticline; 8, Meeker dome.

one plane, while in the monoclinal the shearing lies between two planes. * * All have this in common, that the passage from the uplifted to the lowest thrown side is through a very narrow zone, which has. its width reduced to zero in the case of the single or simple fault. All of the great lines of displacement assume all of these modifications in different parts of their extent.

It is, perhaps, a fair geologic inference to extend this principle to the sharp monoclinal flexure that trends to the northwest along the Book Cliffs of Colorado. Another postulate for which ample precedent exists ${ }^{55}$ is that this flexure passes downward into a deep-seated

${ }_{54}$ Dutton, C. E., Report on the geology of the High Plateaus of Utah, p. 26, U.S. Geog. and Geol. Survey Mtn. Region, 1880.

:5 Thom, W. T., Jr., The relation of deep-seated faults to the surface structural features of central Montana: Am. Assoc. Petroleum Geologists Bull., vol. 7, pp. 1-13, fig. 2, 1923. Robinson, W. I., Folds resulting from vertically acting forces: Jour. Geology, vol. 31, pp. 336-343, 1923. 
fault. If the sedimentary cover could be stripped from the basement complex in the Plateau province the uplifts would probably appear as horsts and the basins as grabens.

In the Book Cliffs region there is a series of asymmetric anticlines and synclines and normal faults in the rocks of the gently inclined marginal platform that lies between the monoclinal flexures on the north flank of the Uncompahgre uplift. (See figs. 4 and 5.) Their distribution is apparently rather irregular. Only the major structural features have been indicated on the sketch, but between these are less pronounced lines of folding or faulting, generally parallel, which, if shown, might indicate greater regularity of spacing. Most of the anticlines lie south of the Book Cliffs, but others intersect the cliff line or lie north of it. The trend of their axes, in passing from west to east around the basin, swings from nearly due north to due east. In the southern part of the Farnham anticline, ${ }^{56}$ Carbon County, Utah, the axis strikes north, but in the northern part it swings eastward until it is N. $13^{\circ} \mathrm{E}$.; it is roughly paralleled by eastwarddipping normal faults. The Cisco anticline, northeast of Ciseo, Utah, trends about $\mathrm{N} .45^{\circ} \mathrm{W}$. It is nearly paralleled by the longer axis of the High Line dome, which strikes N. $50^{\circ}-55^{\circ}$ W. through sec. 8 , T. 8 S., R. 104 W., near Mack, Colo.

The axis of the Garmesa anticline in the Book Cliffs area of Colorado is flexed locally, but its general strike is $\mathrm{N} .50^{\circ}-52^{\circ} \mathrm{W}$. The axis of the DeBeque anticline, ${ }^{57}$ near DeBeque, Colo., is slightly curved, but its general trend is westward. The longer axis of the Meeker dome, 3 miles east of Meeker, Colo., also strikes westward. With the possible exception of the anticline at DeBeque, all the folds are asymmetric, the steep limb being upon the west or south. A somewhat similar distribution of anticlines has been noted about other basins. ${ }^{58}$

\section{STRUCTURAI HISTORY}

The structural history of the region is long and involved. The portion of the history with which this report is concerned began in Cretaceous time with the subsidence of the Colorado geosyncline and the deposition of the Dakota(?) sandstone. This subsidence continued nearly to the end of the Cretaceous period. As the rate of subsidence diminished, slight upwarpings occurred from place to place along the margin, and one of these is believed to be manifested

${ }^{56}$ Clark, F. R., The Farnham anticline, Carbon County, Utah: U.S. Geol. Survey Bull. 711, pp. 1-13, 1920.

57 Woodruff, E. G., Geology and petroleum resources of the DeBeque oil field, Colo.: U.S. Geol. Survey Bull. 531, p. 54, 1913.

${ }_{58}$ Thom, W. T., Jr., op. cit., pl. 1. Reeves, Frank, Geology of the Cat Creek and Devils Basin oil fields and adjacent areas in Montana: U.S. Geol. Survey Bull. 786, pl. 4, 1927. Hewett, D. F., and Lupton, C. T., Anticlines in the southern part of the Big Horn Basin, Wyo.: U.S. Geol. Survey Bull. 656, pl. 1, 1917. 


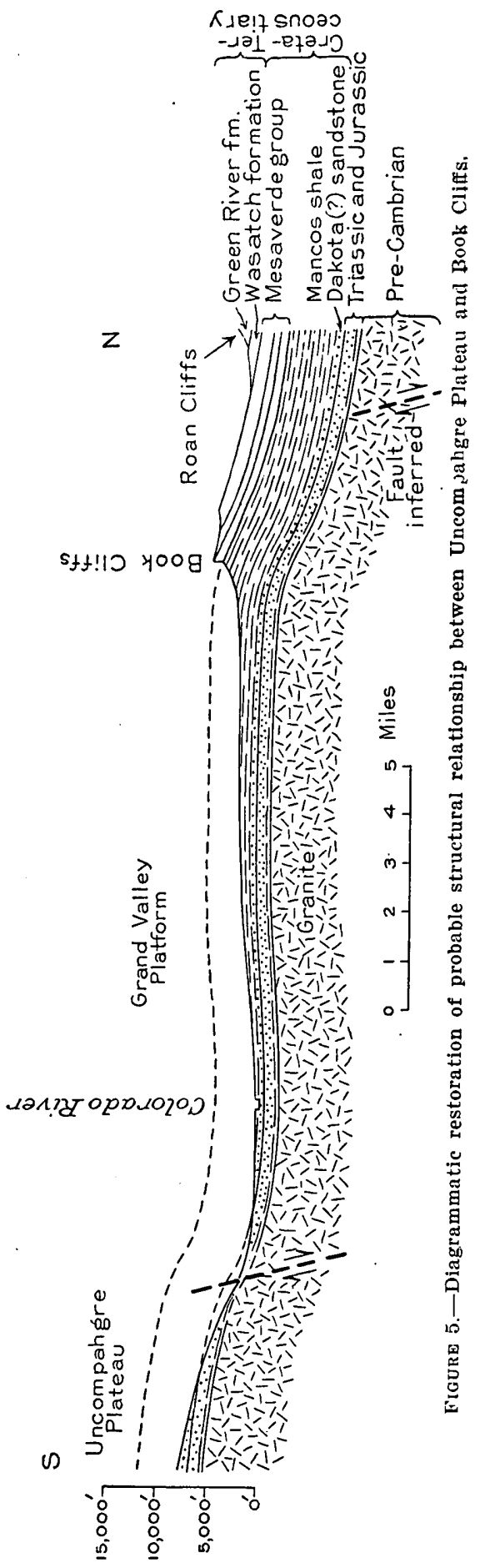


by the presence of the lens of Anchor coal in the Anchor Mine tongue of Mancos shale (p. 36). However, no great break in sedimentation occurred. During late Cretaceous time there was marked uplift and erosion. The Rocky Mountains were formed as a result of this widespread folding. Erosion cut deeply into the Cretaceous rocks. The erosional relief on the Hunter Canyon formation of the Mesaverde group has been mentioned, and locally in adjacent regions the entire thickness of the Mesaverde group was removed ${ }^{50}$ (p. 48). After this erosion the Eocene formations-the Wasatch, Green River, Bridger, and Uinta-were deposited. In post-Uinta time (Miocene?) another period of deformation occurred. The monoclinal folds that flank the Uinta Basin became more sharply defined. Presumably the anticlines along the southern rim were also formed in postUinta time, but inasmuch as they are now expressed only in Cretaceous rocks, exact dating is not possible. They may have been formed during the first period of orogeny. However, there is a general parallelism between the axes of these minor structural features and those developed in the Green River formation, ${ }^{60}$ which suggests that a genetic relationship exists between the two sets of minor folds. Furthermore, as the folding in the Green River formation must have taken place in post-Cretaceous time, it seems reasonable to infer that the minor structural features in the Cretaceous rocks near the rim of the Uinta Basin were also formed in postCretaceous time.

\section{REPRESENTATION OF STRUCTURE}

Though detailed structural mapping was not the mission of the field party, no opportunity to obtain pertinent structural data was overlooked. This information is of much value both practically and scientifically. It enables the geologist and engineer to make more accurate correlations of the coal beds and to predict their probable subsurface extent and their depth below the surface of the ground at any point. It is of much help in planning the layout of new mines or development work, such as the location of rock tunnels and the gradients of entries or slopes, and is of particular value in affording a more thorough understanding of the region and of its relationship to adjacent regions. In this report the geologic map (pl. 1) and the structure-contour map ( $\mathrm{pl} .11$ ) are on separate sheets, and the latter is reduced in scale.

The key horizon selected for structural mapping was the top of the Sego sandstone. Though of great linear extent, the outcrop of

\footnotetext{
${ }^{50}$ Lupton, C. T., The Deep Creek district of the Vernal Coal Field, Uinta County, Utah ! U.S. Geol. Survey Bull. 471, p. 585, 1910.

${ }^{60}$ EIdridge, G. H., The asphalt and bituminous-rock deposits of the United States: U.S. Geol. Survey 22d Ann. Rept., pt. 1, pl. 38, 1901.
} 
this sandstone is very narrow, being heavily covered only a short distance back from the cliff face. Altitudes were taken upon it wherever convenient and were calculated for it elsewhere from altitudes taken on higher or lower beds, reductions being made from stratigraphic data; most of the altitudes were taken on coal beds. Even so, the measurements were too few for the preparation of a detailed structure map with equal accuracy in all parts of the area. In many places the contour lines were spaced by projection of dips; in others they are only "strike lines." ${ }^{11}$ The stratigraphic character of the Sego sandstone should be kept well in mind when interpreting the mäp (pl. 2).

\section{LOCAL STRUCTURE}

For purposes of description the Book Cliffs coal field of Colorado may be divided into a part characterized by monoclinal structure and a part characterized by folds.

\section{MONOCLINES}

A monocline extends from the vicinity of East Salt Creek to Palisade, a distance of about 30 miles. Over this area the dips range from $6^{\circ}$ to $27^{\circ} \mathrm{NE}$., the tendency being to increase toward the east. Locally small areas of steep dip appear, which cause troughs on the slope of the major monocline. The most conspicuous of these is found in the vicinity of the Book Cliff mine, in the southeast corner of sec. 7, T. 10 S., R. $99 \mathrm{~W}$., where the dips range from $23^{\circ}$ to $27^{\circ}$. A few miles to the northwest, in sec. 35, T. 9 S., R. 100 W., there is a similar trough in which the maximum dip observed is $20^{\circ}$. A rather prominent trough exists in secs. $17,18,19$, and 20, T. 8 S., R. $101 \mathrm{~W}$.

The maximum structural relief of the Book Cliffs monocline is 1,300 or 1,400 feet and usually occurs within a distance of half a mile to 2 miles. The transition of the monoclinal flexure to the flatter basinward slope is fairly rapid, the rate of decrease being $3^{\circ}$ or $4^{\circ}$ per mile. Local irregularities of dip occur at the toe of the sharp monoclinal flexure, as in the southwest corner of T. 8 S., R. $100 \mathrm{~W}$. (pl. 1, section E-E'), or the northeast corner of T. 8 S., R. 102 W., where a small dome probably exists.

A large area of relatively flat-lying rocks which occurs between the toe of a major monoclinal flexure and the crest of the next succeeding major monoclinal flexure will be referred to in this report as a structural platform or simply as a platform. Such a feature is actually a huge structural terrace. The crest of the Book Cliffs

Sears, J. D., Geology and ofl and gas prospects of part of Moffat County, Colo., and southern Sweetwater County, Wyo.: U.S. Geol. Survey Bull. 751, p. 298, 1925. 
monocline and the toe of the monoclinal flexure which forms the north flank of the Uncompahgre Plateau are united by an area of nearly horizontal rocks in which the Grand Valley has been carved. This feature is therefore named the Grand Valley platform. As expressed by the rocks of the Mesaverde group, it has been largely destroyed by the erosion. (See fig. 5.) A vestige of the Grand Valley platform apparently caps Mount Garfield (T. 11 S., R. 99 W.), as is suggested by a $5^{\circ}$ dip less than half a mile to the northeast. The presence of a small fault north of Mount Garfield, when considered in connection with the several landslides just east of Mount Garfield, suggests the possibility that this flattening may be due to slump. However, the observable throw of about 40 feet is sufficient to account for only 10 percent of the difference of altitude between the top of the Sego sandstone on the top of the Mount Garfield salient and a higher theoretical altitude obtained by projecting the steep dip of the flexure southwestward over the same point. There is no evidence that the massive beds capping this mountain have slumped down 375 or 400 feet. The flattening is therefore ascribed to the normal decrease in dip from the Book Cliffs monocline to the higher Grand Valley platform.

West of East Salt Creek the Book Cliffs monocline merges into the gently dipping north limb of the Garmesa anticline. The elevated area to the southwest of the adjacent synclinal axis is believed to represent a much larger portion of the Grand Valley platform. The low northward dips locally interrupted by basins, domes of small closure, and faults are regarded as typical of platform structure.

\section{FOLDs}

West of East Salt Creek the Book Cliffs field is characterized by anticlines, low domes, basins, terraces, and troughs, of which the largest and best defined is the Garmesa anticline. Some of these features have a linear arrangement. The breadth of the area affected by this folding is expressed topographically by the greater width of the plateau between the Book and Roan Cliffs. Within the limits of the coal field the upper Mancos is the oldest formation affected by the folding, and the Wasatch the youngest. Along the north flank of the Uncompahgre Plateau the Dakota(?), Morrison, Jurassic, and Triassic formations are involved. Northward the Green River formation and within the Uinta Basin the late Eocene formations have been affected. The economic effects of the folding are (1) the development of a structure apparently favorable to the accumulation of petroleum and natural gas and (2) the effects on the coal beds. In the region affected by the monocline the relatively high dips cause the rapid disappearance of the coals under thick cover. In the folded 

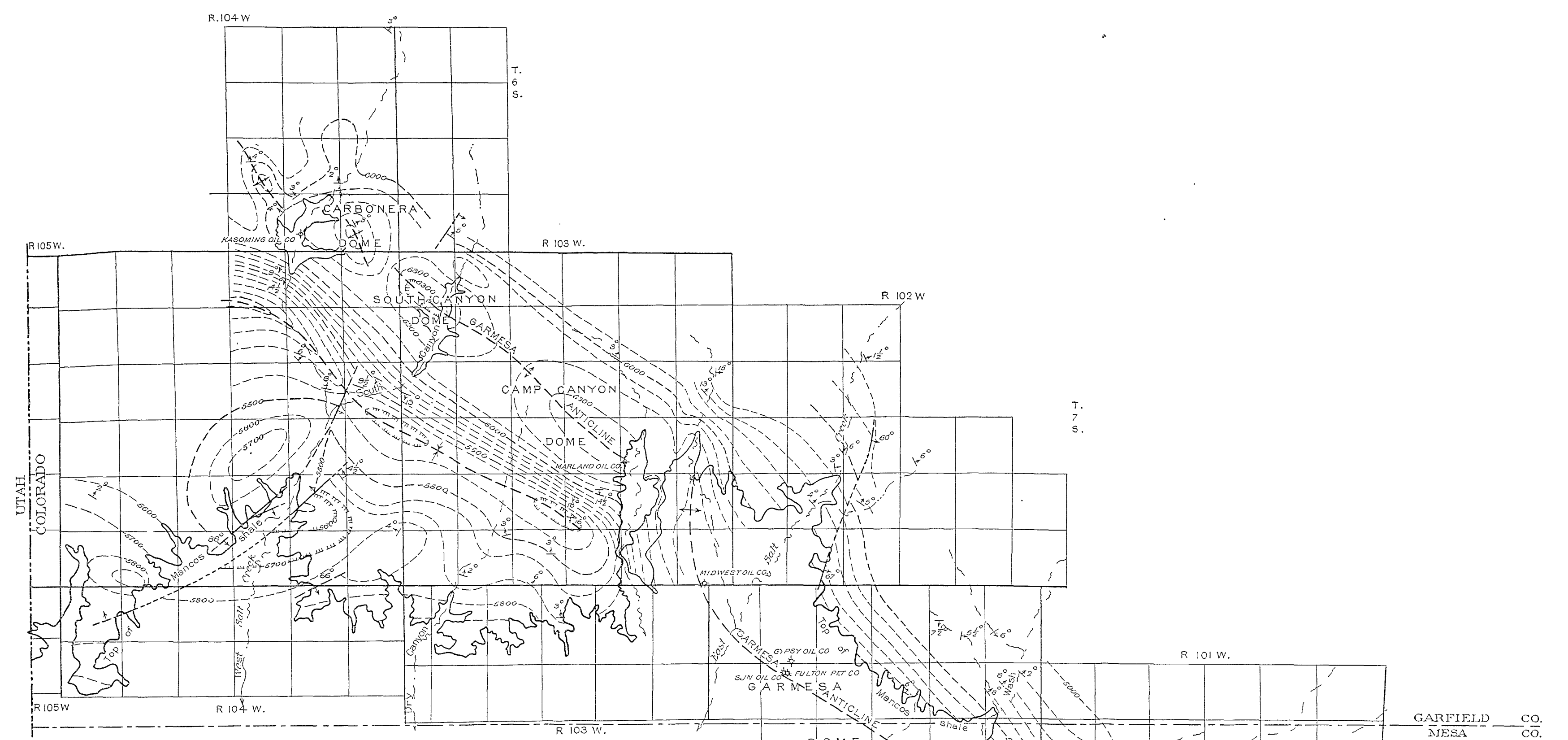

EXPLANATION

(5im

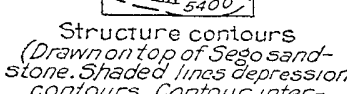

(a)

E-1-

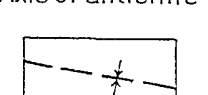

Axiso of sinciline

Foult

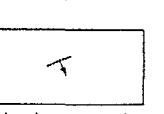

\begin{tabular}{|c|}
\hline * \\
\hline Gas well \\
\hline
\end{tabular}

*

doned gas we the

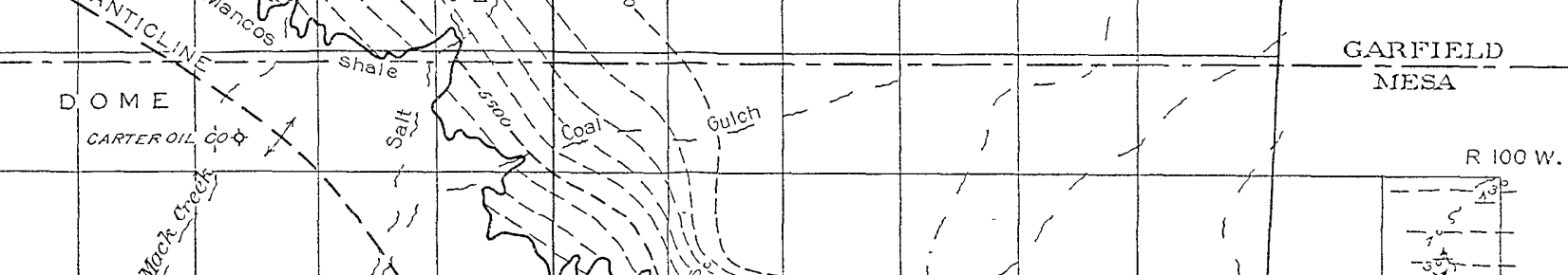
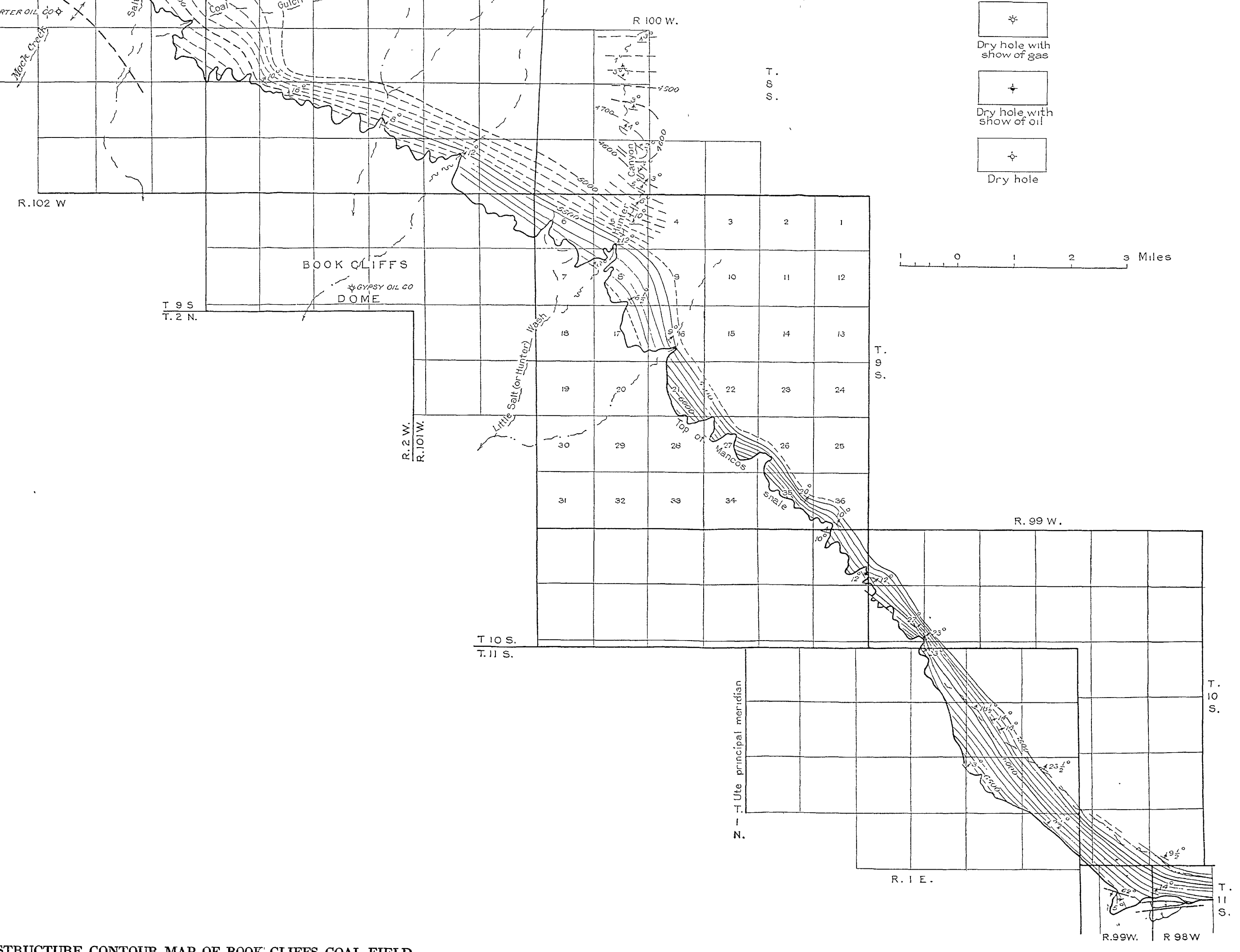
region the coal beds dip under the surface and are then raised to the surface again, greatly increasing the area of outcrop. Of the six deep test wells that had been drilled to date (1927) none discovered oil, and only three gas, which unfortunately is of low heating value. Two of the gas wells have been plugged and abandoned, and the third is shut in at the present time.

\section{GARMESA ANTICLINE}

The Garmesa anticline is an asymmetric, moderately complex fold (pl. 1, sections $\mathbf{A}-\mathbf{A}^{\prime}, \mathrm{B}-\mathrm{B}^{\prime}, \mathrm{C}-\mathrm{C}^{\prime}$ ). The short limb is on the south, where the dip ranges from $9^{\circ}$ to $18^{\circ}$. On the Sego sandstone the usual dip is $13^{\circ}$ to $14^{\circ}$, the lower dip occurring more often in the higher beds. The crest of the fold is rather broad and is characterized by a series of five "highs", or domes, superimposed upon the larger fold, and a corresponding series of saddles or low places between them. From northwest to southeast the highs are named Carbonera dome, South Canyon dome, Camp Canyon dome, Garmesa dome, and Book Cliffs dome. The closure on the highs ranges from 200 to 300 feet. The greatest altitude attained by the top of the Sego sandstone on the anticline is $6,400+$ feet in sec. 36, T. 6 S., R. 104 W.

The north limb of the Garmesa anticline is much flatter and inclines to the northeast at a dip of $2^{\circ}$ to $8^{\circ}$. The structural relief of the anticline as a whole is about 1,400 feet, which corresponds to that of the monocline to the southeast. The axis trends $\mathrm{N} .50^{\circ}-52^{\circ} \mathrm{W}$. but deviates from this course locally. The sharpest bend falls in the southeast corner of T. 7 S., R. 103 W., where a constriction pinches the crest of the fold, causing a saddle that separates two highs. Near the northwest corner of the area mapped (southeast corner T. $6 \mathrm{~S}$., R. $104 \mathrm{~W}$.) the axis splits, a subsidiary axis branching off to the north. The anticline was not examined in detail in the areas not covered by the Sego sandstone. The general trace of the axis is indicated, and it probably extends southeastward into sec. 9, T. 9 S., R. $101 \mathrm{~W}$. Through much of its course it is roughly paralleled on the southwest by a synclinal axis.

The Carbonera dome is in the southeast corner of T. 6 S., R. 104 $\mathrm{W}$., and has a closure of about 200 feet. The 6,200-foot contour on the top of the Sego sandstone is the lowest closing contour and includes an area of about 2 square miles. The Mancos shale appears in an inlier upon the west side of the dome in the canyon of West Salt Creek. The South Canyon dome lies in the northwest corner of T. 7 S., R. 103 W., and the Camp Canyon dome is near the center of the same township. Each has a closure of about 200 feet and an area of abuut 3 square miles. The 6,200-foot contour is the lowest closing contour, but a notable feature of the South Canyon dome is a structural depression on its crest. The top of the Mancos shale 
appears in South Canyon and on the east end of the Camp Canyon dome. The Garmesa dome lies in the large reentrant valley of East Salt Creek in the north half of the northwest quarter of T. 8 S., R. $102 \mathrm{~W}$. It is long and narrow and strongly asymmetric. The lowest closing contour has an altitude of about 6,300 feet and includes an area of about 5 square miles. The surface closure is about 250 feet, and the closure upon the top of the Dakota (?) formation is about 375 feet. The surface formation is Mancos shale, and the details of structure must be worked out upon the concretionary beds in the upper part of that formation. The Book Cliffs dome occurs upon the same major axis 6 miles to the southeast. The face of the Book Cliffs stands 3 miles to the north, and the surface formation is Mancos shale. This dome is smaller than the others and has a closure of less than 100 feet over an area of about 1,000 acres.

\section{HIGH LINE DOME}

The High Line dome is a small elongated structural feature covering an area of about 2 square miles in secs. 23 and 24, T. 8 S., R. $104 \mathrm{~W}$. The axis is essentially parallel to that of the Garmesa anticline. It is cut by a series of transverse normal faults, several of which form small grabens and horsts. The resulting structure is rather complex. A test hole was started in July 1924 on a local "high" on the north end of the dome in the $\mathrm{NE} 1 / 4 \mathrm{NE} 1 / 4 \mathrm{NE} 1 / 4$ sec. 23. After a long period of desultory drilling the top of the $\operatorname{Dakota}($ ?) formation was reached at a depth of 2,800 feet and was found to be dry. The well was deepened to 2,998 feet and has penetrated the top of the Morrison formation. About 200 feet of $61 / 4$-inch pipe was lost at this depth. An effort was made to sidetrack this pipe, and drilling is now indefinitely suspended at the new depth of 2,600 feet.

\section{FAULTS}

Many faults dislocate the strata in the region. All of them are of the normal or gravity type. Two distinct classes may be recognized-faults related to the structural features, and landslides.

Five faults related to general structure were noted. Without exception their strike is normal to that of the major structural axes of the region. This suggests that they were developed by tensional stresses that operated during the period of folding. There appears to have been some lateral movement along them. Their dips range from $60^{\circ}$ to $88^{\circ}$, and the direction of downthrow may be either southeast or northwest. Only three are of more than local importance. Two of these combine to form a fault trough which strikes to the northeast across the southeast quarter of T. 7 S., R. 104 W., and has apparently localized the course of West Salt Creek for a 
short distance through secs. 23, 26, and 27. (See pl. 9, A.) The throw of these two faults increases toward the northeast, where they abruptly die out. The dropped block is tilted to the east (pl. 1,

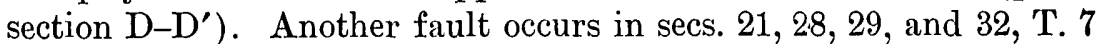
S., R. $102 \mathrm{~W}$. The throw is 235 feet to the east, the greatest recorded, at the north end, and decreases to about 60 feet at the south.end. Near the center of sec. 21 the Cameo coal zone is dropped to the east against the Palisade coal zone, the effect being the apparent and rapid lensing of a thick bed of coal into a thin one. A case of "step faulting " is mentioned on page 141 in connection with the discussion of the Carbonera coal zone in T. 7 S., R. 104 W.

Landslides have occurred at several places along the cliffs, especially in sec. 6 , T. 11 S., R. $98 \mathrm{~W}$. (pl. 1 , section $\mathrm{F}-\mathrm{F}^{\prime}$ ). Two blocks one in front of the other, have dropped there, giving the cliff front a steplike structure. The surface along which the movement occurred is curved, steeper above than below, and the blocks have consequently rotated as they descended. The Sego sandstone in place at the top of the cliff dips $14^{\circ} \mathrm{NE}$. In the back block, which has dropped about 300 feet, the dip of the sandstone has increased to $20^{\circ}$, and in the front block, which has dropped about 200 feet farther, the dip is about $28^{\circ}$. The slump valleys caused by the movement have filled rapidly with detritus from the higher slopes, producing a barren flat on top of each block. (See pl. 2, A.)

A block involving the Cameo and Carbonera coal zones has dropped down the cliff face just west of the Book Cliff mine, in sec. 7, T. 9 S., R. 99 W. The coal is worthless, owing not only to the shattering but also to excessive weathering. A small landslide involving the lower member of the Sego sandstone occurs near the center of the S1/2 sec. 27, T. 7 S., R. 104 W. On the map the trace of the surface of movement appears to branch off from a larger fault. Numerous landslides occur along the Roan Cliffs. They may affect either the Green River or Wasatch formation. They are referred to locally as "white" and "red" slides.

\section{NATURAL GAS}

\section{DEVELOPMENT}

Thick beds of sandstone appear in the outcrops of the Dakota (?), Morrison, and lower formations along the Colorado River. Their occurrence suggests the presence of favorable reservoir beds for oil or gas in the domes on the Garmesa anticline. The Garmesa dome is the largest and most accessible and was therefore selected for the initial tests for the occurrence of oil and gas.

Garmesa dome.-The first hole on the Garmesa dome was drilled by the Carter Oil Co. in the $\mathrm{S} 1 / 2 \mathrm{NE} 1 / 4 \mathrm{SW}^{1} / 4$ sec. 15 , T. 8 S., R. 102 
W., a short distance southwest of the axis of the dome and about 300 feet below the adjacent portions of the crest. The well was started September 12, 1921, and was abandoned in the Mancos shale June 25,1922 , at a depth of 2,790 feet, or about 620 feet above the top of the Dakota (?) formation.

The Sun Oil Co. spudded its no. 1 well on a favorable structural location in the $\mathrm{E} 1 / 2 \mathrm{NE} 1 / 4 \mathrm{NW} 1 / 4$ sec. 8 , 'T. 8 S., R. 102 W., on September 15,1924 , and completed it as a gas well to a depth of 2,872 feet on June 16, 1925. The upper sandstone of the Dakota (?) formation was encountered at 2,820 feet, and a measured flow of $47,000,000$ (?) cubic feet ${ }^{62}$ of gas a day with a reservoir pressure of 825 pounds to the square inch was discovered in a sandstone at a depth of 2,862 to 2,872 feet. The $81 / 4$-inch tools were lost while the casing was being cemented, and as they could not be recovered, the well was abandoned in 1925 . The hole was filled with cement from the bottom to the 2,685-foot level; the remainder was filled with mud fluid, and practically all of the casing pulled. Ten sacks of cement were then dumped into the hole.

About the same time the Midwest Refining Co., spudded its Garmesa no. 1 well in the SE1/4 SE1/4 SW $1 / 4$ sec. 36, T. 7 S., R. 103 W. This hole was well located upon the northwest end of the crest of the Garmesa dome. The top of the Dakota(?) formation was reached at a depth of about 3,040 feet. The sandstone so typical of the upper part of the formation is not present, and the base of the Mancos shale cannot be placed exactly. It is probable, however, that the Mancos does not occur below 3,065 feet. The top of the Morrison was encountered at a depth of 3,260 feet, and drilling was continued to 3,324 feet, where a flow of 10 barrels of salt water an hour was encountered 26 feet below the top of a soft, coarse gray sandstone. A small show of gas was found in the Dakota(?) at 3,165 to 3,182 feet.

On June 27, 1925, the Gypsy Oil Co. spudded its Garmesa no. 1 well in the SW1/4 SW $1 / 4 \mathrm{SE}_{1} / 4$ sec. 5, T. $8 \mathrm{~S}$, R. $102 \mathrm{~W}$. This well is a short distance north of the Sun Oil Co.'s well and is favorably situated upon the dome. The top of the Dakota(?) formation was found at 3,000 feet, and may possibly be a few feet higher. A show of gas not exceeding 250,000 cubic feet a day was found in the Dakota (?) formation at a depth of 3,036 to 3,082 feet, most of the gas coming from the 3,040 -foot level. A volume of $18,000,000$ cubic feet of gas a day was found in a sandstone at 3,132 to 3,151 feet, and the closed-in pressure was 900 pounds to the square inch. This

6a Open flow of 17 pounds to the square inch on a 32 -pound gage from $81 / 4$-inch casing. This measurement was probably taken in a careless manner. Drillers who later worked on the Gypsy Oil Co.'s Garmesa no. 1 well reported that the gas flow from the Sun well did not exceed the first gas flow from the Gypsy Garmesa no. 1, which was $18,000,000$ cubic feet. 
sandstone is lighter in color and coarser in grain than the sandstone of the Dakota (?) formation and is believed to occur at the top of the Morrison formation. The well was shut down at a depth of 3;151 feet, and drilling was not resumed until April 11, 1926. The hole continued in sand, and a small additional amount of gas was found at 3,166 feet. At 3,510 feet another flow of gas measuring about $17,000,000$ cubic feet a day was found in the basal sandstone (Salt Wash member?) of the Morrison. Drilling was continued, and the shales of the Summerville formation were penetrated at 3,547 to 3,587 feet, the Entrada sandstone at 3,507 to 3,700 feet, and the top of the Wingate sandstone at 3,700 feet. A strong flow of gas measuring about $18,000,000$ cubic feet a day was discovered in the Wingate sandstone at 3,755 to 3,765 feet and an additional amount of $22,000,000$ cubic feet a day at 3,765 to 3,769 feet. The well was deepened to 3,871 feet and completed and shut in at that depth on November 24, 1926. The closed-in pressure of the well at this depth was 1,150 pounds to the square inch, and the total volume of gas from beds below the Dakota(?) formation was about $58,000,000$ cubic feet a day. Including the gas from the Dakota(?), the total initial open-flow capacity of the well was about $58,250,000$ cubic feet a day. The gas from the two lower horizons was considered noncommercial because of the high percentage of carbon dioxide, and it was determined to abandon the-well. On October 4, 1927, the well was opened to prepare for abandonment, which was carried out under the direction of petroleum engineers of the Geological Survey. It was found that the mud which had been placed in the well had been absorbed into the formation and that it was necessary to remud the well in order to pull the casing. A severe blowout occurred on November 2, and considerable difficulty was experienced thereafter: The job was finally completed early in December. The failure of this well to discover oil marked the end of the first period of exploration upon the Garmesa dome.

The increased use of carbon dioxide in the refrigeration industry has led to the development of natural gases high in carbon dioxide. The presence of low-grade fuel and carbon dioxide gases in the Garmesa dome attracted the attention of the Fulton Petroleum Corporation, of Seattle, Wash., which believed that it could successfully separate the fuel gases from the carbon dioxide, supply the gas to the nearby towns of Fruita and Grand Junction, and use the carbon dioxide locally for the manufacture of carbon dioxide products. On July 16, 1930, the corporation spudded its Cherrington (Smith) no. 1 well, in the SE $1 / 4 \mathrm{NE}^{1} / 4 \mathrm{NW}^{1} / 4$ sec. 8 , T. 8 S., R. $102 \mathrm{~W}$. This location is about 200 feet east and 95 feet south from the Sun well. On September 9, 1930, the top of the Dakota formation was found at 2,847 feet, and a sandstone yielding daily $18,000,000$ cubic feet of 
gas with a reservoir pressure of 825 pounds to the square inch was discovered at 2,857 to 2,878 feet. On June 6, 1932, the well was tested again by petroleum engineers of the United States Geological Survey and showed an open flow of 10,700,000 cubic feet per 24 hours, with a reservoir pressure of 800 pounds to the square inch. This development work, as well as some experimental work on the beneficiation of the gases, was done by the Fulton Petroleum Corporation with the expectation that it would erect an absorption plant for the removal of carbon dioxide gas on the Colorado River at Fruita. Gas for fuel and power was to be produced from the Dakota(?) formation, and carbon dioxide gases from the Morrison and Wingate through a separate string of pipe. The gas was to be piped from the field to the plant, and after beneficiation the fuel gases were to be distributed to the nearby towns. In the Book Cliffs region of Colorado natural gas must compete with coal of good quality and hydroelectric power.

Book Cliffs dome.-The Gypsy Oil Co. drilled its Marie well no. 1 , in the NE $1 / 4$ SW1/4 SE $1 / 4$ sec. 9, T. 9 S., R. 101 W., on the Book Cliffs dome during the period September 8, 1925, to March 31, 1926. (See pl. 11.) A good show of oil was found at 2,415 feet in the upper 2 feet of a sandstone correlated with the Ferron sandstone member of the Mancos shale, but upon drilling deeper salt water appeared and rose 1,000 feet in the hole. A show of 500,000 cubic feet of gas was found in the basal sandstone of the Dakota(?) formation at 2,583 to 2,609 feet. A flow of 2,000,000 cubic feet of gas a day was found in the Morrison formation at 2,632 feet, and a flow of $5,000,000$ cubic feet at 2,657 feet. After flowing 24 hours the well made 10 barrels of salt water an hour. Drilling continued to a depth of 2,720 feet, where operations ceased for the winter. The following spring drilling was resumed and continued to a depth of 3,785 feet. Water was found in the top of the Entrada sandstone and also in the Wingate sandstone. The Chinle formation was penetrated to a depth of about 65 feet, and if drilling had been continued the preCambrian gneiss would undoubtedly have been encountered within a relatively few feet.

Camp Canyon dome.-The Marland Oil Co. drilled a well on the east end of the Camp Canyon dome in the NW1/4 SW1/4. SW $1 / 4$ sec. 23, T. 7 S., R. 103 W., during the period October 1, 1925, to March 17, 1926. The well starts near the top of the Mancos shale, and the top of the Dakota (?) formation was found at 3,900 feet. A very small amount of water and a slight show of gas were found in a sand at 4,005 to 4,011 feet. Drilling was completed at this depth, and the well abandoned.

Carbonera dome.-A test of the Carbonera dome was started February 2, 1921, by the Kasoming Oil Co. in the $\mathrm{SW} 1 / 4 \mathrm{NE}_{1} / 4 \mathrm{SW}_{1} / 4 \mathrm{sec}$. 
35, T. 6 S., R. 104 W. The hole starts about 100 feet below the top of the Mancos shale. A very small show of wet gas was reported at a depth of 252 feet, and a fair show was reported at 1,210 feet. The lowest depth reported is 1,370 feet, and a total depth of 1,240 feet has also been given. In either case, the test was abandoned about 2,700 feet above the top of the Dakota (?) formation.

Five prospect holes have been drilled at various localities on the Garmeșa anticline to depths not exceeding 550 feet, in compliance with the regulations governing prospecting for oil and gas on public lands.

\section{CORRELATION OF THE GAS SANDS}

Considerable differences of opinion exist as to the stratigraphic position of the first principal gas sand on the Garmesa dome and the location of the boundary between the Dakota (?) and Morrison. The problem is complicated by the disconformable contact of the two formations and the presence in each of greenish shale and lenticular beds of sand.

It is generally assumed by geologists and engineers that the first gas sand found below the base of the Mancos shale in the Gypsy, Sun, and Fulton wells is identical and that it occurs at or near the top of the Morrison formation. There are several objections to the complete acceptance of such an assignment.

The top of the Morrison formation was found in the Gypsy Oil Co.'s Garmesa no. 1 well at a depth of 3,130 feet, and the first large flow of gas was found in sandstone from 3,132 to 3,151 feet. The base of this sand was touched at 3,192 feet, and it is underlain by about 30 feet of green shale. A similar shale 28 feet thick marks the top of the formation at a depth of 3,260 feet in the Midwest well, where it is underlain by a sandstone that appears to be the equivalent of the sandstone below the green shale in the Gypsy well. The Sun well found the top of the Dakota (?) sandstone at a depth of 2,820 feet, and the gas was discovered in a zone about 10 feet thick, 40 feet below the top. The Fulton well found the top of the Dakota (?) at a depth of about 2,847 feet, and the gas was found 10 feet lower in a sandstone about 20 feet thick. In both the Sun and Fuiton wells the gas-yielding sandstones were the first to be encountered below the base of the Mancos shale, and they are identical. Their correlative in the Gypsy well appears to be the 10-foot sandstone, in which a small volume of gas was found at 3,040 feet, just below the coaly zone. If the sandstones of the Sun and Fulton wells are assigned to the top of the Morrison formation, it becomes difficult to explain the absence at these localities of the Dakota(?) sanidstones, which are so noticeable in the Gypsy well. 
In all three wells the first large volumes of gas discovered were around $18,000,000$ cubic feet a day. The closed-in pressure of the Sun and Fulton wells was 825 pounds to the square inch, and that of the Gypsy well was 900 pounds to the square inch. The pressure in all parts of a permeable reservoir rock should be essentially the same; therefore, the variant pressure of the Gypsy well indicates either a closed lens of reservoir sand or a separate sand at greater depth. The difference in character of the gas from the first productive sands in the Gypsy and Fulton wells may be a further indication of different sources.

As the lower gas-bearing beds on the Garmesa dome have been penetrated only by the Gypsy Garmesa no. 1 well, questions as to their correlation from well to well have not been studied. The basal sandstone of the Morrison formation is about 65 feet thick and is probably more persistent than the sandstones of the Dakota (?) ; it thins eastward and is not present in the Gypsy Oil Co.'s Marie well. In this sandstone the gas was first encountered at 3,510 feet, or 15 feet below the top. The producing zone in the Gypsy Garmesa no. 1 well is about 20 feet thick and probably does not exceed 25 feet. The Entrada sandstone, whose total thickness is about 100 feet, has yielded no gas, but there is no reason to believe that it may not contain local accumulations. The Wingate sandstone is probably persistent over the Garmesa dome. Here again local conditions probably control production. The total thickness of the Wingate is about 400 feet, and the gas occurs in a zone 14 feet thick, 55 feet below the top. The entire formation has not been penetrated on this dome, and some gas may. occur at greater depths.

\section{PRODUCTION}

It is apparent that an accurate appraisal of the amount of gas available from the Garmesa dome cannot be made at the present time. The productive area of the Dakota (?) formation is estimated conservatively to be about 520 acres. The upper Morrison, basal Morrison, and Wingate may be productive over the area of surface closure, about 3,125 acres. The results of drilling to October 1930 suggest that gas in commercial quantities from the Dakota(?) formation will be found only on the Garmesa dome. Production of carbon dioxide gases from the Morrison and Wingate. may be expected at depth on the Carbonera, South Canyon, and Camp Canyon domes, but there is no immediate occasion for the development of these sources.

\section{CHARACTER}

Although the presence of considerable volumes of natural gas at four different horizons on the Garmesa dome attracted attention to 
the area, the low fuel value of the gas and the absence of nearby markets lessened the value of the discovery considerably. The character of the gases is shown in the table below:

Analysis of natural gas from Garmesa Dome

\begin{tabular}{|c|c|c|c|c|c|c|}
\hline & 1 & 2 & 3 & 4 & 5 & 6 \\
\hline $\begin{array}{l}\text { Carbon dioxide }\left(\mathrm{CO}_{2}\right) \\
\text { Oxygen }\left(\mathrm{O}_{2}\right) \\
\text { Methane }\left(\mathrm{CH}_{4}\right)^{2} \\
\text { Ethane }\left(\mathrm{C}_{2} \mathrm{H}_{6}\right)^{2} \\
\text { Nitrogen }\left(\mathrm{N}_{2}\right)^{a}-\end{array}$ & $\begin{array}{r}20.0 \\
65.4 \\
4.2 \\
10.4\end{array}$ & $\begin{array}{r}51.5 \\
.0 \\
37.1 \\
3.1 \\
8.3\end{array}$ & $\begin{array}{r}61.05 \\
.27 \\
19.69 \\
4.39 \\
14.60\end{array}$ & $\begin{array}{r}35.62 \\
.07 \\
49.79 \\
2.12 \\
12.40\end{array}$ & $\begin{array}{r}35.8 \\
.2 \\
50.2 \\
3.3 \\
10.5\end{array}$ & $\begin{array}{r}35.7 \\
.20 \\
51.05 \\
3.65 \\
9.35\end{array}$ \\
\hline $\begin{array}{l}\text { Heating value in British thermal units: } b \\
\text { Gross } \\
\text { Net } \\
\text { Available... }\end{array}$ & $\begin{array}{r}100.0 \\
727 \\
662 \\
625\end{array}$ & $\begin{array}{r}100.0 \\
427 \\
389 \\
354\end{array}$ & $\begin{array}{r}100.00 \\
275 \\
251 \\
234\end{array}$ & $\begin{array}{r}100.00 \\
537 \\
489 \\
460\end{array}$ & $\begin{array}{r}100.0 \\
c 579 \\
\end{array}$ & $\begin{array}{r}99.95 \\
\end{array}$ \\
\hline
\end{tabular}

a Includes helium.

- Calculated by the writer.

c Calculated by J. G. Crawford.

1. Gypsy Oil Co., Garmesa no. 1. Upper Morrison; depth, 3,132 to 3,151 feet. Analysis by U.S. Bureau of Mines.

2. Gypsy Oil Co., Garmesa no. 1. Basal Morrison; depth, 3,528 feet. Observed heating value, 405 British thermal units. Speciflc gravity, 1.029. Analysis by Public Service Co. of Colorado. The basal Morrison gas is believed to have been mixed with the upper Morrison gas.

3. Gypsy Oil Co., Garmesa no. 1. Wingate; depth, 3,755 to 3,769 feet. Analysis by U.S. Bureau of Mines. 4. Fulton Petroleum Corporation, Cherrington no. 1. Dakota(?); depth, 2,857 to 2,878 feet. Analysis by U.S. Bureau of Mines, December 1930.

5. Fulton Petroleum Corporation, Cherrington no. 1. Dakota(?); depth, 2,857 to 2,878 feet. Speciflc gravity, calculated, 1.000; observed, 0.975. Analysis by J. G. Crawford, U.S. Ceological Survey, Midwest, Wyo., June 14, 1932 .

6. Áverage of gases 1 and 2.

The striking feature of the gas from the Gypsy well, analyses 1-3, is the progressive increase of carbon dioxide with depth. The gas from the upper Morrison is of the highest rank. Its heating value is comparable to that of artificial gas, which ranges between 600 and 700 British thermal units a cubic foot.

The gas from the Fulton well, as shown by analysis, has a surprisingly high content of carbon dioxide. Three suggestions may be offered to account for this condition: (1) The well may have penetrated an isolated sandstone lens containing gas rich in carbon dioxide, which was not encountered by the other wells. (2) On the assumption that the upper Dakota ('?) sandstones are permeable, the well may have entered a gas zone rich in carbon dioxide which had separated from the fuel gases by gravitative differentiation. The flow from a well in such a sand might agitate the gases and eventually change the composition to their average. As no analysis of the gas from the Sun well is available, the original composition of the Dakota (?) gas is unknown. However, if the Fulton and Gypsy wells are assumed to produce from the same sand, this hypothesis fails, for the gas from the structurally lower Gypsy well contains less carbon dioxide than that from the Fulton well. (3) The average composition of the gases from the upper and lower Morrison sandstones in the Gypsy well, shown in column 6, closely resembles 
the composition of the gas from the Fulton well. The correspondence to the last sample taken from the Fulton well, shown in column 5 , is noteworthy. This similarity suggests a mixture of the Morrison gases in the Fulton well. The Gypsy well penetrated considerable amounts of sand in the Dakota(?) formation from 3,000 to 3,019 feet and 3,036 to 3,082 feet; gas was not reported from the upper sand and only a show from the lower. The hole was open during drilling or in such condition that gas from the Morrison horizons was present outside of the casing. The difference in pressure between the Morrison sandstones and the Dakota (?) sandstone ranged between 75 and about 175 pounds to the square inch (the gas in the Dakota (?) at 3,040 feet being assumed to be under a pressure of 825 pounds). This differential is sufficiently great to cause a flow of the mixed Morrison gases into the Dakota(?) sandstone. The period during which the hole stood open was rather short, and it is doubtful if much gas entered the Dakota(?) sands as long as there was a surface outlet. However, the plugging of this well is not considered ideal, and gas may be escaping now from lower to higher horizons. As nearly 4 years elapsed between the plugging of the Gypsy well and the drilling of the Fulton well, the hypothesis of a mixture of gases seems the most plausible. The Fulton well has exhibited no increase in reservoir pressure over that of the Sun well, as might be expected if repressuring were taking place on a considerable scale. The mixture of the gases by apparently equal volumes, though under different pressures, presents a difficult problem.

\section{COAL DEPOSITS}

\section{GENERAL OCCURRENCE}

The coal-bearing rocks of the Book Cliffs field occur principally in the lower or "coal measures" part of the Mount Garfield formation and in the Anchor Mine tongue of the Mancos shale. The lithology of the "coal measures" is described in detail on pages 41-44 and is shown graphically for various stratigraphic sections in figure 3 ; the lithology of the strata enclosing the Anchor coal zone is described on pages 36-38. Some further details pertaining more to the coals themselves are mentioned here. The average thickness of the coal-bearing rocks as determined from nine detailed sections, is 412 feet. The average lithologic composition of these strata, as determined from the same sections, is coal 5 percent, carbonaceous shale 15 percent, sandstone 44 percent, sandy clays and sandy mudstone 9 percent, mudstone 27 percent. 'The average ratio of coal to noncombustible rock within the coal measures is about 1 to 20 . This figure may be called the "coal ratio" of the coal-bearing beds. It is comparable to the 1 to 22 ratio for some portions of the Fort 
Union formation in eastern Montana and to the 1 to 25 ratio for some parts of the Conemaugh formation in Pennsylvania. A knowledge of this ratio is useful in the early stages of prospecting for coal in any region and for predicting the occurrence of coal in areas of poor exposures. It should be emphasized that the figure gives no indication of the distribution of the coal. In 200 feet of strata the 10 feet of coal which may be expected to exist might occur as a single 10-foot bed, as ten 1-foot beds, or in some other combination. The average ratio of coal to carbonaceous shale is about 1 to 3 and affords an index of the amount of carbonaceous shale that may be associated with a coal seam. At any specific locality these ratios may depart considerably from the average. This local variation in the nine sections used to obtain the average for the Book Cliffs field in Colorado is given in the table below.

Ratio of coal to rock in the coal measures of the Mount Garfield formation, Book Cliffs coal field, Colorado

\begin{tabular}{|c|c|c|c|c|c|}
\hline \multirow[b]{2}{*}{ Location of section } & \multicolumn{2}{|c|}{ Ratio } & \multirow[b]{2}{*}{ Location of section } & \multicolumn{2}{|c|}{ Ratio } \\
\hline & $\begin{array}{c}\text { Coal to } \\
\text { non- } \\
\text { com- } \\
\text { bustible } \\
\text { rock }\end{array}$ & $\begin{array}{c}\text { Coal to } \\
\text { carbon- } \\
\text { aceous } \\
\text { shale }\end{array}$ & & $\begin{array}{c}\text { Coal to } \\
\text { non- } \\
\text { com- } \\
\text { bustible } \\
\text { rock }\end{array}$ & $\begin{array}{l}\text { Coal to } \\
\text { carbon- } \\
\text { aceous } \\
\text { shale }\end{array}$ \\
\hline $\begin{array}{l}\text { Prairie Canyon } \\
\text { West Salt Creek } \\
\text { NE1/4 sec. 4, T. } 8 \text { S., R. } 103 \text { W.- } \\
\text { East Salt Creek. } \\
\text { Sec. 10, T. } 8 \text { S., R. } 102 \text { W. }\end{array}$ & $\begin{array}{l}1: 27 \\
1: 19 \\
1: 21 \\
1: 25 \\
1: 15\end{array}$ & $\begin{array}{l}1: 6 \\
1: 4 \\
1: 4 \\
1: 2 \\
1: 0.02\end{array}$ & $\begin{array}{l}\text { Salt Wash } \\
\text { Hunter Canyon } \\
\text { S1/2 sec. } 36 \text {, T. } 9 \text { S., R. } 100 \mathrm{~W} \\
\text { Book Cliff mine..... }\end{array}$ & $\begin{array}{l}1: 12 \\
1: 20 \\
1: 23 \\
1: 13\end{array}$ & $\begin{array}{l}1: 0.3 \\
1: 3.5 \\
1: 2 \\
1: 4.4\end{array}$ \\
\hline
\end{tabular}

Other comparative data, including tonnage estimates, are given in the table on pages $95-99$.

Because of the fact that the coal deposit occurs usually not in a single, simple, persistent seam but rather as a series of very thin overlapping or interfingering lenticular seams or beds, the term "coal zone" is used in this report. The seams in such a zone may be referred to as a group. Specific reference to a particular bed is made by stating whether it is the upper, middle, or other member of the group. The term "bench" is sometimes used in this connection. As the field was being mapped observations were taken on the most accessible seam, and control on the others was maintained by measuring the intervals to the key bed. The "interval" may be defined as the stratigraphic distance from a point upon one bed, usually the top or base, to a similarly situated point upon an adjacent bed. The term has also been commonly used to designate the stratigraphic distance from the top of one coal seam to the base of the next overlying coal seam. In this report, for the sake of uniformity, the interval used is the distance from the base of one seam to the base 
of the other. Wherever the interval between two seams or groups was so great that their positions could not be accurately represented on the map by a single line, they were mapped separately and given distinguishing names.

\section{NAMES AND INTERVALS OF COAL ZONES}

Four coal zones containing workable seams crop out along the face of the Book Cliffs in Colorado. The highest has been named the "Carbonera coal zone," after the small mining town of that name. Two or three seams are usually present in this zone. About 60 feet below is the Cameo coal zone, named for the mining town of Cameo, in the eastern part of the field. One or two seams are commonly present in this zone; where there are two the interval between them is 30 feet or less. The interval between the base of the Cameo coal zone and the base of the Palisade coal zone, the next lower, ranges from 200 to 450 feet across the field, being greater in the east than in the west. The interval between the base of the Palisade coal zone and the base of the Anchor coal zone, the lowest of the four, ranges from 45 to 60 feet, being less over the middle of the Anchor lens. The earliest mining operations in the field were in one of the lenses of the Palisade zone near the town of Palisade, after which it was named. The Anchor zone was named after the Anchor mines, whose workings penetrate it.

\section{RELATIONS OF COAL ZONES TO SANDSTONES}

Field studies of the coal beds and associated rocks show that the coal zones usually rest upon massive sandstones of the Mesaverde group, which feather out eastward into the Mancos shale. Technically they are known as retreatal littoral sandstones, for they were deposited near the shores of the retiring Upper Cretaceous seas. In Utah the Spring Canyon coal group overlies part of the Spring Canyon tongue of the Star Point sandstone; the Castlegate " $\mathrm{A}$ "coal overlies the Aberdeen sandstone member; the Kenilworth and upper and lower Sunnyside coals are associated with the higher sandstones of the Blackhawk formation. ${ }^{63}$ No coals occur above the massive Castlegate sandstone ${ }^{64}$ west of the Green River. In the area described in this report the Palisade coal zone overlies the Sego sandstone and disappears where the upper member of the Sego blends into the Mancos shale. The Cameo coal zone is similarly related to the Rollins sandstone member in the eastern part of the field. (See pl. 4.)

\footnotetext{
os Clark, F. R., Economic geology of the Castlegate, Wellington, and Sunnyside quadrangles, Carbon County, Utah: U.S. Geol. Survey Bull. 793, pl. 4, 1928.

${ }^{4}$ Fisher, D. J., The Book Cliffs coal fleld in Emery and Grand Counties, Utah; U.S. Geol. Survey Bull. 852 (in preparation).
} 


\section{CONDITIONS OF DEPOSITION}

The lithology and general relations of these littoral sandstones have been studied in great detail by several geologists, including E. B. Spieker, F. R. Clark, D. J. F.isher, and J. B. Reeside, Jr., and the information gathered has thrown much light on the conditions of coal formation.

The land mass from which the sediments were derived lay to the west and north. As the forces of erosion gradually reduced it, fluviatile and other continental deposits were built up along the eastern slope. The regional topographic relief must have been extremely low. In the middle and lower parts of their courses the rivers spread out widely and lost themselves in very broad swampy flood and coastal plains. Much of the land thus covered had only recently appeared from beneath the sea. Low beach and dune barriers lay toward the sea. Occasionally these were breached, and sea water temporarily flooded the fresh-water swamps. The brackishwater environment of the larger estuaries prevailed for a time. Near. the sea wind blew sand from the beaches and dunes landward into the swamps. But the sea was gradually retiring, ever followed by the coastal plain, whose deposits buried the littoral and shallow-water marine sediments. On the land the fluviatile deposits were continually encroaching upon the inner margins of the coastal plain. Geologic conditions were ideal for the development of coal deposits. Climatic conditions were equally favorable. ${ }^{65}$ White says:

Inspection of the fossil floras of the Cretaceous and Tertiary coal swamps points in every case to ample or moderate rainfall and relative mildness of climate. Some of the Cretaceous coals, even including those laid down in central Alaska, were deposited in environments probably no colder than that of Wilmington or Charleston, on the Atlantic coast. In other cases the climate may have been subtropical. Nowhere do we find evidence of semiaridity or of wery severe cold, though frost, possibly somewhat severe, doubtless prevailed in the winters of some of the Tertiary coal fields surrounding the Arctic and occurring even on the Antarctic Continent.

The extensive swampy plains were heavily covered with forests

in which a thin covering of water lay over most of the ground between the trees during at least portions of the year, the conditions being most like the swamps near the coast of the South Atlantic States before draining and in some of the tropical peat-forming swamps, such as those in some of the East Indies. ${ }^{\infty}$

The tangle of stream channels, lakes, and swamps is today represented in the coal zones by lenticular sandstone partings, some of which are of great size, deposits of mudstone, carbonaceous mudstone and shale, and coal. Periodically there were times of rapid and extensive subsidence, when the sea swept landward, deeply burying

a5 White, David, Environmental conditions of deposition of coal: Am. Inst. Min. and Met. Eng., 'Trans., vol. 71, p. 13, 1925.

${ }^{60}$ Idem, pp. 15-16. 
the coal swamps with littoral, estuarine, and off-shore marine deposits. As conditions became more stable after such invasions coal deposition was resumed far to the west of the old shore line, and as the basin gradually filled the swamps moved eastward again over their predecessors. The net result of the crustal movements on coal deposition was to shift the swamps to the east, step by step, and at the same time to a higher position stratigraphically.

The processes by which the vegetal debris in the swamps was converted into coal have been the subject of much recent investigation and have been described in the following papers, which contain many references to the literature of coal:

White, David, The carbonaceous sediments, in Twenhofel, W. H., Treatise on sedimentation, pp. 266-288, Baltimore, 1926. A technical discussion.

Thom, W. T., jr., Petroleum and coal, the keys to the future, pp. 13-33, Princeton, 1929. A short popular treatment of the origin, composition, and classification of coal.

Ashley, G. H., Bituminous coal fields of Pennsylvania, pt. 1, General information on coal: Pennsylvania Topog. and Geol. Survey, 4th ser., Bull. M6, pt. 1, 241 pp., 1928. A popular treatise on coal, with special reference to the Pennsylvania fields.

\section{COAL ZONES}

\section{ANCHOR COAL ZONE}

The Anchor coal is stratigraphically the lowest seam in the Book Cliffs field of Colorado. It occurs at the top of the Anchor Mine tongue of the Mancos shale, and its general relationships have been mentioned in connection with the description of that unit (pp. 36-38 and pl. 4). A detached lens first appears at locality 115 , near the center of sec. 1, T. 9 S., R. 101 W., and is decidedly irregular in both quality and thickness. The main body appears near the Anchor no. 1 mine, in sec. 27 , T. 8 S., R. 101 W., and from this locality the bed can be followed westward along the face of the cliffs for about 9 miles to the vicinity of sec. 10, T. 8 S., R. 102 W., where it disappears. About 10 miles farther west, near the center of the $\mathrm{N} 1 / 2$ sec. 6 , T. 8 S., R. $103 \mathrm{~W}$. (locality 116), there are several thin local lenses at the same horizon.

Natural outcrops are not abundant, and some are inaccessible for study. (See pl. 7, B.) At a few places the coal has burned at the outcrop. Most of the exposures of the bed were obtained in mine workings. Near the Anchor no. 1 mine the coal is about 5 feet thick and clean, and this general condition persists toward the west beyond the Stove Canyon mine, in sec. 12, T. 8 S., R. $102 \mathrm{~W}$. The workable portion of the lens thus has a length of about 9 miles in a straight line, but the actual length of outcrop along the face of the cliffs is about 16 miles. Near the middle of the lens, in the 
vicinity of locality 114a, the quality of the bed is lessened by the great amount of bone in the section.

Over the greater part of the lens the roof is sandstone and clayey sandstone, which usually is separated from the coal by a seam of carbonaceous shale or bone (draw slate) 2 inches to 1 foot thick. The floor of the coal bed is the shale of the Anchor Mine tongue, which is of typical Mancos lithology and grades upward into a zone of carbonaceous shale that may contain thin seams of coal and bony coal not exceeding 1 foot in thickness. The Anchor coal zone does not exceed 9 feet in thickness and usually is much thinner. Timbering is required to support the more extensive openings.

The Anchor coal is of bituminous rank. Fresh surfaces are jetblack, and the luster varies from bright to nearly brilliant in some of the thicker jetlike laminae. These give the coal a banded appearance. Large rectangular flakes of mineral charcoal (mother of coal or fusain) exhibiting a woody structure are common on the bedding surfaces of the groundmass. A golden-brown resin occurs in small stringers and blebs, a few of which stand normal to the bedding surfaces. A good cubical cleavage is present. Some of the cleavage planes are spaced one eighth to one fourth inch apart. However, the coal stands up well, and there is little checking or slaking of the fresh material on exposure.

\section{PALISADE COAL ZONE}

The Palisade coal zone consists of a number of overlapping and isolated lenses of coal in a thick deposit of carbonaceous shale which rests upon the top of the Sego sandstone. The coal beds at this horizon are the most persistent in the Book Cliffs field of Colorado and can be traced westward completely across the Book Cliffs from the vicinity of sec. 25, T. 12 S., R. 97 W., in Colorado, east of the area here described, to Horse Canyon, sec. 4, T. 16 S., R. 14 E., in Utah, ${ }^{67}$ an air-line distance of about 75 miles. The actual length of the outcrop along the face of the cliffs is, of course, very much greater. In Colorado the length of outcrop of the part of the zone containing workable beds of coal is about 75 miles. Outcrops are generally good but are better in the eastern part of the Book Cliffs field of Colorado than farther west in the State, where there is more burning. Usually they are difficult of access.

The thickness of the zone varies considerably from place to place and ranges from 10 to 70 feet. The stratigraphic interval from the top of the Sego sandstone to the base of the underlying Anchor coal is about 50 feet; the interval to the base of the overlying Cameo seam ranges from 200 to 450 feet. At least seven well-defined lenses

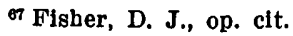


of coal have been recognized in the Palisade coal zone, but no more than three are represented in a single vertical section $(100, \mathrm{pl} .17)$. In addition there are innumerable thin, nonpersistent lentils which are not discussed here.

West of the mouth of Hunter Canyon, sec. 5, T. 9 S., R. 100 W., where the Hidden Treasure mine is located in the upper bench of the Palisade zone, this zone contains no easily accessible seam of good quality coal in Colorado. East of Hunter Canyon there are four major lenses in this zone-two near the top and two at the base. As there is some overlap, the beds are fairly thick over the entire distance from Hunter Canyon to the Midwest mine, in sec. 13, T. 11 S., R. 98 W., east of the Book Cliffs area. Smaller detached lenses serve as connecting links. The larger lenses can be followed for 5 to 12 miles along the face of the cliffs; and their thickness ranges from 1 to 4 feet. West of Hunter Canyon three lenses containing beds of coal more than 2 feet thick have been recognized. The thickest and most extensive is in T. 7 S., R. 103 W., and the northern part of T. 8 S., R. 103 W. Two local lenses occur in and near sec. 28, T. 7 S., R. $104 \mathrm{~W}$.

The carbonaceous shale, sandstone, and mudstone which enclose and separate the seams exhibit as much variation in thickness and character as the coal. The relationships of these rock types are so intricate that a detailed description of the zone as a whole cannot be given. The principal cause of this complexity is depositional, but some of the variations are probably due to differential compaction of the silt and carbonaceous matter over the less compactible bodies of sand. The nature of that portion of the zone between Salt Wash and the Stokes mine is indicated diagrammatically in plate $5, C$. Although the relations pictured may appear exaggerated, plotting on so small a scale has necessitated much simplification and generalization. However, some complications have been introduced by the great disparity between the horizontal and vertical scales, by projecting some coal sections to the line of the section, and by assuming that the top of the Sego sandstone is horizontal.

The lenses and lentils of coal in the Palisade zone are of bituminous rank but of variable grade. The luster of fresh coal ranges from dull to subbrilliant, and the variation of luster from layer to layer brings out the laminated structure. The bony material is usually a lusterless black, which may weather bluish gray. Mineral charcoal is common on the bedding surfaces and is an important constituent of the dull coal or groundmass that encloses the small brilliant lenses. Fossil resin is generally not abundant. The fresh coal is fairly hard but brittle; however, it handles and keeps very well. Two cleavages are distinct, and there is a tendency to show a third. The fracture in the third direction is subconchoidal. The partings of the carbon- 


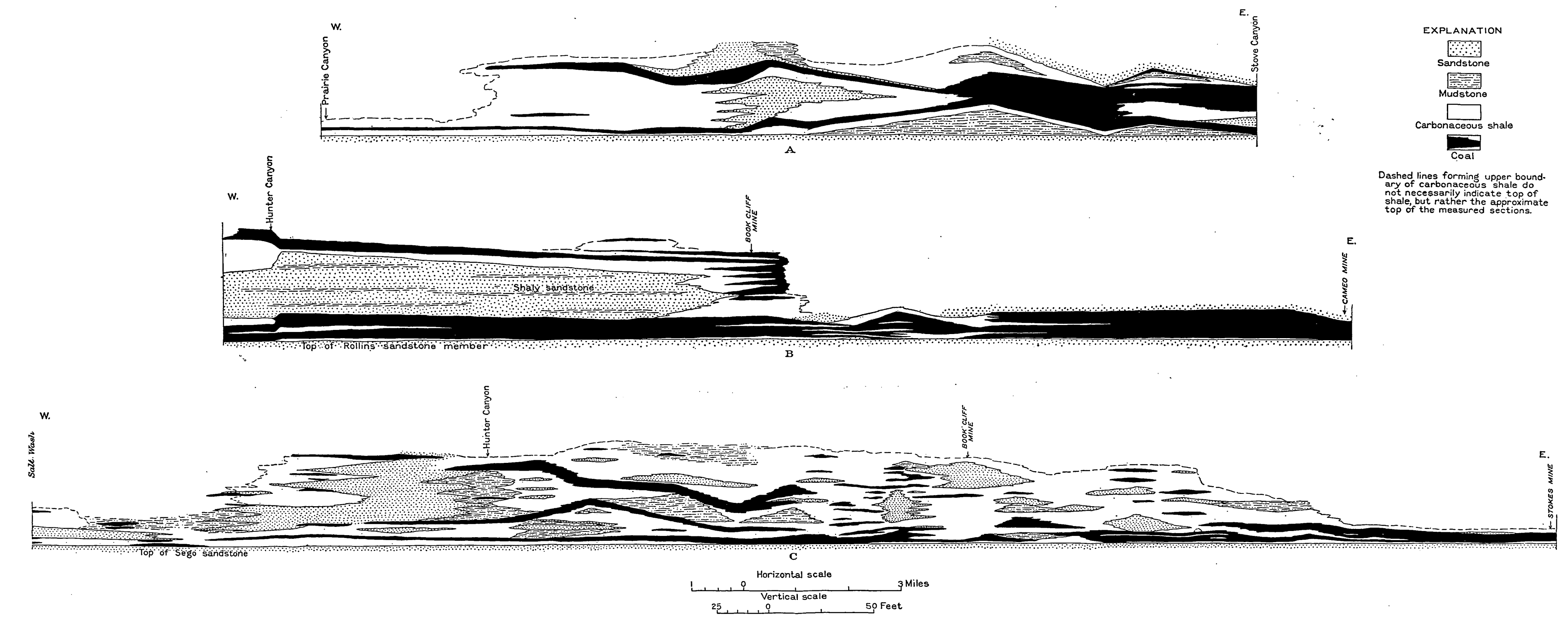


aceous shale and bone are usually very conspicuous on the outcrops, because of the greater resistance they offer to weathering and the difference in color. In some places they are so numerous as to destroy the worth of the bed. Most of the seams in the Palisade zone are characterized by local irregularities in thickness. These may be due to rolling of the floor, to "horsebacks", or to "pinching ", but more probably to nondeposition of the coal. Partings and changes in composition may develop within short distances. If a mine opening is contemplated at any point on a seam, the outcrops for some distance on both sides should be examined in great detail, by trenching if necessary, in order to select the most favorable site. Numerous mines and prospects in the Palisade zone have had to be abandoned because of adverse conditions encountered after entering the seam. So far as known, the Palisade zone is not affected by sandstone "dikes", such as are characteristic of the basal part of the Cameo zone at some localities.

\section{CAMEO COAL ZONE}

The Cameo zone is notable for the thickness of its seams and its great extent. It is the most productive coal zone in the Book Cliffs field of Colorado. Nearly twice as much coal has been mined from it as from all other beds combined. During 1927 four mines in the Cameo zone produced over 76,000 short tons. Most of the coal has come from the Cameo mine, near Cameo, on the Denver \& Rio Grande Western Railroad. The output of this mine exceeds the total output of all the other mines in the field.

The interval to the base of the underlying Palisade coal zone ranges from 200 feet in the western part of the field to 450 feet at the east end. The interval from the base of the Cameo zone to the base of the overlying Carbonera coal zone is about 60 feet. The Cameo zone can be traced throughout the length of the field. In the eastern part it immediately overlies the massive white Rollins sandstone. West of the Book Cliff mine the Rollins sandstone seems to descend stratigraphically, and west of sec. 36, T. 9 S., R. 100.W., where its identity as typical Rollins is lost, several thinner sandstones of similar lithology occupy its horizon. The uppermost of these thin sandstones is usually separated from the base of the Cameo coal by carbonaceous shale and mudstone. In the Book Cliffs of Utah the Chesterfield coal zone is probably the equivalent of the Cameo. ${ }^{68}$

Because of its stratigraphic position the Cameo zone occupies a relatively high position in the cliffs; and where it is underlain by the Rollins sandstone it is made even more inaccessible by the sheer cliff of that sandstone. Because of extensive burning the outcrops are not so numerous as those of the Palisade zone, nor are there as many

\footnotetext{
ss Fisher, D. J., op. cit.
} 
artificial openings. A few outcrops, however, such as that in McLane Canyon (pl. 14, B) and those in sec. 13, T. 1 N., R. 1 E., are excellent. The lack of outcrops is particularly noticeable between Hunter Canyon and Stove Canyon. Detailed examination of the bed was therefore possible only on each side of this area-that is, between the Cameo mine and Hunter Canyon on the east and between Stove Canyon and Prairie Canyon on the west. (See pl. 12, A, B.) In the eastern part of the zone the coal is thick and immediately overlies the Rollins sandstone. The thickness increases rapidly westward from the vicinity of the Book Cliff mine. Much of the coal is bony, with rapid change between clean and bony coal. An upper bench of - clean coal separated from the lower bony seam by a thick parting of sandstone and shaly sandstone characterizes the portion of the zone between Hunter Canyon and the Book Cliff mine. The west end of the zone exhibits great variations in thickness of the coal. The thick lens between East Salt Creek and Stove Canyon contains some of the best coal in the zone, but it interfingers with carbonaceous shale to the east and west and gradually thins. Westward the coal thins, but the carbonaceous shale persists with approximately its same thickness as far as the State line, where it also thins.

The Cameo coal is of bituminous rank and of variable grade. On the few good natural outcrops the weathered surfaces are dull brownish black, with an occasional layer of higher luster. Partings and impurities are conspicuous because of the bluish oxidation color of the carbonaceous material. Fresh coal shows a brighter luster, and its laminated structure is clearly evident. The thin seams and lentils of jetlike coal range in thickness from one sixty-fourth to half an inch and may persist for several feet. Mineral charcoal, which shows upon bedding planes, is a conspicuous constituent of the dull coaly material. Fossil resin is sparingly distributed through the coal. The clean coal usually exhibits two good cleavages, which give it a blocky structure, and in some localities there is a suggestion of cubic cleavage.

One of the chief characteristics of the Cameo coal is the large amount of bone-coal whose ash content is 50 percent or more. ${ }^{69}$ Practically every section contains some bone, and locally it predominates. It is commonly associated with carbonaceous shale. Bone is much more difficult to handle than carbonaceous shale, as it does not tend to break clean when the coal is mined. The lower seams of the Cameo zone are the dirtiest, and at many places the good coal is separated from the impure by a shale parting. Carbonaceous shale is the most abundant and conspicuous impurity, but locally

${ }^{69}$ Ashley, G. H., Bituminous coal fields of Pennsylvania, pt. 1, General information on coal : Pennsylvania Topog. and Geol. Survey, 4th ser., Bull. M6, pt. 1, p. 63, 1928. 
the coal just above the Rollins sandstone is "salted" with grains of wind-blown quartz sand.

Sandstone dikes are also characteristic of the Cameo zone. They are present at the.Hunter mine, and the one at the Book Cliff mine is of especial interest because it has been dislocated. It appears in cross section upon the outcrop (locality 53a), about 800 feet north of the portal of the Book Cliff mine. The dike has been described by Lakes ${ }^{70}$ who states that it was followed in the coal bed for about 200 feet. The base of the upper part of the dike is 20 feet above and 30 feet west of the base of the lower part. The upper part strikes N. $5^{\circ} \mathrm{E}$. and dips $80^{\circ} \mathrm{W}$., and the lower part strikes N. $20^{\circ} \mathrm{E}$. and dips $52^{\circ} \mathrm{W}$. Small dragged blocks of sandstone suggest that the upper part has moved westward with respect to the lower. The upper part is wedge-shaped, measuring 12 feet in height and 15 inches in width at the base, which has been cut off squarely; its walls are more or less irregular. Around the dragged blocks the coal is contorted and seems to feather into sandstone. The lower part is 20 feet high, 11 inches wide at the severed top, and 2 feet wide at the base; it is much more regular than the upper part, having suffered less movement. However, coal occurs along several joints parallel to the base.

The lithology of each portion of the dike is the same. It is composed of dense gray-white sandstone containing small pellets of mudstone and fragments of carbonaceous material. Some lenses of calcite are present, which carry small inclusions of sandstone. This lithology is identical with that of the underlying Rollins sandstone, which is regarded as the source of the material.

Sandstone dikes injected from below upward are considered by Daly ${ }^{71}$ to be an effect of earthquake shocks. The earthquake that gave rise to the dikes in the Cameo zone probably occurred in late Cretaceous time, perhaps not long after the deposition of the coal and while the underlying beds were still flat-lying and saturated with water. The dislocation took place at a much later period, when the strata were being flexed into the Book Cliffs monocline. The very incompetent coal beds were compressed by the powerful stresses acting within the limb of the fold and flowed laterally, thus snapping off the brittle dike. It is interesting to note that were it not for the dislocation of such structural features it would be impossible to detect movement within the coal bed. The heat and pressure generated by such movements, however slight, materially aid in the alteration of coal from low to high rank.

${ }^{70}$ Lakes, Arthur, The Book Cliff coal mines : Mines and Minerals, vol. 24, pp. 289-291, 1904 .

${ }^{71}$ Daly, R. A., Our mobile earth, pp. 38, 39, New York, 1926. Gives an explanation of the origin of sandstone dikes in nontechnical terms. 


\section{CARBONERA COAL ZONE}

The coals in the Carbonera zone are the highest in the Book Cliffs field. Two seams are usually present and at some places three. The base of the lower seam lies about 60 feet above the base of the Cameo zone. The Carbonera coal zone is typically developed in the western part of the field in the vicinity of Carbonera, in part of Tps. 6 and 7 S., Rs. 103 and $104 \mathrm{~W}$. It is well developed also in the vicinity of Stove Canyon, in the northeast corner of T. 8 S., R. 102 W. A direct correlation of the Stove Canyon beds with those near Carbonera has not been made, but at an intervening locality in secs. 19 and 20, T. 7 S., R. 102 W., carbonaceous shale and thin coal were observed at a similar horizon. Owing to heavy burning it has proved impossible to trace the coal eastward from Stove Canyon. In the vicinity of the Book Cliff mine a zone of carbonaceous shale containing beds of coal occurs about 80 feet above the Cameo zone. Its position suggests a correlation with the Carbonera zone.

The Carbonera zone thus consists of a series of detached coal seams diminishing in number, thickness, and extent from west to east across the field. Direct correlation cannot be made between them, and their assignment has been made on the basis of stratigraphic position. The composition of each set of beds is not unlike that of the Cameo and Palisade zones, but on a smaller scale. Most of them do not extend beyond one or two townships, and for this reason the details of their composition and correlation are given in the township descriptions.

The Carbonera coal at Carbonera is of bituminous rank and not unlike the coal from the other zones. The ash content is somewhat higher, owing to small bedded impurities such as flattened mudstone pellets on bedding surfaces and some disseminated pyrite. However, the sulphur content is not greater than that of the other beds. The coal has a good cubical cleavage, which gives rise to a blocky structure. It stands up very well under handling, and there is little checking or slacking on exposure. Practically all of the dust and fine material derived from the lumps by handling is angular.

\section{BURNING OF COAL BEDS}

Some portion of the outcrop of every valuable coal zone in the Book Cliffs field of Colorado has been affected by burning. The Carbonera and Cameo zones are most affected, especially along the cliff front between Salt Wash and West Salt Creek. The Cameo zone is completely burned out in the parts of T. 1 N., R. 1 E., where it overlies the dip slope of the Rollins sandstone. Between East and West Salt Creeks the outcrops of the Palisade zone have been burned wherever the bench between the coal outcrop and the cliff 
rim is wide enough to prevent too rapid erosion. Whether the fires originated by spontaneous combustion or were caused by lightning is a matter for conjecture. No doubt they began at different times and places and at different horizons. Burning in the Palisade zone could not possibly have induced burning in the Cameo zone, nor could any burning bed conceivably have ignited underlying coal. The fires spread laterally and slowly along or behind the line of outcrop. They may have been checked by ground water in the larger valleys. Such checking may account for the confinement of the principal burned areas to the cliff face between the valleys. Where the intervals between thick beds of coal were not too great, as between the Cameo and Carbonera, or within each individual zone, combustion of the higher seams may have been induced by burning of the lower.

Burning is most extensive upon the massive spurs and may extend back of the nose for several hundred feet or to the base. This is due to burning through from the opposite walls. Burning under such conditions is not an index to the depth of burning behind an unbroken front. Present-day erosion has trenched through the clinker masses in the heads of most of the reentrants, and most of the coal sections studied occupy such positions.

The extent and depth of burning at any locality along the cliffs are governed by the thickness and quality of the coal, its proximity to overlying beds which are also ignited, and the thickness and lithologic character of the cover rock. In the Carbonera and Cameo zones all three of these factors are effective. Each contains thick seams of good bituminous coal, as well as numerous thinner seams of coal and much highly carbonaceous shale, which occasionally has also burned. The interval between the upper bench of the Cameo and the basal Carbonera is usually not more than 40 feet, a thickness insufficient to check the upward trend of the burning. However, the relatively high dips normal to the field cause the coals to pass within a short distance under thick cover, and this has served to preserve much coal. In areas of thin cover the bed is usually entirely destroyed over local areas after the first ignition, but thick cover tends to produce intermittent burning, as an erosional interval is required to prepare the outcrop for each successive burning.

Several very thick masses of clinker have been produced by intermittent burning. In the northeast corner of T. 8 S., R: $102 \mathrm{~W}$., there are sheer walls of clinker 170 feet high; in the southeast corner of sec. 1 , in the same township, the main body of clinker rises 130 to 150 feet above the base of the Cameo zone, and locally tongues of baked rock extend 80 or 100 feet higher. 
Burning not only destroys a great deal of coal, but the heat from the fire may drive off the volatile matter from adjacent unburned coal, thus rendering it worthless. ${ }^{72}$ Coal beds in the Book Cliffs field are now reported to be burning in two localities. The Cameo seam in the Book Cliff mine became ignited some years ago, and after futile efforts to wall off the fire the mine was sealed. A seam that is probably the Cameo is burning in an abandoned mine on the south side of Coal Canyon near the closure of the bed. The effect is not noticeable in warm weather, but in the fall and winter some vapor can be seen rising from crevices in the earth. This fire has been burning for many years and is said to have been started by local wagon miners building a fire on the mine floor while they were taking out coal. Mr. C. W. Wilson, of the Garmesa ranch, reports that grass over the heated area remains green during the winter, and that the locality is a favorite winter range for deer.

\section{CHEMICAL COMPOSITION OF THE COAI}

Descriptions of the physical character of the coal have been included in the general description of each bed. The following tables of analyses give the chemical composition of coal samples recently collected from the Book Cliffs field. Other analyses of coal from this and the nearer competitive regions are given in previously published reports. ${ }^{73}$ Clark $^{74}$ gives the following explanation and interpretation of the coal analyses in his report on the Castlegate district:

Table 1 gives analyses of individual samples collected inside the mines and there sealed in air-tight cans, which were shipped to the Pittsburgh laboratory of the United States Bureau of Mines. These analyses show the condition of the coal in the mine away from air and rapid changes in temperature. * * * Because the mined coal is necessarily extracted without so great care as is used in taking samples from the face of a bed in the mine, *** the mine sample usually indicates a lower ash content and higher heating value than can be expected in commercial shipments, hence it represents coal that can be produced commercially only under the most favorable conditions. Furthermore, commercial shipments sampled at their destination are likely to contain either more or less moisture than the coal in the mine, depending upon the amount of moisture in the bed, the size of the coal, and the weather conditions during transit.

\footnotetext{
${ }^{2}$ Bowie, Alexander, The burning of coal beds in place: Am. Inst. Min. Eng. Trans., vol. 48 , p. 181,1915 .

is Richardson, G. B., Reconnaissance of the Book Cliffs coal field, between Grand River, Colo., and Sunnyside, Utah: U.S. Geol. Survey Bull. 371, pp. 44-45, 1909. Woodruff, E. G., The coal resources of Gunnison Valley, Mesa and Delta Counties, Colo.: U.S. Geol. Survey Bull. 471, p. 571, 1912. Lee, W. T., Coal flelds of Grand Mesa and the West Elk Mountains, Colo. : U.S. Geol. Survey Bull. 510, pp. 201-210. 1912. Campbell, M. R., The Twentymile Park district of the Yampa coal fleld, Routt County, Colo.: U.S. Geol. Survey Bull. 748, pp. 70-78, 1923. Clark, F. R.. Economic geology of the Castlegate, Wellington, and Sunnyside quadrangles, Carbon County, Utah: U.S. Geol. Survey Bull. 793, pp. 83-97, 1928. Fieldner, A. C., and others, Analyses of mine samples [of coals in Utah] : U.S. Bur. Mines Tech. Paper 345, pp. 23-85, 1925.

${ }^{74}$ Clark, F. R., op. cit., pp. 81-82.
} 
In the table below the analyses are given in three forms, marked A, B, and C. Analysis A represents the sample as it comes from the mine; analysis $\mathrm{B}$ represents the coal after all moisture has been eliminated; and analysis $\mathrm{C}$ represents the coal after all moisture and ash have been theoretically removed. $\mathrm{B}$ and $\mathrm{C}$ are obtained from A by recalculation.

Analyses of coal samples from Book Cliffs coal field, Colorado

\begin{tabular}{|c|c|c|c|c|c|c|c|c|c|c|c|c|c|}
\hline \multirow[b]{2}{*}{$\begin{array}{l}\text { Laboratory } \\
\text { no. }\end{array}$} & \multirow[b]{2}{*}{$\begin{array}{l}\text { Air- } \\
\text { dry- } \\
\text { ing } \\
\text { loss }\end{array}$} & \multirow[b]{2}{*}{$\begin{array}{l}\text { Form } \\
\text { of an- } \\
\text { alysis }\end{array}$} & \multicolumn{4}{|c|}{ Proximate } & \multicolumn{5}{|c|}{ Ultimate } & \multicolumn{2}{|c|}{ Heating value } \\
\hline & & & $\begin{array}{c}\text { Mois- } \\
\text { ture }\end{array}$ & $\begin{array}{c}\text { Vola- } \\
\text { tile } \\
\text { matter }\end{array}$ & $\begin{array}{c}\text { Fixed } \\
\text { car- } \\
\text { bon }\end{array}$ & Ash & $\begin{array}{l}\text { Sul- } \\
\text { phur }\end{array}$ & $\begin{array}{l}\text { By- } \\
\text { dro- } \\
\text { gen }\end{array}$ & $\begin{array}{l}\text { Car- } \\
\text { bon }\end{array}$ & $\begin{array}{c}\text { Nitro- } \\
\text { gen }\end{array}$ & $\begin{array}{c}\text { Oxy- } \\
\text { gen }\end{array}$ & $\begin{array}{c}\text { Calo- } \\
\text { ries }\end{array}$ & $\begin{array}{c}\text { British } \\
\text { ther. } \\
\text { mal } \\
\text { units }\end{array}$ \\
\hline & 1.9 & $\begin{array}{l}\mathrm{A} \\
\mathrm{B} \\
\mathrm{C}\end{array}$ & \begin{tabular}{r}
7.34 \\
\hdashline \\
\end{tabular} & $\begin{array}{l}36.15 \\
39.01 \\
43.49\end{array}$ & $\begin{array}{l}46.97 \\
50.69 \\
\mathbf{5 6 . 5 1}\end{array}$ & \begin{tabular}{|c}
9.54 \\
10.30 \\
\hdashline$\ldots .$.
\end{tabular} & $\begin{array}{r}0.58 \\
.63 \\
.70\end{array}$ & & & & & $\begin{array}{l}6,453 \\
7,061 \\
7,872\end{array}$ & $\begin{array}{l}11,777 \\
12,710 \\
14,170\end{array}$ \\
\hline $28918 \ldots$ & 1.9 & $\begin{array}{l}\mathbf{A} \\
\mathbf{B} \\
\mathbf{C}\end{array}$ & $\begin{array}{r}7.20 \\
\end{array}$ & $\begin{array}{l}36.88 \\
39.75 \\
43.61\end{array}$ & $\begin{array}{l}47.70 \\
51.40 \\
56.30\end{array}$ & $\begin{array}{l}8.21 \\
8.85\end{array}$ & $\begin{array}{l}.59 \\
.63 \\
.69\end{array}$ & & & & & $\begin{array}{l}6,676 \\
7,194 \\
7,893\end{array}$ & $\begin{array}{l}12,017 \\
12,949 \\
14,207\end{array}$ \\
\hline $28919_{\ldots}$ & 1.9 & $\begin{array}{l}\mathrm{A} \\
\mathrm{B} \\
\mathrm{C}\end{array}$ & \begin{tabular}{r}
7.15 \\
\hdashline \\
\end{tabular} & $\begin{array}{l}36.76 \\
39,59 \\
43.78\end{array}$ & $\begin{array}{l}47.20 \\
50.84 \\
56.22\end{array}$ & $\begin{array}{l}8.89 \\
9.57\end{array}$ & $\begin{array}{l}.57 \\
.61 \\
.67\end{array}$ & $\begin{array}{l}5.42 \\
4.99 \\
5.52\end{array}$ & $\begin{array}{l}67.64 \\
72.85 \\
80.56\end{array}$ & $\begin{array}{l}1.40 \\
1.51 \\
1.67\end{array}$ & $\begin{array}{l}16.08 \\
10.47 \\
11.58\end{array}$ & $\begin{array}{l}6,608 \\
7,115 \\
7,868\end{array}$ & $\begin{array}{l}11,891 \\
12,807 \\
14,162\end{array}$ \\
\hline A 4950... & 5.8 & $\begin{array}{l}\mathbf{A} \\
\mathbf{B} \\
\mathbf{C}\end{array}$ & $\begin{array}{c}9.9 \\
\\
\end{array}$ & $\begin{array}{l}35.4 \\
39.20 \\
42.00\end{array}$ & $\begin{array}{l}48.9 \\
54.3 \\
58.0\end{array}$ & $\begin{array}{l}5.8 \\
6.5\end{array}$ & $\begin{array}{l}.80 \\
.90 \\
.90\end{array}$ & $\begin{array}{l}5.8 \\
5.3 \\
5.6\end{array}$ & $\begin{array}{l}67.8 \\
75.2 \\
80.4\end{array}$ & $\begin{array}{l}1.60 \\
1.80 \\
1.90\end{array}$ & $\begin{array}{l}18.20 \\
10.30 \\
11.2\end{array}$ & $\begin{array}{l}6,733 \\
7,467 \\
7,983\end{array}$ & $\begin{array}{l}12,120 \\
13,440 \\
14,370\end{array}$ \\
\hline A4951... & 7.1 & $\begin{array}{l}\mathrm{A} \\
\mathrm{B} \\
\mathrm{C}\end{array}$ & 10.4 & $\begin{array}{l}34.7 \\
38.8 \\
43.9\end{array}$ & $\begin{array}{l}: 44.4 \\
49.4 \\
56.1\end{array}$ & \begin{tabular}{l}
10.5 \\
11.8 \\
\hdashline
\end{tabular} & $\begin{array}{l}.60 \\
.70 \\
.70\end{array}$ & $\begin{array}{l}5.7 \\
5.1 \\
5.7\end{array}$ & $\begin{array}{l}62.2 \\
69.4 \\
78.7\end{array}$ & $\begin{array}{l}1.3 \\
1.4 \\
1.6\end{array}$ & $\begin{array}{l}19.7 \\
11.6 \\
13.3\end{array}$ & & $\begin{array}{l}11,050 \\
12,330 \\
13,980\end{array}$ \\
\hline A24794_. & 5.6 & $\begin{array}{l}\mathbf{A} \\
\underset{\mathbf{C}}{\mathrm{B}}\end{array}$ & \begin{tabular}{c}
9.4 \\
\hdashline \\
\end{tabular} & $\begin{array}{l}36.9 \\
40.7 \\
43.6\end{array}$ & $\begin{array}{l}47.8 \\
52.8 \\
56.4\end{array}$ & $\begin{array}{l}5.9 . \cdots \\
6.5\end{array}$ & $\begin{array}{l}1.1 \\
1.2 \\
1.3\end{array}$ & & & & & $\begin{array}{l}6,733 \\
7,428 \\
7,944\end{array}$ & $\begin{array}{l}12,120 \\
13,370 \\
14,300\end{array}$ \\
\hline A24916 & 2.7 & $\begin{array}{l}\mathbf{A} \\
\mathbf{B} \\
\mathbf{C}\end{array}$ & $\begin{array}{c}8.5 \\
\\
\end{array}$ & $\begin{array}{l}36.6 \\
40.0 \\
42.9\end{array}$ & $\begin{array}{l}48.6 \\
53.2 \\
57.1\end{array}$ & $\begin{array}{l}6.3 \\
6.8\end{array}$ & $\begin{array}{l}.7 \\
.7 \\
.8\end{array}$ & & & & & $\begin{array}{l}6,783 \\
7,411\end{array}$ & $\begin{array}{l}12,210 \\
13,340\end{array}$ \\
\hline A40969_..... & 5.4 & $\begin{array}{l}\mathbf{A} \\
\mathbf{B} \\
\mathbf{C}\end{array}$ & 8.0 & $\begin{array}{l}36.1 \\
39.2 \\
41.4\end{array}$ & $\begin{array}{l}51.2 \\
55.7 \\
58.6\end{array}$ & $\begin{array}{l}4.7 \\
5.1\end{array}$ & $\begin{array}{l}.7 \\
.7 \\
.8\end{array}$ & $\begin{array}{l}5.9 \\
5.5 \\
5.8\end{array}$ & $\begin{array}{l}69.9 \\
76.0 \\
80.2\end{array}$ & $\begin{array}{l}1.8 \\
1.9 \\
2.0\end{array}$ & $\begin{array}{l}17.0 \\
10.8 \\
11.2\end{array}$ & & $\begin{array}{l}12,540 \\
13,630 \\
14,370\end{array}$ \\
\hline A2354 & 1.8 & $\begin{array}{l}\mathbf{A} \\
\mathbf{B} \\
\mathbf{C}\end{array}$ & & $\begin{array}{l}38.1 \\
41.0 \\
44.4\end{array}$ & $\begin{array}{l}47.9 \\
51.4 \\
55.6\end{array}$ & $\begin{array}{l}7.0 \\
7.6\end{array}$ & $\begin{array}{l}.7 \\
.8 \\
.8\end{array}$ & $\begin{array}{l}5.6 \\
5.2 \\
5.6\end{array}$ & $\begin{array}{l}68.4 \\
73.6 \\
79.7\end{array}$ & $\begin{array}{l}1.6 \\
1.7 \\
1.9\end{array}$ & $\begin{array}{l}16.7 \\
11.1 \\
12.0\end{array}$ & & $\begin{array}{l}12,170 \\
13,090 \\
14,160\end{array}$ \\
\hline A 23543 & 1.9 & $\begin{array}{l}\stackrel{\mathrm{A}}{\mathrm{B}} \\
\mathrm{C}\end{array}$ & & $\begin{array}{l}37.2 \\
40.4 \\
43.4\end{array}$ & $\begin{array}{l}48.4 \\
52.5 \\
56.6\end{array}$ & $\begin{array}{l}6.5 \\
7.1\end{array}$ & $\begin{array}{l}.7 \\
.7 \\
.8\end{array}$ & $\begin{array}{l}5.7 \\
5.2 \\
5.6\end{array}$ & $\begin{array}{l}68.9 \\
74.8 \\
80.5\end{array}$ & $\begin{array}{l}1.6 \\
1.8 \\
1.9\end{array}$ & $\begin{array}{l}16.6 \\
10.4 \\
11.2\end{array}$ & & $\begin{array}{l}12,240 \\
13,300 \\
14,310\end{array}$ \\
\hline A24792 & 4.3 & $\begin{array}{l}\mathrm{A} \\
\mathrm{B} \\
\mathrm{C}\end{array}$ & & $\begin{array}{l}35.1 \\
38.1 \\
41.2\end{array}$ & $\begin{array}{l}50.1 \\
54.3 \\
58.8\end{array}$ & $\begin{array}{l}7.0 \\
7.6\end{array}$ & $\begin{array}{l}.70 \\
.70 \\
.80\end{array}$ & & & & & & $\begin{array}{l}11,940 \\
12,950 \\
14,010\end{array}$ \\
\hline A24793.. & 3.1 & $\begin{array}{l}\mathbf{A} \\
\mathbf{B} \\
\mathbf{C}\end{array}$ & & $\begin{array}{l}36.4 \\
39.1 \\
43.0\end{array}$ & $\begin{array}{l}48.2 \\
51.9 \\
57.0\end{array}$ & $\begin{array}{l}8.4 \\
9.0\end{array}$ & $\begin{array}{l}.70 \\
.80 \\
.80\end{array}$ & & & & & $\begin{array}{l}6,550 \\
7,044 \\
7,739\end{array}$ & $\begin{array}{l}11,790 \\
12,680 \\
13,930\end{array}$ \\
\hline A24791 & 7.0 & $\begin{array}{l}\mathbf{A} \\
\mathbf{B} \\
\mathbf{C}\end{array}$ & & $\begin{array}{l}35.1 \\
38.9 \\
41.4\end{array}$ & $\begin{array}{l}49.7 \\
54.9 \\
58.6\end{array}$ & $\begin{array}{l}5.6 \\
6.2\end{array}$ & $\begin{array}{l}.60 \\
.70 \\
.70\end{array}$ & & & & & $\begin{array}{l}6,783 \\
7,506 \\
8,000\end{array}$ & $\begin{array}{l}12,210 \\
13,510 \\
14,400\end{array}$ \\
\hline A40970... & 7.7 & $\begin{array}{l}\mathbf{A} \\
\mathbf{B} \\
\mathrm{C}\end{array}$ & & $\begin{array}{l}36.4 \\
40.3 \\
43.4\end{array}$ & $\begin{array}{l}47.5 \\
52.4 \\
56.6\end{array}$ & $\begin{array}{l}6.6 \\
7.3\end{array}$ & $\begin{array}{l}.70 \\
.80 \\
.80\end{array}$ & $\begin{array}{l}6.0 \\
5.4 \\
5.9\end{array}$ & $\begin{array}{l}67.1 \\
74.2 \\
80.0\end{array}$ & $\begin{array}{l}1.7 \\
1.8 \\
2.0\end{array}$ & $\begin{array}{l}17.9 \\
10.5 \\
11.3\end{array}$ & & \\
\hline A 23189. & 2.7 & $\begin{array}{l}\mathrm{A} \\
\mathrm{B} \\
\mathrm{C}\end{array}$ & 12.1 & $\begin{array}{l}35.0 \\
39.8 \\
42.9\end{array}$ & $\begin{array}{l}46.5 \\
53.0 \\
57.1\end{array}$ & $\begin{array}{l}6.4 \\
7.2\end{array}$ & $\begin{array}{l}.6 \\
.7 \\
.8\end{array}$ & $\begin{array}{l}5.8 \\
5.1 \\
5.5\end{array}$ & $\begin{array}{l}65.4 \\
74.4 \\
80.2\end{array}$ & $\begin{array}{l}1.7 \\
1.9 \\
2.1\end{array}$ & $\begin{array}{l}20.1 \\
10.7 \\
11.4\end{array}$ & $\begin{array}{l}6,278 \\
7,144 \\
7,700\end{array}$ & $\begin{array}{l}11,300 \\
12,860 \\
13,860\end{array}$ \\
\hline
\end{tabular}


Analyses of coal samples from Book Cliffs coal field, Colorado-Continued

\begin{tabular}{|c|c|c|c|c|c|c|c|c|c|c|c|c|c|}
\hline \multirow{2}{*}{$\begin{array}{c}\text { Laboratory } \\
\text { no. }\end{array}$} & \multirow{2}{*}{$\begin{array}{l}\text { Air- } \\
\text { dry- } \\
\text { ing } \\
\text { loss }\end{array}$} & \multirow[b]{2}{*}{$\begin{array}{l}\text { Form } \\
\text { of an- } \\
\text { alysis }\end{array}$} & \multicolumn{4}{|c|}{ Proximate } & \multicolumn{5}{|c|}{ Ultimate } & \multicolumn{2}{|c|}{ Heating value } \\
\hline & & & $\begin{array}{c}\text { Mois- } \\
\text { ture }\end{array}$ & $\begin{array}{l}\text { Vola- } \\
\text { tile } \\
\text { matter }\end{array}$ & $\begin{array}{c}\text { Fixed } \\
\text { car- } \\
\text { bon }\end{array}$ & Ash & $\begin{array}{l}\text { Sul- } \\
\text { phur }\end{array}$ & $\begin{array}{l}\text { Hy- } \\
\text { dro- } \\
\text { gen }\end{array}$ & $\begin{array}{l}\text { Car- } \\
\text { bon }\end{array}$ & $\begin{array}{l}\text { Nitro- } \\
\text { gen }\end{array}$ & $\begin{array}{l}\text { Oxy- } \\
\text { gen }\end{array}$ & $\begin{array}{c}\text { Calo- } \\
\text { ries }\end{array}$ & \begin{tabular}{|} 
British \\
ther- \\
mal \\
units
\end{tabular} \\
\hline A40971... & 6.4 & $\begin{array}{l}\mathrm{A} \\
\mathrm{B} \\
\mathrm{C}\end{array}$ & $\begin{array}{r}7.5 \\
\end{array}$ & $\begin{array}{l}34.1 \\
36.8 \\
39.0\end{array}$ & $\begin{array}{l}53.2 \\
57.5 \\
61.0\end{array}$ & $\begin{array}{l}5.2 \\
5.7\end{array}$ & $\begin{array}{r}0.7 \\
.8 \\
.8\end{array}$ & $\begin{array}{l}5.7 \\
5.3 \\
5.6\end{array}$ & $\begin{array}{l}70.9 \\
76.7 \\
81.3\end{array}$ & $\begin{array}{l}1.7 \\
1.9 \\
2.0\end{array}$ & $\begin{array}{r}15.8 \\
9.6 \\
10.3\end{array}$ & $\begin{array}{l}7,072 \\
7,644 \\
8,106\end{array}$ & $\begin{array}{l}12,730 \\
13,760 \\
14,590\end{array}$ \\
\hline A25541....... & 7.2 & $\begin{array}{l}\mathrm{A} \\
\mathrm{B} \\
\mathrm{C}\end{array}$ & $\begin{array}{c}11.4 \\
\end{array}$ & $\begin{array}{l}35.5 \\
40.0 \\
44.8\end{array}$ & $\begin{array}{l}43.7 \\
49.4 \\
55.2\end{array}$ & $\begin{array}{r}9.4 \\
10.6\end{array}$ & $\begin{array}{l}.6 \\
.6 \\
.7\end{array}$ & & & & - & $\begin{array}{l}6,194 \\
6,983 \\
7,817\end{array}$ & $\begin{array}{l}11,150 \\
12,570 \\
14,070\end{array}$ \\
\hline
\end{tabular}

28917. Cameo coal from Cameo mine of Grand Junction Mining \& Fuel Co., in sec. 34 , T. 10 S., R. $98 \mathrm{~W}$., left rib no. 7 , north entry off no. 6 west entry.

28918. Same as 28917 , room 22 off no. 8 west entry, half a mile northwest of mine mouth.

28919. Composite of 28917 and 29918 .

A4950. Anchor coal from Stove Canyon mine, in SE1/4 sec. 11, T. 8 S., R. 102 W. room 1 off main entry, 300 feet from mine mouth.

A4951. Carbonera ('?) coal, Buniger mine, in sec. 1, T. 8 S., R. 102 W., Sept. 26, 1924.

A24794. Anchor coal from Farmers mine, room 800 feet northeast of mine mouth.

A24916. Anchor coal from Stove Canyon mine, room 600 feet west of portal.

A40969. Same as A24916, face of back entry, 150 feet from portal, March 20, 1928.

A23542. Palisade coal from Boyer mine, 100 feet from main entry, July 23, 1926.

A23543. Palisade coal from Williams mine, working face 300 feet from main entry (portal).

A24792. Cameo coal from upper bench, McGinley mine, in entry 150 feet S. $50^{\circ}$ E. of portal.

A24793. Palisade coal from Service mine, 500 feet N. $58^{\circ}$ E. of portal.

A24791. Palisade coal from Hidden Treasure mine, on pillar 350 feet $\mathrm{S}$. $65^{\circ} \mathrm{E}$. of portal, August 10, 1926.

A40970. Palisade (?) coal from Peacock mine, in T. 10 S., R. 99 W., 12 miles north of Grand Junction.

A23189. Palisade coal from Gearbart prospect, in sec. 1, T. 11 S., R. $99 \mathrm{~W}$.

A40971. Same as A24791, rib of no. 1 back entry, 300 feet from mine mouth.

A25541. Carbonera coal from Carbonera mine, first rise 1,400 feet from mine mouth.

For practical purposes the real value of a coal is expressed by the amount of heat it will produce when burned. The heating value is indicated in the table in British thermal units (the quantity of heat required to raise the temperature of 1 pound of water from $62^{\circ}$ to $63^{\circ} \mathrm{F}$.) and in calories (the amount of heat required to raise the temperature of 1 kilogram of water from $141 / 2^{\circ}$ to $1512^{\circ}$ C.). Thus 1 pound of coal from this field is sufficient, when burned under testing conditions, to raise the temperature of 11,000 to 12,000 pounds of pure water $1^{\circ} \mathrm{F}$.

In figure 6 the heating values in British thermal units in the "as received" form of the coals of the Book Cliffs field are compared graphically with one another and with those of coals from some of the adjacent competitive fields.

In a general way the average heating value of the Book Cliffs coals decreases with the rise of the beds in the section. The change is not gradational, and in some places there is greater variation within a bed than there is between overlying and underlying beds. The numerical averages in British thermal units are as follows: Carbonera, 11,000; Cameo, 11,920 ; Palisade, 12,040; Anchor, 12,100.

The degree of carbonization of the coal increases with stratigraphic depth, in accordance with the principle of Hilt's law. 
Within the coal measures the rate of increase corresponds fairly well to the rate determined by Reeves ${ }^{75}$ for the central Appalachian coal basin, the average increase in the percentage of fixed carbon being 0.52 per 100 feet. However, this gradient is not maintained in passing downward through the Mancos shale. The carbon ratios of the Dakota (?) coals encountered in the deep borings below the cliffs average 63.1 percent $;^{76}$ the average of a series of Dakota(?)

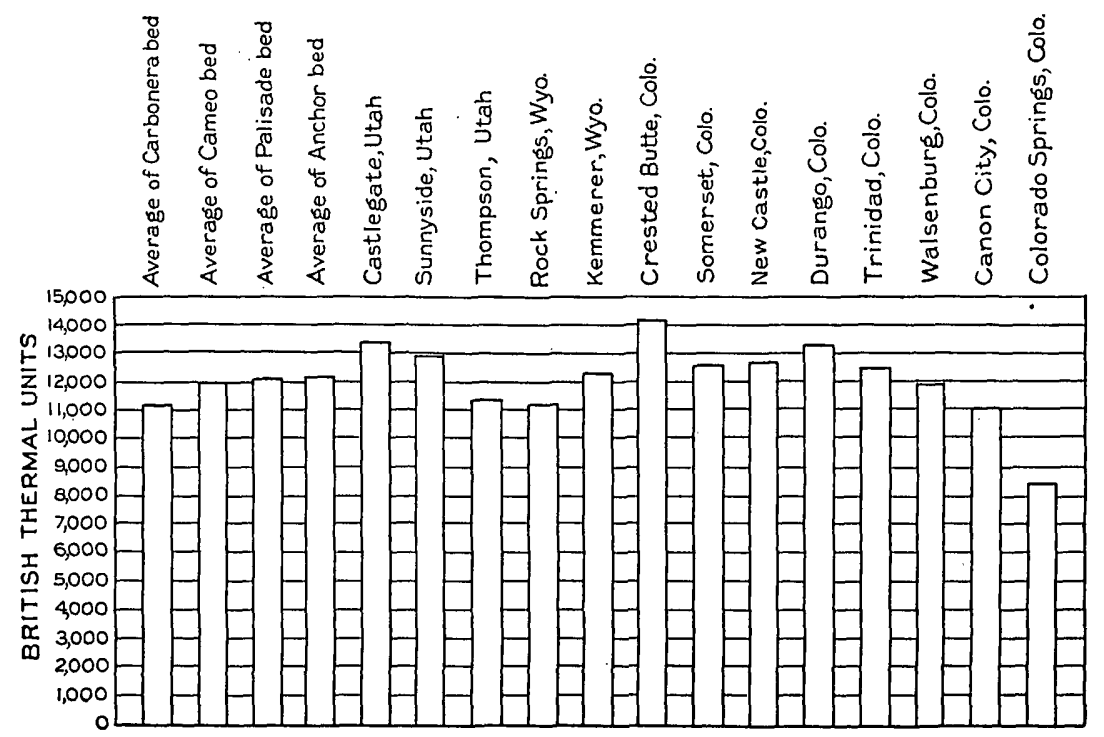

Frgure 6.-Heating value of Book Cliffs coals "as received" and of coals from adjacent regions with which they may come into competition.

coals taken from workings on the outcrop some distance away is 58.8 percent; ${ }^{77}$ and the average of the Dakota(?) coals is 59.7 percent. Selecting the average ratio of the Dakota(?) coals from the deep wells as being nearly in the line of vertical section with the outcropping Anchor coals, and thus more favorable to the comparison, we find a difference of 5.6 percent between this ratio and the average ratio of the Anchor coals. This indicates an increase in the fixed carbon of 0.14 percent to each 100 feet through the Mancos shale. It should be noted that this apparent discrepancy is the result of a single observation, the only; one of this kind possible within the

\footnotetext{
${ }^{75}$ Reeves, Frank, The carbon-ratio theory in the light of Hilt's law: Am. Assoc. Petroleum Geologists Bull., vol. 12, no. 8, p. 801, 1928.

${ }^{70}$ Wilson, J. H., Lithologic character of shale as an index of metamorphism: Am. Assoc. Petroleum Geologists Bull., vol. 10, no. 6, pp. 626, 629, 1926.

${ }^{77}$. Woodruff, E. G., The coal resources of Gunnison Valley, Mesa and Delta Countles, Colo. : U.S. Geol. Survey Bull. 471, p. 571, 1912.
}

$50646-34-7$ 
field. However, it may be of interest to those who contemplate applying the carbon-ratio theory to petroleum exploration in the region. In this connection it should also be noted that the carbon ratio of the Dakota(?) coals serves directly as an index of metamorphism of the sands from which petroleum and gas have been sought.

\section{QUANTITY OF COAL}

An accurate estimate of the underground reserves of any coal field is very difficult, as it must be based chiefly upon the detailed studies of the coal along the outcrops. In many places the outcrops are obscured, and interpolations must be made between the available sections. The estimate decreases in accuracy in proportion to the distance it is projected back from the outcrop. In the preparation of regional estimates certain fundamental stratigraphic problems must be considered, such as variation in trend of ancient coast lines and the persistence of coal-bearing beds.

Although the general principles governing estimates of coal tonnage have been set forth in connection with the classification of public lands by the United States Geological Survey, ${ }^{78}$ brief mention of the factors that apply in particular to this field is necessary. The beds were assumed to extend back from the cliff at least half the length of their cliff outcrop. The minimum thickness of bed considered was 14 inches. Rejection because of bedded impurities was made according to the Geological Survey rule which prescribes that " any parting or bench of bone or impure coal included in a bed injures the value of the bed in amount equal to the thickness of the parting." 79 Application of this rule sometimes causes fairly thick coal seams to be classed as too thin. After the areas of the beds had been delimited, lines of equal thickness were drawn on the coal with 10-inch intervals wherever the data warranted; and where not, the classifiable thickness of the bed at the outcrop was projected back to the theoretical limit of the seam. The coal was assumed to have a specific gravity of 1.34 - the average specific gravity of American bituminous coal. On this basis a seam of coal 1 foot thick will contain $1,831.47$ short tons to the acre, or $1,172,160$ tons to the square mile. One ton of such coal occupies 23.8 cubic feet. ${ }^{80}$ Tonnages were calculated by converting the figure for the average thickness of coal between a pair of equal-thickness lines into tons per acre, and then multiplying by the planimeter area in acres.

\footnotetext{
${ }^{78}$ Smith, G. O., and others, the classification of the public lands: U.S. Geol. Survey Bull. 537, pp. 65-110, 1913.

${ }^{70}$ Idem, p. 70.

${ }^{80}$ Coal miners' poclet book, 11th ed., p. 289, New York, 1916. Figures derived from table "Contents of horizontal coal seams."
} 
Most coal estimates attempt to give only the total original tonnage of the field, or the recoverable tonnage. Such an estimate, though of importance with respect to national fuel economy, is of little interest to the present coal producers and mining engineers, as the greater portion of the tonnage usually lies under so thick a cover that there is small possibility of its being sought under present conditions. In the absence of division of the total tonnage by beds and townships and without topographic maps, it is frequently impossible to determine the tonnage of the portions of the field in which the reserves are more or less immediately available.

In the estimates presented herewith an effort to avoid this diffculty has been made by dividing the area of workable coals of each bed into two parts-an immediate reserve and a future reserve. The inner limit of the immediate reserve is defined by a line arbitrarily drawn upon a coal bed 3,000 feet back from its outcrop. This line does not appear upon the geologic map, but its position may be determined very easily. The immediate reserve area of any bed is thus a strip 3,000 feet or more deep bordering the cliff front over the extent of the bed. The limit selected was purposely made low; but at the present time it more than suffices to include the workings of all but the most extensive mines. The coal beds within this area are under relatively thin cover and are those that will naturally be mined first. They may be readily explored by slopes, drifts, or shallow shafts. In calculating tonnages for this reserve, deductions have been made for the amount the beds have already been depleted by mining.

No effort has been made to estimate the amount of recoverable coal in the field. The local operators are in a far better position to do that than the writer. It is evident, however, that the recovery will not be uniform over the area and will probably be greater from the immediate reserve than from the future reserve. Perhaps an average recovery of 60 percent for the field is not beyond reasonable expectations. Individual estimators interested in the recoverable coals of any particular area should apply the factors warranted by their experience to the tonnage figures given in the table on pages 95-98.

In addition to unavoidable mining losses much coal is carelessly destroyed in most fields by lack of systematic development. The early prospectors are naturally attracted to the thicker, cleaner coals. Not uncommonly these are overlain by thinner coals of similar quality. When the interval between the two beds is not great, the upper bench is almost certain to be ruined for future mining by the operations in the lower bench. Simultaneous mining of both seams is the only practice that will permit the upper coal to be saved. Usually 
this is not feasible during the exploratory period. Such conditions exist at several places in the Book Cliffs field, and in each the coal of the upper bench has been classed as unrecoverable and does not appear in the estimates. Considerable amounts of coal are also ruined by improper mining practices and by intermittent operation.

In the tables of estimates given below the average thickness has been determined as follows: The total estimated tonnage is divided by the total area in acres; the quotient in tons per acre is then converted into thickness of a horizontal seam by dividing by 1,831 (the number of tons per acre in a seam 1 foot thick). The resultant figure is purely theoretical and represents the thickness the bed would have if the coal were distributed evenly over the whole area.

Some discrepancies, due to rounding off the figures, will be noted in the tables, especially in the table showing tonnages of coal mined from the various beds to 1927 (pp. 102-106). In the table of tonnage estimates (pp. 95-99) the variation, however, is less than 10 percent-an order of accuracy much closer than that of the estimates themselves.

No estimates are given for some townships in which there are outcrops of coal. Estimates for those townships are considered unjustifiable, owing to the lack of workable seams. 
QUANTITY OF COAL

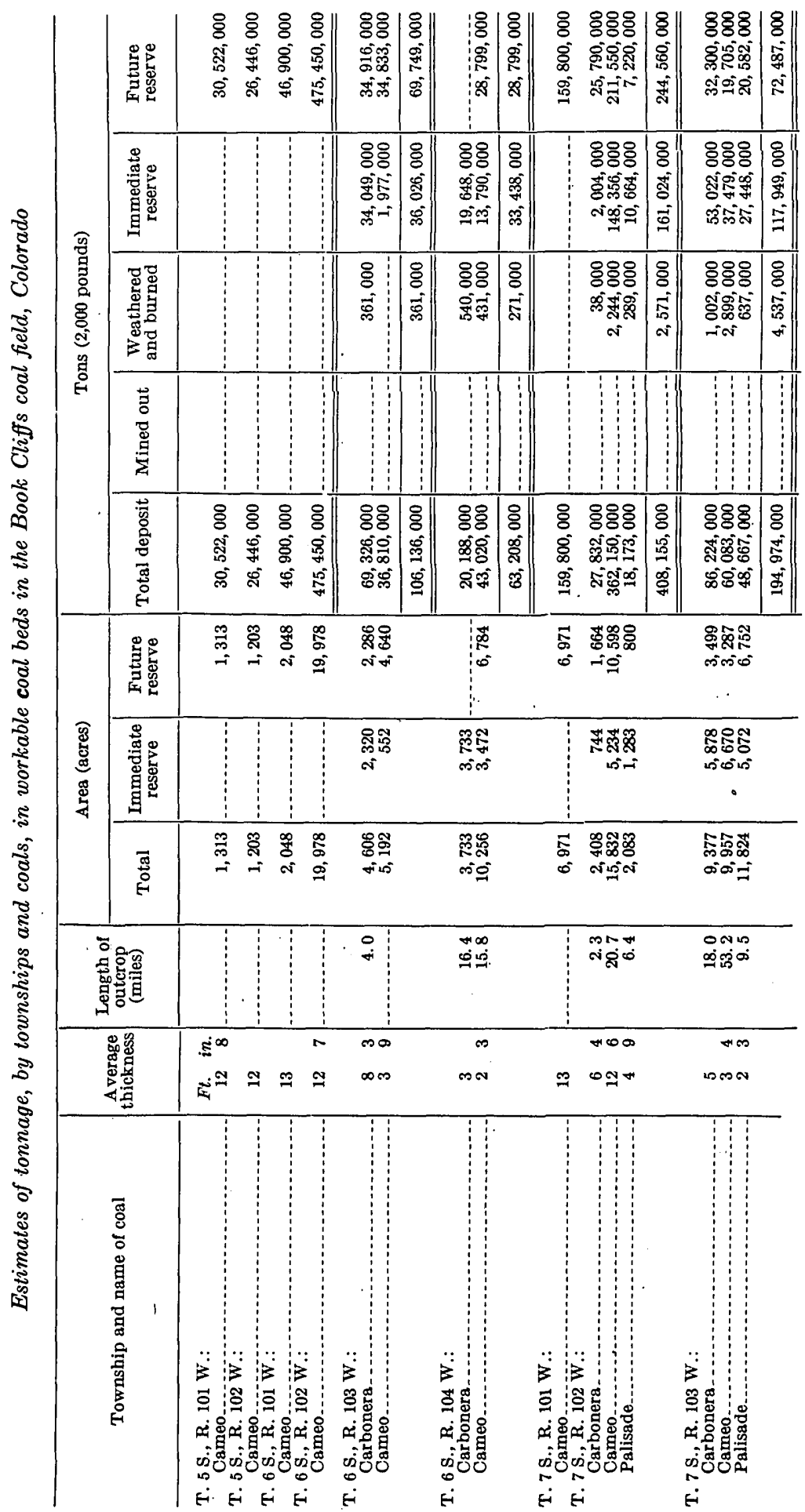




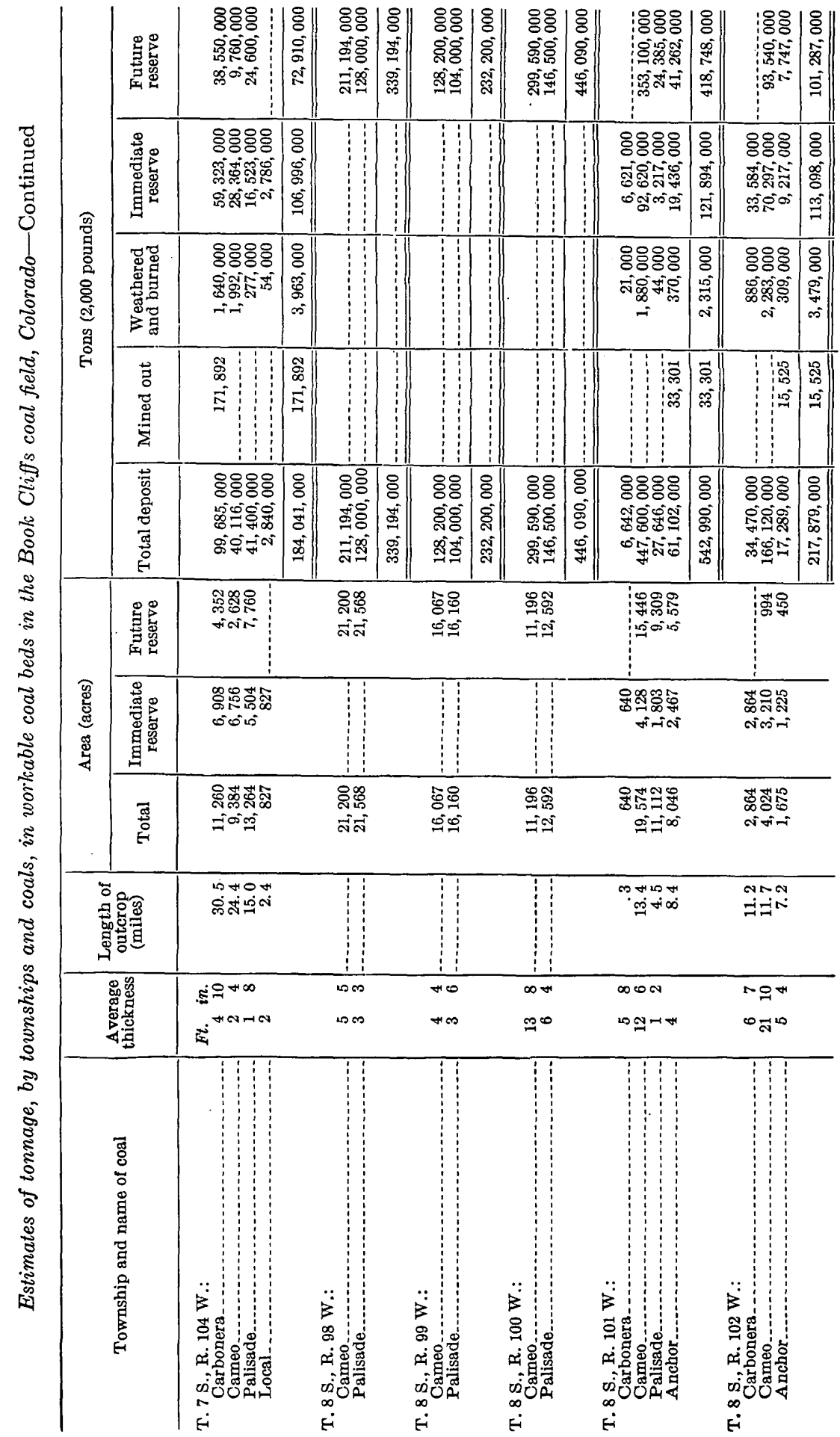




\begin{tabular}{|c|c|c|c|c|c|c|c|c|c|c|c|c|c|c|c|}
\hline $\begin{array}{l:l}8 & \\
0 & \\
8 & \\
8 & \\
+ & 1 \\
& \end{array}$ & 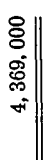 & 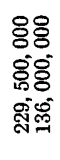 & $\mid$\begin{tabular}{|}
8 \\
8 \\
8 \\
8 \\
0 \\
80 \\
8 \\
0
\end{tabular} & 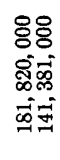 & 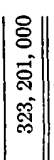 & 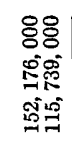 & 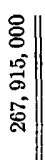 & & & 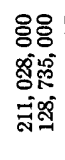 & 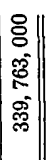 & 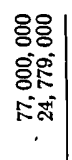 & $\left|\begin{array}{c||}8 \\
8 \\
0 \\
5 \\
5 \\
\vdots \\
0\end{array}\right|$ & & \\
\hline $\begin{array}{c}8 \\
0 \\
-1 \\
\infty \\
\infty\end{array}$ & $\begin{array}{l}8 \\
8 \\
-1 \\
\infty \\
\infty\end{array}$ & & 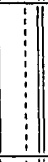 & & 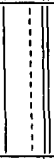 & 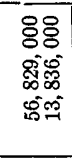 & $\begin{array}{l}0 \\
8 \\
1 \\
0 \\
8 \\
8\end{array}$ & 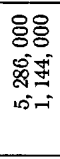 & $\left|\begin{array}{c}8 \\
8 \\
0 \\
9 \\
\vdots \\
0\end{array}\right|$ & $\begin{array}{l:l} & \\
0 & \\
0 & \\
o & \\
0 & \\
= & \end{array}$ & $\begin{array}{l}8 \\
8 \\
\tilde{N} \\
0 \\
= \\
=\end{array}$ & $\begin{array}{l}88 \\
80 \\
80 \\
80.0 \\
70^{\circ} \\
-\infty\end{array}$ & 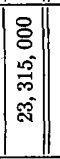 & $\begin{array}{l}80 \\
808 \\
000 \\
00 \\
\text { in }\end{array}$ & \begin{tabular}{|c|}
$\delta$ \\
$\delta$ \\
0 \\
$\infty$ \\
$\infty$ \\
$\infty$ \\
$\infty$
\end{tabular} \\
\hline 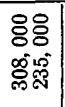 & $\begin{array}{l}8 \\
8 \\
\text { s. } \\
\text { : }\end{array}$ & & & & & 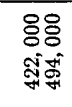 & 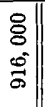 & 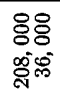 & $\left|\begin{array}{l}8 \\
8 \\
\multirow{3}{*}{}\end{array}\right|$ & \begin{tabular}{l|}
8 \\
$\vdots$ \\
$\Phi$
\end{tabular} & 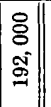 & $\begin{array}{l}88 \\
88 \\
\text { ఖ్రే }\end{array}$ & 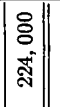 & 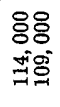 & 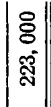 \\
\hline 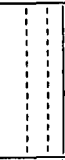 & \begin{tabular}{||l} 
\\
$\vdots$ \\
1
\end{tabular} & & & & & $\begin{array}{l}\text { 윺 } \\
\text { के }\end{array}$ & $\begin{array}{l}\stackrel{0}{=} \\
= \\
=\end{array}$ & $\begin{array}{l:}\vdots \\
\vdots \\
\vdots \\
\vdots \\
\vdots\end{array}$ & & 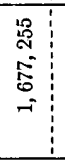 & \begin{tabular}{|c||} 
\\
0 \\
$a$ \\
5 \\
5 \\
-1 \\
-1
\end{tabular} & 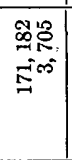 & 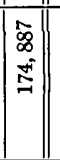 & : & 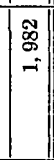 \\
\hline 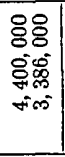 & \begin{tabular}{|l||}
8 \\
8 \\
0 \\
0 \\
0 \\
-1
\end{tabular} & 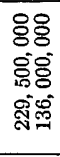 & 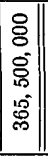 & 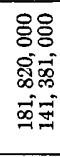 & 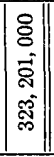 & 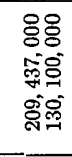 & 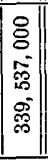 & 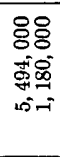 & \begin{tabular}{|c|}
8 \\
8 \\
5 \\
0 \\
0 \\
0
\end{tabular} & 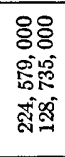 & 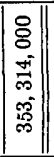 & 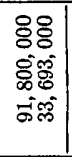 & 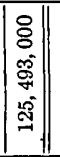 & 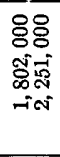 & $\left|\begin{array}{c}8 \\
8 \\
8 \\
8 \\
8 \\
-4\end{array}\right|$ \\
\hline & & 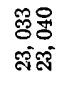 & & $\begin{array}{l}\text { 융: } \\
\text { क्ञसत }\end{array}$ & & 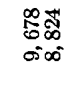 & & & & $\begin{array}{l}\text { 品高 } \\
\text { הत्ञ }\end{array}$ & & 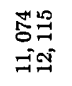 & & & \\
\hline : & & & & & & 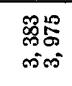 & & 윳동 & & $\stackrel{\overbrace{}}{\Im}$ & & 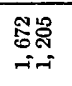 & & 苂 & \\
\hline 아웜 & & 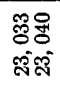 & & $\begin{array}{l}\text { 융ㄹ } \\
\text { \$.స. }\end{array}$ & & 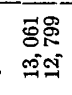 & & 윳동 & & 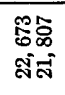 & & 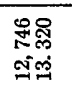 & & శ్రిని & \\
\hline $\begin{array}{l}\text { Win } \\
+\infty \infty \infty\end{array}$ & & & & & & $\begin{array}{l}\text { 오 } \\
\text { 걱 }\end{array}$ & & مo & & \begin{tabular}{l|l}
0 \\
a
\end{tabular} & & $\begin{array}{l}\infty \\
+\rightarrow-1\end{array}$ & & $\begin{array}{l}\text { WN } \\
\text { IiN }\end{array}$ & \\
\hline$\infty$ & & $\infty \infty$ & & Wo & & on & & 0 & & $N$ & & $7^{10}$ & & 0 & \\
\hline or & & חמי & & Wl & & $\infty 10$ & & ฐ્య & & WD & & $\infty \pi$ & & $N+$ & \\
\hline
\end{tabular}

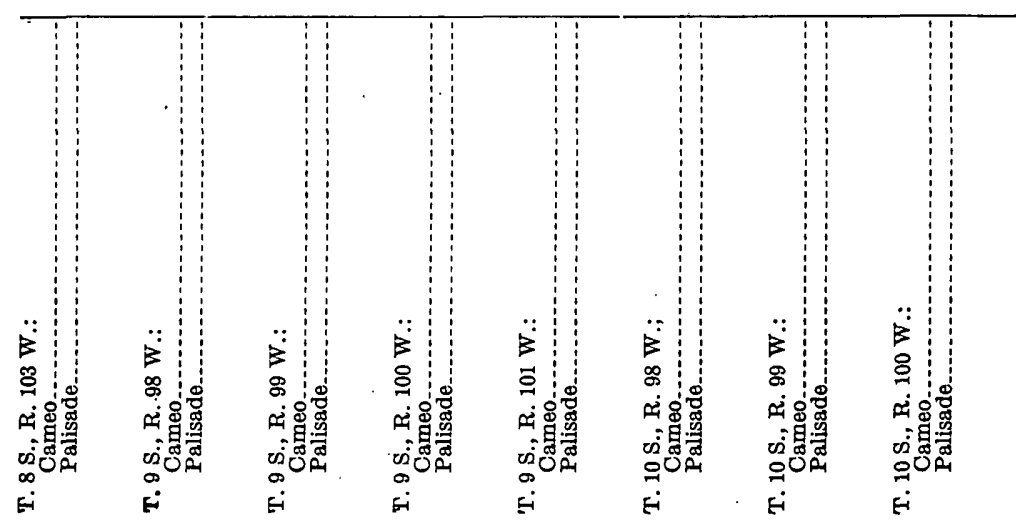




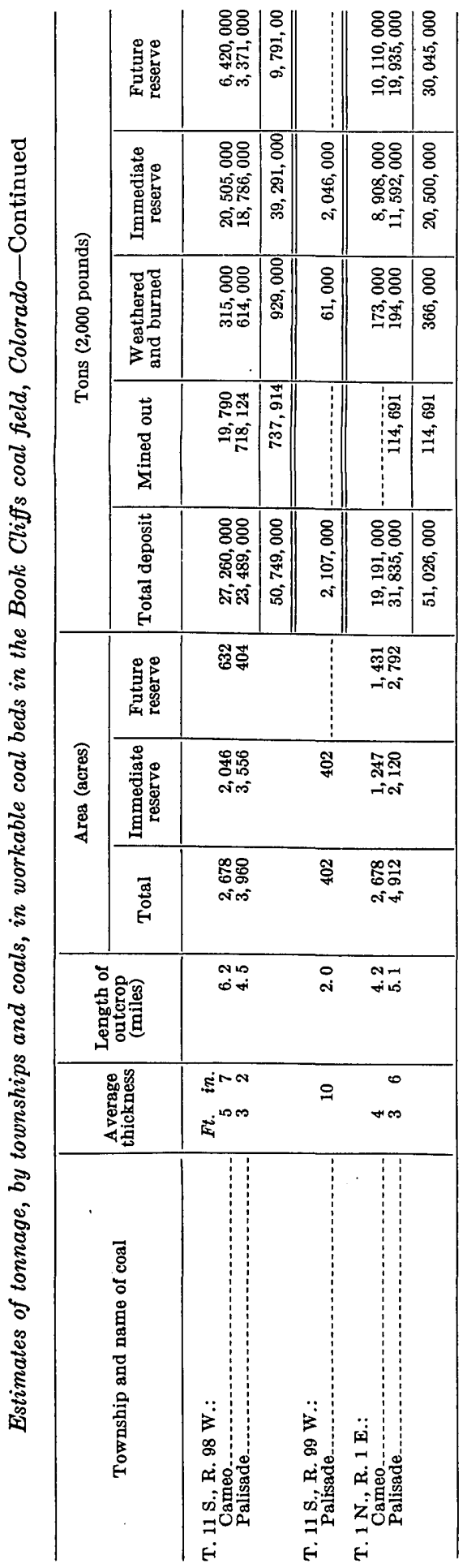




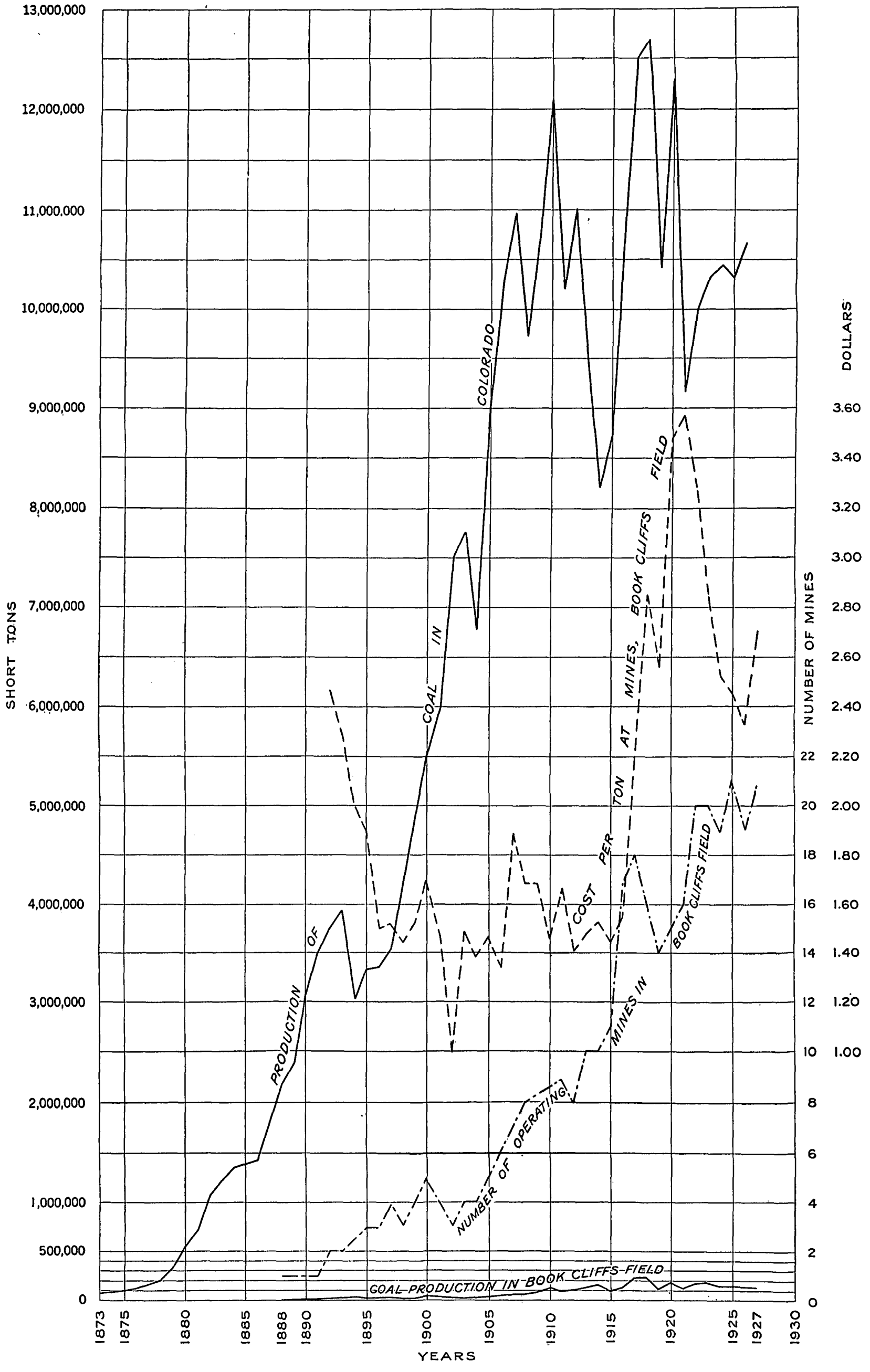

COMPARATIVE STATISTICS OF COAL PRODUCTION. 
Summary of tonnage, estimated by coals, in the Book Cliffs coal field, Colorado

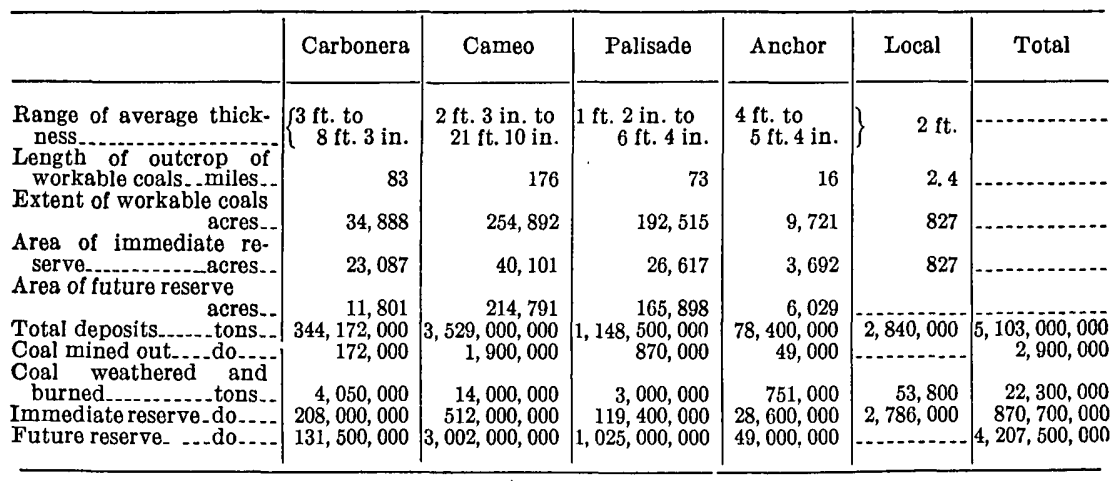

MINING DEVELOPIMENT AND PRODUCTION OF COAL

Records of production of coal in Colorado date back to 1864, when 500 tons was mined. The early production for the State came from Jefferson and Boulder Counties. In 1872 coal was mined in Weld County, and from then on development was rapid, the railroads or subsidiary organizations being the principal operators.

Mesa County, which includes most of the Book Cliffs field in Colorado, became a commercial producer in 1888, though coal had been mined before that time by individuals for domestic use. In its first year of commercial production Mesa County stood next to the last among 17 coal-producing counties, but 38 years later, in 1926, it ranked ninth in a list of 22 counties, the annual output having increased from 300 to 138,268 tons. The population of the county, according to the Census Office, increased from 4,260 in 1890 to 22,280 in 1920 . The 460 -fold gain in coal production is due principally to the growth of coal-consuming industries in Grand Valley, such as canneries and brickyards, and to increase in coal export.

Efforts were made to produce coke in the early days. In 1892 20 tons was made at the Book Cliff mine, and the next year 100 tons. In 1894 and subsequent years no coke was made.

The production of the Book Cliffs field, as compared with that of the State, is shown graphically in plate 13, which also shows the number of operating mines in the field and the cost of coal production at the mines. This figure is less than the price paid by the consumer, but it closely reflects the trend of prices. In the summer of 1926 run-of-mine coal sold for $\$ 4$ a ton at the mine, haulage extra. Lump and nut coal were a little higher. The similarity between the production curves indicates that the industry in this field has adjusted itself readily to the same economic influences that affected State production. There is also a correlation between the cost of coal and the number of operating mines, but the highs 
on the mine curve show a tendency to lag behind the highs of costs and prices. The correlation between production of coal and number of mines is more apparent than real, for the bulk of the coal is produced by a very few mines, whereas the combined tonnage of the other mines is relatively low. Thus in 1926 four mines-the Palisade, Cameo, Carbonera, and Midwest-produced 111,290 tons, or about 81 percent of the total. The data upon which the charts and figures are based were compiled from the reports on Mineral Resources of the United States and from the reports of the Colorado State inspector of coal mines.

Only a few mines have railroad connections. The Carbonera mine is served by the Uintah Railway, which joins the main line of the Denver \& Rio Grande Western Railroad at Mack. The Cameo, Palisade, Midwest, Stokes, and Plateau Valley mines have connections with the Denver \& Rio Grande Western Railroad in the vicinity of Palisade and Cameo. The Book Cliff mine was formerly connected with the town of Grand Junction by the narrow-gage Book Cliff Railroad. The Mount Lincoln and Grand View mines, not operating when the field was visited in 1926 and 1927, had connections with the Denver \& Rio Grande Western Railroad. The mines with railroad connections are the heaviest producers, and all of the coal shipped from the region comes from them. Their production is more steady and less affected seasonally than that of the smaller workings, which supply the local needs. The smaller mines are of two classes. Some are local wagon mines which are worked only in the cooler months, usually by the nearby rancher. The production is usually only a few hundred tons, and development is haphazard. Several men will open the mine in the fall, break down enough coal to last for some time, and then leave, returning when their supply is exhausted. The small mines of the other class operate throughout the year, supplying villages or small industries, such as brickyards, with coal by truck. They are strongly affected seasonally, but their larger contracts enable them to operate through the summer. A typical example of the fluctuations in production of such a mine is shown graphically in figure 7 .

The mining history of the region is indicated in the following table, which is a more detailed analysis of the curves for coal production and number of operating mines in the Book Cliffs field given in plate 13 , with some additional information. Much difficulty was encountered in assigning some of the old mines to their proper coal horizon, also in avoiding duplication and detecting variations in names for any given working. Many of the smaller mines have changed names as often as they have changed hands. This is especially true of the "farmer" mines. The mines from which production has been recorded are listed in chronologic order, 
with the oldest at the top. Among the old mines not listed are the Keystone or Steele mine, in sec. 7, T. 10 S., R. 99 W.; the Bob Cat mine, in sec. 36, T. 9 S., R. 100 W.; the Excelsior mine, a short

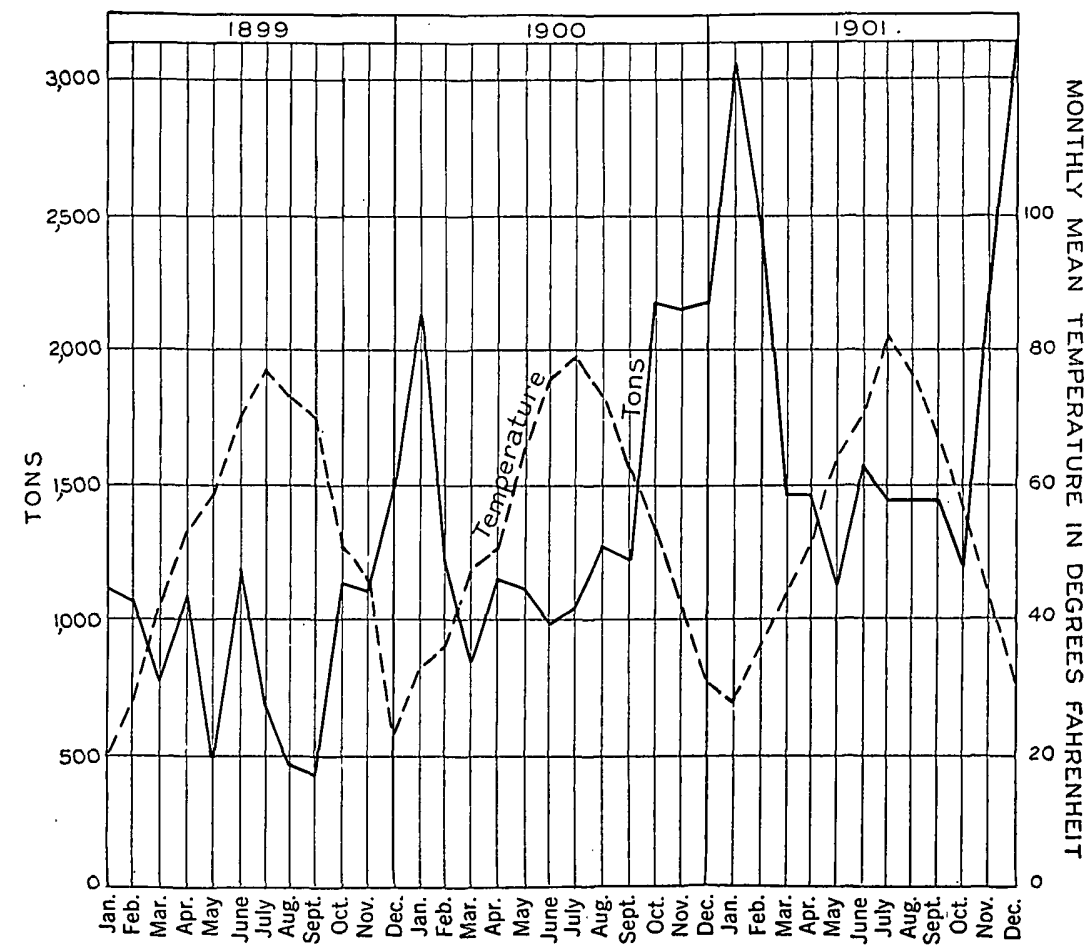

Figune 7.-Seasonal fluctuations in production, Book Cliff mine, 1899-1901. The temperature data are taken from reports of the United States Weather Bureau; the data on coal production from reports of the Colorado State inspector of mines.

distance to the west; the Kiel or Gross mine, which was situated near or may be the present Anchor no. 1; the Nugent, which was situated near or may be the Anchor no. 2; the Johnson and Lane mines, in Coal Canyon; the Corcoran mine; and the Buniger mine. 


\begin{tabular}{|c|c|c|c|c|c|c|c|}
\hline 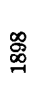 & 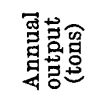 & $\mid \begin{array}{l}1 \\
0 \\
0\end{array}$ & $\begin{array}{l}888 \\
1510^{\circ}\end{array}$ & $\stackrel{\circ}{\circ}$ & 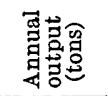 & 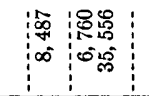 & 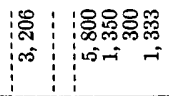 \\
\hline & 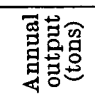 & 衿 & 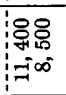 & 今్ & 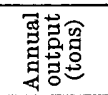 & 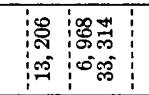 & 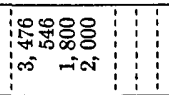 \\
\hline 勇 & 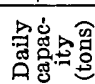 & 8 & 요 & $\stackrel{8}{9}$ & 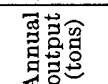 & 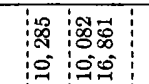 & 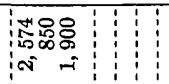 \\
\hline & 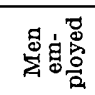 & พั่ & $\infty^{\infty}$ & 兽 & 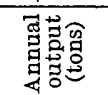 & 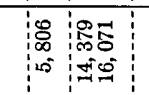 & 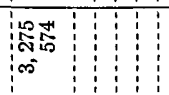 \\
\hline \multirow{2}{*}{$\stackrel{\mathscr{ٌ}}{\sim}$} & 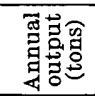 & : & $\begin{array}{l}\text { iog } \\
\text { 욤 } \\
\text { sin }\end{array}$ & \multirow{2}{*}{ 菏 } & 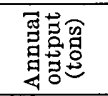 & 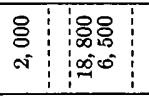 & \\
\hline & 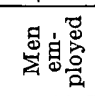 & ה & $\infty^{\circ}$ & & 起总总 & \begin{tabular}{l|ll}
10 & $\infty$ \\
& 0 &
\end{tabular} & io \\
\hline \multirow{2}{*}{ 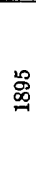 } & 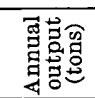 & $\begin{array}{l}\infty \\
\infty \\
\infty\end{array}$ & $\begin{array}{l}80 \\
\infty \\
\infty \\
\infty \\
\infty\end{array}$ & 怘 & 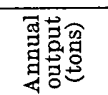 & 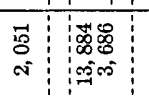 & is \\
\hline & 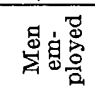 & 吕 & 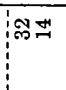 & శ్ & 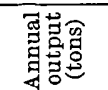 & 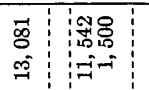 & \\
\hline \multirow{2}{*}{ 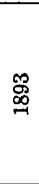 } & 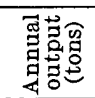 & 8 & 8 & \multirow{3}{*}{$\overrightarrow{\mathrm{g}}$} & 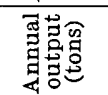 & 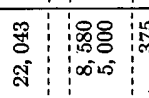 & \\
\hline & 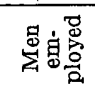 & & $\begin{array}{l}\infty \\
\end{array}$ & & 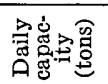 & $\begin{array}{l:ll}\circ & \circ \\
& 0\end{array}$ & \\
\hline \multirow{2}{*}{ 芯 } & 可总高 & 8 & : & & 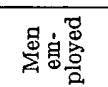 & \begin{tabular}{l|l|l}
2 & 요 \\
\end{tabular} & \\
\hline & 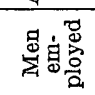 & 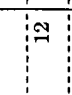 & 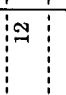 & \multirow{3}{*}{ 怘 } & 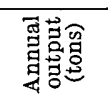 & 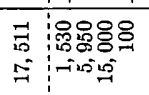 & \\
\hline \multirow{2}{*}{ 兽 } & 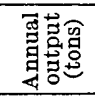 & $\begin{array}{l}8 \\
0\end{array}$ & & & 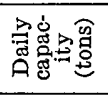 & 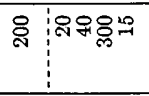 & \\
\hline & 递 & $\infty$ & & & 密宽尊 & ম & \\
\hline \multirow{2}{*}{$\stackrel{\not 0}{\not}$} & 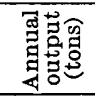 & $8:$ & & \multirow{2}{*}{$\stackrel{\stackrel{\circ}{\circ}}{\stackrel{\sim}{\sim}}$} & 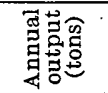 & 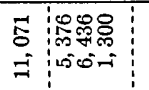 & \\
\hline & 离宽总 & $m$ & & & 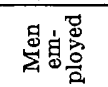 & $=1$ & \\
\hline & 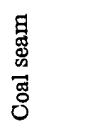 & 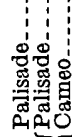 & 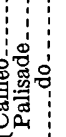 & & 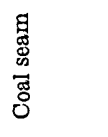 & 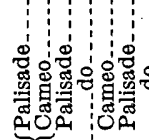 & 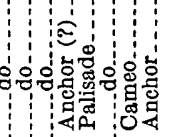 \\
\hline & 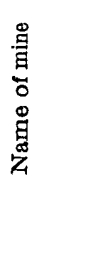 & 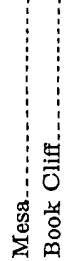 & 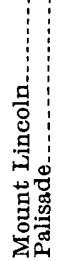 & & 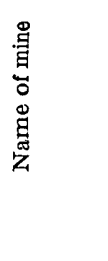 & 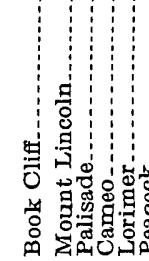 & 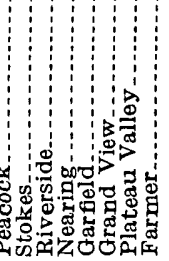 \\
\hline
\end{tabular}




\begin{tabular}{|c|c|c|c|c|}
\hline \multirow{3}{*}{$\stackrel{m}{a}$} & 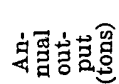 & 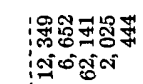 & 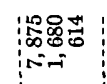 & 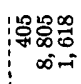 \\
\hline & 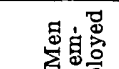 & :퐁 & $F^{N+}$ & ๙ \\
\hline & 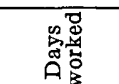 & 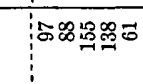 & 祸尔 & 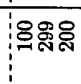 \\
\hline \multirow{3}{*}{$\underset{\Xi}{\Xi}$} & 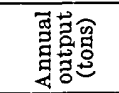 & 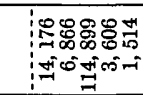 & 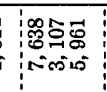 & 总哭 \\
\hline & 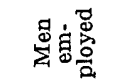 & 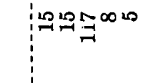 & 0 & inn \\
\hline & 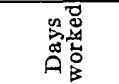 & 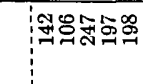 & 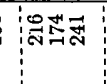 & बิ \\
\hline \multirow{3}{*}{ ఖ } & 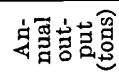 & 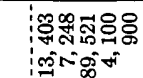 & 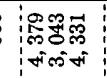 & 周 \\
\hline & 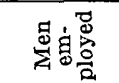 & : & OON & $i_{\infty}$ \\
\hline & 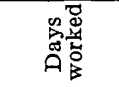 & 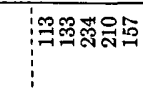 & : & 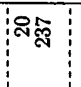 \\
\hline \multirow{3}{*}{$\underset{\Xi}{\Xi}$} & 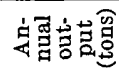 & $\begin{array}{l}\text { iNmo: } \\
\text { oñ } \\
\text { =0 }\end{array}$ & 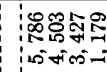 & \\
\hline & 总腺总 & :퐁 & Nnom & \\
\hline & 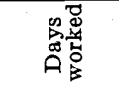 & : & 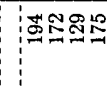 & \\
\hline \multirow{3}{*}{$\vec{\Xi}$} & 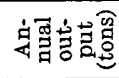 & 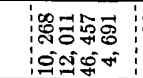 & 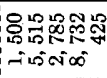 & \\
\hline & 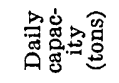 & 이용 & 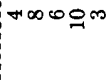 & \\
\hline & 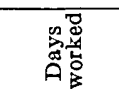 & க요요 & 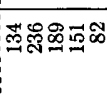 & \\
\hline$\stackrel{\circ}{\stackrel{9}{\Xi}}$ & 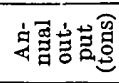 & 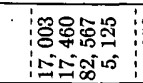 & 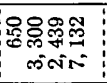 & \\
\hline 怘 & 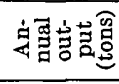 & 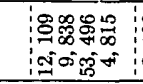 & 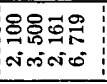 & \\
\hline & 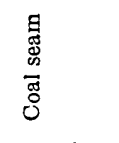 & 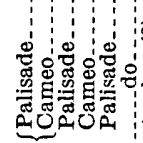 & 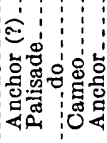 & 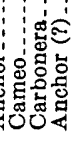 \\
\hline & 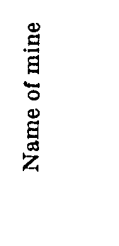 & 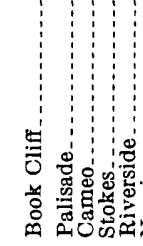 & 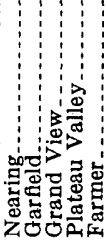 & 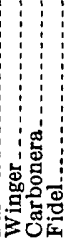 \\
\hline
\end{tabular}




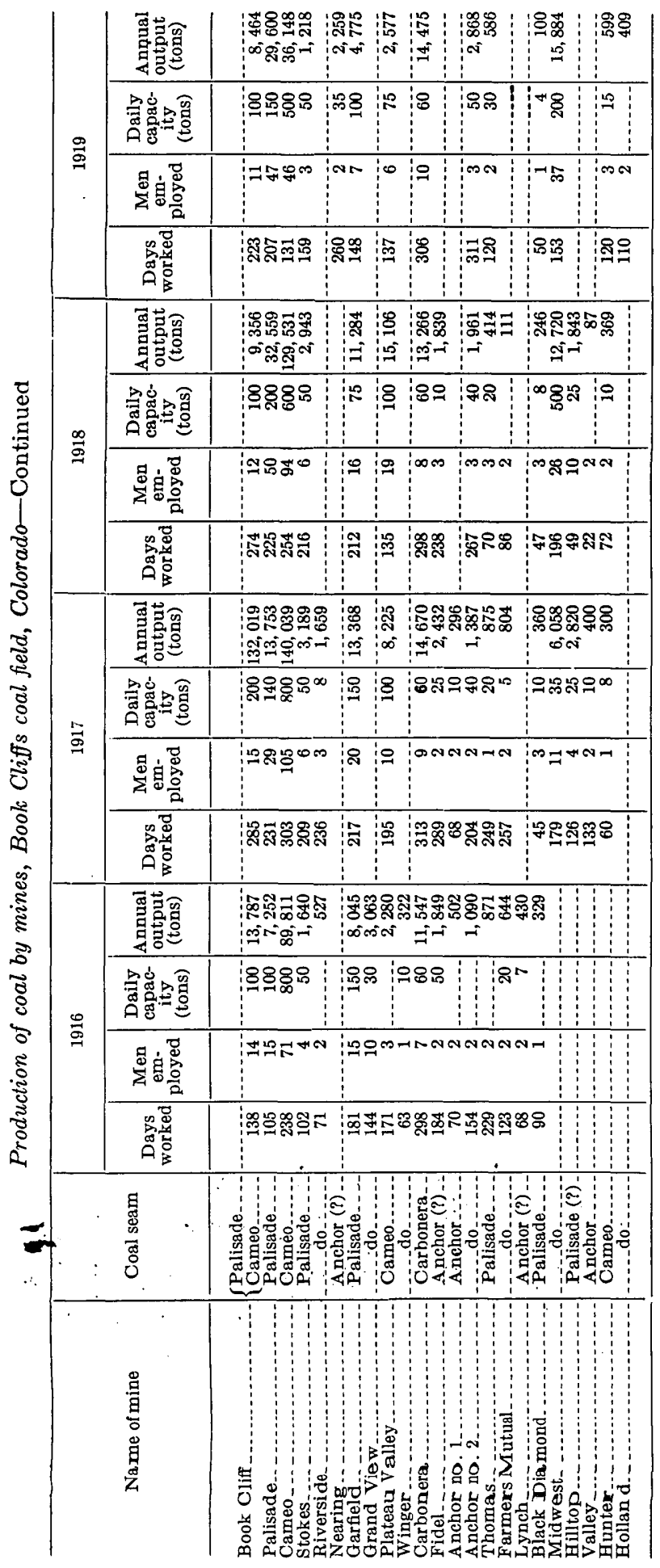




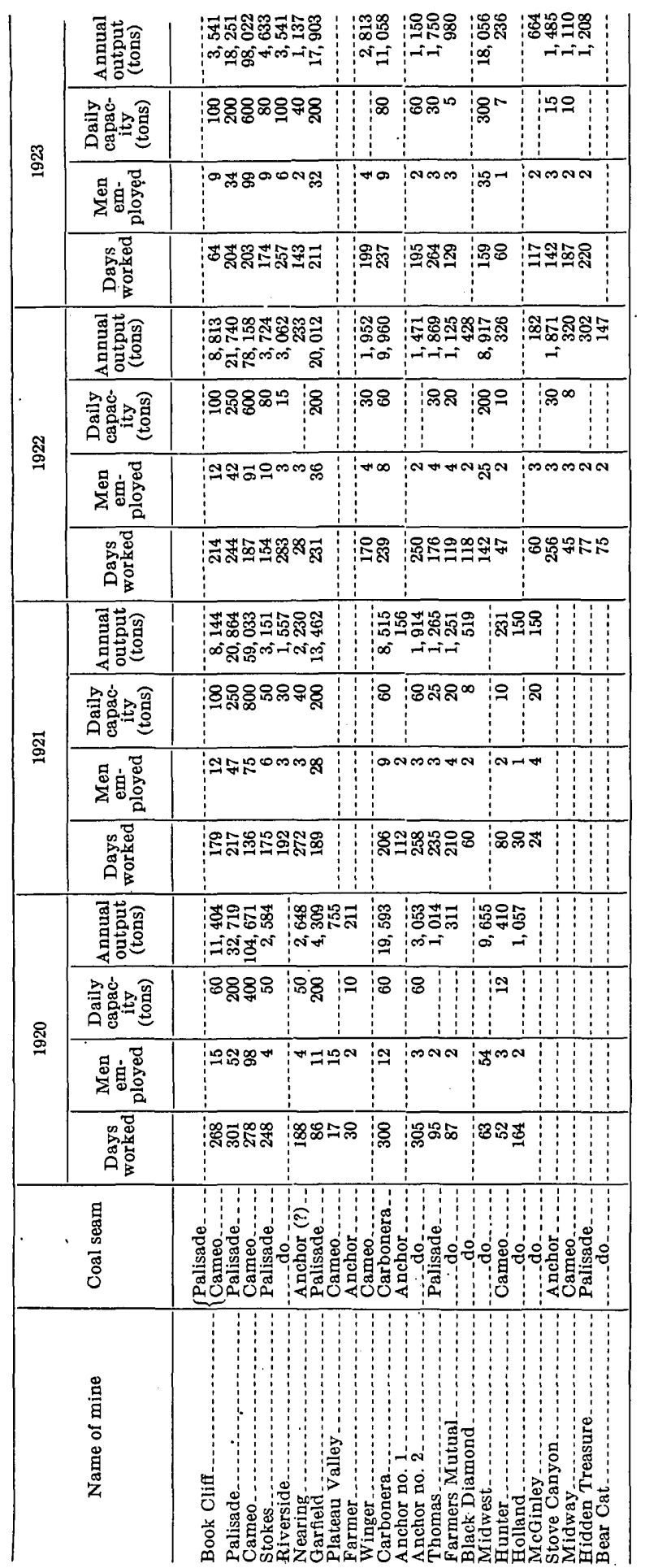




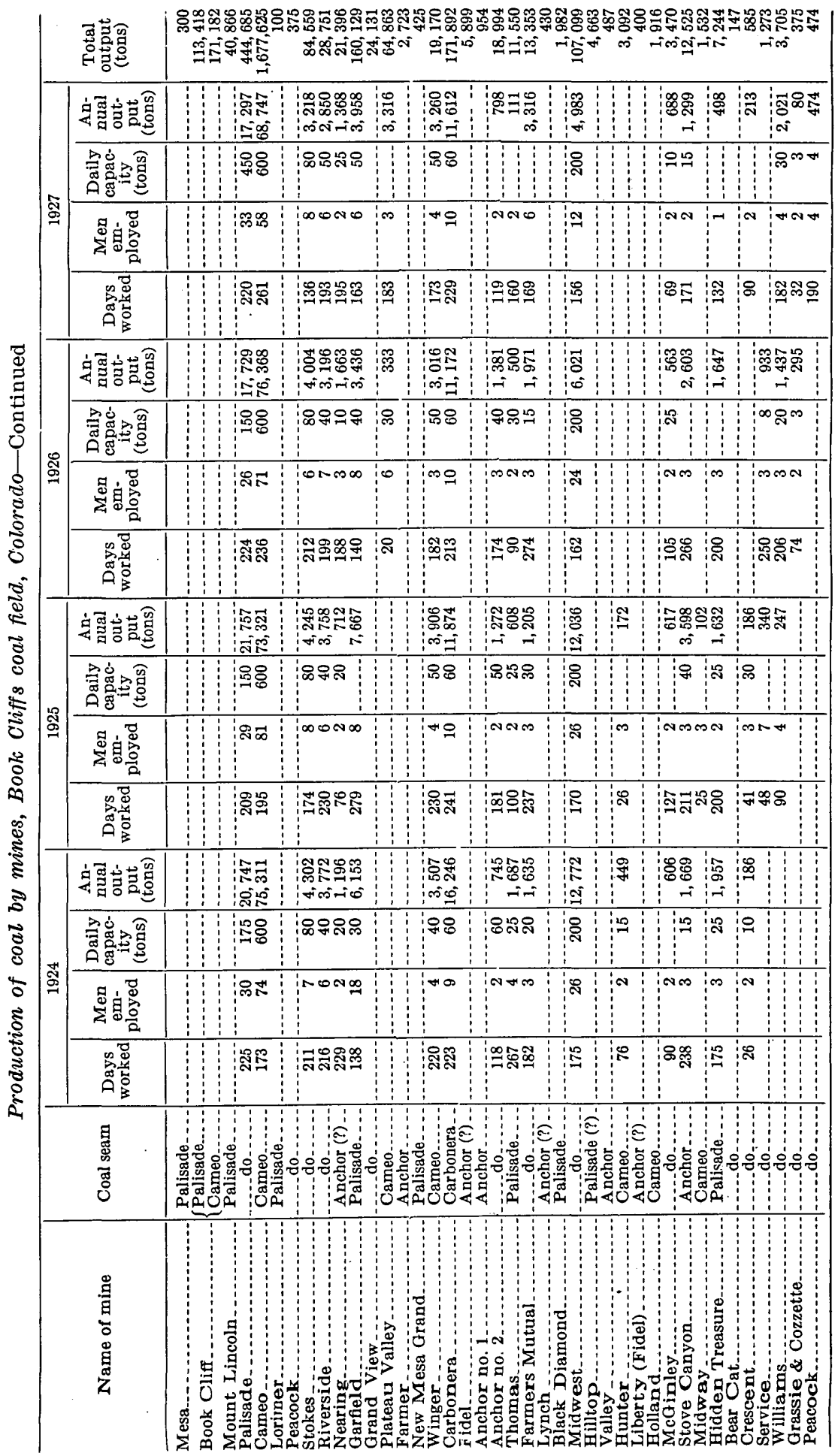


The geographic situation of the Book Cliffs coal field of Colorado with respect to its principal competitive regions west of the Continental Divide is shown in figure 2. The names of the important coal-mining localities are indicated on the map by capital letters. The field is literally surrounded by areas producing coal of equal or higher rank. Its rapid development is especially handicapped by coal fields along the main line of the Denver \& Rio Grande Western Railroad, nearer to the chief markets. The high freight rates and the necessity for long hauls to the east and west seriously reduce the power of the Book Cliffs coal in Colorado to compete with that from more favored fields. Salt Lake City and vicinity are supplied with high-grade bituminous coal from the Castlegate-Sunnyside, Wasatch Plateau, and Book Cliffs coal fields in Utah and from the coal fields of southwestern Wyoming. Denver and eastern Colorado are largely supplied from neighboring fields. In general these coals rank lower than the western coals but are favored because of their cheapness. Keen competition also exists locally. "The coals produced at Newcastle and at Rifle and especially those from the Crested Butte-Anthracite-Somerset region compete directly with those mined at Palisade and Cameo, and the same may be said of those mined at Thompsons, Utah.

In the writer's opinion the future growth of the Book Cliffs field will largely be commensurate with local industrial expansion. The tonnage of coal exported will also gradually increase, and more favorable freight tariffs will give great impetus to mining. While awaiting this change of conditions the area will continue to rank as a leading local field, and its value as a reserve field will continue to increase.

\section{SUGGESTIONS FOR PROSPECTING}

The Book Cliffs coal field has been thoroughly prospected by the coal men of the region. Every favorable, accessible seam near a possible source of demand appears to have been examined; and the grouping of the coal mines into small districts more or less adjacent to the settlements or to transportation is a testimonial to the success achieved. Nevertheless, even in these favored localities there are many abandoned workings whose failure is due to lack of systematic prospecting. The bed worked has suddenly thinned to an unminable thickness, or bone and carbonaceous shale have appeared in such amounts as to make mining profitless. Such conditions cannot always be accurately forecast, but the general areas where they are most likely to occur can be recognized. An effort has been made in this report to picture the irregularities and uncertainties of coal beds in general, and more specifically to point out the localities where conditions are unfavorable for mining at the present time. The 50646-34-8 
information presented in this report must not be accepted as final and complete: it should be regarded merely as the result of a detailed reconnaissance. Much more detailed information should be required by one who contemplates systematically opening and developing a mine; the cover or concealed outcrops should be trenched through, and core drilling may be necessary to ascertain the thickness of coals under heavy cover or behind burned outcrops. The suggestions offered below apply more exclusively to prospecting at some future time, when conditions warrant improved transportation facilities into the cliffs.

Anchor coal.-Further prospecting of the Anchor coal on the east side of Salt Wash Canyon, in secs. 12 and 13, T. 8 S., R. 102 W., and in the mouth of Coal Canyon, in sec. 24, may prove fruitful. A more detailed study of the outcrop in secs. 28 and 34 is also warranted.

Palisade coal zone.-The coals in the Palisade coal zone have been examined in greater detail than those at any other horizon in the field. East of Hunter Canyon the most favorable localities have long been selected. West of the canyon the lenses mentioned in the description of the Palisade zone are all legitimate prospecting ground. In T. 7 S., R. $103 \mathrm{~W}$., the outcrops in the vicinity of the southwest corner of sec. 32 , the west center of sec. 24 , and the center of sec. 33 all merit more detailed study. Two small lenses occur in sec. 28, T. 7 S., R. 104 W. Good seams may occur in the zone in intervening areas, but the preliminary examination indicates that such a possibility is slight.

Cameo coal zone.-The coals of the Cameo coal zone have not received the attention their importance merits. The burned and inaccessible outcrops are responsible for this neglect. In the east end of the field good coal may occur in the Cameo zone near the center of sec. 11 and southeastward in sec. 13, T. 1 N., R. 1 E.; in secs. 35 and 36, T. 10 S., R. 99 W.; and in secs. 3,4 , 5, and 6, T. 11 S., R. $98 \mathrm{~W}$. Extreme care should be taken to avoid areas of bony coal in these localities. In T. 9 S., R. 100 W., the outcrop between Hunter Canyon and the Midway-Farmers mine is extensively burned, but a very careful search might reveal localities where erosion has cut through the clinker. Two benches of coal probably exist along this front. The upper is likely to be the best, the lower bony. Burned outcrops are characteristic of T. 7 S., R. 102 W., but entries into good coal seams may be made from McLane Canyon, from Mungers Gulch and tributaries, and from Stove Canyon, in the northwestern part of T. 8 S., R. 102 W. The outcrop between Hunter Canyon and Salt Wash is so thoroughly concealed that no information exists concerning the coals behind the clinker. In the western portion of the field favorable areas for prospecting occur in 
the vicinity of South Canyon, in the northeast corner of T. 7 S., R. $103 \mathrm{~W}$. In this locality, however, the Cameo coals are likely to prove thinner and less inviting than the Carbonera seams. The southwest corner of T. 7 S., R. 103 W., and the northeast corner of T. 8 S., R. 103 W., and adjacent portions of T. 7 S., R. 104 W., also contain coals concerning which there is need for more detailed information.

Carbonera coal zone.-The Carbonera zone deserves more thorough prospecting over secs. $18,19,31$, and 32 , T. 6 S., R. $103 \mathrm{~W}$; secs. 23-27 and 34-36, T. 6 S., R. 104 W.; secs. 5-8, 17, and 18, T. 7 S., R. 103 W.; and secs. 1-3 and 11-14, T. 7 S., R. 104 W. In addition, prospecting behind the burned outcrops in Salt Wash Canyon and tributaries, in sec. 1, T. 8 S., R. 102 W., and in Coal Canyon, in sec. 18, T. 8 S., R. 101 W., should reveal good beds of coal.

\section{TOWNSHIP DESCRIPTIONS}

The following detailed descriptions of coal beds by townships are arranged to cover the outcropping beds from east to west in the Book Cliffs field. They supplement the more general descriptions and in part are explanatory of the coal sections shown in the plates. In order that the information concerning the Book Cliffs field may be as complete as possible, some of the coal descriptions and sections given by Richardson ${ }^{81}$ are incorporated. New correlations have been assigned to some of the sections examined by him. The field was mapped as a unit except for Tps. 10 and 11 S., R. 98 W., at the east end. The data concerning these townships have been compiled from information supplied by Richardson and by W. W. Boyer, of the Geological Survey.

\section{T. 11 S., R. 98 W.}

A fractional township (T. 11 S., R. 98 W.) was mapped by W. W. Boyer during May and June 1924. The part north and west of the Colorado River properly belongs to the Book Cliffs coal field; that to the east falls within the boundaries of the Grand Mesa field. The part within the Book Cliffs field east to the Garfield mine was remapped in 1926. Two coals crop out in this township-the Palisade coal, just above the Sego sandstone, which caps the Mancos shale, and the Cameo coal, which crops out north of the Palisade coal at the toe of the Rollins sandstone dip slope. The Cameo coal cannot be seen from the front of the cliffs. Good natural outcrops exist on both beds, and there has been practically no burning. Because of the nearness of the railroad this area is the principal shipping point of the Book Cliffs coal field in Colorado. West of the

${ }^{81}$ Richardson, G. B., Reconnaissance of the Book Cliffs coal field, between Grand River, Colo., and Sunnyside, Utah : U.S. Geol. Survey Bull. 371, 1909. 
river the largest mines are the Garfield, Palisade, and Riverside. East of the river the principal workings are the Midwest, Stokes, and Winger. All of these except the Winger are on the Palisade coal.

\section{PALISADE COAL}

Four sections of the Palisade coal were obtained. Those at localities 111 and 112, in sec. 6, were measured on the outcrop by the writer. The two sections from the Garfield mine were kindly furnished by William Liddle, lessee; section $\mathbf{A}$ is from the western part of the mine (which was operating in June 1926), and section B is from the eastern or worked-out part. These sections are given on plate 15. Three sections were measured by Boyer-one at an unnamed locality at the Garfield mine, another at the Riverside mine, and the third at an abandoned prospect about 1,600 feet south of the Riverside mine. Richardson also measured sections of coal at the Riverside, Palisade, and Garfield mines. The sections measured by Boyer and Richardson are given below:

Sections of Palisade coal

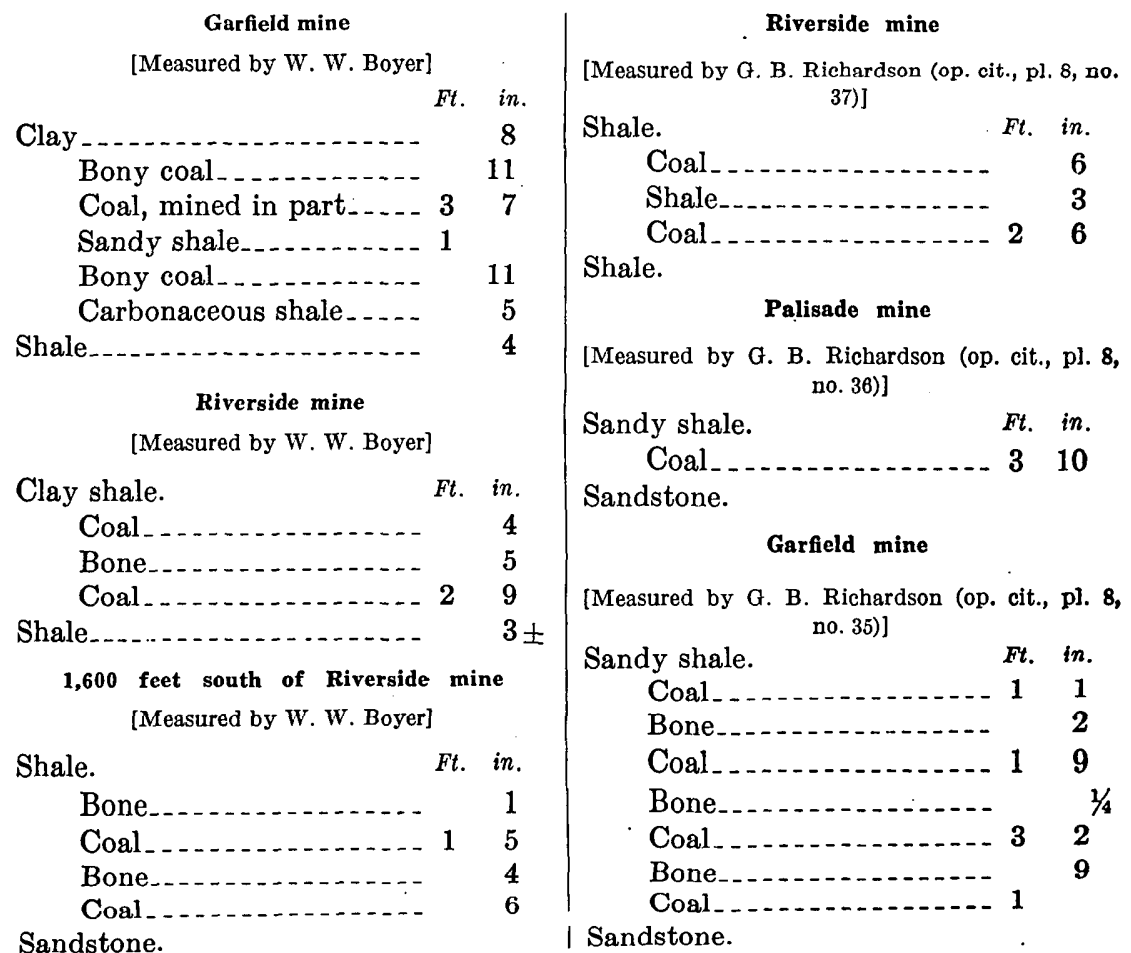


The Palisade coal crops out at water level near the mouth of Hogback Canyon of the Colorado River, about 11/2 miles above Palisade, and passes under the stream a quarter of a mile north of the Riverside mine.

\section{CAMEO COAL}

Few sections of the Cameo coal are available. Those measured by Boyer and Richardson are given below:

\section{Sections of Cameo coal in T. 11 S., R. 98 W.}

On outerop in northeast corner of sec. 3

[Measured by W. W. Boyer]

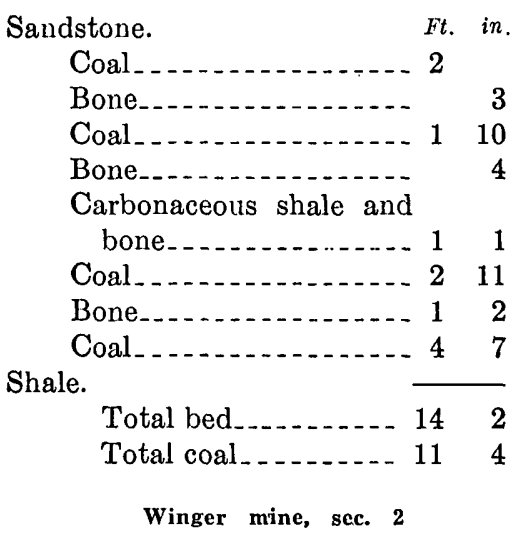

[Basal portion, measured by W. W. Boyer]

Shale.

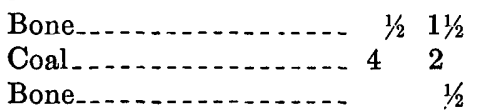

\section{West of Grand River bridge}

[Measured by G. B. Richardson (op. cit., p. 30)] Ft. in.

Coal_................... 24

Bone................... $51 / 2$

Coal_................. 110

Bone.................. 8

Coal__.......... 28

Prospect north of Riverside mine

[Measured by G. B. Richardson (op. cit., pl. 8, no. 24)]

Shale. Ft. in.

Coal_............... 43

Bone_.............. $5 \frac{1}{2}$

Coal._............ 10

Sandstone.

\section{Prospect north of Palisade}

[Measured by G. B. Richardson (op. cit., p. 30)] Fi. in.

Coal_................... 36

Bone................ 1

Coal_....... 25

\section{T. 11 S., R. $99 \mathrm{~W}$.}

Only the Palisade coal occurs in T. 11 S., R. 99 W. The stratigraphic interval to the Cameo coal, which crops out in secs. 35 and 36, T. 10 S., R. 99 W., is about 450 feet.

The Palisade coal is well exposed along the face of the Book Cliffs, and there is no burning along the outcrop. Six coal sections were obtained. (See pl. 16.) Those at localities 109 and 110 were dug out on the outcrop. Two measurements were made at the Gearhart prospect-one on the outcrop at the entry and the other at the working face (June 27, 1926).

In this vicinity the Palisade coal is of low bituminous rank. It ranges in thickness from 3 feet 2 inches to 5 feet 5 inches. The thick- 
ness increases to the east, owing to the disappearance of the shale partings. No bedded impurities other than these partings were observed. There are from one to three partings, but only one of these is thick and persistent. This one is a lenticular bed of carbonaceous shale that occurs from 1 to 3 feet above the floor; its thickness diminishes toward the east from 3 feet 9 inches to 11 inches. In the Gearhart prospect the effort to mine out this parting and the coal below it was soon abandoned. The sample of coal for analysis cut here was taken from the upper bench. Irregularities such as rolls and horsebacks were not observed.

Throughout the area the roof consists of gray to brown carbonaceous shale, which ranges in thickness from 11 feet at locality 109 to 2 feet at the Garfield mine, farther east, where it is bony. Where the shale roof is thickest its lower part may contain thin lenses of coal, as at the Gearhart prospect. This shale is overlain by 5 or 6 feet of soft medium-grained light-gray to buff sandstone containing thin layers of light-gray clay shale. This in turn is overlain by more shale. Such a roof will stand over small rooms and entries with very little timber support.

The floor of the bed is the top of the massive Sego sandstone. It is usually covered by a thin layer of carbonaceous shale or bony coal, but no effort is made to remove this layer, as there is no tendency to buckle or heave.

The cover on the part of the Palisade bed that underlies the Rollins sandstone dip slope is fairly uniform in thickness and ranges from 300 to 500 feet.

\section{T. 10 'S., R. 98 W.}

The eastern limit of the Book Cliffs coal field in Colorado is in T. 10 S., R. 98 W. The Cameo coal crops out at river level at the town of Cameo, on the Denver \& Rio Grande Western Railroad. The Palisade coal does not crop out in this township, as it lies about 450 feet below the Cameo zone. The area of outcrop of the Cameo coal lies within secs. 23,33 , and 34 . The following description of this bed is taken from Richardson: ${ }^{82}$

In the Cameo mine the roof is a good, firm sandy shale, and the floor, where the full thickness of coal is worked, is reported to be sandstone, but usually the total thickness of the coal is not removed. The coal has the reputation for being dirty, a condition which is due to the partings it contains. The following measurements were made in the mine at the localities indicated:

${ }^{\text {g2 }}$ Richardson, G. B., op. cit., p. 29. 
Sections of Cameo coal in Cameo mine

[Measured by G. B. Richardson (op. cit., p. 29)]

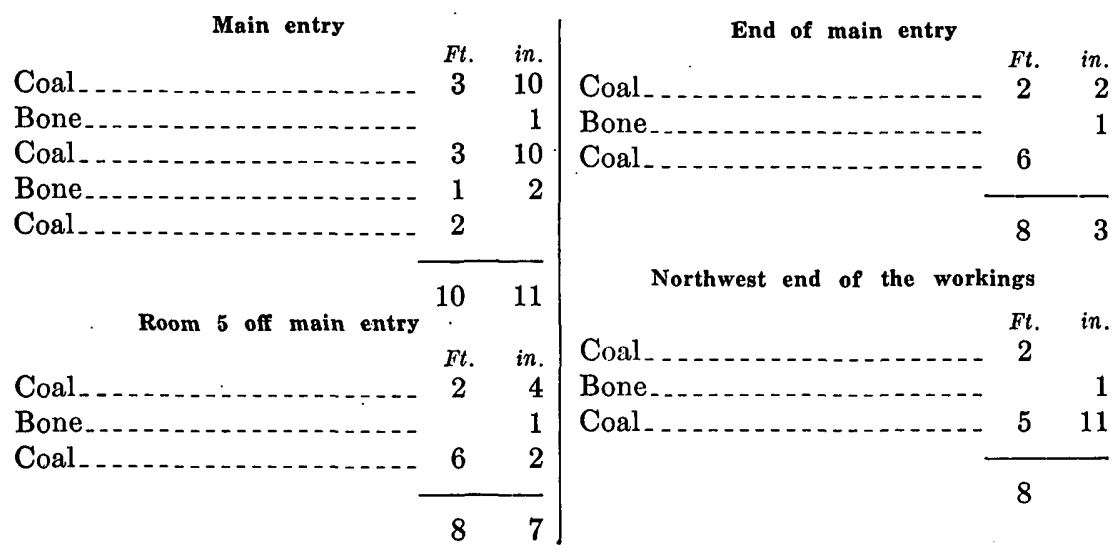

T. 10 S., R. 99 W.

Two coal beds occur in T. 10 S., R. 99 W. The Palisade coal zone occupies about 30 feet immediately above the Sego sandstone. From 450 to 470 feet above it is the Cameo, which overlies the Rollins sandstone.

\section{PALISADE COAL}

The best outcrops of the Palisade coal in this township are in secs. 6 and 7 , but the line of outcrop also passes through the east end of sec. 18 and the southwestern part of sec. 34. In most outcrops the coal is well exposed, but.in some it is obscured by talus. There is little or no burning along the outcrop, except on the landslide block in sec. 7.

The Palisade coal consists of two seams, each containing one or more partings of bone or carbonaceous shale, separated by 25 to 30 feet of carbonaceous shale and sandstone containing thinner coals. The workable coal is in the lower seam.

The coal is under thick cover. The maximum in the northwestern part of the township probably does not exceed 1,500 feet and is attained about half a mile northeast of the outcrop. In the southeastern part it is probably about the same. In the northeast corner of the township the cover thickens and where not removed by erosion it is probably as much as 2,000 feet.

The roof of the lower seam consists of carbonaceous shale or "draw slate", which ranges in thickness from 8 inches to 3 feet. This is overlain by thin-bedded sandstone and some shale. These in turn are overlain by the thinner upper seam. At the Williams mine the roof stands well. The floor of the lower seam consists of 6 to 12 inches of carbonaceous shale resting upon the top of the massive Sego sandstone. 
The Williams mine (pl. 14, $A$ ) is the largest opening on this coal. A prospect opening has been made about 500 feet southwest of the Book Cliff mine, but no coal has been taken out. The old Book Cliff mine, in the NW1/4 sec. 3, T. 1 N., R. 1 E., was opened in the Palisade coal, but conditions were so unfavorable that the workings were soon abandoned. Further prospecting was then done on the west side of the reentrant near locality 103.

Three detailed sections of the Palisade coal were measured by the writer-one at the Williams mine, the other two at localities 102 and 103. (See pl. 16.). The nature of the coal at these localities is essentially the same as at locality 108, T. 1 N., R. 1 E., and locality 109, T. 11 S., R. 99 W. Sections of the coal were measured by Richardson at old workings on the east side of the spur east of the Williams mine, which were not visited by the writer.

Section of Palisade coal at old Keystone or Steele mine, in north-central part of sec. , T. 10 S., R. 99 W.

[Measured by G. B. Richardson (op. cit., pl. 8, no. 30)]

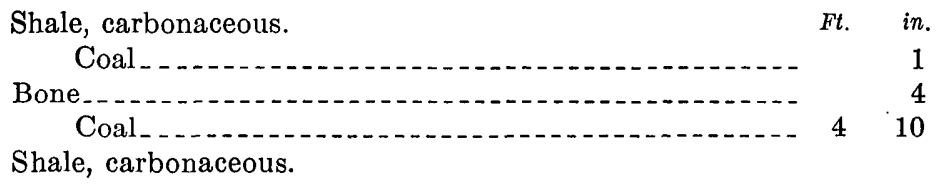

Section of Palisade coal exposed about a quarter of a mile west of Book Cliff mine

[Near locality 103. Measured by G. B. Richardson (op. cit., p. 28 and pl. 8, no. 31)]

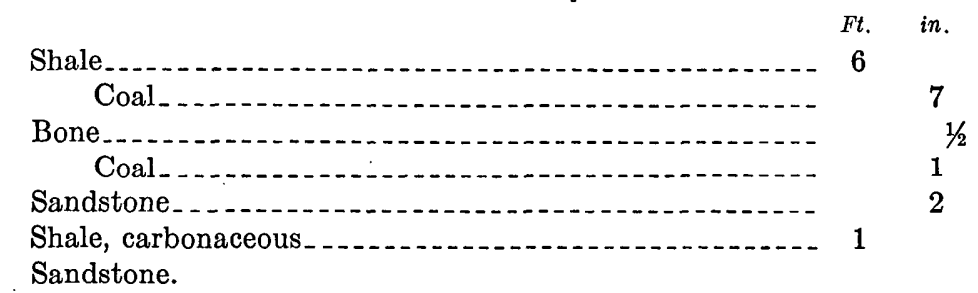

Section of Palisade coal exposed near portal of old Book Cliff mine

[Measured by G. B. Richardson (op. cit., p. 27)]

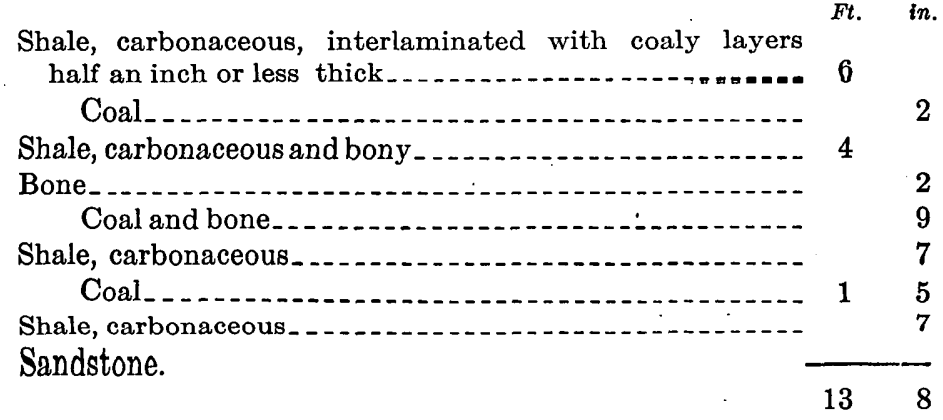




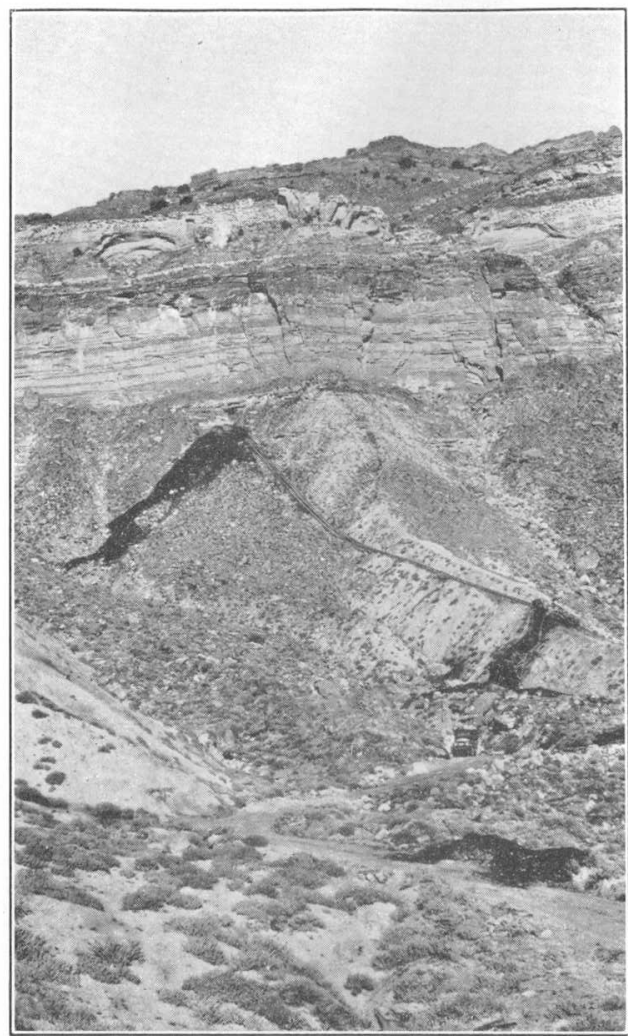

$A$, SURFACE PLANT AT WILLIAMS MINE, IN NORTHWEST CORNER OF SEC. 7, T. 10 S., R. 99 W.

The coal worked is the lower bench of the Palisade. Coal is moved from mine portal to tipple on gravity plane. Typical of many small mines. The massive Rollin sandstone appears at the top of the vertical cliff.

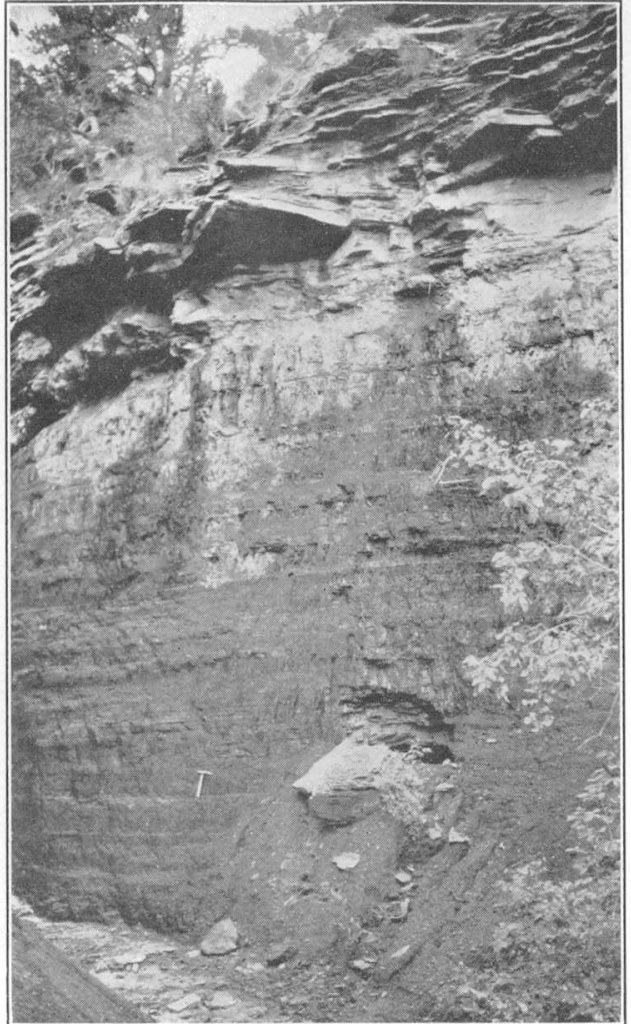

$B$, OUTCROP OF THE CAMEO COAL IN MCLANE CANYON, IN CENTER OF SEC. 21, T. 7 S., R. 102 W. This is the best natural exposure, and the thickest seam of total thickness of the bed is 23 feet. 

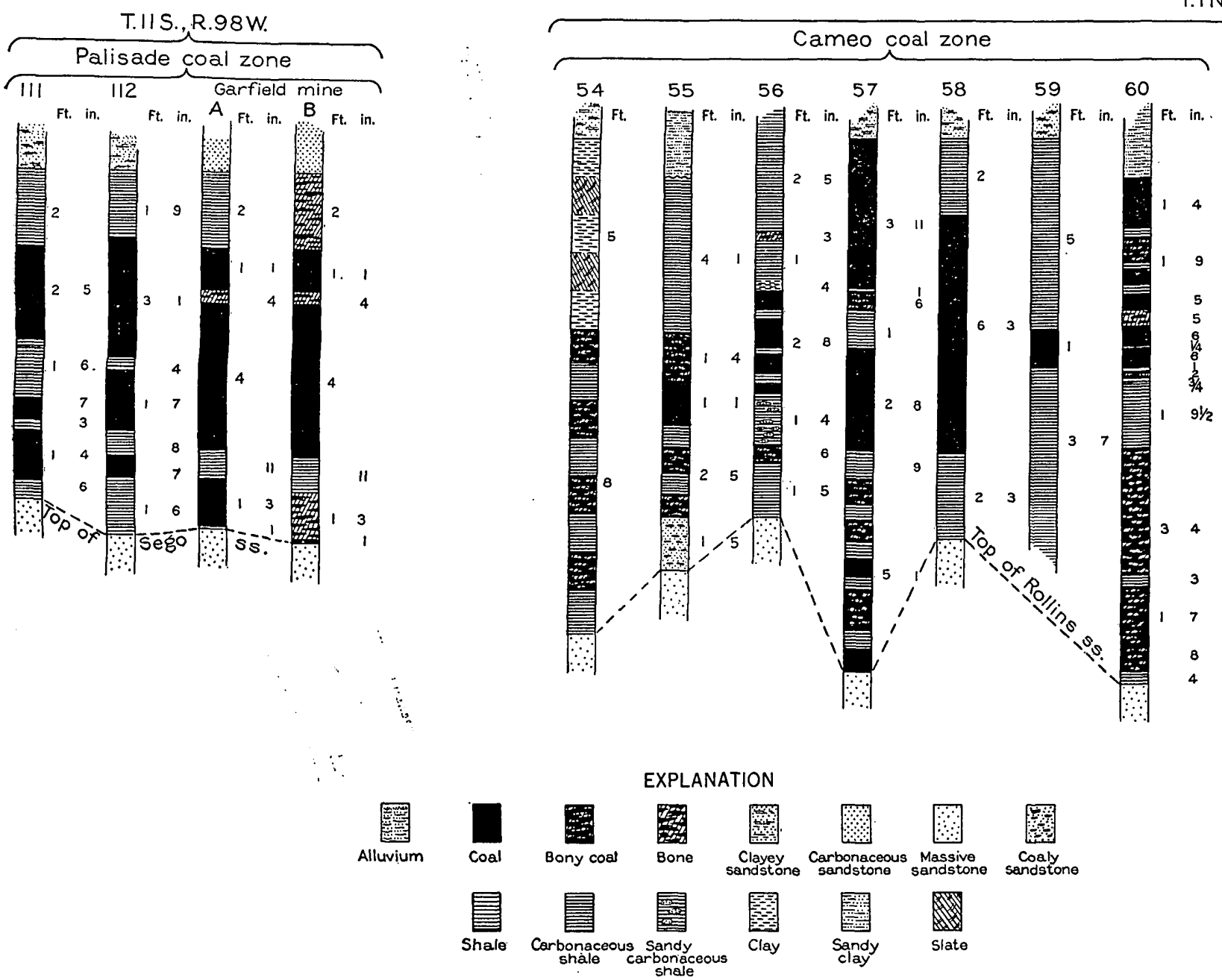

SECTIONS OF PRINCIPAL COALS EXPOSED IN T. 11 S., R. 98 W., AND T. 1 N. .R. 1 E.

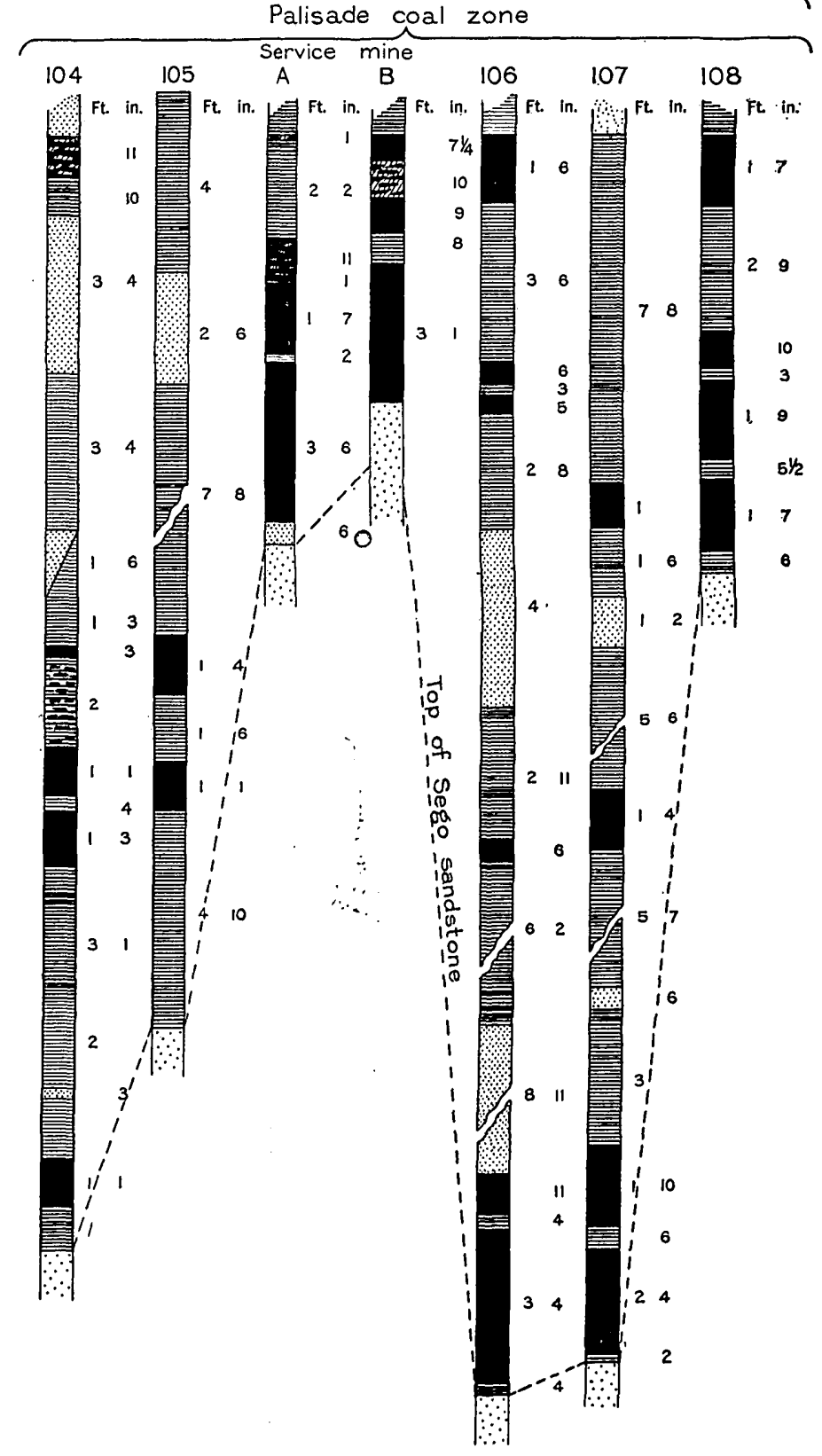



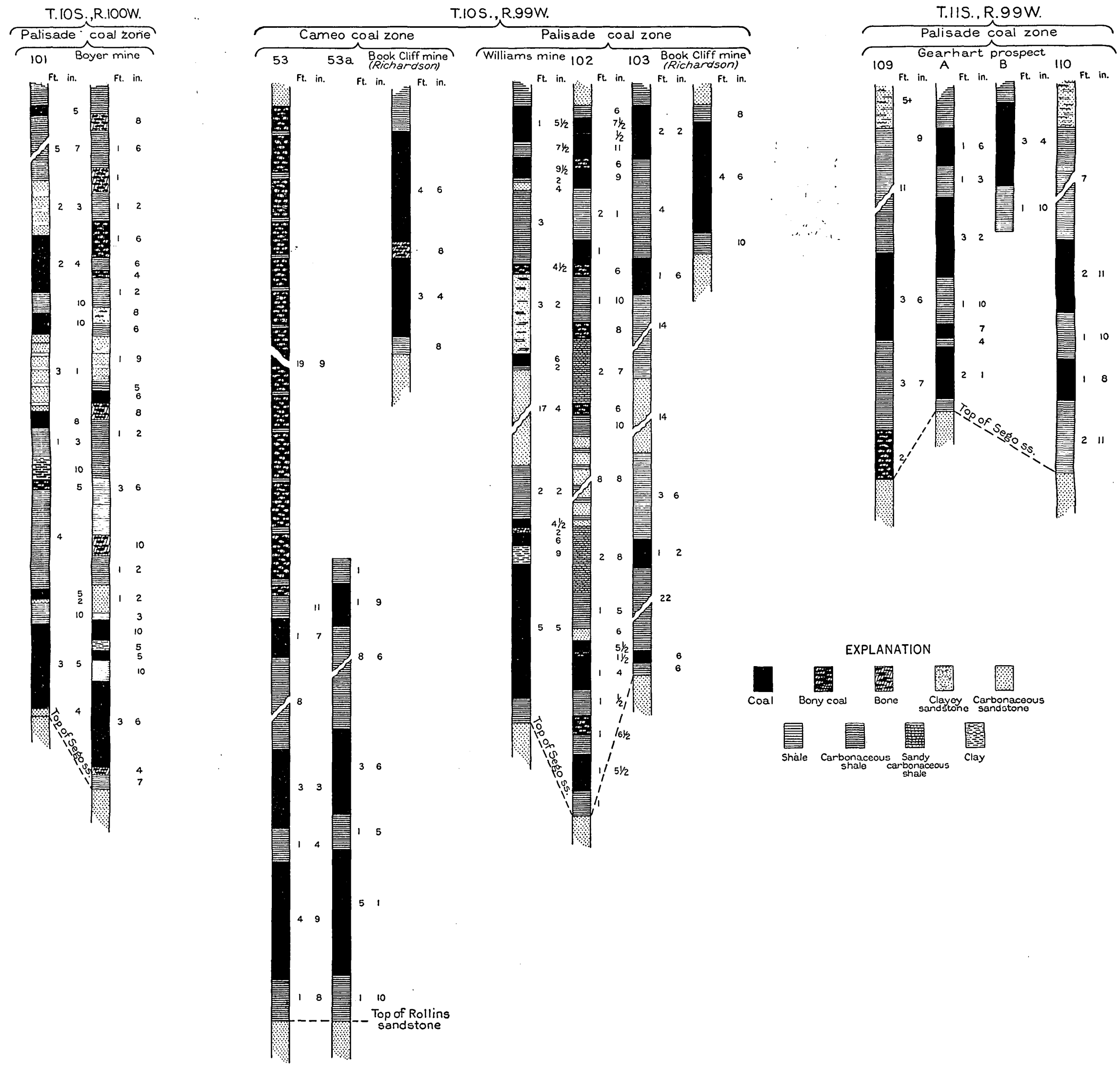

SECTIONS OF PRINCIPAL COALS EXPOSED IN TPS. 10 AND 11 S., R. 99 W., AND T. 10 S., R. 100 W. 
From a point about midway between the Williams mine and locality 102 along the outcrop to a point about 2 miles south of the Book Cliff mine the character of the zone is decidedly irregular. Over the greater part of the area only thin, unworkable coals are exposed, and these exhibit great variations in thickness. In both the upper and lower seams the coal may be entirely replaced by carbonaceous shale. Only the lower seam has been prospected, and after much fruitless work hope of developing a workable property was abandoned. Efforts were then directed to prospecting the Cameo bed.

\section{CAMEO CoAL}

The Cameo coal crops out in secs. $6,7,8,34,35$, and 36 . In secs. 34 to 36 small outliers of coal, usually well burned, lie on the dip slope of the lower cuesta. The main Cameo outcrop lies at the base of the escarpment of the higher cuesta. Almost throughout its length it is either covered with talus or burned, so that no good exposures exist. The bed probably has the same character as in T. 1 N., R. 1 E. In secs. 6 and 7 the Cameo coal is inaccessible on the high cliffs, and the outcrop is burned over much of the area.

The cover on the Cameo coal increases rapidly from the outcrop toward the northeast to 1,000 or 1,100 feet in secs. $6,7,8,25,26,35$, and 36, and to an estimated maximum of 1,500 feet in the northeast corner of the township. Locally this may be reduced by erosion.

The roof consists of a sandstone ledge about 5 feet thick, and the floor is the massive white Rollins sandstone. The workable coals are in the lower part of the seam, and their immediate roof is carbonaceous shale.

The Cameo coal is characterized by the thickness of the seam, its dirtiness (the relatively large amounts of carbonaceous shale, bone, and high-ash coal), and the presence of such irregularities as sandstone "dikes." A faulted sandstone dike at locality 53a is described on page 85 .

The Book Cliff mine is the first opening into the Cameo coal west of the Mount Lincoln mine, near Cameo. The site of the mine was largely determined by the presence of a spring. (See p. 17.) The present mine was opened in 1903. Previously a narrow-gage railway had been built out from Grand Junction, and a camp constructed at the foot of the cliffs in the development of the old Book Cliff mine. The portal is about 800 feet northeast of the terminus of the railroad and is situated just above the Palisade coal. From it a rock tunnel has been driven 750 feet northeast to the coal. In spite of the rather large workings, no great amount of coal was mined. Richardson reports that 5,000 tons was taken out in 1905 . The property has changed hands several times and in 1926 was in the hands of receivers. In 1923 the mine caught fire. Unsuccessful attempts were 
reported to have been made to wall off the fire. The workings were abandoned, and on June 23, 1924, the portal of the mine was sealed.

The two sections of the Cameo coal measured by the writer at localities 53 and 53a show 9 feet and 8 feet 7 inches, respectively, of rather dirty bituminous coal. A section of the Cameo coal in the Book Cliff mine was supplied by W. Liddle, of Palisade, Colo., who reports that at one place in the mine the partings disappear and the workable coal thickens there to about 14 feet.

Section of Cameo coal in Book Cliff mine

[Measured by W. Liddle]

Bone and dark-colored carbonaceous shale (blackjack). Ft. in.

Coal . . . . . . .

Carbonaceous shale

Coal

Carbonaceous shale..... 3

Coal

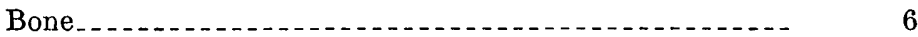

Sandstone, top of Rollins.

Other sections are as follows:

Section of Cameo coal at Book Cliff mine

[Measured by G. B. Richardson (op. cit., pl. 8, no. 20)]

Shale, carbonaceous.
Coal
Bone

Shale, carbonaceous.

Sandstone.

Section of Cameo coal at end of main entry in Book Cliff mine

[Measured by G. B. Richardson (op. cit., p. 30)]

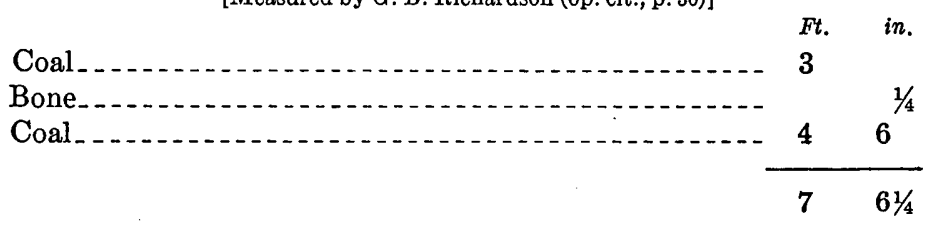

Richardson reports that at the face of the northwest entry 7 feet of coal is exposed, with 14 or 15 inches of bony coal above and below it.

Section of Cameo coal in room of Book Cliff mine

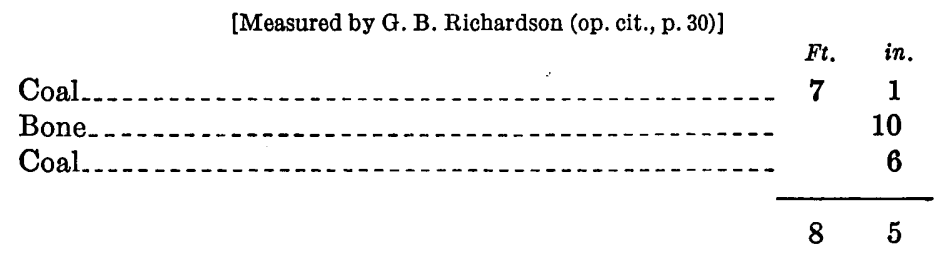


Richardson tentatively correlated a section near the Steele mine with the Cameo coal. Although its stratigraphic position is not: given, the locality leaves little doubt that it is the Cameo.

Section of Cameo coal a quarter of a mile east of Steele mine, near center of NW1/4 sec. 11, T. 10 S., R. 9.9 W.

[Measured by G. B. Richardson (op. cit., pl. 8, no. 19)]

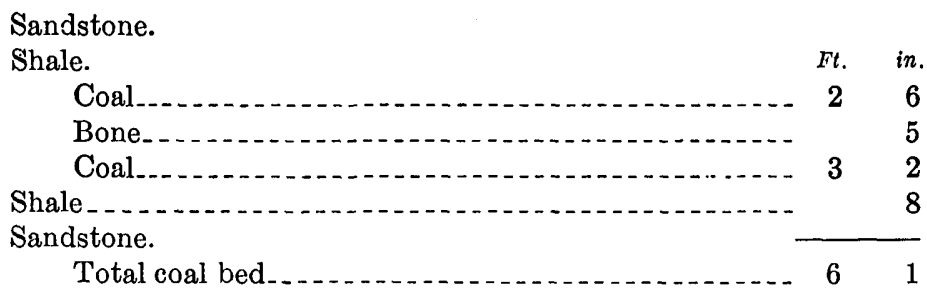

T. 1 N., R. 1 E.

Two workable coals occur in T. 1 N., R. 1 E. Ute principal meridian. (See pl. 15.) They are the Palisade, just above the Sego sandstone, and the Cameo, which overlies the massive Rollins sandstone. The interval from the top of the Sego sandstone to the top of the Rollins sandstone is 440 feet.

\section{PALISADE COAL ZONE}

The outcrop of the Palisade coal zone trends in a northwesterly direction across the northeast quarter of the township. The maximum thickness of the zone is about 35 feet, and the workable coals are in the lower half. Natural exposures are unusually good, but the position of the coal on the cliff makes the exposures inaccessible. Six coal sections were taken along the outcrop at intervals of about a mile, at localities 104, 105, Service mine (A), 106, 107, and 108. Another section was measured at the working face in the Service mine (B). There is no burning along the outcrop.

The Palisade coal, from its outcrop back to the outcrop of the Cameo coal, is under 300 to 500 feet of cover. Beyond the Cameo the cover increases to a maximum of about 1,500 to 1,700 feet in the northeast corner of the township.

The roof of the Palisade zone as a whole is sandstone or sandy shale; but the roof of the workable coal seam is carbonaceous shale or "draw slate" at every place except locality 106, where it is soft sandstone interbedded with shale. It is fairly strong and will stand without timbering over entries and small rooms.

The floor is the massive Sego sandstone. It is firm and strong and will not heave or bulge. Locally it may be somewhat uneven. The sandstone is usually overlain by a thin layer of carbonaceous shale.

The sections in plate 15 clearly show the irregular character of this zone. The zone maintains a fairly constant thickness of 25 to 35 feet and contains four or five beds of coal, of which the thickest and 
only workable one lies near the base of the zone. The other beds do not exceed a thickness of 18 inches. The lower or main Palisade seam has been opened at the old Book Cliff mine (now abandoned), in the NW $1 / 4$ sec. 3, which has also been known as the old Valley mine. Concerning the seam at this locality, Lakes ${ }^{83}$ has said :

A peculiar feature in the seam was the variability in thickness; it changed with some rapidity from 1 foot to 3 or 4 feet in thickness and from this to a knife edge; a considerable distance or area might occur in which there was no coal at all, the zone or line in which the coal should appear being occupied only by a barren shale with an occasional very thin streak of coal. These barren zones, or "horses", as the miners usually call them, were usually accompanied by a change of degree in dip and by gentle undulations or rolls. The first impression was that the coal had been pinched out by rolls * * *, but a closer examination showed this was not the case. In the thin streaks of coal along the horse there was no sign of crushing, as is common in rolling ground. It was evident that the absence of coal was due to its never having been deposited along these barren areas.

The following coal sections give additional details:

Sections of Palisade coal in T. 1 N., R. 1 E.

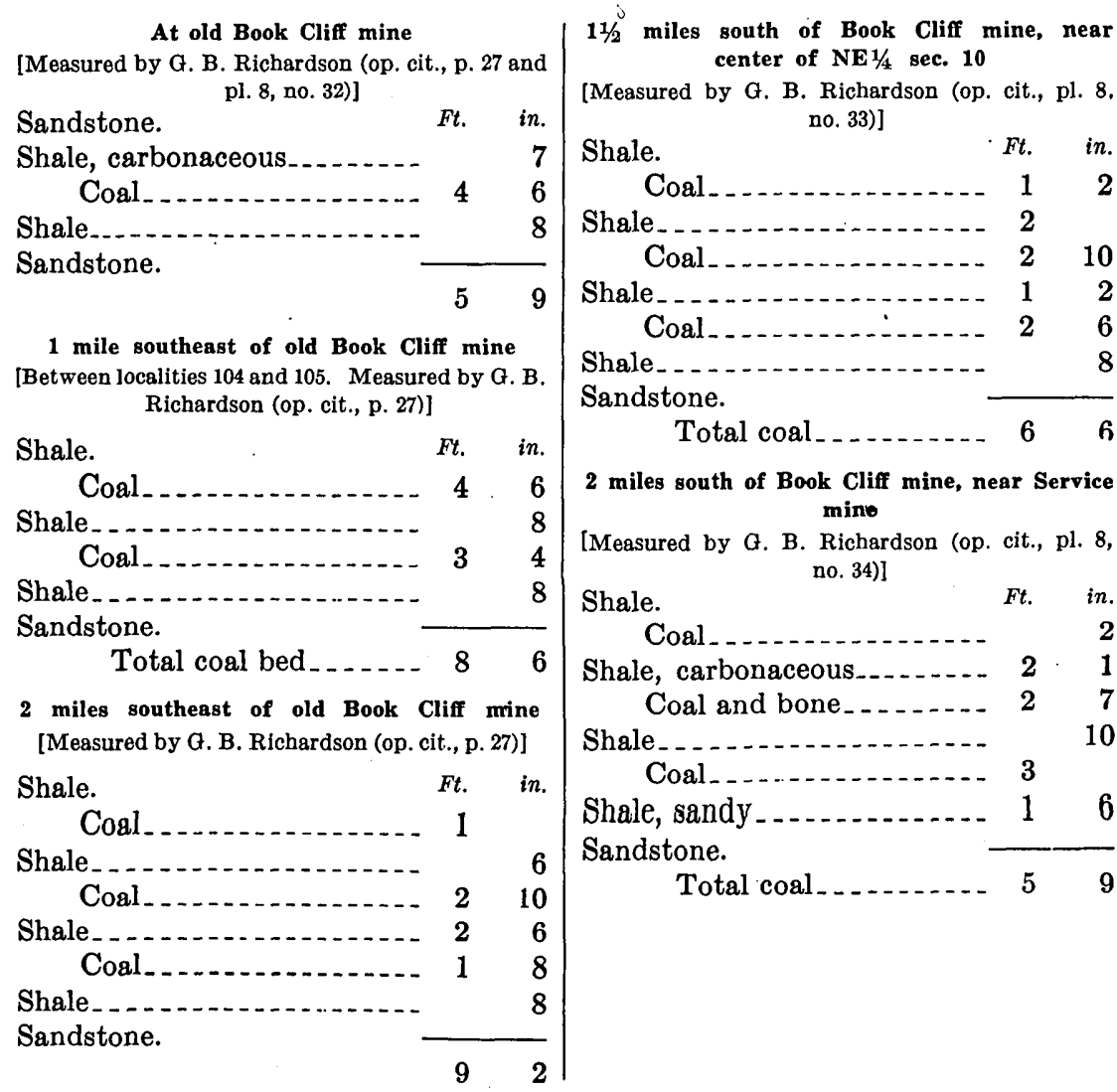

${ }^{8}$ Lakes, Arthur, Book Cliff coal mines : Mines and Minerals, vol. 24, p. 290, January 1904. 
From the Book Cliff mine to the Service mine the Palisade zone is unworkable, most of the coal having been replaced by carbonaceous shale.

The Service mine is the largest recent opening in the coal, but it is now abandoned. Near this mine the coal thickens to a maximum of 7 feet 3 inches, including 1 foot of bone near the top and a thin shale parting 18 inches lower. Section $B$ at the mine was taken at the working face of the main entry, 500 feet from the portal, August 7, 1926. The section indicates the thickening of the partings, which render the upper half of the seam unworkable. The thickening persists to the southeast through localities 106, 107, and 108.

\section{CAMEO COAL}

The Cameo coal crops out just above the lower end of the dip slope on the Rollins sandstone. Resting upon the Rollins sandstone southwest of the main outcrop are many oval or rectangular outliers in which the coal is either burned out or under such shallow cover as to be worthless. In general the exposures are good, especially those along the wash. Elsewhere considerable digging is required to expose the coal. The outcrop is not readily accessible but can be reached by climbing the cliffs at the Book Cliff mine or by passing over them on the trail just west of the Garfield mine. The coal zone was measured and described in detail at localities 54 to 60 . Burning on the main outcrop is extensive only in sec. 11. The cover increases back from the outcrop to a maximum of 1,100 or 1,200 feet in the northeastern part of the township. The roof of the coal zone is a soft, thin-bedded sandstone containing layers of clay shale, but the workable seam is immediately overlain by carbonaceous shale, except in one place where the coal occurs near the top of the zone. The floor of the Cameo coal zone is the massive white Rollins sandstone.

The sections in plate 15 illustrate the great irregularity of the coal, and bear out its reputation for being "dirty." The coal is distributed throughout the zone in thin lentils of varying thickness, which are separated by layers of carbonaceous shale and bone. In some places the total thickness of good coal may be only 1 foot. The great variation is indicated by coal sections at localities 56 and 57 , in sec. 11 , which are only 900 feet apart; and by the coal sections at localities 59 and 60 , in sec. 13, which are 1,000 feet apart.

The most favorable place for prospecting on the outcrop would be from the center of sec. 11 southeastward into the northwest corner of sec. 13. Owing to the position of the outcrop there has been little opportunity for slack to accumulate, and most of the coal exposed is relatively fresh. However, the poor quality of the coal and its inaccessibility do not encourage active prospecting. 


\section{other COAL BEDS}

A zone of carbonaceous shale occurs about 80 feet above the top of the Cameo coal zone. In this zone there may be from two to four thin coals whose total thickness seldom exceeds 30 inches. The maximum noted for any single seam was 15 inches and the minimum 6 inches. This zone is essentially equivalent to that of the Carbonera coals, but a direct correlation by tracing was not made.

\section{T. 10 S., R. 100 W.}

Coal is present in T. 10 S., R. 100 W., only in secs. 1 and 12. There are two coal beds. The Palisade coal crops out on the cliffs about 35 feet above the top of the Mancos shale. The Cameo coal crops out 425 to 450 feet higher.

\section{PALISADE COAL}

The Palisade zone affords the only workable and accessible coal in the township. Though relatively inaccessible along the cliffs, it can easily be reached in the narrow canyons that have been cut into the cliff face. The zone has an average thickness of about 28 feet and consists mostly of carbonaceous shale, with some thin-bedded sandstone and thin seams of coal or bone. 'The main coal bed is near the base, but at locality 101 an upper bed contains good coal.

The coal bed in the lower part of the zone has been opened at a prospect that is now abandoned (locality 101), at the Boyer mine, and at the Black Diamond mine. The Boyer and Black Diamond mines were not operating at the time they were visited (July 1926). These openings show that throughout its extent the lower Palisade seam averages $4 \frac{1}{2}$ feet of good clean coal. The roof is carbonaceous shale or "draw slate," and the floor consists of 4 to 12 inches of carbonaceous shale overlying the top of the Sego sandstone. Two sections, essentially the same, are available.

\section{Section of Palisade coal in Black Diamond mine}

[Measured by G. B. Richardson (op. cit., p. 28)]

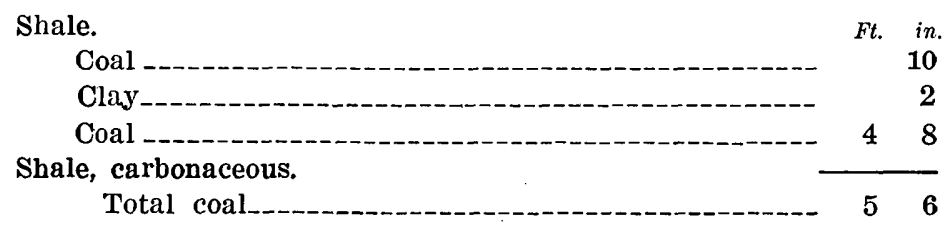

In the other section ${ }^{84}$ the thickness of the main bed of coal is the same, but the thickness of the upper coal and the clay seam are each 1 inch greater. 
The coal goes rapidly under cover, which is about 500 feet thick 500 feet back from the outcrop and attains a maximum of about 1,500 feet at the northeast corner of the township.

\section{CAMEO COAL}

Because of the inaccessible position of the Cameo coal on the cliffs above the Palisade coal and because of the extensive burning of the coal at the outcrop no sections were measured. A section at the Midway Farmers no. 3 mine, northwest of this township, shows that the thick Cameo zone is split by a thick sandstone parting, which is not present at the Book Cliff mine, east of this township. The coal above the parting in this township would probably be unworkable, although the lower bench probably contains minable coal where unburned. The bed is under cover, which increases to more than 1,000 feet toward the northeast.

\section{T. 9 S., R. 100 W.}

Two coal zones occur in T. 9 S., R. 100 W., both in the Mount Garfield formation. The Palisade zone crops out on the cliffs just above the Sego sandstone, and the Cameo occurs 370 to 400 feet higher.

The Palisade coal has been opened at the Farmers no. 2, Farmers Mutual, Grassie \& Cozzette, Thomas, Corcoran, and Hidden Treasure mines. These are all small wagon mines. Only the Hidden Treasure was active at the time it was visited (July-August 1926).

The Cameo coal has been opened at the Midway Farmers no. 3, Holland, Hunter, and McGinley mines. None of these were operating when visited, but the McGinley was making preparations to resume work in the fall of 1926.

\section{Palisade Coal}

The Palisade coal zone consists of a series of overlapping lenses in a thick bed of carbonaceous shale, as in the townships to the southeast. The coal zone contains two major seams, which are separated by carbonaceous shale containing thinner seams of coal, soft sandstone, and shale. The interval between the seams is 35 to 28 feet, decreasing toward the west. Near the middle of the township a lentil with a maximum thickness of 4 feet comes in. This lentil is at the horizon of the upper seam at locality 101, T. $10 \mathrm{~S} ., \mathbf{R}$. $100 \mathrm{~W}$., but probably cannot be directly correlated with it. There is no burning on the Palisade outcrop.

The lower seam is the more persistent and is thickest in the vicinity of the Corcoran mine. Thence it thins regularly to the northwest. It has also been opened at the Thomas mine. A lens 
too thin to work lies 1 to 3 feet above it and is in turn overlapped from the west by another. The roof consists of carbonaceous shale or "draw slate", and the floor consists of carbonaceous shale overlying the Sego sandstone. As the coal thins to the west this lowest layer of carbonaceous shale thickens.

The upper seam is more regular and thicker than the lower, averaging about 3 feet 6 inches. It is persistent through this township but thins both to the east and west. Openings on this seam have been made at the Hidden Treasure, Thomas, Grassie \& Cozzette, and Farmers Mutual mines. The roof is carbonaceous shale except at the last two workings, where it is sandstone. The floor is everywhere a thick bed of carbonaceous shale.

Complete sections of the Palisade coal zone were obtained at localities 96 to 100 and at the Thomas mine and the Grassie \& Cozzette mine; and sections of the workable part of the bed were obtained at the Hidden Treasure, Corcoran, and Farmers Mutual mines. (See pl. 17.) The exposures are good along most of the outcrop, but owing to the inaccessible position of the outcrop on the cliffs, all these sections were taken in the larger reentrants, at intervals of about a mile.

Richardson gives measurements at three places. At the time of his visit to the Corcoran mine (1906) the workings were caved and the full thickness of the seam was not exposed. The Excelsior mine was located in the upper seam of the coal, near the site of the present Thomas mine.

Sections of Palisade coal in T. 9 S., R. $100 \mathrm{~W}$.

At Corcoran mine

[Measured by G. B. Richardson (op. cit.. p. 31 and pl. 8 ; no. 28)]

Shale.

Shale.

Coal

\section{At Excelsior mine}

[Measured by G. B. Richardson (op. cit., p. 31)]

Coal

Interval

Coal

Interval

Coal.

The Palisade coal passes rapidly under thick cover. The maximum along the front of the cliffs probably does not exceed 1,100 feet, but this increases to a maximum of 3,400 feet in the northeast corner of the township.

Near Hidden Treasure mine

[Measured by G. B. Richardson (op. cit., p. 31 and pl. 8, no. 18)]

Sandstone. Ft. in.

Shale.................. 6

Coal_............... 3

Bone........ 4

Coal._.............. 2

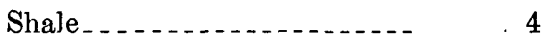

Sandstone.
Total coal bed ....... 544 


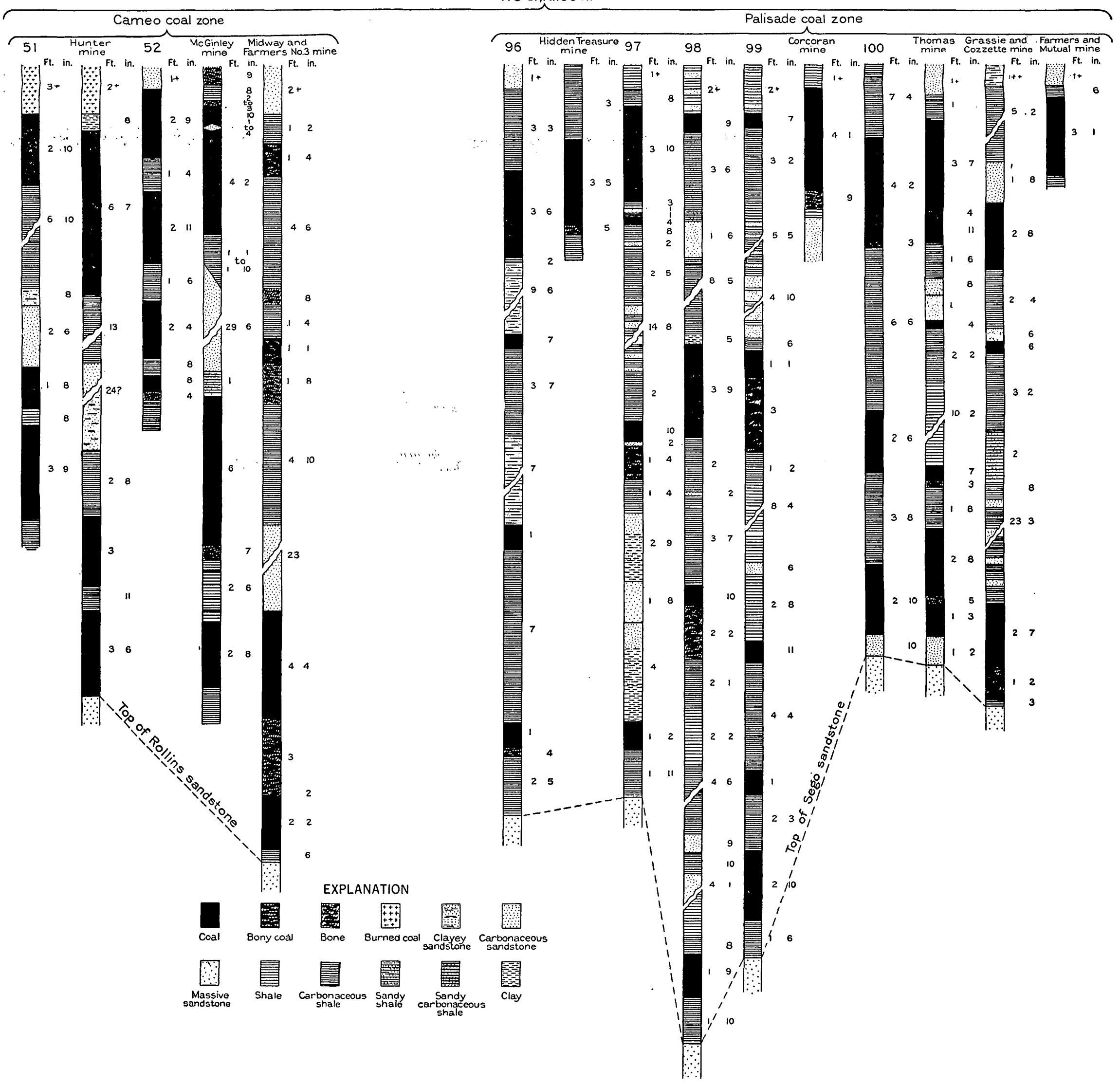

SECTIONS OF.PRINCIPAL COALS EXPOSED IN T. 9 S., R. 100 W. 


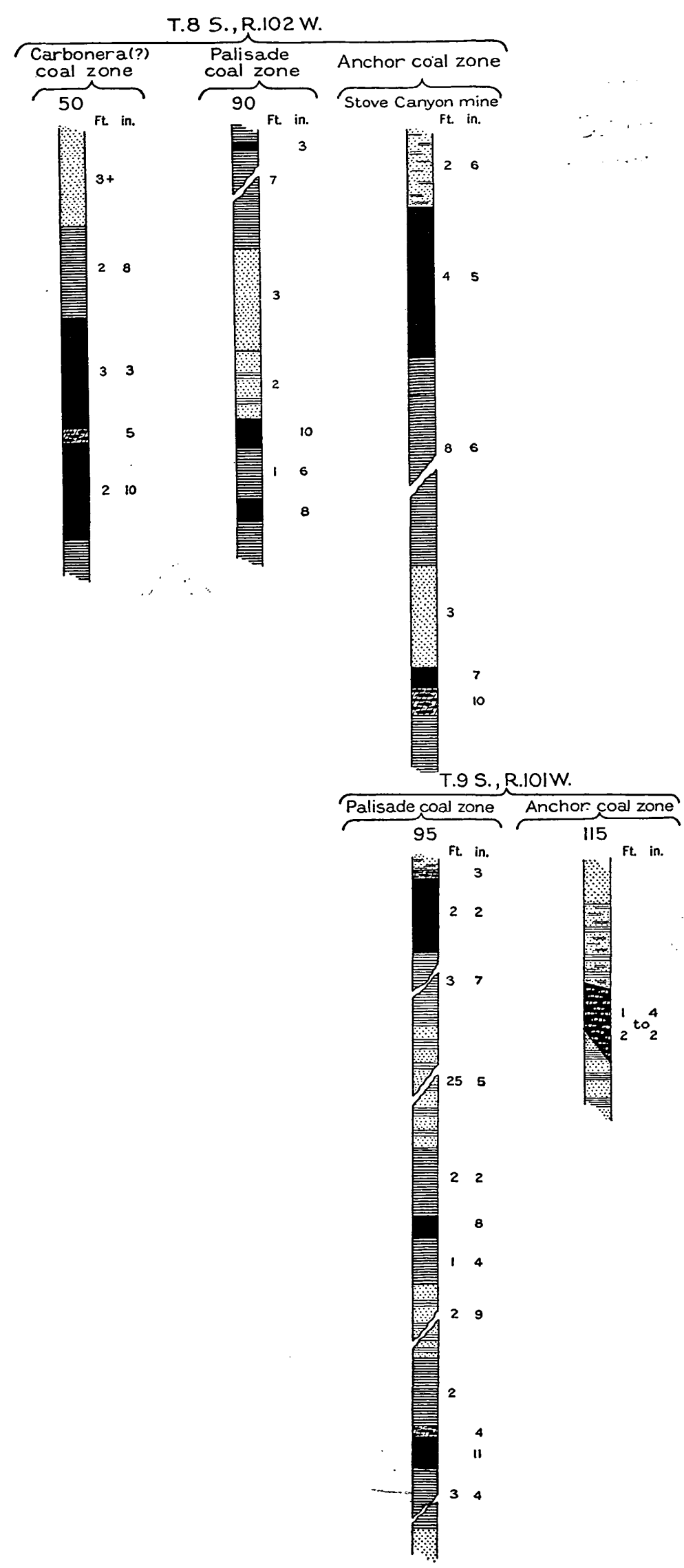

T.8S., R.IOIW.

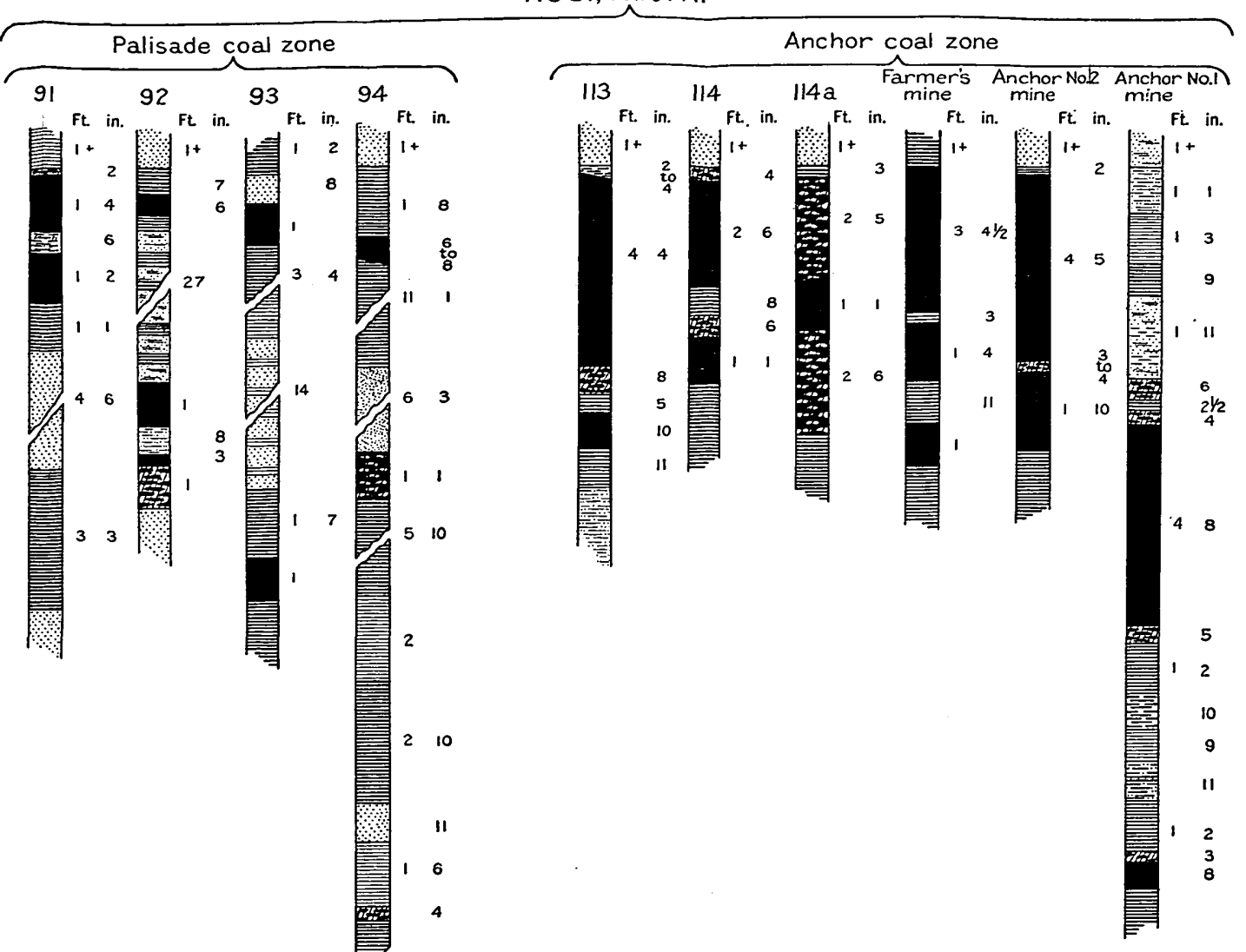

SECTIONS OF PRINCIPAL COAIS EXPOSED IN_TPS. 8 AND 9 S., R. 101 W., AND T. 8 S., R. 102 W. 


\section{CAMEO COAL}

Two partial sections of the Cameo coal were measured in this township. The Hunter, McGinley, and Midway Farmers no. 3 mines all yielded good sections. Incomplete sections were obtained at locality 51 , where the upper seam is in large part burned, and at locality 52 , where the lower seam is under cover. In the remainder of the area, no sections could be obtained, owing either to the high, inaccessible position of the coal along the cliffs or to the general burning of the outcrop.

The conspicuous feature of the Cameo coal in this township is the prominent sandstone parting that divides the bed into two seams. It comes in somewhere southeast of this township.

The upper seam consists of carbonaceous shale and a few thin layers of bone. It has been worked at the McGinley and Hunter mines. The lower seam also contains a bony parting. It has been worked at the Midway Farmers no. 3 mine, but farther west the bony parting changes to sandstone and the seam is not mined, though an opening has been made in it at the McGinley mine.

A sandstone "dike" similar to that near the Book Cliff mine occurs 120 feet in from the portal of the main entry of the McGinley mine. It is 1 foot wide and is composed of fine-grained sandstone. Small calcite veinlets cut across it in several places. The coal on each side is not displaced, and there are no slickensides on the "dike" walls. The strike is $\mathrm{N} .20^{\circ} \mathrm{E}$. It is interesting to note that this strike is the same as that of the "dike" at the Book Cliff mine.

The roof of the seams is either "draw slate" or soft sandstone. The floor is carbonaceous shale, usually underlain by sandstone.

Richardson obtained two sections of the Cameo coal in this township. He states ${ }^{85}$ that at the Bob Cat mine, which was in the vicinity of the present Holland and Midway Farmers no. 3 mines, between 3 feet 8 inches and 4 feet 7 inches of good clean coal was exposed. His section from the Hunter mine follows:

Section of Cameo coal at Hunter mine

[Measured by G. B. Richärdson (op. cit., p. 31 and pl. 8, no. 17)]

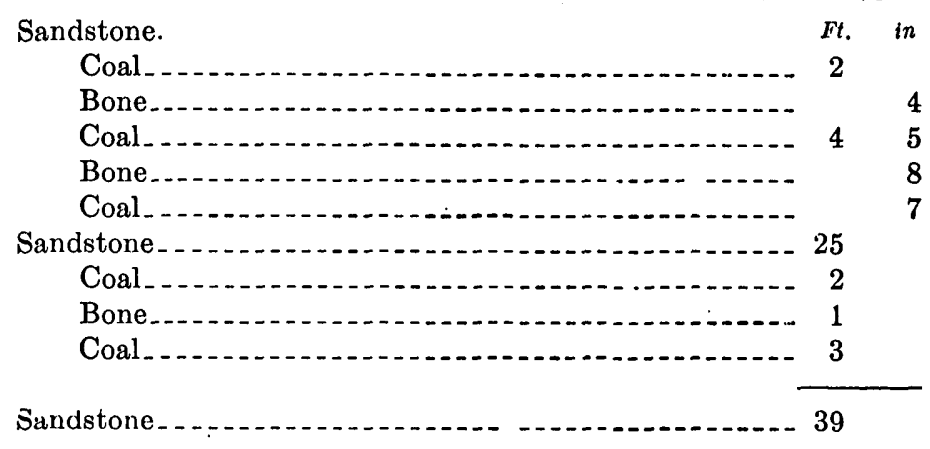

${ }^{85}$ Richardson, G. H., op. cit., p. 30.

$50646-34-9$ 
The cover on the Cameo coal increases rapidly; within a quarter of a mile of the outcrop it is 1,000 feet thick, and in the northeast corner of the township it attains a maximum of more than 3,000 feet.

\section{T. 9 S., R. 101 W.}

Three coals crop out along the cliffs in T. 9 S., R. 101 W.-the Anchor, the Palisade, and the Cameo. All are under thick cover, which increases toward the northeast. The maximum cover on the Anchor coal probably does not exceed 1,200 feet; that on the Cameo, 800 or 900 feet. These coals have not been prospected or developed in this township.

\section{ANCHOR COAL}

The Anchor coal is the lowest that crops out along the cliffs. It is thin and bony in this township but increases in thickness and becomes of better grade toward the northwest. The section at locality 115 was the only one obtained.

\section{Palisade COAL}

The Palisade coal crops out just above the Sego sandstone. It consists of a series of thin overlapping lenses of coal intercalated in carbonaceous shale. At locality 95 three such lenses are present, all in carbonaceous shale, separated by beds of soft sandstone and gray clay shale. None are of workable thickness. The lowest is 11 inches thick and the middle one 8 inches; the upper one is 2 feet 2 inches thick and should be correlated with the seam worked at the Hidden Treasure mine. (See pl. 18.)

\section{CAMEO COAL}

The Cameo coal crops out on the cliffs about 400 feet above the Palisade coal. No sections were obtained, as the outcrop is inaccessible and largely concealed by clinker from the burning of the coal. Back of the clinker this bed may be expected to have the same general nature as in Hunter Canyon.

\section{T. 8 S., R. 101 W.}

Four coal beds crop out in T. 8 S., R. 101 W. The lowest and thickest is the Anchor coal; about 50 feet above this is the Palisade coal; 320 to 360 feet higher is the Cameo coal; and about 60 feet above the Cameo is another bed that is probably the Carbonera.

\section{ANCHOR COAL}

The Anchor coal is stratigraphically the lowest in the Book Cliffs field. It first appears near locality 115, in T. 9 S., R. $101 \mathrm{~W}$., and 
is decidedly irregular in quality and thickness. Near the Anchor no. 1 mine, in sec. 12 , T. 8 S., R. 101 W., the coal becomes thicker and of better grade. Thence westward to the Stove Canyon mine, in sec. 12, T. 8 S., R. 102 W., the bed is fairly uniform. The Anchor no. 1 mine was abandoned about 1920. It was formerly known as the Kiel or Gross mine, and Richardson ${ }^{80}$ reports that from 3 feet to 3 feet 9 inches of coal was exposed in the workings. The principal openings on the seam are the Anchor no. 2 mine, formerly known as the Nugent, and the Farmers (or Valley Commercial), formerly known as the Nearing. Both of these properties are in sec. 29. Richardson ${ }^{87}$ reported 4 feet 3 inches to 4 feet 8 inches of coal at the Nugent and said that at the portal of the Nearing mine, threequarters of a mile to the west, "the coal measures 4 feet to 4 feet 2 inches and contains a variable streak of bone up to 12 inches thick. At the end of the workings the bone disappears and the coal measures 4 feet 7 inches." He also gives a detailed geologic section of the coal-bearing rocks at this locality.

Two coal sections (pl. 18) were measured at localities 114 and 114a, at an abandoned prospect which may be the Mott prospect shown on Richardson's map as locality no. 21. An abandoned prospect in sec. 18 , at locality 113 , is probably the old Lane mine, at which Richardson made the following measurements:

Section of Anchor coal at Lane mine

[Measured by G. B. Richardson (op. cit., p. 33 and pl. 8, no. 14)]

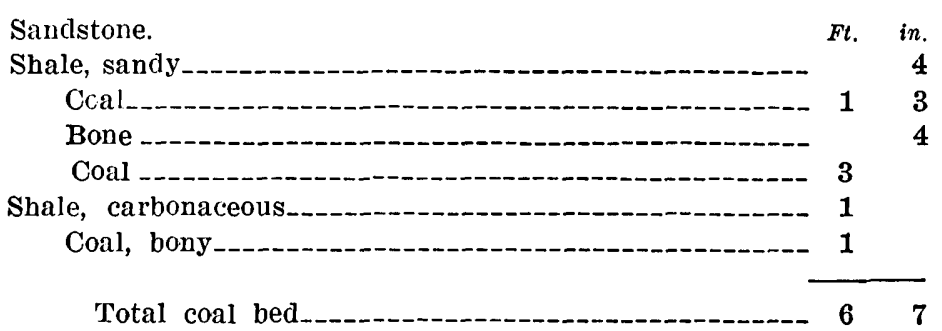

Across the gulch to the south, at the old Johnson mine, he measured the following section on the same bed:

Section of Anchor coal at Johnson mine, in SE1/4 sec. 18, T. 8 S., R. 101 W.

[Measured by G. B. Richardson (op. cit., p. 33)]

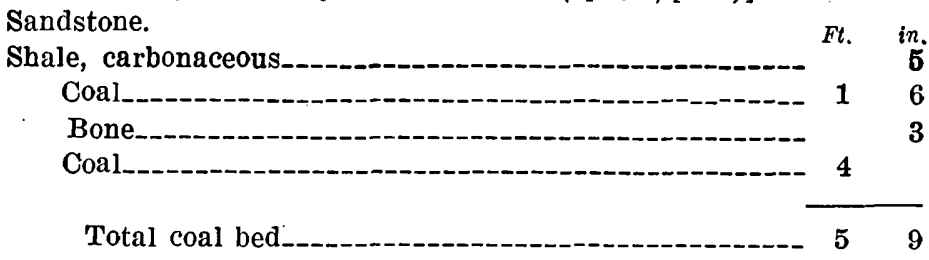

* Richardson, G. B., op. cit., p. 31.

87 Idem, p. 32. 
The thickness of the cover over the Anchor coal increases rapidly back from the outcrop. Within half a mile it becomes as much as 1,200 feet, and along the northern boundary of the township it may be 2,300 feet.

\section{PALISADE COAL}

The Palisade coal crops out along the cliffs just above the Sego sandstone. The coal zone consists of shale and sandstone with thin lenses of coal. Four sections measured at localities 91 to 94 show no single seam thicker than 1 foot 4 inches. Westward from the Hidden Treasure mine, in sec. 5, T. 9 S., R. $100 \mathrm{~W}$., the Palisade zone is of no economic importance at the present time. No openings or prospects in the coal were noted.

\section{CAMEO COAL}

The outcrop of the Cameo coal is burned over practically the whole township. Owing to the burning and to the inaccessible position of the coal on the cliffs, no coal sections were measured. The old mine on the south side of Coal Gulch, near where the coal bed crosses the dry wash, is reported to have been on fire for many years. The maximum cover over the coal is about 1,900 feet in the northern part of the township. No recent prospecting or development work has been done on the Cameo coal in this township.

\section{Carbonera ( ?) COAL}

A mile and a half east of the old Lane mine, at locality 113, in sec. 17, Richardson measured the following section:

Section of Carbonera(?) coal 11/2 miles east of Lane mine

[Measured by G. B. Richardson (op. cit., p. 33)]

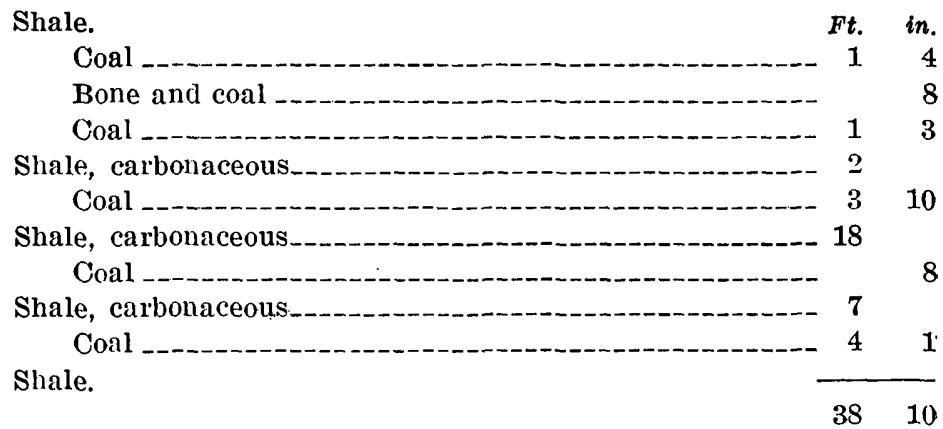

The sections most nearly comparable to this are those of the Carbonera zone in sec. 1 (locality 50) and sec. 2 (locality F), T. 8 S., R. 102 W. There is correspondence between the thickness of the zone as a whole and the position of the coals with respect to the 
partings, as well as some agreement in the thickness of the respective coals. On this basis the coal of the section given above may be tentatively referred to the Carbonera zone, but direct correlation cannot be made because of the burning of the coals downstream from the point where they pass under the canyon floor. If the suggested correlation is correct the center of sec. 17 is the most easterly locality at which the Carbonera coal zone is known.

\section{T. 8 S., R. 102 W.}

Four coal zones crop out in T. 8 S., R. 102 W. The lowest and thickest is the Anchor coal; the Palisade zone is 50 to 70 feet above the Anchor; the Cameo lies about 300 feet above the Palisade; a lens of coal occurs 65 feet above the Cameo, and though it has not been directly correlated with the Carbonera zone by tracing it is referred to that zone on account of its stratigraphic position.

\section{ANCHOR COAL}

Exposures of the Anchor coal are not good in this township. There is some burning along the outcrop in secs. 10, 11, 13, and 24. The Stove Canyon mine, the only opening that has been made in the seam, shows it to be 5 feet 5 inches thick. The roof of the seam in the mine is a soft, thin-bedded shaly sandstone, and the floor is carbonaceous shale. Except in canyon areas the bed is under thick cover, which increases rapidly back from the outcrop. A maximum thickness of probably 1,200 feet is attained in the northern part of the township.

\section{PALISADE COAL}

The Palisade coal crops out in the cliffs just above the Sego sandstone. The exposures are not good, for the outcrops are covered with talus from the overlying beds and are burned at many places. Three measurements were made. (See pl. 18.) At locality 90 , near the point where the bed crosses Salt Wash, three thin seams of coal are present, the thickest measuring 10 inches. Soft sooty black coal 3 feet thick is exposed at locality G, in sec. 10. Near locality J, in sec. 4 , the bed shows burns, but examination of nearby outcrops reveals only bluish-gray to chocolate-colored carbonaceous shale with no coal. A short distance to the northeast the bed is locally unburned, and a 1-foot coal bed of fair quality is exposed. Westward from the Hidden Treasure mine, in sec. 5, T. 9 S., R. 100 W., the Palisade coal is of no economic importance and does not warrant prospecting.

\section{CAMEO COAL}

The Cameo coal lies about 300 feet above the horizon of the Palisade coal. It is burned at the outcrop almost everywhere in this township. Four sections were measured near the point where the 
bed crosses Stove Canyon, and examinations were made at three places along the face of the cliffs.

The bed is heavily burned on each side of the lower part of Stove Canyon, and the first place where a detailed examination can be made is at locality A, 2,100 feet east and 3,300 feet north from the southwest corner of sec. 2 .

Section of Cameo coal at locality A, sec. 2, T. 8 S., R. $102 W$.

\begin{tabular}{|c|c|c|}
\hline ndstone, thin-bedded. & & in. \\
\hline Bituminous coal, clean, bright__. & & \\
\hline Bone and bony coal & & 7 \\
\hline Coal & & $51 / 2$ \\
\hline Shale, carbonaceous & & $1 / 4$ \\
\hline Coal & & $51 / 2$ \\
\hline Shale, carbonaceouss-_- & & $1 / 4$ \\
\hline Coal, bituminous, clean, bright & 2 & 3 \\
\hline${ }^{\circ}$ Bony coal & & 5 \\
\hline Coal, bituminous, clean and bright, weathers rusty & & 7 \\
\hline Shale, carbonaceous & & 1 \\
\hline Coal -1- & & $41 / 4$ \\
\hline Shale, carbonaceous_. & & $\frac{1}{10}-1 / 8$ \\
\hline Coal, bituminous, clean and bright; weathers rusty & 3 & 6 \\
\hline Bony coal-ans & 1 & $11 / 2$ \\
\hline Coal; bituminous, clean and bright_. & & 8 \\
\hline Coal, weathered; base concealed._-_. & & $1+$ \\
\hline
\end{tabular}

The coal has two cleavages; the better one strikes $\mathrm{N}$. $75^{\circ} \mathrm{E}$., and the other is approximately at right angles. The entry follows the direction of the good cleavage for a distance of 20 feet.

The coal is more fully exposed at locality $B, 1,800$ feet east and 3,450 feet north from the southwest corner of sec. 2, where the following section was taken:

Section of Cameo coal at locality B, sec. 2, T. 8 S., R. $102 \mathrm{~W}$.

Shale, carbonaceous, sandy, gray, thin-bedded, and sandstone, thin-bedded.

Coal, bituminous, clean

Ft. in.

Shale, carbonaceous

49

Coal, bituminous

$231 / 2$

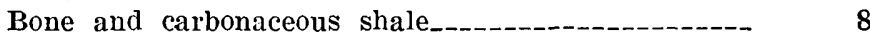

Ooal, bituminous; upper 18 inches has two thin seams ( $1 / 8$ to $1 / 4$ inch) of carbonaceous shale

Bone

39

Bony coal, sandy

Shale, carbonaceous

7

Coal

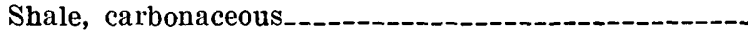

Coal

Shale, carbonaceous, sandy

Sandstone, thin-bedded ( 1 to $1 / 4$ inch), platy, shaly at base 
The same coal bed is exposed at locality C, 1,500 feet east and 3,450 feet north from the southwest corner of sec. 2. Though the upper part is burned, the lower part exhibits coal seams that are only partially exposed at locality B. The base of the Cameo coal closes at this point.

Section of Cameo coal at locality C, sec. 2, T. 8 S., R. $102 \mathrm{~W}$.

\begin{tabular}{|c|c|}
\hline $\begin{array}{l}\text { Clinker. } \\
\text { Coal, bituminous }\end{array}$ & \\
\hline Shale, carbonaceous, & $\mathbf{2}$ \\
\hline Sandstone, thin-bedded & 6 \\
\hline Coal, bituminous, & 3 \\
\hline $\begin{array}{l}\text { Sandstone, gray-white, slightly carbonaceous, massive 10- } \\
\text { inch beds }\end{array}$ & 3 \\
\hline
\end{tabular}

There is an old prospect in Cameo coal at locality D, 1,500 feet east and 3,900 feet north from the southwest corner of sec. 2, where the coal crops out as a vertical wall on the west side of the canyon. The mouth of the entry, which is about 3 feet above the floor of the wash, penetrates the bed for 30 feet and strikes S. $82^{\circ}$. W.

Section of the upper part of the Cameo coal zone at locality $D$, sec. $2, T .8 \mathrm{~S}$, R. $102 W$.

Sandstone, buff, massive, thinly laminated ledges ; strong

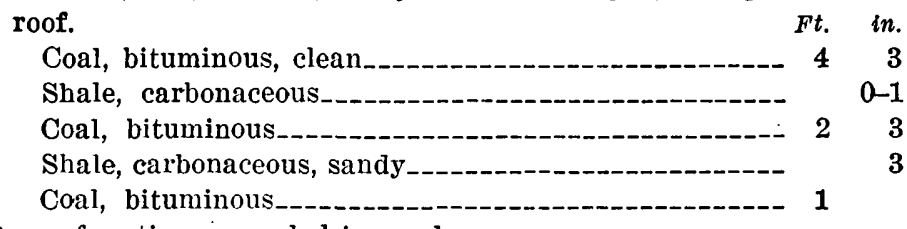

Base of section concealed in creek.

The coal from this prospect is reported to be one of the cleanestburning coals in the region. It is no longer worked because of the difficulty of keeping the road open up the canyon.

At locality $\mathrm{H}$, in sec. 10, the Cameo coal is unburned on the face of a vertical cliff. From a distance of about 1,500 feet the thickness of the coal exposed was estimated to be not less than 6 feet.

At locality I, in sec. 10, a bed of partly burned soft, sooty coal 4 feet 4 inches thick crops out.

At locality $K$, in sec. 4, a locally unburned seam of the Cameo coal is exposed on a vertical wall at the head of a reentrant in the cliffs. Its thickness was estimated to be about 7 feet.

Richardson gives a section of a coal bed that is probably the Cameo from a locality on the outcrop in sec. 11, west of the Stove Canyon mine. 
Section of Cameo(?) coal in sec. 11, T. 8 S., R. 102W.

[Measured by G. B. Richardson (op. cit., p. 33)]

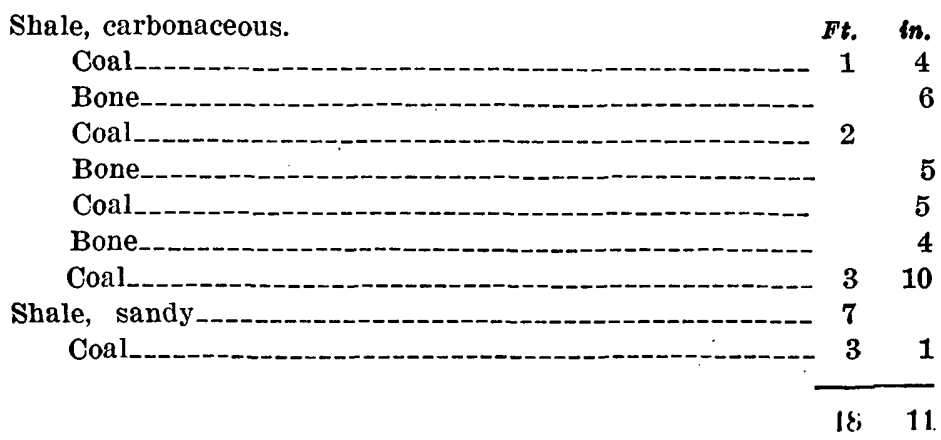

Along the front of the cliffs the Cameo coal is under 650 to 750 feet of cover. This increases by about 200 feet in the northern part of the township.

\section{CARBONERA COAL ZONE}

A thick massive clinker extends upstream above the Cameo coal along the canyon of Salt Wash and up Buniger Canyon to the vicinity of the Buniger mine, where the following section was measured :

\section{Section at Buniger mine}

Sandstone, gray, medium-grained

Coal, bituminous

Ft. In.

Shale, carbonaceous

3

Shale, sandy, buff to gray, irregularly bedded.

Sandstone, buff, massive, medium-grained

Sandstone, clayey, buff, thin irregular beds

Coal, bituminous, clean

Shale, carbonaceous

Sandstone, thin, platy layers

Sandstone, thin 8-inch beds, brown, medium fine grain, hard, concretionary in part.

Shale, gray, platy ; some layers concretionary------

Shale, carbonaceous

Coal, bituminous, clean; good cleavage S. $17^{\circ} \mathbf{E}$.,

N. $70^{\circ}$ E.; entry follows latter direction

Shale, carbonaceous

Coal (Carbonera?)

Base concealed. This bed is reported to have a 6

12

10

$11 / 2-3$

$81 / 2$

23

$\mathbf{8}$

110

63

$26-8$

total thickness of $7 \mathrm{feet}$, and the coal is said to burn cleanly, with little ash.

At locality B, 66 feet above the top of the Cameo coal, the base of another coal bed appears. It is probably to be correlated with the bed at the Buniger mine. The beds intervening between the two coals are as follows: 
Section of beds above Cameo coal at locality B, sec. 2, T. 8 S., R. 102 W.

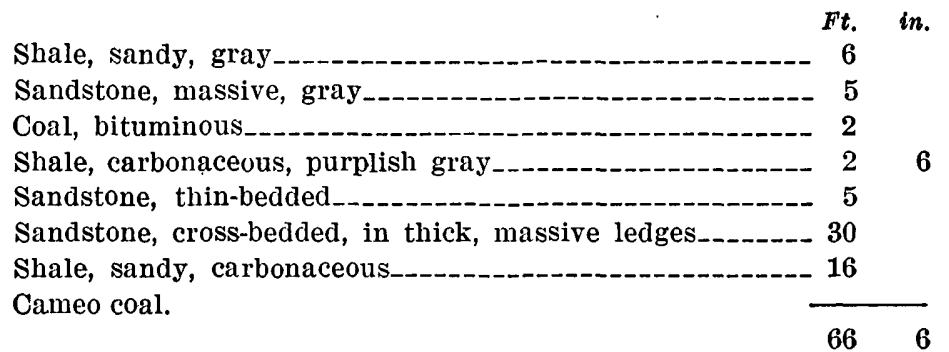

A section of this higher bed taken at locality $\mathrm{E}$, in sec. 2, is as follows:

Section of Carbonera(?) coal at locality E., sec. 2, T. 8 S., R. $102 \mathrm{~W}$.

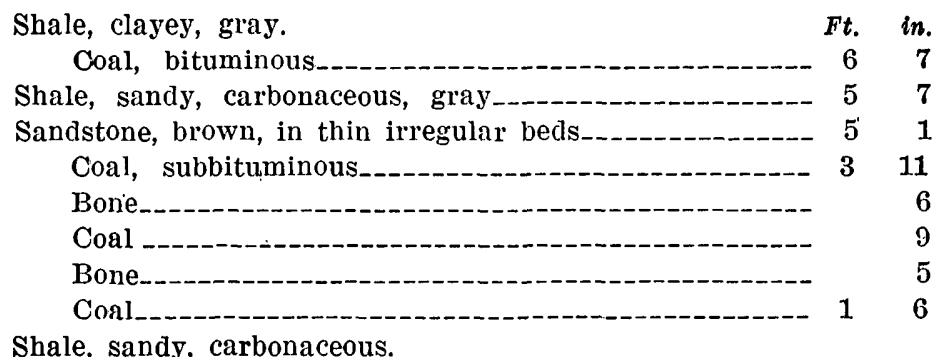

At locality F, a little farther west, the sandstone parting thickens, as shown by the section below. At this locality the base of the bed underlies the wash, which is floored with coal. The base of the bed appears about 200 feet downstream, but there the upper part is burned. The total thickness of this bed is estimated to be 10 feet.

Section of Carbonera(?) coal at locality F, sec. 2, T. 8 S., R. 102 W.

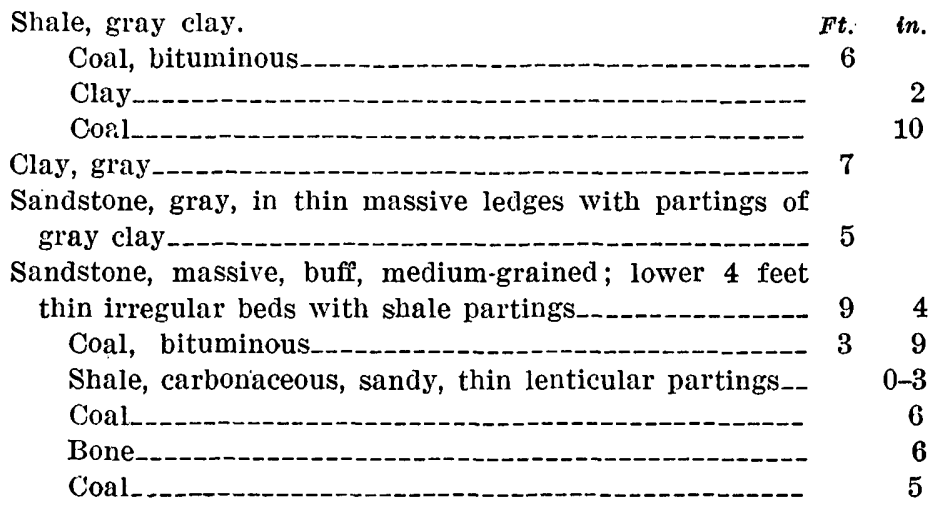

Shale, carbonaceous, bony

Sandstone. 
From the stratigraphic position of this upper bed with reference to the top of the Cameo coal it should be correlated with or at least considered essentially contemporaneous with the Carbonera coal zone. The presence of a bed of coal 66 feet above the Cameo at locality $\mathrm{B}$ and the presence of an ash bed 65 feet above the Cameo near locality 118 show correspondence to the Cameo-Carbonera interval of 62 to 70 feet in the West Salt Creek region. Direct correlation by continuous tracing cannot be made, as the ash bed disappears at the west line of sec. 3, indicating that the coal lenses out. However, the coals that occur above the Cameo zone at about the same intervals at locality 18 , in T. 7 S., R. 102 W., at localities 16 and 17, in T. 8 S., R. 103 W., and at locality 15, in T. 7 S., R. 104 W., may be considered to be at the same horizon.

The thick clinker from the burning of the Cameo and Carbonera coals extends southeastward into T. 8 S., R. 101 W., and the precise locality where the Carbonera coal lenses out to the southeast cannot be determined, but it certainly does not go so far as the locality of the Anchor no. 1 mine, in sec. 27 of that township.

The maximum amount of cover on this bed is 800 to 900 feet.

\section{T. 8 S., R. 103 W.}

In T. 8 S., R. 103 W., three coal beds or groups of beds crop out along the cliffs over a small area in the northern tier of sections. The lowest stratigraphically is a thin local bed in the Sego sandstone. The Palisade coal crops out just above the Sego sandstone. The Cameo coal lies about 200 feet above the Palisade.

No development work of any kind has been done on the coal beds in this township.

\section{LOCAL COAL BED IN SEGO SANDSTONE}

The thin bed in the Sego sandstone was noted only at locality 116, in sec. 6. It occurs at about the same stratigraphic horizon as the Anchor seam farther to the east, just below the upper member of the Sego sandstone, but observations along the face of the cliffs indicate that the two are in no way connected. The total thickness of the seam is 2 feet 5 inches, but it is split by a $31 / 2$-inch shale parting about 8 inches from the top. (See pl. 19.) The roof is a sandstone containing thin layers of clay shale. The floor consists of 2 feet of carbonaceous shale over a massive sandstone.

The thinness of the coal, the smallness of the lens, and the inaccessibility of the locality preclude any economic consideration of this bed. 
The Palisade coal crops out along the cliffs in secs. 2 to 6 , above - the cliff-making Sego sandstone. Five complete and three partial coal sections were measured on the bed. The upper seam of the bed at localities 79 to 81 , in sec. 2, contains coal of workable thickness.

c The maximum thickness measured at locality 81 is 5 feet 4 inches, with a 7 -inch shale parting 18 inches below the roof. At locality 80 there is 5 feet of clean coal. Elsewhere in this township the Palisade coal consists of an upper and a lower seam or group of thin over-

r lapping lentils of coal, separated by sandstones and sandy shales and enclosed in a thick bed of carbonaceous shale. The maximum cover over the workable beds probably does not exceed 600 feet.

\section{CaMeo coal}

Irregular areas of Cameo coal project southward into this township from the main area to the north. The aggregate area underlain by Cameo coal is not much more than half a square mile. The exposures are high on the cliffs and are covered by talus from the higher slopes, and about 75 percent of the outcrop is burned. Two coal sections were measured at localities 39 and 40 . Upper and lower seams are well defined at both localities. The interval between the seams is 22 to 25 feet. The roof of the workable seams is sandstone; the floor is carbonaceous shale. These localities can be easily reached from the Camp Canyon road.

The cover is slight over the Cameo outcrop in the northeast corner of sec. 3 and also in sec. 6 , where the coal is probably completely burned. It is thickest in the northeast corner of sec. 5 and the northwest corner of sec. 4 but probably does not exceed 400 feet. On the upper spur between secs. 3 and 4 it is moderate, probably not more than 300 feet.

T. 8 S., R. 104 W.

Three coals crop out in T. 8 S., R. $104 \mathrm{~W}$. The lowest is the Palisade, which appears just above the Sego sandstone; the Cameo zone is about 200 feet above it; and the base of the Carbonera zone is 45 or 50 feet higher. The outcrops are confined to small areas on the promontories of the Book Cliffs.

No development work of any kind has been done on the coal beds in this township.

\section{palisade Coal}

No coal sections could be measured on the Palisade zone in this township, as the outcrops are everywhere very inaccessible. Observations of the outcrops made with field glasses and the nature of 
the zone in the adjoining townships to the north and east give no reason to believe that workable coals exist at this horizon in this township. The coal is under slight cover, not exceeding 250 feet in thickness, and over most of the area it is less thąn 200 feet.

\section{CAMEO COAL zONE}

No sections of the Cameo zone could be measured in this township. The outcrops are higher on the cliffs than those of the Palisade zone. There is no reason to believe that the zone contains coal of economic value. The maximum amount of cover on the zone is not more than 125 feet, and over the greater part of the area it is very much less.

\section{CARBONERA COAL ZONE}

The burned outcrops of the lower Carbonera coals project southward into the northeast corner of sec. 6. No examinations or section of the coals could be made, on account of their inaccessibility. The area back of the outcrop in this township is under slight cover.

\section{T. 7 S., R. 102 W.}

The two coal beds that crop out in T. 7 S., R. 102 W., belong to the Palisade and Cameo zones, but only the Cameo coal is of economic importance. In sec. 30 the interval between the uppermost Palisade seam and the base of the Cameo zone, as determined by aneroid barometer, is 285 feet, but a local 19 -inch coal bed was noted 125 feet below the Cameo zone. A few thin seams of coal and some carbonaceous shale occur at the Carbonera horizon, but this coal zone is not well developed in the township.

\section{PALISADE COAL}

The Palisade coal zone consists of a series of three or four thin, overlapping lenses of coal in a thick bed of carbonaceous shale. Complete sections were obtained at localities 88 and 89 , in sec. 20 , and at locality A, 800 feet east and 1,300 feet south from the northwest corner of sec. 30. (See pl. 19.) The maximum thickness of clean coal is 2 feet.

Section of Palisade coal at locality A, sec. 30, T. 7 S., R. 102 W.

\begin{tabular}{|c|c|}
\hline hale, carbonaceous. & Ft. \\
\hline Coal, bituminous & \\
\hline Shale, carbonaceous & 1 \\
\hline Coal, bituminous- & \\
\hline Shale, sandy, carbonaceous-_. & 5 \\
\hline Coal_- & 1 \\
\hline Shale, sandy, carbonaceous & 1 \\
\hline
\end{tabular}




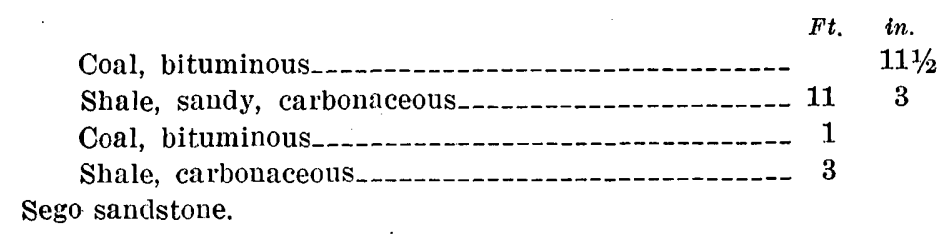

The beds are all more or less irregular and lenticular. About 200 feet along the outcrop to the northwest the 15-inch bed of shale thins, and the coal beds above and below come together to form a seam about 2 feet 2 inches thick. There is no indication that the bed is thicker, cleaner, or more suitable for prospecting at any other place.

\section{CAMEO COAL}

Six complete sections of the Cameo coal were obtained at localities 45 to 49 and locality B, which is 1,300 feet east and 450 feet south from the northwest corner of sec. 30 .

Section of Cameo coal at locality B, in sec. $30, T .7$ S., R. $102 \mathrm{~W}$.

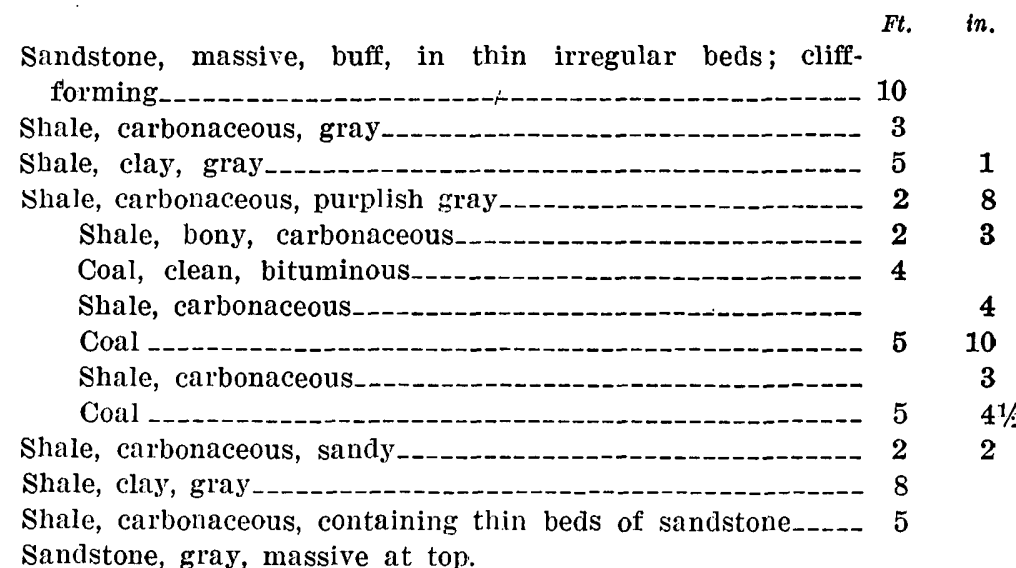

A small adit has been driven, about 10 feet into the base of the coal at locality 48 . Locality 49 is at an abandoned coal mine. The coal is thicker at localities 47 and 48 than at any other place examined west of the Book Cliff mine (locality 53a, T. 10 S., R. 99 W.).

At locality 47, in McLane Canyon, in sec. 21, the Cameo zone seems to lens out to the west, but this is only apparent, the Cameo having been dropped some 235 feet against the thinner coals of the upper part of the Palisade zone by a normal fault.

In this township, as in other places along the cliffs, the coal goes rapidly under thick cover. This is due principally to the steepness of the higher slopes, and in a less degree to structure. Within a distance of about $21 / 2$ miles back from the outcrop the cover is usually not less than 1,300 feet thick, except along the valley of East Salt 
Creek. The maximum cover in the township is in the northeastern part, where it is about 2,700 . feet.

CARBonera CoAL (?)

A thin seam of coal that may belong to the Carbonera zone occurs about 60 feet above the Cameo coal at locality 18, in sec. 20. It does not appear to exist on the east side of East Salt Creek, but the occurrence of beds at a similar horizon has been noted farther to the southeast. About 70 feet above the base of the Cameo coal at locality $\mathrm{B}$ there is a thick bed of carbonaceous shale, but no coal was observed.

\section{T. 7 S., R. 103 W.}

Three principal coal zones crop out in T. 7 S., R. 103 W. The lowest is the Palisade, which is just above the Sego sandstone; the Cameo zone lies about 200 feet above it; and in two localities a coal was noted above the Cameo. Although this upper bed has not been traced directly into the Carbonera coal zone near the town of Carbonera, it is believed to be a lens at about the same horizon and is therefore referred to by that name.

\section{PALIsade CoAL}

The Palisade coal zone was examined at 12 localities in the township. The outcrops are fairly good and are practically unburned. Measurements taken at localities 71 and 82 to 87 (see pl.20) are complete in that they include the whole thickness of the zone. Measurements at localities $66,69,70,77$, and 78 were made on only the thicker coal seams. It is apparent that the zone consists of at least two and more commonly three thin overlapping seams or lentils of coal in a thick bed of carbonaceous shale. The coal in these lenses is of low to medium bituminous rank and is of fairly good grade, but most of the seams are so thin as to be unworkable. The average thickness of 26 seams included in the 12 coal sections is 1 foot 3 inches; the maximum thickness is 3 feet 5 inches at locality 86 .

The roof and floor of the thickest seams are invariably carbonaceous shale. The coal is under moderate cover throughout the township, except for the outlier in secs. 26 and 35, where the cover is thin. In the area overlain by the Wasatch formation the maximum thickness of cover is at least 2,000 feet.

\section{CAMEO COAL}

The Cameo coal zone was examined at localities 37,38 , and 41 to 44. Only the measurements at localities 37 and 42 can be considered complete. These sections show, however, that the two seams, sepa- 
rated by a parting of carbonaceous shale as found in the townships to the southeast, persist into this township. The partial coal sections all represent the upper seam. The upper portion of the section at locality 43 has been burned. No fresh coal is exposed, as there has been considerable slacking on the outcrops.

The cover on the Cameo coal averages 200 feet less in thickness than that on the Palisade zone, the maximum being probably 1,800 feet. It is so thin on the long ridges in the western part of sec. 24 and in sec. 23 that any unburned underlying coal is probably worthless. The cover of the big outlier mostly in secs. 27 and 34 is estimated to be about 700 feet.

\section{Carbonera coat}

At localities 16 and 17 , in secs. 32 and 33 , respectively, thin seams of coal occur some distance above the horizon of the Cameo coal, the lowest being 50 feet above the top of the Cameo zone. Because of their stratigraphic position these beds are correlated with the Carbonera zone, although they have not been traced into it.

At locality 17 a bed of coal 5 feet 7 inches thick occurs, but it is broken by a 3-inch parting of carbonaceous shale 1 foot 7 inches above the base. This seam is about 41 feet above the top of the Cameo zone and occupies the same stratigraphic position as the lowest seam at locality 16. For this reason the two are correlated, though a direct connection by tracing has not been made. The outcrops are very inaccessible and can be reached only in canyons near the crossing of the beds. A more detailed study of this horizon in secs. 5 to 8 is warranted.

\section{T. 7 S., R. 104 W.}

Three coal zones crop out in T. 7 S., R. 104 W. (See pl. 21.) The lowest is the Palisade, which is just above the Sego sandstone; the Cameo zone is about 200 feet above the Palisade; and 50 feet or more above the Cameo is the base of the Carbonera zone.

The Carbonera mine is the only mine that has been opened in the township, except the abandoned prospect just across the canyon. The coal is mined for fuel for the Uintah Railway; and a small amount is supplied to the railroad employees.

\section{palisade coat}

The outcrops of the Palisade coal are so inaccessible that.a detailed examination could be made at only a few localities, but eight sections were obtained. The nature of the bed wherever examined suggests that no coal of value at the present time occurs at this horizon. A similarity was noted between the sections at locality A, 
1,800 feet east and 400 feet north of the southeast corner of sec. 29 , and at locality C, 1,350 feet west and 300 feet north from the southeast corner of sec. 21, where the Palisade coal zone crosses the canyon, which suggests that the 25-foot bed of carbonaceous shale resting on the Sego sandstone at locality $\mathrm{C}$ has lensed out toward locality A.

Section of Palisade coal at locality A, sec. 2S, T. 7 S., R. 104 W.

\begin{tabular}{|c|c|}
\hline hale, carbonaceous. & Ft. \\
\hline Coal, bituminous & 2 \\
\hline Shale, carbonaceous, sandy & 4 \\
\hline Shale, carbonaceous & 1 \\
\hline Coal, bituminouss & 2 \\
\hline Shale, carbonaceous & 2 \\
\hline
\end{tabular}

Section of Palisade coal at locality $C$, in sec. 21, T. 7 S., R. 104 W.

Bituminous coal, clean

Shale, carbonaceous_._. 10

Coal _._-_._._. 13

Shale, carbonaceous, sandy

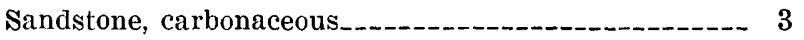

Shale, carbonaceous

Coal, bony

Shale, carbonaceous._.

Sego sandstone.

LOCAL BEDS

About 125 feet above the base of the Palisade coal zone a local bed occurs. The accompanying section was measured where it crosses the canyon between localities $\mathrm{C}$ and $\mathrm{D}$, in sec. 21 .

Section of local coal bed between localities $C$ and $D$, in sec. 21, T. 7 S., $R .104 W$.

Sancistone, thin-bedded; grades upward into massive

Ft. in.

sandstone; less than

Shale, carbonaceous

Bituminous coal, clean

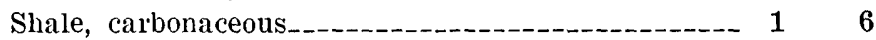

Sandstone, massive, gray, medium-grained, slightly carbonaceous

Shale, carbonaceous

Bituminous coal, clean

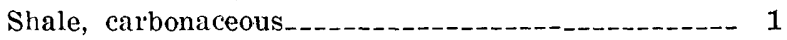

Carbonaceous shale and sandstone in thin alternating beds. 


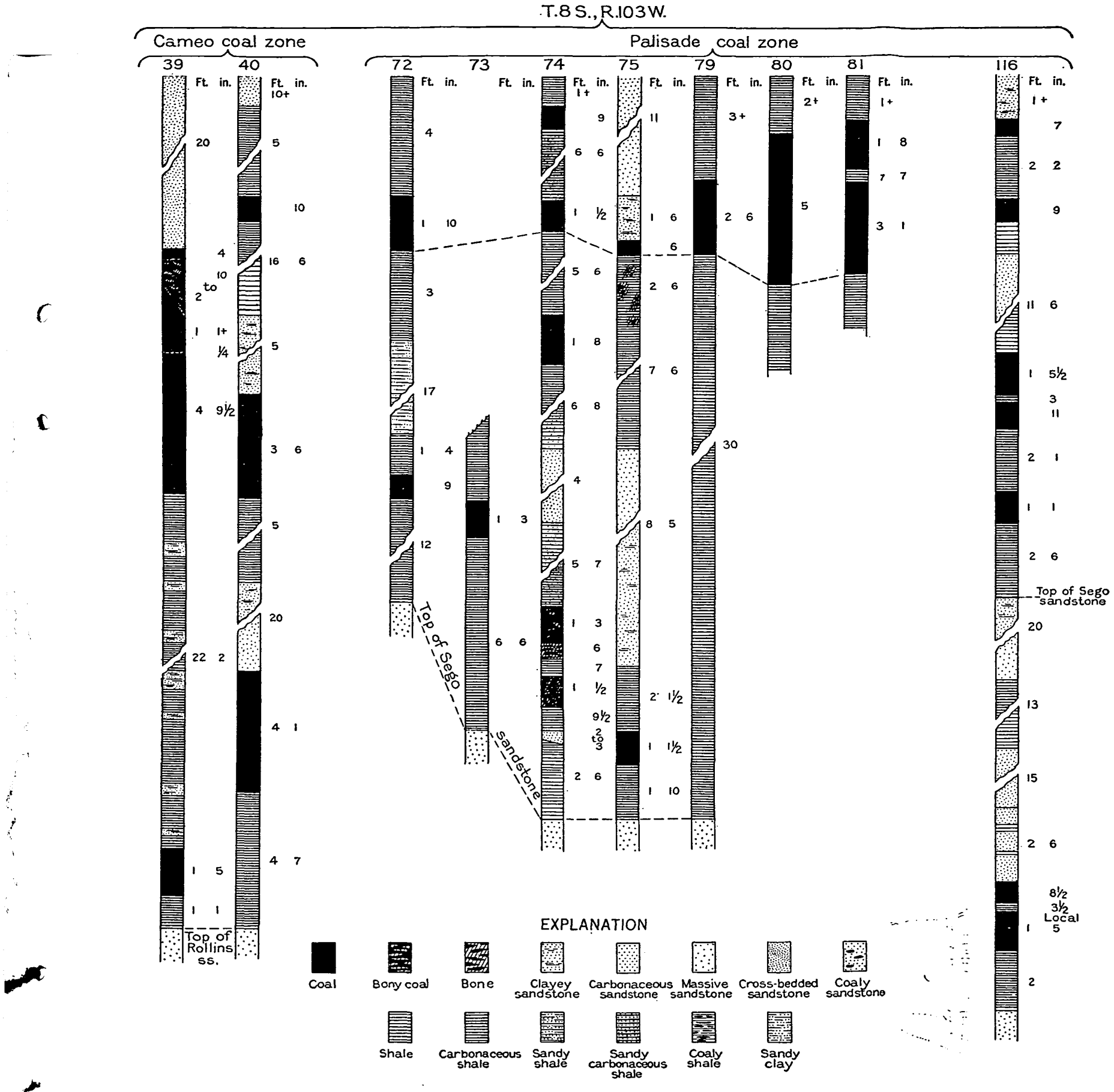

T.7 S. , R.102W.

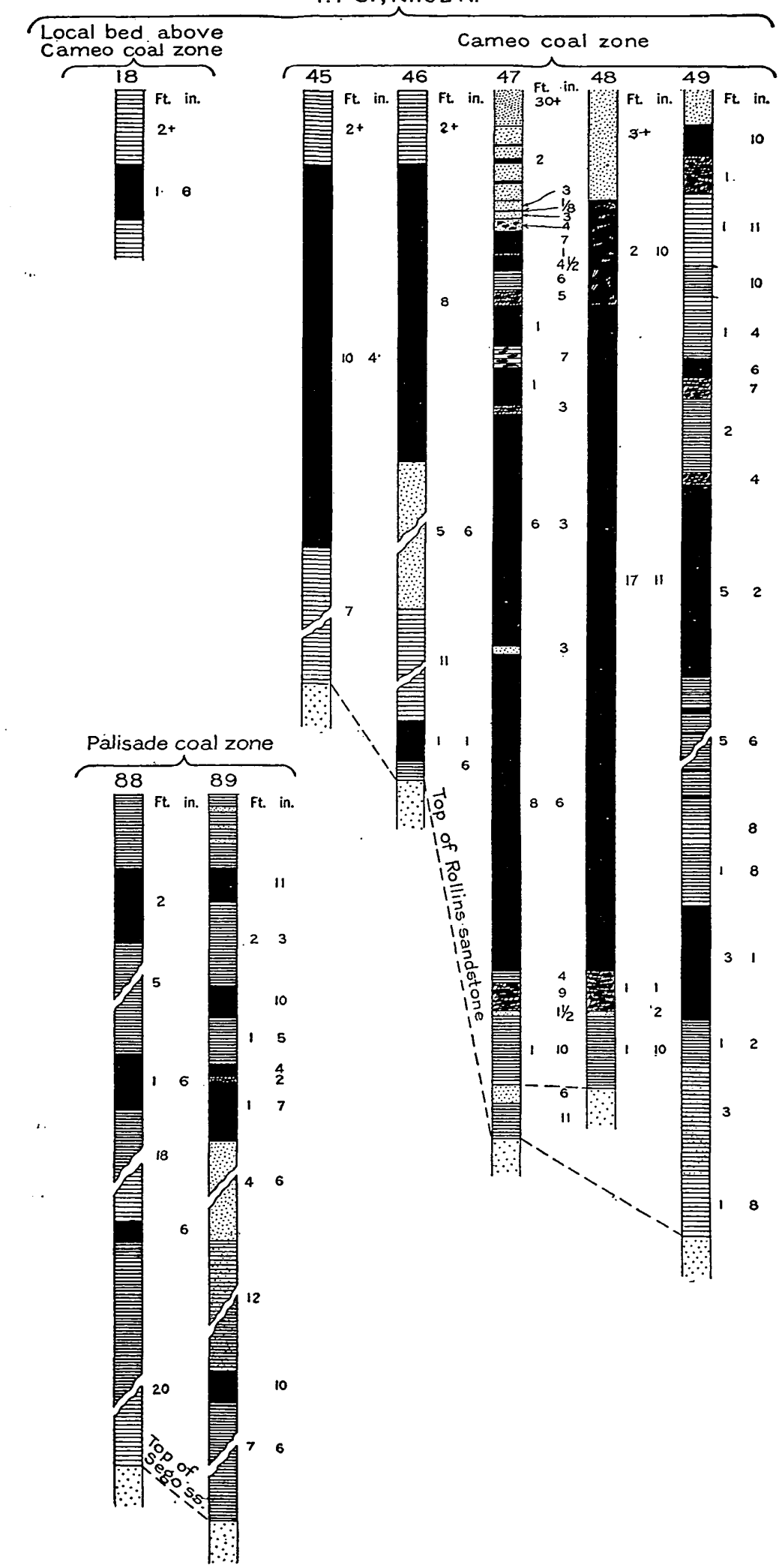

SECTIONS OF PRINCIPAL COALS EXPOSED IN T. 8 S., R. 103 W., AND T. 7 S., R. 102 W. 

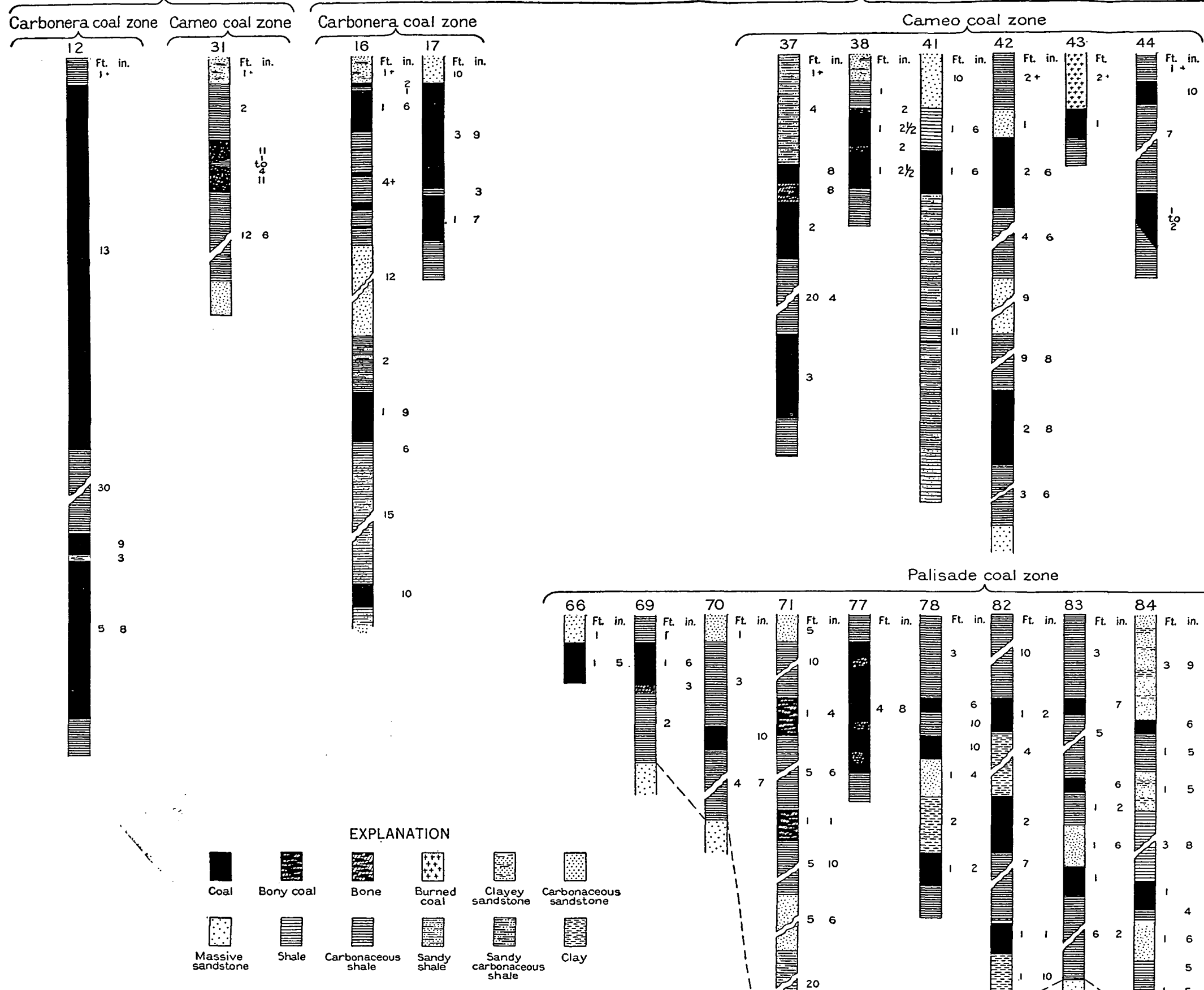

Palisade coal zone
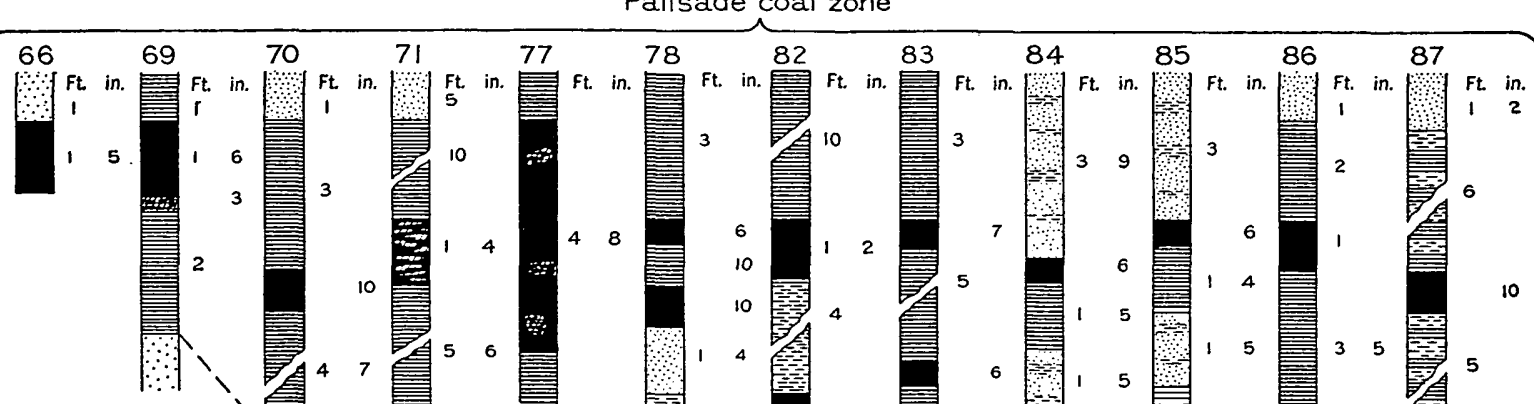

I

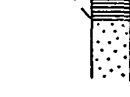




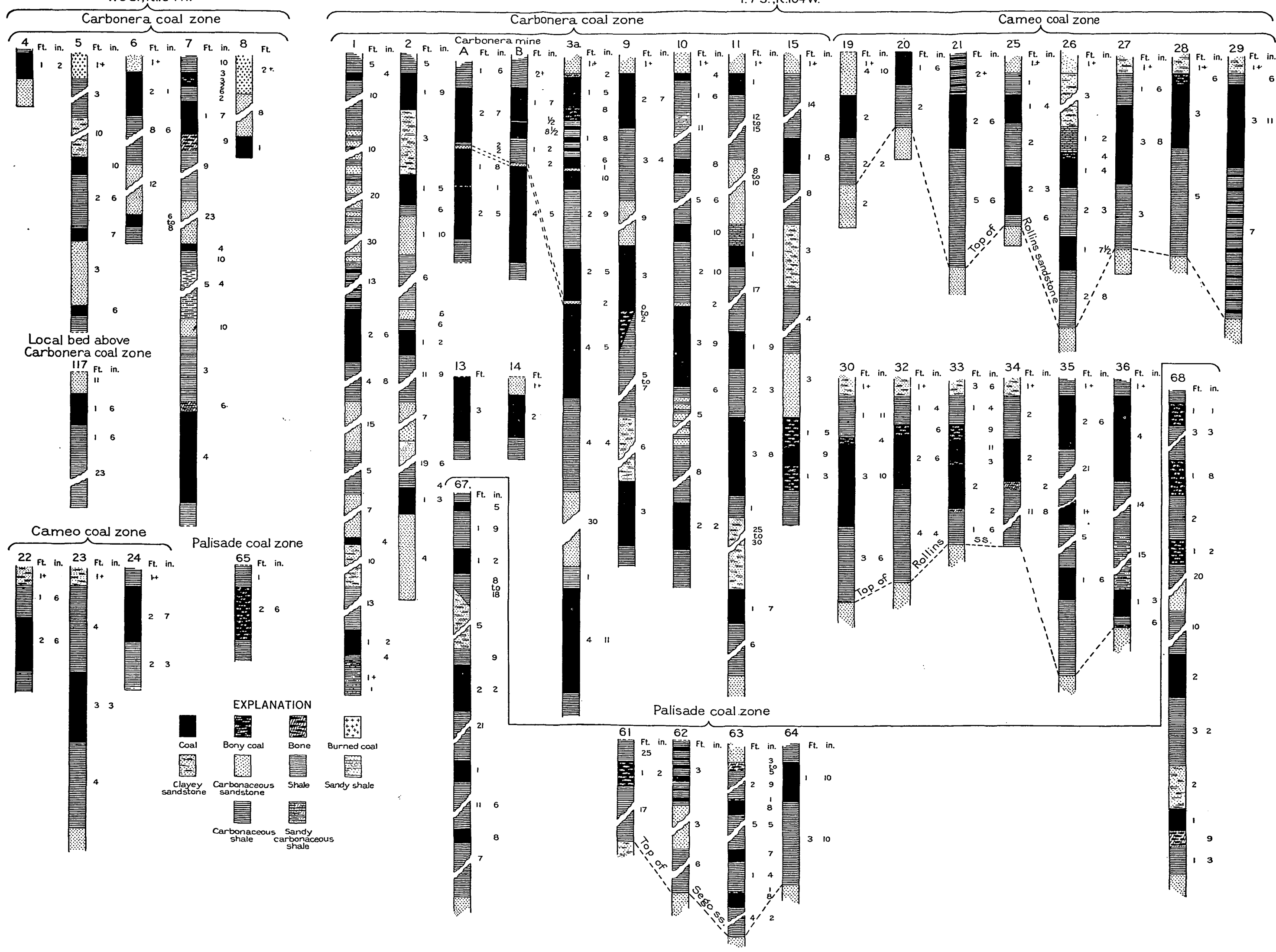

SECTIONS OF PRINCIPAL COALS EXPOSED IN TPS. 6 AND 7 S., R. 104 W. 
In sec. 29 at a corresponding horizon there is a 10 -foot zone of carbonaceous shale with a 5 -inch coal seam at the top and an 11-inch seam at the base.

Although tentatively assigned to the Cameo(?), the bed at locality 19 may belong to this group.

\section{CAMEO COAL}

In this township 15 measurements of the Cameo zone were made. A section in Prairie Canyon shows but 1 foot 3 inches of coal. Where the zone crosses the canyon, in the southwestern part of sec. 29 , there are four beds of coal, ranging in thickness from 3 to 8 inches, in a zone of carbonaceous shale and sandstone 20 feet thick. At locality $\mathrm{D}$, in sec. 21 , the zone consists chiefly of carbonaceous shale and contains one 12-inch bed of good clean bituminous coal. The indications are that the Cameo thins rapidly west of the center of the township, and it cannot be traced with certainty west of the State line. At locality 21, in sec. 3, there is 2 feet 6 inches of clean coal in a thick bed of carbonaceous shale. North of this place the seam thickens and becomes of workable thickness at locality 23 , in sec. 23 , T. 6 S., R. 104 W. At localities 20, 25, and 26, in the canyon of West Salt Creek, the coal is too thin to work, but beginning in sec. 13 and the eastern part of sec. 14, near the mouth of South Canyon, it is thicker. Over about 3 square miles in these sections the coal has an average thickness of 3 feet 8 inches. In this vicinity the Cameo coal appears only as a single seam in a bed of carbonaceous shale. The roof is of "draw slate" 1 to 2 feet thick, overlain by soft sandstone and sandy shale. The floor is carbonaceous shale and at some places is covered by a thin layer of bone. This shale is underlain by a strong massive sandstone.

The cover on the Cameo crial thickens rapidly back from the outcrops. Along the front of the cliffs it probably averages 500 feet, and it increases northward to a maximum of about 1,850 feet.

\section{CARbonera COAL}

The Carbonera coal zone is of considerable local importance in this township, though as a whole it is less well defined than the Palisade and Cameo zones. It consists of two or usually three lenticular and overlapping seams of coal. The base of the lowest seam is 40 to 60 feet stratigraphically above the Cameo coal.

Fourteen coal sections were measured, of which seven are complete. Those at localities 1 and 2 are in Prairie Canyon. They contain no workable seams and serve only to illustrate the westward thin50646-34- -10 
ning of the coals of the zone. This thinning apparently begins a short distance south of the town of Carbonera, as is illustrated by the character of the beds at locality $\mathrm{E}$, in sec. 21 . The lowest Carbonera seam occurs about 70 feet above the Cameo zone, and this interval corresponds to the Cameo-Carbonera interval elsewhere in the region.

Section of lowest seam of Carbonera coal at locality $E$, in $\$ E 1 / 4 \$ W 1 / 4$ sec. 21, T. 7 S., R. $104 \mathrm{~W}$.

$\begin{array}{lrr}\text { Sandstone, buff. } & \text { Ft. } & \text { in. } \\ \text { Shale, carbonaceous. } & 1 & 6 \\ \quad \text { Bituminous coal, clean } & 2 & 6 \\ \text { Shale, carbonaceous. } & & \end{array}$

The highest Carbonera coal seam occurs about 40 feet above the lowest and 110 feet above the Cameo. The following section was measured where it crosses the canyon:

Section of highest seam of Carbonera coal at locality $E$, in seo. 21, T. 7 S., R. $104 \mathrm{~W}$.

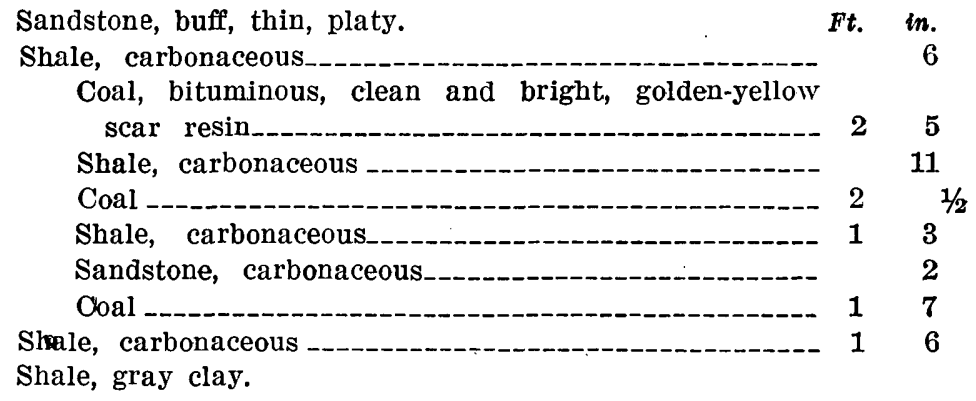

The coal exposed at locality $\mathrm{B}$, in sec. 28 , belongs to the Carbonera zone and is probably the highest bed in that zone.

Section of highest seam of Carbonera coal in sec. 29, T. 7 S., R. $104 W$.

Sandstone, massive, buff, thinly laminated at base.

Ft. in.

Coal, bituminous, clean, black

4

6

Coal, like above, but weathers rusty

Coal, bituminous

19

Shale, carbonaceous.

Two coal sections were measured at the Carbonera mine of the Gilson Asphaltum Co. Section A was taken at the working face on the first rise 1,400 feet from the main entry; section B was measured on the outcrop at the portal of the main entry.

Richardson gives three sections from this mine. 
Sections of Carbonera coal at Carbonera mine

[Measured by G. B. Richardson (op. cit., p. 36)]

\begin{tabular}{|c|c|c|c|}
\hline & $\underset{\text { entry }}{\text { End of back }}$ & Room 3 & $\underset{\text { entrance }}{\text { Near }}$ \\
\hline \multirow[t]{2}{*}{$\begin{array}{l}\text { Coal } \\
\text { Bone } \\
\text { Coal } \\
\text { Bone } \\
\text { Coal }\end{array}$} & $\begin{array}{cc}\text { Ft. } & \text { in. } \\
2 & 1 \\
& 1 \\
& 101 / 2 \\
& 5 \\
4 & \end{array}$ & $\begin{array}{cr}\text { Ft. } & \text { in. } \\
1 & 10 \\
1 & 1 \\
1 & 1 \\
3 & 6\end{array}$ & $\begin{array}{rr}\text { Ft, in. } \\
2 & 1 \\
2 & 8 \\
& 4 \\
4 & 3\end{array}$ \\
\hline & $51 / 2$ & & 7 \\
\hline
\end{tabular}

The carbonaceous sandstone parting indicated in plate 21 is persistent throughout the mine and ranges in thickness from 2 inches to 18 inches where carbonaceous shale is included. It is mined out and hand-picked from the coal on the car. All workings are in the middle seam. The mine workings are cut by a zone of "step" faults. The maximum throw is about 14 feet, but the throw of any single fault does not exceed 2 feet. The faulting is important economically in that it has dislocated the coal bed and caused a zone of weakness which requires careful watching to prevent the development of a "squeeze." Heavy timbering is required in the faulted zone and above other permanent openings in the mine. The strike of this fault zone is essentially the same as that of the other faults in the township. The dips, however, are less.

Across the creek at locality 9 there is an abandoned entry into the middle seam. This old mine has not been worked for many years. There is also a good exposure of the Carbonera zone in sec. 13 at locality $3 \mathrm{a}$. There the strata have been raised by the Garmesa anticline and stand high above the creek. They are affected by the steep dip of the south limb of the fold, so that the locality is unsuitable for mining.

The following complete section of the zone, whose exact location cannot be determined, was measured by Richardson ${ }^{88}$ near Carbonera :

\section{Section near Carbonera}

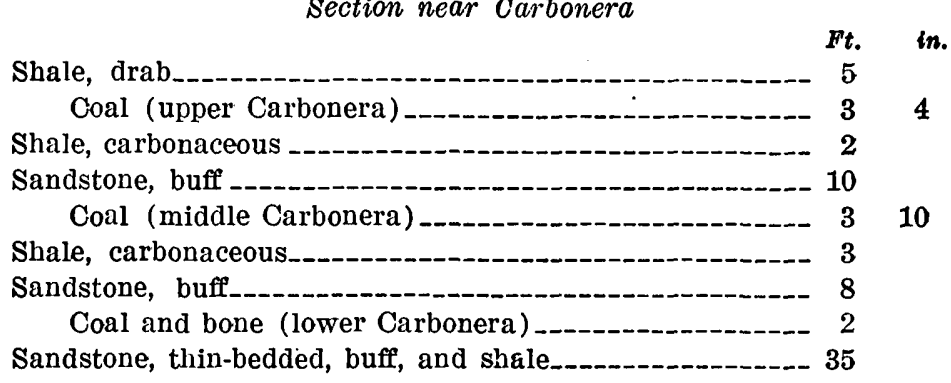

${ }^{88}$ Richardson, G. B., op. cit., p. 35. 
At locality 10, on the north wall of West Salt Creek Canyon in sec. 14, only the middle seam is workable. The upper bench described by Richardson has split up into a number of thinner seams which are contained in a bed of carbonaceous shale. The middle seam maintains its tenor. It continues so at locality 11 , but both the upper and lower seams and their respective intervals from the middle bench vary widely. Two partial sections of the Carbonera zone, probably the lower bench, were measured at localities 13 and 14 in sec. 13.

The cover on the Carbonera zone between Prairie Creek and West Salt Creek increases rapidly from the outcrop to a maximum thickness of 1,200 feet or more in the northwest corner of sec. 21 and in sec. 16. The cover on the Carbonera mine is 800 to 900 feet. In the part of the township overlain by the Wasatch formation the thickness of the cover is greatest and ranges from 1,000 to 1,500 feet.

T. 6 S., R. 103 w.

Two coal zones crop out in T. 6 S., R. $103 \mathrm{~W}$. The lower one is the Cameo, and about 40 to 50 feet above it is the base of the Carbonera zone. The outcrop areas of these beds are small, as they appear only where they cross the larger canyons.

There has been but little prospecting and no development of the coal beds in this township, because of the inaccessibility of the coal outcrop.

\section{CAMEO COAL}

One section of the Cameo coal was measured at locality 31, in sec. 31. (See pl. 20.) The bed is thin, and the coal is bony. The outcrops were concealed under a heavy bed of talus and alluvium in sec. 32 .

\section{CARBonera coal}

The coals of the Carbonera zone crop out in secs. 18, 19, 31, and 32. Outcrops are rare, but one good section was observed at locality 12 , in the SE $1 / 4$ sec. 31, T. 6 S., R. 103 W. Here a 13-foot bed of coal is separated from a 7-foot bed by 30 feet of carbonaceous shale. The lower, thinner bed has a 3 -inch sandstone and shale parting 9 inches from the top. The bed is broken by a small normal fault, and the portion on the upthrown side is burned. Much of the coal along the outcrop in sec. 32 is also burned. A nearby section is that at locality 7, in T. 6 S., R. 104 W., where 3 feet 11 inches of coal is exposed in the middle of the seam.

The Carbonera zone is under thick cover in this township. Except where the cover has been locally removed, it probably averages 
about 1,000 feet in the southern part and increases to nearly 2,00() feet in the areas overlain by the Green River formation.

\section{T. 6 S., R. 104 W.}

Three coal zones crop out in T. 6 S., R. 104 W. The lowest is the Palisade, which occurs just above the Sego sandstone; the Cameo zone is about 200 feet above it; and 40 to 50 feet above the Cameo is the base of the Carbonera zone. The only area of exposure is in the southeast quarter of the township, where West Salt Creek has cut through the Garmesa anticline. No development work has been done on the coals in this township.

\section{Palrsade CoAL}

The only measurement of the Palisade zone made in this township was at locality 65 , in sec. 34, where 2 feet 6 inches of shaly coal is exposed. (See pl. 21.) The coal was carefully traced, in the hope that a workable lentil might be found. In sec. 36 , on the blunt nose between the forks of the big eastern tributary to West Salt Creek, there is a zone of carbonaceous shale but no coal at the Palisade horizon. No coal is present at this horizon on the long spur which terminates about 1,000 feet north of the southeast corner of sec. 26. At the top of the shale zone above the Sego sandstone there is a layer of dark-brown to nearly black carbonaceous shale, which contains thin seamlets of coal and some mineral charcoal. Near the center of sec. 25, where the Palisade zone crosses the wash, a similar condition exists.

It may be concluded that the coals of the Palisade zone, which have been thinning and decreasing in value northwestward for the last 20 miles or more, finally lens out in the southeast quarter of this township.

\section{CAMEO COAL}

Two sections of the Cameo coal were measured at localities 22 and 23 , in secs. 34 and 23 , respectively. The coal at locality 22 is 2 feet 6 inches thick, has a platy structure, and is enclosed in a bed of carbonaceous shale. The section at locality 23 shows the thickest Cameo coal found in the township. The enclosing beds of carbonaceous shale and the massive sandstone below the shale are similar to those of the Cameo zone in South Canyon, in T. 7 S., R. $104 \mathrm{~W}$.

The coal at locality 24 is regarded as Cameo, although the interval between the base of the Carbonera zone and the top of the Cameo zone here is only 16 feet. The interval is about half that usually considered the minimum between the Cameo and basal Carbonera coals. 
It is possible, therefore, that the coal here called Cameo may be the lowest Carbonera seam.

\section{CARBONERA COAI}

The exposures of the Carbonera zone are not only inaccessible but are covered with talus and are locally burned. Five coal sections were obtained. That at locality 4 shows the amount of coal in this zone at the head of the big gulch in sec. 27 . The section at locality 5 shows the lower portion of the zone; the heavy burn at its top indicates that the thickest bed has burned out. The same is true at locality 8 , in sec. 25. At locality 6 , in the southeast corner of sec. 23, 2 feet 1 inch of coal crops out. More detailed study in this region might show that this seam is somewhat thicker elsewhere.

The basal part of the section at locality 7 shows the thickest seam of coal so far discovered in this township. It is favorably located with respect to the road and railroad, but under present conditions it could not compete with the beds now mined at Carbonera. About 90 feet above the uppermost Carbonera seam, at locality 117, there is a local bed that shows 18 inches of coal.

The cover increases in thickness rapidly toward the northwest. The minimum cover under the base of the Wasatch is about 1,300 feet, and that under the base of the Green River formation probably does not greatly exceed 2,000 feet. Back of the Roan Cliffs the cover again increases abruptly, the maximum being about 3,000 feet.

\section{TPS. 7 AND 8 S., R. 105 W.}

Three coals crop out in Tps. 7 and 8 S., R. 105 W. The lowest is the Palisade, which is exposed just above the Sego sandstone; the Cameo is about 200 feet above it; and the base of the Carbonera zone is 45 or 50 feet higher. The area of outcrop is restricted to the southern part of T. 7 S., and the northern part of T. 8 S.

No development work of any kind has been done on the coal beds in these townships.

\section{PALISAde COAL zONE}

No coal sections were measured on the Palisade zone in this area, as the outcrops are everywhere very inaccessible. From observations of the outcrops made by the use of field glasses and from analogy with those in the townships adjoining on the east, there is no reason to believe that persistent coals of workable thickness occur at this horizon. In T. $8 \mathrm{~S}$. the beds are under light cover; the maximum does not exceed 300 feet and this only over small areas. In T. 7 S. the cover is thicker. 
Cameo coar zone

The principal Cameo outcrops in this area are in sec. 1, T. $8 \mathrm{~S}$, and secs. 25 and 36, T. 7 S. No coal sections were measured. The Cameo coal zone appears to lens out in the neighborhood of the State line, and consequently the coals are believed to be too thin to be of value. The cover is about 200 feet less than that over the Palisade coal.

CARBONERA COAI ZONE

The principal outcrop of the Carbonera zone is in the southern part of T. $7 \mathrm{~S}$. No coal sections were obtained from this zone in Colorado, but the beds were examined in Utah where they cross small canyons tributary to Prairie Canyon. No workable coals were found.

The minimum cover above the Carbonera outcrop is 300 feet. The maximum is in the area overlain by the Wasatch in the northern part of the township and probably does not exceed 2,000 feet. 
1 


\section{INDEX}

\section{$\mathbf{A}$}

Aberdeen sandstone member of Blackhawk formation, occurience of, in eastern Utah

Abstract of report

Accessibility of field

Acknowledgments for aid

Alluvium, occurrence and character of

thickness of

Anchor"coal, estimated available tonnage of

outcrop of

sections of

suggestions for prospecting for-

Anchor coal zone, general features tongue of Mancos shale,

Anchor Mine tongue of Mancos shale,
occurrence and character of

relations 0

B

Blackhawk formation, occurrence of, in eastern Utah

Book Cliff mine, section of Mount Garfield formation at $45-48$,

Book Cliffs, plateau between Roan Cliffs and...... 15-16

surface features of _._-__-_-_-- 14-15

uses of term

Book Cliffs dome, natural gas on

Bowie shale member of Mesaverde formation, occurrence of, in $\mathrm{G} r$ and Mesa region...-...--

relations of Mount Garfield formation to

Boyer mine, analysis of coal from.--

Buck tongue of Mancos shale, character and thickness of occurrence of, in Utab...-...

Buniger mine, analysis of coal from.

\section{C}

Cameo coal, estimated available tonnage of .......-

sections of

$113,116,117,123,128,129,131,135$ outcrop of, in McLane Canyon - pl.14

Cameo coal (?), section of _._-_-_ 130

Cameo coal zone, faults in general features of suggestions for prospecting-- 108-109

Dakota (?) sandstone, age of ------ 27-28 character and thickness of -...- 23, 27

coal and natural gas in possible occurrence of petroleum in -

Cameo mine, analysis of coal from

Camp Canyon dome, drilling for gas on

Carbonera coal, estimated available tonnage of sections of _._._._._. 130, 140, 141

Carbonera (?) coal, sections of.-- 126, 131

Carbonera coal zone, faults in__._-_ 69 general features of suggestions for prospecting--- 109

Carbonera dome, drilling for gas on _ 72-73

Carbonera mine, analysis of coal from.

Castlegate sandstone member of Price River formation, occurrence of, in eastern Utah_-_._._._._-_._. 31

Chinle formation, character and thickness of

Clark, F. R., quoted___-___-_ 88

Climate, general features of -..-_- 19

Coal, analyses of samples of, from Book Cliffs fleld_..._ 89-90 chemical composition of --_-_-- 88-92 conditions of deposition of .-.- 79-80 production of _-__________- 99-107 quantity of reserves of _._._._. 92-99

Coal beds, burning of -_-_-_-_._- $86-88$

Coal deposits, occurrence of _-_._-_ 76-80

Coal production, comparative statistics of (-. pl. 6

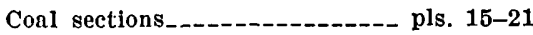

Coal zones, diagrammatic sections of - pl. 5 general features of names and intervals of _....... 78 relations of, to sandstones_-_-- $\quad 78$

Cretaceous rocks, occurrence and character of -.----- 27-53

Cretaceous(?) rocks, occurrence and character of _...-...-...- 26-27

\section{D}

Douglas Creek member of Green River formation, occurrence and character of

thickness of

Drainage, general fentures of _._._- 16-17

Dutton, C. E., quoted_._. 61 
E

East Salt Creek, section of lower member of Sego sandstone at

East Salt Wash Canyon, section of Anchor Mine tongue of Mancos shale in

Entrada sandstone, occurrence and character of ......-_ 24, 25

thickness of -

Eocene (?) rocks, character and thickness of -

Extent of fleld $1-3$

\section{F}

Farmers mine, analysis of coal from 89

Faults, occurrence and character of _ 68-69

Field work

Folds, occurrence and features of

\section{G}

Garmesa anticline, general features of --.----

Garmesa dome, analysis of natural gas from

gas wells on

Gas. See Natural gas.

Gas sands, correlation of-

Gearhart prospect, analysis of coal from

Geologic map and structure sections of Book Cliffs coal field in Colorado_- pl. 1 (in pocket)

Geologic work, account of previous--

Geomorphology

5-7

Grand Junction, Colo., meteorologic data for

Grand Valley, Book Cliffs on north wall of

pls. 23

general features of

Guand Valley irrigation project, water supply of

Green River formation, Douglas Creek member of, character and thickness of occurrence and character of --- 57-59 outcrop of, at head of Hunter Canyon

H

Fidden Treasure mine, analyses of coal from--_-

High Line dome, general features of Hunter Canyon, profle of Book Cliffs east of mouth of -

section of Anchor Mine tongue of Mancos shale at__._ 36-37 view northward up
Hunter Canyon formation, character and thickness of massive sandstone of _.......- pl. 8 occurrence and character of --_- 48-51 relations of _._-_-_-_-_-_-_- 33 type section of, in Hunter Canyon _... 51-53.

I

Industries and population of the area

$\mathbf{J}$

Jurassic (?) and Jurassic rocks, occurrence and character

K

Kayenta formation, character and thickness of -..---.--

Kayenta (?) formation, occurrence of -

L

Lakes, Arthur, quoted_-_..-_-_-_-

Land surveys, condition of

Location of field_.............. 1-3

\section{$\mathbf{M}$}

Mancos shale, age of

Anchor Mine tongue of, occurrence and character of _-

Buck tongue of, character and thickness of .

character and thickness of _-_-_ $\quad 23$ gradational boundaries of occurrence and character of.--- 28-30 terrace carved on

thickness of _._._._._._._._. 28

McGinley mine, analysis of coal from

Mesaverde formation of Grand Mesa region, relations of Mount Garfield formation to

subdivisions of

Mesaverde group, character and thickness of formations of general relations of

thickness of strata of Mining, development of -..-- 99-101

Monoclines, occurrence and features of -_-

Morrison formation, character and thickness of --_--- 24, 26-27

Mount Garfield, profile of Book Cliffs on._._._._. pl. 2 section of upper member of Sego sandstone at_-_._- $\mathbf{3 9}$ 
Mount Garfleld formation, "barren measures" in

character and thickness of.....-

"coal measures" of

general features of

ratio of coal to rock in coal measures of

relations of

to Bowie and Paonia shale members of Grand Mesa field _........_-_ 44-45

type section of

\section{$\mathrm{N}$}

Natural gas, character of ----_--- 74-76 development of

production of

$\mathbf{P}$

Palisade coal, estimated available tonnage of ........ sections of

$114,118,120,122,134-135,138$

Palisade coal zone, general features of _

suggestions for prospecting---- 108

Paonia shale member of Mesaverde formation of Grand Mesa region, relations of Mount Garfield formation to

Peacock mine, analysis of coal from. Population of the area, distribution of -....

Pre-Cambrian rocks, character and occurrence of

Price River formation, occurrence of, in eastern Utah -31

Prospecting for coal, suggestions for

\section{Q}

Quaternary deposits, occurrence and character of 59-60

\section{$\mathbf{R}$}

Richardson, G. B., quoted___._. 112-113

Roan Cliffs, general features of -.--

plateau between Book Cliffs and -..-- 15-16

Roan Plateau, general features of --

Rollins sandstone member of Mesaverde formation, occurrence of, in Grand Mesa region_.......

Rollins sandstone member of Mount Garfleld formation, occurrence and character of
$\mathbf{S}$

Sego sandstone, character and thickness of -.-....-.

lower member of, occurrence and character of -.-_ 35-36

occurrence of, on east wall of mouth of East Salt Creek Canyon_....... pl. 6

relations of upper member of, occurrence and character of

Service mine, analysis of coul from $\quad 89$

Star Point sandstone, occurrence of, in eastern Utah_._._- $\mathbf{3 1}$

Stove Canyon mine, analyses of coal from_- 89

Stratigraphy, general features of pls. 4, 5

Structure, contour map showing -- pl. 11 history of development of _-- 62-64 local features of regional setting of representation of -_._-_-_._-_- 64-65

Summerville formation, character and thickness of _._-_ 24, 26

\section{$\mathbf{T}$}

Terrace gravel, occurrence and character of

Terraces at foot of Book Cliffs_.-- pl. 3 Tertiary rocks, occurrence and character of

Tertiary (?) sandstone, erosional unconformity and con. glomerate at base of-- pl. 9 occurrence and character of_22, 53-55 outcrop of, at head of Hunter Canyon_..._........ pl. 10

Township descriptions :

T. 1 N., R. 1 E._-_ 117-120, pl. 15

T. 6 S., R. $103 \mathrm{~W}_{-}-142-143$, pl. 20

T. 6 S., R. 104 W._- 143-144, pl. 21

T. 7 S., R. 102 W._- 134-136, pl. 19

T. 7 S., R. 103 W--_- 136-137, pl. 20

T. 7 S., R. 104 W

Tps. 7 and 8 S., R. 105 W.- 144-145

T. 8 S., R. $101 \mathrm{~W}$-_- $124-127$, pl. 18

T. 8 S., R. 102 W.-- 127-132, pl. 18

T. 8 S., R. 103 W-_-- 132-133, pl. 19

T. 8 S., R. 104 W._._ 133-134

T. 9 S., R. 100 W._._._. 121-124

T. 9 S., R. $100 \mathrm{~W}$-._ $121-124$, pl. 17

T. 9 S., R. $101 \mathrm{~W}$

T. 10 S., R. 98 W._._._ 112-113

T. 10 S., R. 99 W

T. 10 S., R. 100 W - 120-121, pl. 16

T. 11 S., R. $99 \mathrm{~W}$-_- $111-112$, pl. 16

T. 11 S., R. 98 W.--- 109-111, pl. 15

Triassic rocks, occurrence and character of 


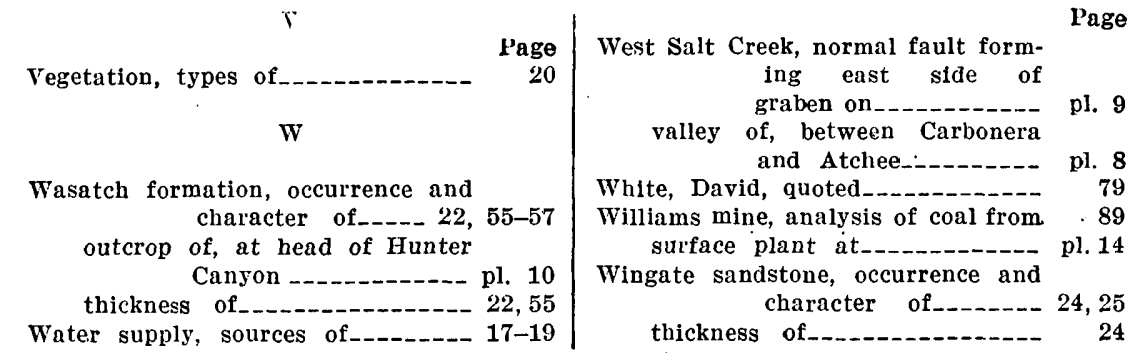

